Romel Dias Vanderlei

\title{
ANÁLISE EXPERIMENTAL DO CONCRETO DE PÓS REATIVOS: DOSAGEM E PROPRIEDADES MECÂNICAS
}

Tese apresentada à Escola de Engenharia de São Carlos da Universidade de São Paulo, como parte dos requisitos para obtenção do Título de Doutor em Engenharia de Estruturas.

Orientador: José Samuel Giongo 
Ficha catalográfica preparada pela Seção de Tratamento da Informação do Serviço de Biblioteca - EESC/USP

Vanderlei, Romel Dias
Análise experimental do concreto de pós reativos:
dosagem e propriedades mecânicas / Romel Dias Vanderlei.
-- São Carlos, 2004.
Tese (Doutorado) -- Escola de Engenharia de São
Carlos-Universidade de São Paulo, 2004.
Área: Engenharia de Estruturas.
Orientador: Prof. Dr. José Samuel Giongo.
1. Concreto de pós reativos. 2. Concreto. 3. Sílica
ativa. 4 Fibras metálicas. I. Título.


A meus pais e esposa, pelo incentivo e cooperação no término de mais uma etapa da minha vida. 

Ao meu amigo e orientador José Samuel Giongo, pela amizade, apoio, incentivo, dedicação, compreensão e conselhos, indispensável para minha formação profissional e humana.

Ao Professor Jefferson Benedito Libardi Liborio, pela grande ajuda na realização deste trabalho, além dos momentos de conversa em que pude aprender muito sobre trabalho e vida.

Ao Professor João Baptista Baldo, pela ajuda, disponibilidade e paciência, que contribuíram na conclusão desta pesquisa.

Aos meus pais Pedro e Lourdes, a quem dedico este trabalho.

A minha esposa Paula e a Camilla, pelo amor, amizade, cumplicidade, carinho, ajuda e incentivo, fundamentais para realização deste trabalho.

A minhas irmãs Karine, Mirna e Aleska pelo carinho e confiança.

A Paulo, Márcia, Bruno e Gabriela, pelo apoio e carinho.

Ao meu amigo Alexandre, pela amizade convívio e cumplicidade.

Aos amigos de pós-graduação, pela companhia, amizade e ajuda durante esta jornada.

Agradecimentos especiais aos técnicos Marcelo e Marcos do Laboratório de Materiais Avançados a Base de Cimento Portland, indispensáveis na realização da experimentação.

Aos funcionários Amauri, Mário, Mauri, Valdir e ao engenheiro Luiz Vareda, técnicos do Laboratório de Estruturas, que auxiliaram na realização dos ensaios.

Aos demais funcionários do Departamento de Engenharia de Estruturas da EESC - USP, pelo apoio.

A Deus, pela consciência que me destes nos momentos difíceis da minha vida, e oportunidades que me foram concedidas. 



\section{CRÉDITOS}

A realização deste trabalho foi possível devido ao apoio de instituições e empresas, ao qual são dignos de créditos:

Universidade de São Paulo

- Escola de Engenharia de São Carlos

- Departamento de Engenharia de Estruturas

CNPq - Conselho Nacional de Desenvolvimento Científico e Tecnológico pela concessão de bolsa de estudo, fundamental para realização desta pesquisa.

Grupo Holdercim S.A.

pela doação do cimento utilizado na pesquisa.

A Mineração Jundu S.A.

pela doação da areia e pó de quartzo.

Belgo Bekaert Arames S.A.

pela doação das fibras metálicas.

Microssílica Tecnologia Ind. e Com. Ltda.

pela doação da sílica ativa.

Master Builders Technologies - MBT

pela doação do aditivo superplastificante.

Camargo Corrêa Industrial S. A.,

pela doação de cimento e sílica ativa utilizada nos estudos preliminares. 

VANDERLEI, R. D. (2004). Análise experimental do concreto de pós reativos: dosagem e propriedades mecânicas. Tese (Doutorado) - Escola de Engenharia de São Carlos, Universidade de São Paulo, São Carlos, 2004.

A tecnologia dos materiais a base de cimento Portland vem se desenvolvendo rapidamente, onde a melhoria das propriedades mecânicas vem sendo alcançada, eliminando os agregados graúdos e estudando a composição granulométrica da mistura, procurando preencher os vazios utilizando materiais finos e ultrafinos, como pó de quartzo e a sílica ativa. Esta pesquisa tem como objetivos: desenvolver concreto de pós reativos com resistência à compressão próxima de 200MPa e módulo de elasticidade acima de $45 \mathrm{GPa}$; propor uma relação constitutiva para o material, considerando o volume de fibras; especificar as deformações máximas na tração e na compressão; e verificar a influência das fibras nas resistências à compressão e à tração na flexão. Para isso, foi utilizado o método de empacotamento das partículas sólidas, com o intuito de definir composições granulométricas, e desenvolveu-se técnicas necessárias para a moldagem, adensamento e cura térmica. A análise experimental compreendeu o estudo das seguintes propriedades: resistência à compressão, módulo de elasticidade, resistência à tração na flexão, deformações e ductilidade. As fibras metálicas melhoraram as propriedades mecânicas e aumentaram a ductilidade do concreto. A temperatura de cura e o tempo de submissão ao tratamento térmico, tornou o material mais resistentes. A deformação específica máxima na compressão foi definida experimentalmente como 4,3\%. O limite elástico para as deformações de tração ficou em $0,28 \%$. Foi proposta uma relação constitutiva para tensões de compressão, que pode ser utilizada para concretos de pós reativos, com resistência à compressão próxima de $200 \mathrm{MPa}$ e taxa de fibras até $4 \%$ em volume. Os resultados obtidos indicam que o concreto de pós reativos desenvolvido apresentou altas resistências à compressão e à tração na flexão, onde a microestrutura do material mostrou-se com baixíssima porosidade e interface pasta agregado praticamente suprimida. A tecnologia desenvolvida nesta pesquisa pode ser considerada um grande avanço na tecnologia de materiais a base de cimento Portland que, com maiores aperfeiçoamentos, espera-se a aplicação desse material em situações que tirem proveito das excelentes propriedades mecânicas e durabilidade.

Palavras-chave: concreto de pós reativos; concreto; sílica ativa; fibras metálicas. 

VANDERLEI, R. D. (2004). Experimental analysis of reactive powder concrete: mix and mechanical properties. Ph.D. Thesis - Escola de Engenharia de São Carlos, Universidade de São Paulo, São Carlos, 2004.

The technology of Portland cement materials has developed quickly, where the improvement of the mechanical properties has been reached, eliminating the coarse aggregates and studying the granular mixture, in order to fill the emptiness with fine and ultra-fine materials, like crushed quartz and silica fume. The present paper aimed: develop reactive powder concrete with compressive strength close to 200MPa and module of elasticity above $45 \mathrm{GPa}$; propose a strength $\mathrm{x}$ strain relationship in compression for the material considering the volume of fibers; specify the maximum strain in the traction and in the compression; and to verify the influence of the fibers in the compression strength and in the bending strength. It went using the method of packing of the solid particles to define the grain size distribution, and necessary techniques were developed for the preparation and thermal cure. The experimental analysis understood the study of the following properties: compression strength, module of elasticity, bending strength, strain and ductility. The metallic fibers improved the mechanical properties and they increased the ductility of the concrete. The cure temperature and the time of submission to the thermal treatment, improved the compression strength. The maximum strain in the compression was defined experimentally as $4,3 \%$. The elastic limit for the traction strain was $0,28 \%$. A strength $x$ strain relationship in compression was proposed, and can be used in reactive powders concrete, with compression strength of around $200 \mathrm{MPa}$ and rate of fibers of up to $4 \%$ of volume. The results indicate that the reactive powders concrete developed presented excellent compression strength and bending strength, and the material presented a microestrutura with low porosity. The technology developed in this research can be considered a great progress in the technology of materials with Portland cement, and the application of that material is expected in situations that use advantage of the excellent mechanical properties and durability.

Keywords: reactive powder concrete; concrete; silica fume; metallic fibers. 



\section{LISTA DE FIGURAS}

Figura 1.1- Passarela em Sherbrooke, Canadá ........................................................... 4

Figura 1.2- Estrutura tridimensional da passarela.......................................................

Figura 2.1 - Relação dos valores ótimos de resistências obtidos para diferentes densidades relativas ...............................................................12

Figura 2.2- Evolução da resistência àcompressão do CPR versus a temperatura e duração do tratamento térmico.

Figura 2.3- Curva tensão $x$ deformação (longitudinal, transversal e volumétrica) para CPR200 sob compressão simples 23

Figura 2.4- Curva tensão $x$ deformação (longitudinal, transversal e volumétrica) para CPR800 sob compressão simples 23

Figura 2.5- Resistência àtração para diferentes quantidades de fibras ........................26

Figura 2.6- Curva força $x$ deslocamento em ensaios àflexão de 4 pontos.....................30

Figura 2.7- Comparação das deformações na tração e na compressão em ensaios àflexão de 4 pontos 31

Figura 2.8- Módulo de ruptura para diferentes quantidades de fibras 32

Figura 2.9- Modelo de ensaio àtração direta.............................................................

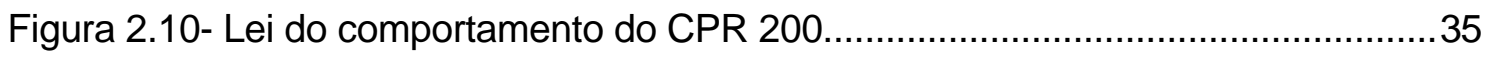

Figura 3.1- Distribuição granulométrica do Pó de quartzo...........................................48

Figura 3.2- Distribuição granulométrica da sílica ativa.................................................4

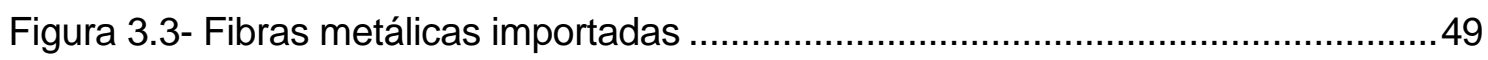

Figura 3.4- Resistência àcompressão em função da relação água/cimento.

Cura àtemperatua ambiente 57

Figura 3.5- Resistência àcompressão em função da relação água/cimento.

Cura térmica a $60^{\circ} \mathrm{C}$ 58

Figura 3.6- Resistência àcompressão em função da relação água/cimento.

Cura térmica a $80^{\circ} \mathrm{C}$ 58

Figura 3.7- Resistência àcompressão em função da relação água/cimento.

Cura térmica a $100^{\circ} \mathrm{C}$ 58

Figura 3.8- Índice de consistência em função da relação água/cimento. 59

Figura 3.9- Resistência àcompressão em função da temperatura de cura térmica. Idade de 3 dias 60

Figura 3.10- Resistência àcompressão em função da temperatura de cura térmica. Idade de 7 dias 60 
Figura 3.11- Resistência àcompressão em função da temperatura de cura térmica. Idade de 14 dias 61

Figura 3.12- Resistência àcompressão em função da temperatura de cura

térmica. Idade de 28 dias.

Figura 3.13- Resistência àcompressão em função da idade. Relação água/cimento de 0,16

Figura 3.14- Resistência àcompressão em função da idade. Relação água/cimento de 0,18 62

Figura 3.15- Resistência àcompressão em função da idade. Relação água/cimento de 0,20. 63

Figura 3.16- Resistência àcompressão em função do tempo pré cura térmica............ 64

Figura 3.17- Resistência àcompressão em função do tempo de cura térmica.............65

Figura 3.18- Resistência àcompressão em função do volume de fibras........................69

Figura 3.19- Resistência àcompressão em função da idade........................................69

Figura 4.1- Fôrmas para os modelos dos ensaios de compressão axial .......................76

Figura 4.2- Prensa "ELE" para ensaios de compressão axial ..................................... 77

Figura 4.3- Vinculação dos modelos .................................................................. 77

Figura 4.4- Prensa "MTS" para ensaios de compressão axial com controle de

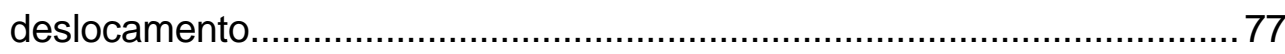

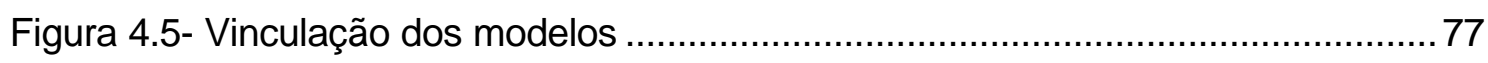

Figura 4.6- Dispositivo de proteção para ensaios de compressão em concretos de alta resistência.................................................................... 78

Figura 4.7- Dispositivo de proteção com modelo rompido ......................................... 78

Figura 4.8- Extensômetro colocado a meia altura do modelo ....................................... 78

Figura 4.9- Extensômetros colocados diametralmente opostos ................................... 78

Figura 4.10- Instrumentação dos modelos ensaiados a compressão axial ...................79

Figura 4.11- Sistema de aquisição de dados .............................................................. 79

Figura 4.12- Modelo prismático para ensaios de flexão ............................................... 80

Figura 4.13- Dimensões da fôrma para os modelos prismáticos .................................. 80

Figura 4.14- Fotografia da fôrma metálica para os modelos prismáticos ..................... 80

Figura 4.15- Prensa "MTS" para ensaios de flexão com controle de deslocamento .... 81

Figura 4.16- Vinculação dos modelos .................................................................. 81

Figura 4.17- Instrumentação dos modelos nos ensaios de flexão a 4 pontos ...............81

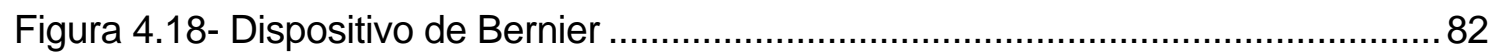

Figura 4.19- Modelo com o dispositivo de Bernier acoplado ....................................... 82

Figura 4.20- Modelo submetido ao ensaio de flexão a 4 pontos ................................... 82

Figura 4.21- Extensômetro fixado na borda superior da seção central.......................... 82 
Figura 4.22- Pré mistura dos materiais secos. 84

Figura 4.23- Mistura mecânica dos materiais secos ................................................. 84

Figura 4.24- Adição da água e super-plastificante na pré mistura ...............................85

Figura 4.25- Consistência desejada para a mistura final ........................................... 85

Figura 4.26- Adição das fibras metálicas na mistura ................................................... 85

Figura 4.27- Mistura com fibras metálicas pronta para moldagem dos modelos..........85

Figura 4.28- Bisnaga utilizada para auxiliar na moldagem dos modelos ......................86

Figura 4.29- Moldagem dos modelos cilíndricos ......................................................... 86

Figura 4.30- Moldagem dos modelos prismáticos .................................................... 86

Figura 4.31- Acabamento da superfície exposta ao ar ............................................. 87

Figura 4.32- Filme de PVC colocado sobre a superfície exposta dos modelos ............87

Figura 4.33- Modelos na câmara úmida nas primeiras 24 horas .................................87

Figura 4.34- Modelos na câmara úmida depois de retirados das fôrmas ......................87

Figura 4.35- Modelos submetidos a cura térmica em equipamento "Banho Maria"......88

Figura 4.36- Modelos com mais de 14 dias retirados da câmara úmida.......................88

Figura 4.37- Planificação do topo e base dos modelos cilíndricos em retífica

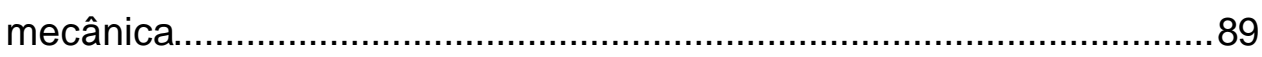

Figura 4.38- Ensaio de compressão axial ............................................................ 92

Figura 4.39- Forma de ruptura dos modelos comprimidos .........................................93

Figura 4.40- Ensaio de flexão a 4 pontos ..................................................................94

Figura 4.41- Forma de ruptura dos modelos da série M1 ..........................................95

Figura 4.42- Forma de ruptura dos modelos da série M2 ...........................................95

Figura 4.43- Forma de ruptura dos modelos da série M3 .............................................96

Figura 4.44- Forma de ruptura dos modelos da série M4 ..........................................96

Figura 4.45- Forma de ruptura dos modelos da série M5 ............................................97

Figura 4.46- Forma de ruptura dos modelos da série M6 ..........................................97

Figura 5.1- Crescimento da resistência àcompressão com o tempo ..........................101

Figura 5.2- Crescimento da resistência àcompressão do CPR nas primeiras idades .................................................................................... 102

Figura 5.3- Crescimento da resistência àcompressão com o volume de fibras ..........103

Figura 5.4- Relação tensão x deformação para os modelos da série M1 .................... 105

Figura 5.5- Relação tensão $x$ deformação para os modelos da série M2 ....................106

Figura 5.6- Relação tensão x deformação para os modelos da série M3 ....................107

Figura 5.7- Relação tensão x deformação para os modelos da série M4 ...................108

Figura 5.8- Relação tensão x deformação para os modelos da série M5 ...................109

Figura 5.9- Relação tensão $x$ deformação para os modelos da série M6 .....................110

Figura 5.10- Relação entre o volume de fibras e o coeficiente " $\alpha=f_{i} / f_{c}$ " $\ldots \ldots \ldots \ldots \ldots \ldots . . . . . . . .112$ 
Figura 5.11- Influência do volume de fibras no módulo de elasticidade do CPR........114

Figura 5.12- Relação entre o volume de fibras e o coeficiente " $\beta=E_{2} / E_{1}$ " ............... 115

Figura 5.13- Influência do volume de fibras na deformação máxima de compressão

Figura 5.14- Relação tensão x deformação proposta para o concreto de pós reativos

Figura 5.15- Comparação entre a relação tensão x deformação proposta, a sugerida por Behloul et al. (1995), e os resultados experimentais:

(a) sem fibras; (b) 0,5\% de fibras; (c) $1 \%$ de fibras; (d) $2 \%$ de fibras; (e) $3 \%$ de fibras; (f) $4 \%$ de fibras. 121

Figura 5.16- Influência do volume de fibras na resistência àtração na flexão do CPR 123

Figura 5.17- Relação força x flecha para os modelos da série M2 125

Figura 5.18- Relação força $x$ flecha para os modelos da série M3 126

Figura 5.19- Relação força x flecha para os modelos da série M4 127

Figura 5.20- Relação força x flecha para os modelos da série M5 127

Figura 5.21- Relação força x flecha para os modelos da série M6 128

Figura 5.22- Comparação das deformações na tração e na compressão em ensaios àflexão em 4 pontos. Modelo M6-3

Figura 5.23- Relação entre a deformação máxima na tração e o volume de fibras 130

Figura 6.1- Relação entre o volume acumulado e o diâmetro dos poros obtido por PIM, para amostra de concreto de pós reativos. 136

Figura 6.2- Imagem da microestrutura do concreto de pós reativos, ampliada 500 vezes

Figura 6.3- Imagem geral da amostra ampliada 70 vezes. 142

Figura 6.4- Micrografia de regiões da microestrutura do CPR, ampliação de 4000 vezes.

Figura 6.5- Interface entre o grão de areia e a pasta, ampliação de 928 vezes 143

Figura 6.6- Imagens de 4 regiões diferentes da amostra: a) magnificação de 900x; b) magnificação de 900x; c) magnificação de 1000x; d) magnificação de 500x. 144

Figura 6.7- Imagem da microestrutura do CPR com fibras metálicas, ampliada 500 vezes

Figura 6.8- Imagem geral da amostra ampliada 70 vezes. 145

Figura 6.9- Micrografia de regiões da microestrutura do CPR, ampliação de 4000 vezes 
Figura 6.10- Imagens da interface entre a fibra na direção longitudinal e a matriz: a) magnificação de 929x; b) magnificação de 1000x; c) magnificação de 2000x. 146

Figura 6.11- Imagens da interface entre a fibra na direção longitudinal e a matriz: a) magnificação de 1000x; b) magnificação de 2000x.

Figura 6.12- Imagem da amostra fraturada ampliada 200 vezes

Figura 6.13- Textura e morfologia da superfície fraturada: a) magnificação 1000x; b) magnificação de 5000x.

Figura 6.14- Textura e morfologia da superfície fraturada: a) magnificação 500x; b) magnificação de 45000x. 148

Figura 6.15- Detalhe da textura e morfologia da superfície fraturada: a) magnificação 15000x; b) magnificação de 25000x. 149

Figura 6.16- Detalhe da textura e morfologia da superfície fraturada: a) magnificação 10000x; b) magnificação de 30000x. 149

Figura 6.17- Detalhe da textura e morfologia da superfície fraturada: a) magnificação 2000x; b) magnificação de 10000x. 150

Figura 6.18- Detalhe do C-S-H formado na superfície fraturada, magnificação de 45000x 150

Figura 6.19- Detalhe do C-S-H formado na superfície fraturada, magnificação de 10000x 150

Figura 6.20- Imagem da amostra fraturada contendo fibras, ampliada 100 vezes..... 151

Figura 6.21- Imagem da amostra fraturada contendo fibras, ampliada 100 vezes.....151

Figura 6.22- Imagem da amostra fraturada contendo fibras, ampliada 100 vezes.....152 

Tabela 1.1- Propriedades do CPR e CAD .................................................................. 5

Tabela 2.1- Composição típica do CPR (em peso) …............................................. 12

Tabela 2.2- Energia de fratura de diferentes materiais ............................................... 17

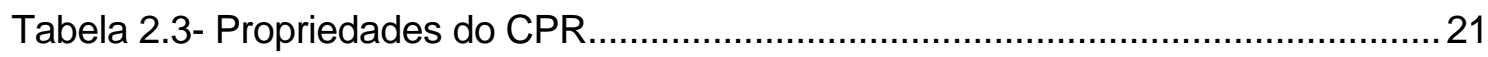

Tabela 2.4- Características mecânicas na compressão simples do CPR....................... 24

Tabela 2.5- Propriedades mecânicas dos ensaios de BONNEAU et al ........................24

Tabela 2.6- Propriedades mecânicas do CPR para diferentes quantidades de

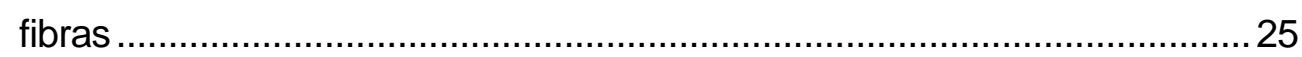

Tabela 3.1- Análise granulométrica da AREIA I...................................................... 44

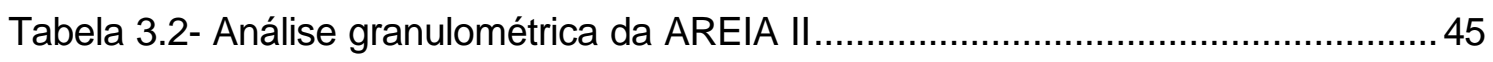

Tabela 3.3- Análise química da AREIA II................................................................ 45

Tabela 3.4- Propriedades químicas dos cimentos ....................................................... 45

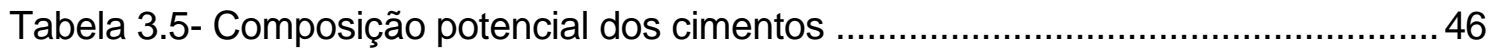

Tabela 3.6- Características e propriedades dos cimentos ............................................46

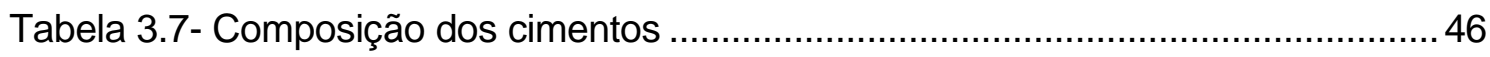

Tabela 3.8- Análise granulométrica do cimento CP V ARI- RS .................................. 46

Tabela 3.9- Análise granulométrica do pó de quartzo.................................................. 47

Tabela 3.10- Análise química do pó de quartzo....................................................... 47

Tabela 3.11- Análise química da sílica ativa .......................................................... 48

Tabela 3.12- Dosagem publicado em AITCIN \& RICHARD (1996) .............................. 49

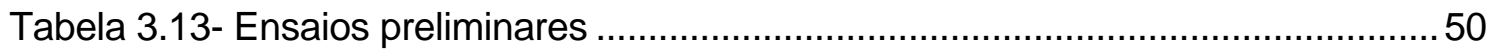

Tabela 3.14- Resistências médias àcompressão axial dos ensaios

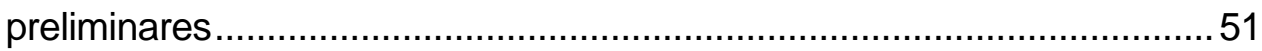

Tabela 3.15- Classes dos materiais utilizados e valores do parâmetro "q" ................... 52

Tabela 3.16- Composição das dosagens 1 e 2 (em massa) .......................................... 53

Tabela 3.17- Resistências médias àcompressão axial das dosagens 1 e 2 .................54

Tabela 3.18- Dosagem para concreto de pós reativos .................................................54

Tabela 3.19- Comparação entre dosagens para concreto de pós reativos (em

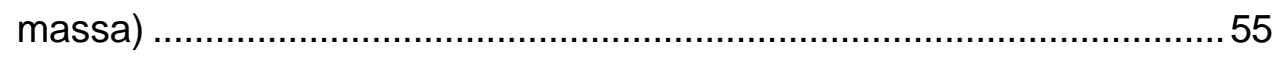

Tabela 3.20- Dosagem para os ensaios acessórios (relação em massa) .....................56

Tabela 3.21- Programa experimental para os ensaios acessórios .................................56

Tabela 3.22- Programa de ensaio para análise do tipo de cimento e temperatura da água 66 
Tabela 3.23- Dosagem desenvolvida para o estudo do concreto de pós

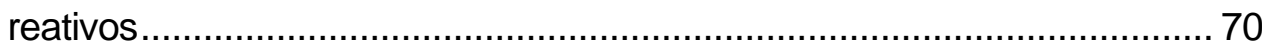

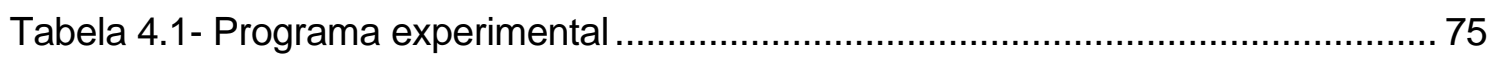

Tabela 4.2- Dosagem utilizada no estudo do concreto de pós reativos ......................... 83

Tabela 4.3- Programa experimental para cada série..................................................... 90

Tabela 5.1- Resistência àcompressão em CPR ...................................................... 100

Tabela 5.2- Resistência àcompressão nas primeiras horas, com e sem cura

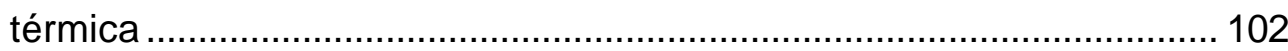

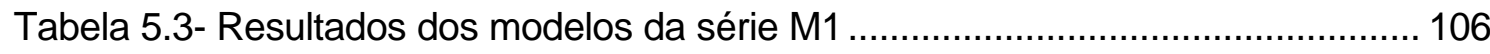

Tabela 5.4- Resultados dos modelos da série M2 ................................................... 107

Tabela 5.5- Resultados dos modelos da série M3 …............................................... 108

Tabela 5.6- Resultados dos modelos da série M4 .................................................. 109

Tabela 5.7- Resultados dos modelos da série M5 .................................................... 110

Tabela 5.8- Resultados dos modelos da série M6 ................................................... 111

Tabela 5.9- Resumo dos resultados médios de cada série ........................................ 111

Tabela 5.10- Módulo de elasticidade para cada modelo ….......................................... 114

Tabela 5.11- Comparação dos módulo de elasticidade alcançados com os

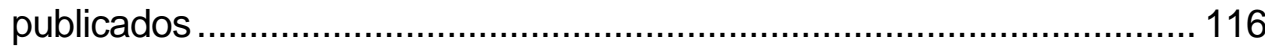

Tabela 5.12- Deformações específicas máximas e no ponto de transição.................. 117

Tabela 5.13- Resultados dos modelos da série M1 ................................................. 124

Tabela 5.14- Resultados dos modelos da série M2 …............................................... 124

Tabela 5.15- Resultados dos modelos da série M3 ….............................................. 125

Tabela 5.16- Resultados dos modelos da série M4 ….............................................. 126

Tabela 5.17- Resultados dos modelos da série M5 ................................................. 128

Tabela 5.18- Resultados dos modelos da série M6 …............................................... 128

Tabela 5.19- Deformações para o limite elástico na tração do concreto de pós

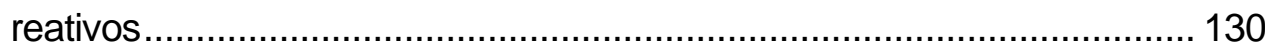

Tabela 6.1 - Características das amostras para o MEV ............................................... 139

Tabela 6.2- Mapeamento dos tons de cinza da estrutura interna do CPR ................. 142

Tabela 6.3- EDS de áreas da estrutura interna do CPR, com magnitude de 4000vezes. 143

Tabela 6.4- Mapeamento dos tons de cinza da estrutura interna do CPR com fibras.

Tabela 6.5- EDS de áreas da estrutura interna do CPR, com magnitude de 4000vezes.

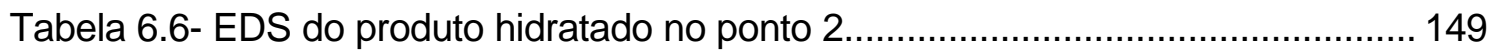

Tabela 6.7- EDS do produto hidratado nos pontos 1 e 2 


\begin{tabular}{|c|c|}
\hline ABNT & - Associação Brasileira de Normas Técnicas \\
\hline ARI & - Alta Resistência Inicial \\
\hline ASTM & - American Society for Testing and Materials \\
\hline BSE & - Elétrons Retroespalhados \\
\hline CAD & - Concreto de Alto Desempenho \\
\hline CAR & - Concreto de Alta Resistência \\
\hline CAT & - Contêiner de Alta Integridade \\
\hline CCDM & - Caracterização e Desenvolvimento de Materiais \\
\hline $\mathrm{CH}$ & - Hidróxido de Cálcio \\
\hline CPR & - Concreto de Pós Reativos \\
\hline CPR 200 & - Concreto de Pós Reativos com resistência próxima de 200MPa \\
\hline CPR 800 & - Concreto de Pós Reativos com resistência próxima de 800MPa \\
\hline C-S-H & - Silicato de Cálcio Hidratado \\
\hline DRX & - Difratometria de Raio - X \\
\hline EESC & - Escola de Engenharia de São Carlos \\
\hline EDS & - Espectrografia por Dispersão de Energia \\
\hline $\mathrm{GPa}$ & - Giga Pascal \\
\hline LCC & - Laboratório de Construção Civil \\
\hline LMABC & - Laboratório de Materiais Avançados a Base de Cimento Portland \\
\hline MEV & - Microscopia Eletrônica de Varredura \\
\hline MF & - Módulo de Finura \\
\hline $\mathrm{MPa}$ & - Mega Pascal \\
\hline NBR & - Norma Brasileira Registrada \\
\hline PIM & - Porosimetria por Intrusão de Mercúrio \\
\hline RS & - Resistência àSufatos \\
\hline SE & - Elétrons Secundários \\
\hline USP & - Universidade de São Paulo \\
\hline Z & - Número Atômico \\
\hline
\end{tabular}





\begin{tabular}{|c|c|}
\hline $\mathrm{a} / \mathrm{c}$ & - relação água / cimento \\
\hline b & - Largura da seção transversal do prisma \\
\hline CPFT & - Percentual Acumulado de Finos Menores que "d" em volume \\
\hline$d$ & - Diâmetro do poro \\
\hline$d_{m}$ & - Menor tamanho de partícula da distribuição \\
\hline $\mathrm{D}$ & - Maior tamanho de partícula da distribuição \\
\hline$E_{c}$ & - Modulo de deformação longitudinal do concreto \\
\hline $\mathrm{E}_{1}$ & - Coeficiente angular da reta "a" \\
\hline$E_{2}$ & - Coeficiente angular da reta "b" \\
\hline $\mathrm{F}$ & - Força máxima \\
\hline $\mathrm{f}_{\mathrm{b}}$ & - Tensão de ancoragem fibra - matriz \\
\hline$f_{c}$ & - Resistência de ruptura \\
\hline$f_{f}$ & - Resistência àflexão do concreto \\
\hline$f_{f 1}$ & - Resistência àflexão do concreto sem fibras \\
\hline$f_{i}$ & - Tensão no ponto de transição \\
\hline$f_{s}$ & - Resistência de ruptura do aço da fibra \\
\hline$f_{t}$ & - Resistência àtração do concreto \\
\hline g & - Fator de amortecimento \\
\hline $\mathrm{h}$ & - Altura da seção transversal do prisma \\
\hline $\mathrm{m}$ & - Módulo de Weibull \\
\hline $\mathrm{p}$ & - Pressão aplicada \\
\hline q & - Coeficiente de distribuição \\
\hline SA & - Sílica ativa \\
\hline $\mathrm{T}$ & - Temperatura \\
\hline$V_{f}$ & - Fração de volume de fibras \\
\hline$\alpha$ & - Coeficiente de redução da tensão máxima \\
\hline$\beta$ & - Coeficiente de redução do módulo de elasticidade \\
\hline$\varepsilon_{\mathrm{i}}$ & - Deformação específica no ponto de transição \\
\hline$\varepsilon_{\text {inf }}$ & - Deformação específica na fibra inferior \\
\hline$\varepsilon_{1}$ & - Deformação específica longitudinal \\
\hline$\varepsilon_{\text {máx }}$ & - Deformação específica máxima \\
\hline$\varepsilon_{\text {sup }}$ & - Deformação específica na fibra superior \\
\hline$\varepsilon_{\mathrm{t}}$ & - Deformação específica transversal \\
\hline
\end{tabular}




$\begin{array}{ll}\varepsilon_{v} & \text { - Deformação específica volumétrica } \\ \phi_{\text {máx }} & \text { - Diâmetro máxima característico do agregado } \\ \gamma & \text { - Energia superficial do líquido } \\ \Gamma & - \text { Função gama de Euler } \\ \sigma_{F 3} & \text { - Máxima tensão do modelo } \\ \sigma_{o} & \text { - Parâmetro de Weibull } \\ \sigma_{u} & \text { - Tensão de escoamento } \\ v & - \text { Coeficiente de Poisson } \\ \theta & \text { - Ângulo de contato entre o mercúrio e a parede do poro } \\ \tau & \text { - Tensão de ligação fibra - matriz } \\ \omega & - \text { Abertura de fissura }\end{array}$


LISTA DE FIGURAS v

LISTA DE TABELAS xi

LISTA DE ABREVIATURAS E SIGLAS xiii

LISTA DE SÍMBOLOS Xv

CAPÍTULO 1 - INTRODUÇÃO 1

1.1- Justificativa da Pesquisa 2

1.2- Objetivos 3

1.3- Limitações da Pesquisa

1.4- Aplicações Feitas com Concreto de Pós Reativos

1.4.1- Passarela em Sherbrooke

1.4.2- Tubos pré-moldados de CPR

1.4.3- Armazenamento de rejeitos radioativos

CAPÍTULO 2 - FUNDAMENTOS DO CONCRETO DE PÓS REATIVOS _-_________-__-_

2.1- Princípios Básicos do Concreto de Pós Reativos 9

2.1.1- Aumento da homogeneidade

2.1.1.1- Efeito do tamanho do agregado 9

2.1.1.2- Efeito do aumento das propriedades mecânicas da pasta 10

2.1.1.3- Efeito da quantidade de areia 11

2.1.2- Aumento da densidade

2.1.3- Melhor microestrutura por cura térmica

2.1.3.1- Cura térmica em concreto de pós reativos 11

Cura térmica em concreto de pós reativos _-_-_-_-_-_-_-_-_-_-_-_-_-_-_-_-_-_ 13

2.1.4- Aumento de ductilidade pela adição de fibras

2.2- Materiais Componentes do Concreto de Pós Reativos ___ 18

2.2.1- Areia 18

2.2.2- Cimento 18

2.2.3- Superplastificante 19

2.2.4- Pó de quartzo 19

2.2.5- Adições minerais 19

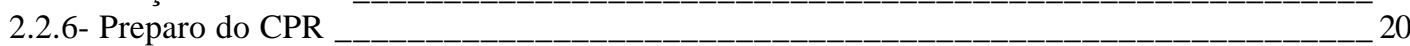

2.3- Propriedades do Concreto de Pós Reativos __ 20

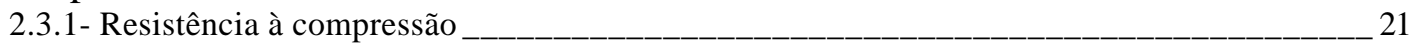

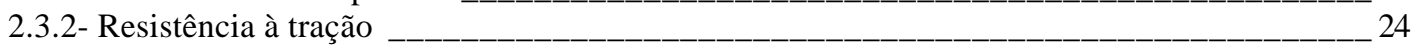

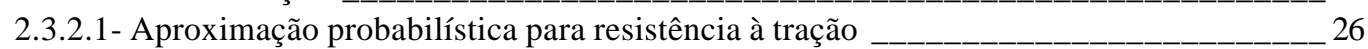

2.3.2.2- Curva tensão na tração $x$ abertura de fissura ______________________________________ 28

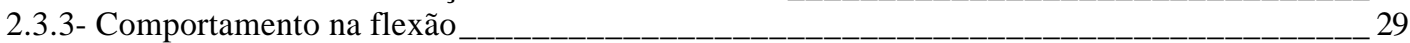

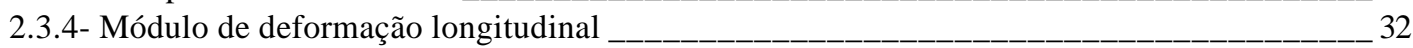

2.3.5- Coeficiente de Poisson

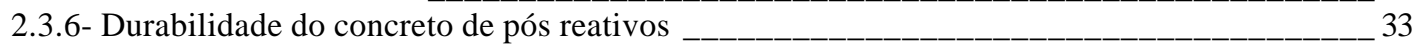

2.3.7- Lei do comportamento do concreto de pós reativos_____________________________________ 34

2.4- Síntese do Estudo Bibliográfico___ 37 
3.1- Método do Empacotamento __ 42

3.1.1- Modelo teórico de empacotamento de partículas ___ 43

3.2- Materiais Utilizados e suas Propriedades ___ 44

3.2.1- Areia _____-_-_-_ 44

3.2.2- Cimento

3.2.3- Aditivo superplastificante _- 47

3.2.4- Pó de quartzo

3.2.5- Sílica ativa ______-__-__-_ 48

3.2.6- Fibras metálicas _-_-_- 49

3.3- Determinação da Composição dos Materiais ___ 49

3.3.1- Dosagens preliminares __________________ 49

3.3.2- Dosagem pelo método do empacotamento [Andreassen \& Andersen]

3.4- Ensaios Acessórios para Determinação da Dosagem___ 55

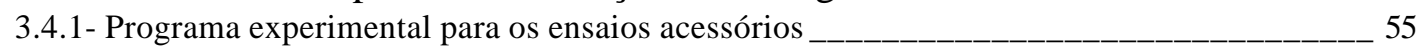

3.4.2- Influência da relação água/cimento _____-__-_-_-_-_-_-_-_-_-_-_ 56

3.4.3- Influência da temperatura de cura

3.4.4- Influência da idade _______-_ 61

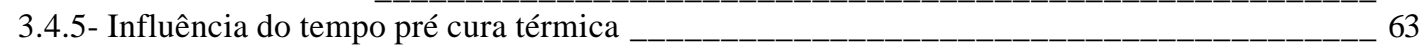

3.4.6- Influência do tempo de cura térmica

3.4.7- Influência do tipo de cimento e temperatura da água de amassamento _______-___-____-_ 66

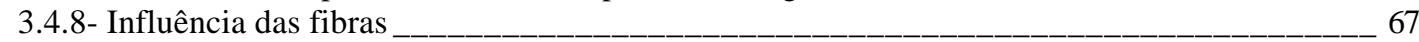

3.4.9- Procedimentos de mistura _-__-_ 69

3.5- Dosagem Proposta para o Concreto de Pós Reativos __ 70

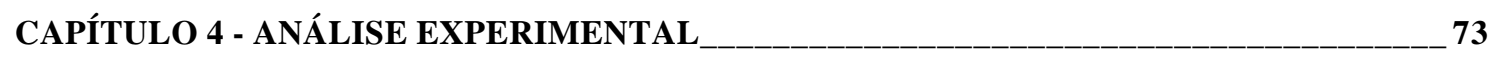

4.1- Metodologia Experimental___ 74

4.2- Programa Experimental__ 74

4.3- Características dos Ensaios__ 75

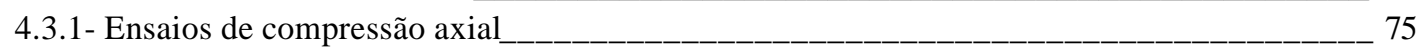

4.3.1.1- Sistema de aplicação de força e vinculação _-_ 76

4.3.1.2- Instrumentação _-__- 78

4.3.2- Ensaios de flexão a 4 pontos _-_

4.3.2.1 - Sistema de aplicação de força e vinculação -

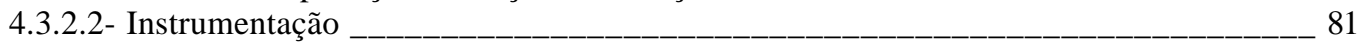

4.4- Materiais Utilizados e Dosagem Adotada___ 83

4.5- Moldagem, Adensamento e Cura dos Modelos ___ 83

4.5.1- Mistura dos materiais __-__-_-_-_-_-_-_-_-_-_-_-_-_-_-_-_-_-_-_-_-_-_-_ 84

4.5.2- Moldagem dos modelos _______ 85

4.5.3- Cura dos modelos _

4.5.4- Preparo das superfícies dos corpos-de-prova

4.6- Descrição dos Ensaios Realizados ___ _ 89

4.6.1- Ensaios de compressão axial com controle de força ___ 90

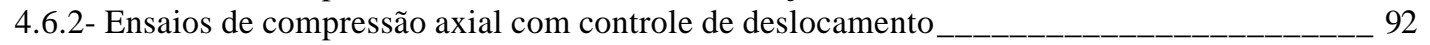

4.6.3- Ensaios de flexão a 4 pontos com controle de deslocamento _________________________ 94

4.6.3.1- Ensaios da série M1

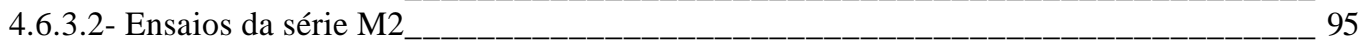

4.6.3.3- Ensaios da série M3

4.6.3.4- Ensaios da série M4

4.6.3.5- Ensaios da série M5 96

4.6.3.6- Ensaios da série M6 _-__-_-_-_-_-_-_ 97

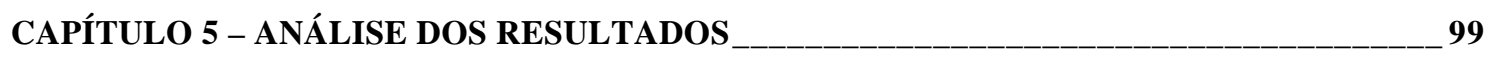

5.1- Resistência à Compressão___ 100

5.1.1- Comportamento da resistência à compressão ao longo do tempo _________________-___-_ 100

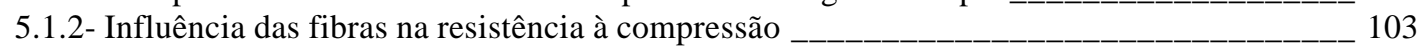

5.2-Análise da Relação Tensão x Deformação __ 104 
5.3- Módulo de Deformação Longitudinal

112

5.4- Deformação Específica na Compressão 116

5.5- Proposta para Relação Constitutiva do Concreto de Pós Reativos 118

5.5.1- Verificação do modelo proposto para a relação constitutiva

5.6- Análise do Comportamento à Flexão

5.6.1- Influência das fibras na resistência à tração na flexão

5.6.2- Análise do comportamento força $x$ flecha

5.6.3- Análise das deformações nos ensaios de flexão em 4 pontos

CAPÍTULO 6 - ANÁLISE MICROESTRUTURAL DO CONCRETO DE PÓS REATIVOS 133

6.1- Microestrutura do Concreto 134

6.2- Análise da Microestrutura do Concreto de Pós reativos 134

6.3- Porosimetria por Intrusão de Mercúrio 134

6.3.1- Estudo do sistema de poros para o concreto de pós reativos 135

6.3.2- Análise dos resultados do PIM 136

6.4- Microscopia Eletrônica de Varredura 137

6.4.1 - Introdução

6.4.2- Estudo da microestrutura do concreto de pós reativos 139

CAPÍTULO 7- CONCLUSÃO 153

Sugestões para Continuidade da Pesquisa 159

CAPÍTULO 8- BIBLIOGRAFIA 161

8.1- Referências Bibliográficas 162

8.2- Bibliografia Complementar 166 



\section{Capítulo}

\section{INTRODUÇÃO}

Concretos de pós reativos - CPR, são concretos formados de partículas com diâmetro máximo menor que $2 \mathrm{~mm}$, que estão sendo analisados e aplicados em elementos estruturais. O material oferece grandes resistências à compressão e, também, àtração e àflexão, quando adicionada fibras metálicas na sua composição. É considerado um material novo, em que suas propriedades mecânicas e o seu comportamento estrutural estão sendo estudados. Atualmente a maior dificuldade é a obtenção, que necessita de grande precisão na dosagem e análise da composição granulométrica dos pós.

Este trabalho estudou o concreto de pós reativos, e buscou na bibliografia internacional informações diversas que viesse a esclarecer o comportamento estrutural, baseado em princípios que melhorem a microestrutura, a composição e, conseqüentemente, as propriedades mecânicas.

Foi desenvolvida metodologia teórica e experimental capaz de criar o concreto de pós reativos com materiais obtidos na região de São Carlos - SP. Este concreto apresentou propriedades mecânicas próximas das expostas na literatura estudada. 


\section{1- Justificativa da Pesquisa}

As estruturas de concreto armado no Brasil são bastante difundidas e fazem parte do padrão da construção brasileira. O estudo de novas técnicas e métodos de análises dos materiais à base de cimento, se torna de grande relevância para inovações relacionadas a eficiência e desempenho.

O concreto de pós reativos aparece em pesquisas internacionais, mostrando-se como alternativa para diversos tipos de aplicação em várias áreas: obras hidráulicas e de saneamento; construções para armazenamento de rejeitos radioativos; peças para indústrias mecânicas como parafusos, engrenagens, projéteis de armamento e outros; ou seja, aplicações que aproveitam a excelente resistência à compressão, à tração, impermeabilidade e durabilidade.

A principal pesquisa realizada a respeito da relação constitutiva do CPR foi a de BEHLOUL (1995), que propôs uma lei do comportamento do CPR baseada também em ensaios realizados por DUGAT et al. (1995) para estudar as propriedades mecânicas. Em seguida, essa lei foi utilizada e comprovada por ADELINE \& BHELOUL (1996) em ensaios de vigas protendidas com $15 \mathrm{~m}$ de comprimento.

Durante a pesquisa bibliográfica deste trabalho, foi detectado que a relação constitutiva proposta por BEHLOUL (1995) era a única publicada, e que foi testada em elementos estruturais em escala real. Essa relação tensão $x$ deformação do concreto é bem simples e de fácil utilização, mas, pela sua simplicidade foram levantados alguns pontos curiosos, que não foram esclarecidos em nenhum artigo publicado sobre 0 assunto. Estes pontos são:

- quais os limites máximo e mínimo para a resistência àcompressão, para os quais é válida a relação proposta;

- qual a influência da quantidade de fibras na relação constitutiva;

- quais as deformações máximas na tração e na compressão, que podem ser consideradas para utilização deste material em elementos estruturais.

Os pontos citados motivaram os pesquisadores a elaborar este trabalho, a fim de contribuir na análise deste material e dar os primeiros passos sobre a pesquisa deste concreto no Brasil. 


\section{2- Objetivo}

A pesquisa pretende desenvolver concreto de pós reativos, e estudar suas propriedades mecânicas para atingir os seguintes objetivos:

- desenvolver uma dosagem que alcance resistência àcompressão próxima de $200 \mathrm{MPa}$;

- propor uma relação constitutiva para o material;

- relacionar esta lei constitutiva, com a taxa de fibras empregada;

- especificar as deformações máximas na tração e na compressão;

- verificar a influência das fibras nas resistências àcompressão e àtração na flexão.

\section{3- Limitação da Pesquisa}

Esta pesquisa terá as seguintes limitações:

- resistência àcompressão próxima dos 200MPa;

- taxas de fibra metálica de $0 \%$ a $4 \%$;

- cura térmica com temperatura de $80^{\circ} \mathrm{C}$.

\section{4- Aplicações Feitas com Concreto de Pós Reativos}

A utilização do CPR é bastante interessante na construção de estruturas espaciais leves, tabuleiro de pontes, vigas, colunas, passarelas, pré-fabricados de túneis ou placas de revestimentos de fachadas, além de cilindros para laminação, projéteis, engrenagens, etc.

Exemplos dessa tecnologia são: a passarela de Sherbrooke, no Canadá, com $56 \mathrm{~m}$ de vão, constituída em elementos pré-fabricados; e a revitalização de ponte rodoviária, também no Canadá, em que o tabuleiro e pavimentação originais foram substituídos por laje com apenas $5 \mathrm{~cm}$ de espessura, reduzindo a ação permanente em quase $5 \mathrm{kN} / \mathrm{m}^{2}$.

\subsection{1- Passarela em Sherbrooke}

$\mathrm{Na}$ cidade de Sherbrooke, no Canadá, foi construída a primeira estrutura utilizando CPR, uma ponte para pedestres e ciclistas sobre o rio Magog, conforme figura 1.1 . 


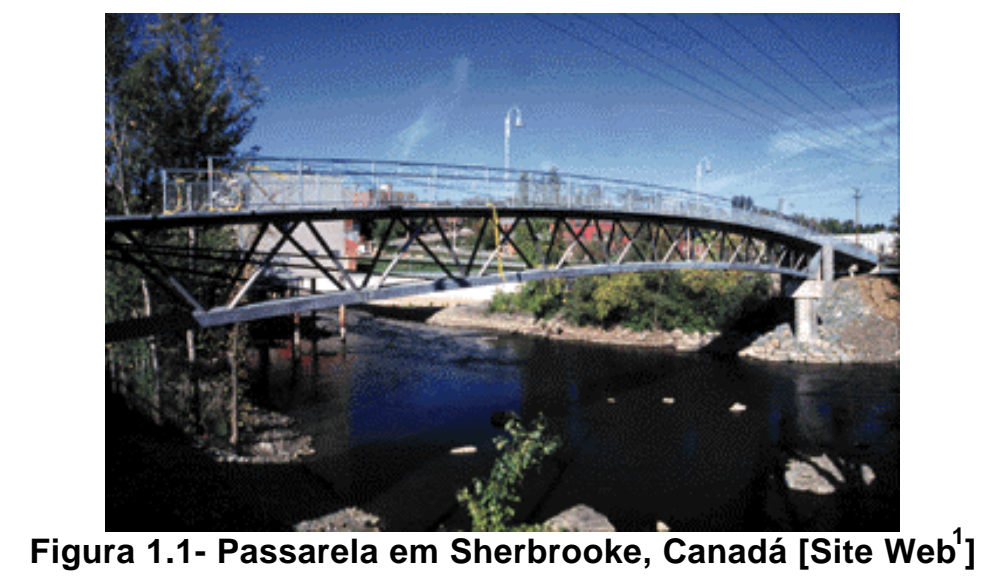

Tirando proveito das excelentes propriedades mecânicas do CPR, projetou-se uma estrutura muito leve utilizando estrutura em treliça tridimensional, como mostra a figura 1.2. A estrutura triangular foi feita de elementos pré-fabricados, onde projetaram-se seis módulos de 6,8m de comprimento, 4,2m de largura e 3,5m de altura. Esses elementos foram transportados para o local da passarela, colocados sobre pilares provisórios, conectados e pós-tracionados depois da instalação da estrutura.
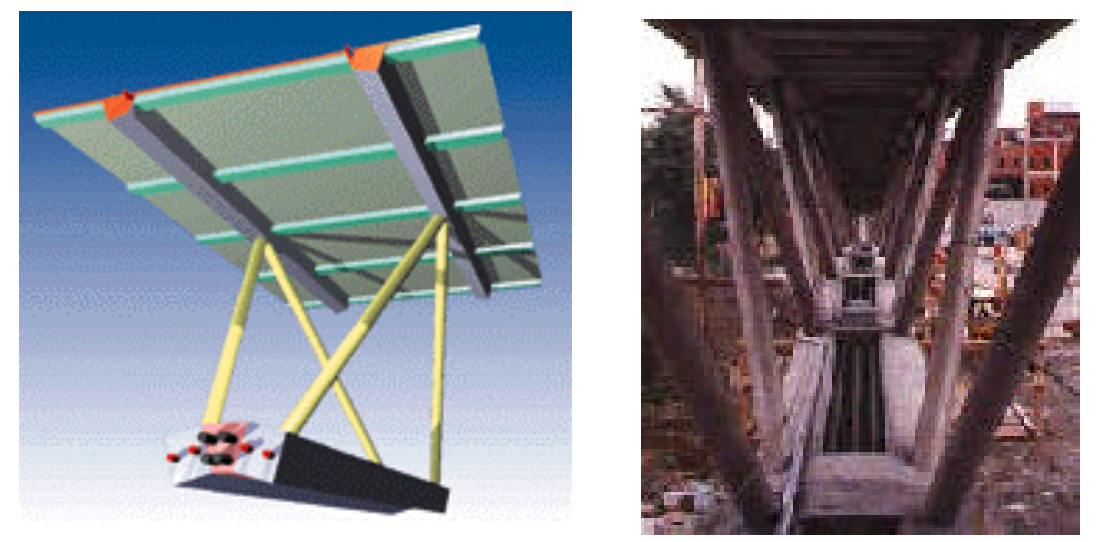

Figura 1.2- Estrutura tridimensional da passarela. [Site $\mathrm{Web}^{4}$ ]

As propriedades mecânicas do CPR usado para o projeto foram:

- resistência àcompressão: 200MPa

- resistência àtração: $7 \mathrm{MPa}$

- resistência àflexão: $40 \mathrm{MPa}$

- módulo de elasticidade: 50GPa

O projeto da estrutura permitiu o uso do CPR sem nenhuma armadura passiva. A viga superior e a inferior da estrutura foram feitas com CPR com fibras e a resistência à compressão em torno de 200MPa. As diagonais da treliça foram feitas

\footnotetext{
${ }^{1}$ http://www.vsl-intl.com/fp/fpn47.htm (01 - jul. - 1999)
} 
com tubos de aço inoxidável, cuja espessura das paredes era de $3 \mathrm{~mm}$, preenchidos com CPR com adição de fibras, submetido a pressão durante a moldagem, e a resistência à compressão foi de $350 \mathrm{MPa}$. Também foi feita cura térmica a $90^{\circ} \mathrm{C}$ em todo o módulo.

\subsection{2- Tubos pré-moldados de CPR}

Em face do alto custo do CPR, é apropriado identificar aplicações que necessariamente utilizem a melhora das propriedades mecânicas do CPR. A produção de tubos para transporte de água, esgoto e outros líquidos, é uma das oportunidades de utilizar o CPR.

Uma comparação das propriedades do CPR com respeito ao concreto de alto desempenho (CAD) é mostrada na tabela 1.1.

Tabela 1.1- Propriedades do CPR e CAD.

\begin{tabular}{l|c|c}
\hline \multicolumn{1}{c|}{ Características } & CAD & CPR \\
\hline Resistência à compressão & $60 \mathrm{MPa}-100 \mathrm{MPa}$ & $180 \mathrm{MPa}-200 \mathrm{MPa}$ \\
\hline Resistência à flexão & $6 \mathrm{MPa}-10 \mathrm{MPa}$ & $30 \mathrm{MPa}-50 \mathrm{MPa}$ \\
\hline Energia de fratura & $140 \mathrm{~J} / \mathrm{m}^{2}$ & $1000 \mathrm{~J} / \mathrm{m}^{2}-40.000 \mathrm{~J} / \mathrm{m}^{2}$ \\
\hline Absorção de água & $0,35 \mathrm{~kg} / \mathrm{m}^{2}$ & $0,05 \mathrm{~kg} / \mathrm{m}^{2}$ \\
\hline Permeabilidade de ar & $120 \times 10^{-18} / \mathrm{m}^{2}$ & $2,5 \times 10^{-18} / \mathrm{m}^{2}$ \\
\hline Taxa de corrosão & $0,25 \mu \mathrm{m} / \mathrm{ano}$ & $<0,01 \mu \mathrm{m} / \mathrm{ano}$ \\
\hline Fonte: DOWD \& O'NEIL (1996)
\end{tabular}

DOWD \& O'NEIL (1996) estudaram bueiros e tubos de esgoto de CPR e uma ampla lista de vantagens foi observada, o qual inclui:

- produção de peças leves para reduzir o custo com transporte;

- agilidade na produção de tubos pela eliminação de etapas do processo;

- permite a eficiência de projeto estrutural usando a teoria de tubo flexível;

- menor permeabilidade àágua;

- redução de danos durante a manipulação e colocação;

- redução do tempo de instalação;

- melhor resistência ao ataque de sulfatos e outros produtos químicos;

Pela utilização da alta resistência à flexão e ductilidade do CPR, a tradicional tela de aço usada para armar a parede dos tubos pode ser eliminada. Além disso, a espessura da parede do tubo pode ser significativamente reduzida, podendo variar de acordo com o diâmetro do tubo, sua finalidade, e ambiente de utilização. A redução da espessura da parede do tubo economiza no custo do material e resulta em tubos leves, de fácil manipulação e transporte mais barato. 


\subsection{3- Armazenamento de rejeitos radioativos}

Segundo TORRENTI et al. (1996), atualmente o armazenamento de rejeitos radioativos é feito em contêiner de aço ou com múltiplas paredes àbase de cimento, nos quais os rejeitos são imobilizados pela injeção de concreto ou graute.

TORRENTI et al. (1996) iniciou estudo desenvolvendo Contêiner de Alta Integridade (CAI), onde este assume sozinho o papel de barreira de confinamento. $O$ CAl requer o uso de material que exibe excelentes propriedades mecânicas, de confinamento e durabilidade. Estudos prévios utilizando o CPR na preparação do CAI, mostraram que é um bom material para este propósito, pois ele apresenta baixa porosidade, excelentes propriedades mecânicas e agilidade no processo de fabricação do contêiner.

Neste estudo não se teve acesso aos resultados finais, mas os primeiros resultados sobre a porosidade, permeabilidade de gás e difusão de íons radioativos foram satisfatórios, segundo o autor.

\section{5- Considerações Finais}

O concreto de pós reativos surgiu, na literatura científica internacional, como uma inovação na área de materiais de construção, podendo ser aplicado em vários seguimentos da engenharia civil. Com isso, esta pesquisa procurou estudar este material, com a finalidade de conhecer o processo de produção, seu comportamento, e propriedades mecânicas.

Durante o estudo bibliográfico, percebeu-se que este material foi inicialmente desenvolvido na França, por um grupo de pesquisadores das: "Ecole Centrale de Nantes" e "Ecole Nationale Supérieure de Cachan". Entretanto, praticamente todos os pesquisadores envolvidos no estudo do concreto de pós reativos, estavam relacionados ao grupo industrial "Bouygues", onde assumem cargos de diretores científicos e de pesquisa. Por causa do estreito relacionamento dos pesquisadores franceses com professores da "Universidade de Sherbrooke", no Canadá, houve um convênio que propiciou um intercâmbio de pesquisas, possibilitando o estudo do concreto de pós reativos no Canadá, onde ocorreu a sua principal aplicação na construção de uma passarela na cidade de Sherbrooke, Canadá.

As pesquisas publicadas por este seleto grupo de pesquisadores, abordavam variados estudos sobre as propriedades mecânicas, durabilidade, microestrutura, etc. No entanto, as informação sobre procedimentos de dosagem e ensaios eram resumidas, o que dificultava a reprodução dos resultados. 


\section{Capítulo}

FUNDAMENTOS DO CONCRETO DE PÓS REATIVOS

\section{Considerações Iniciais}

Para conhecer o concreto de pós reativos, é necessário estudo teórico sobre seus fundamentos. Assim, este capítulo descreve os princípios básicos para obtenção do CPR e as propriedades dos materiais que compõem este concreto. 
Pesquisas têm sido feitas ao longo dos anos visando obter alto desempenho mecânico com materiais de matrizes cimentíceas. De acordo com RICHARD \& CHEYREZY (1995), durante os anos 30, Eugène Freyssinet demostrou a vantagem de aplicar pressão ao concreto fresco durante a moldagem, para melhorar sua resistência. Nos anos 60 , valores de resistência de $650 \mathrm{MPa}$ foram obtidos em compressão simples, com cura térmica e elevada pressão.

Mais recentemente, duas linhas de pesquisa têm sido seguidas. A primeira concerne em concreto com matriz de granulometria compacta (DSP: Densified System containing ultra-fine particles), com alto conteúdo de superplastificante e sílica ativa, incorporando agregados muito resistentes (bauxita calcinada ou granito) e com alta redução de água na mistura. A outra linha de pesquisa é a pasta de polímero MDF (Macro-Defect Free). Esta pasta tem resistência àtração muito alta (150MPa ou mais), em particular quando misturadas com cimento aluminoso.

Por meios de pesquisas realizadas desde 1990 na França e no Canadá, o concreto de pós reativos - CPR foi desenvolvido como alternativa ao concreto de alto desempenho - CAD e, até mesmo o aço, tornando-se um material de alta tecnologia, projetado especificamente para atender às exigências de industrias civis e militares. $\mathrm{O}$ concreto convencional pode resistir até 60MPa; o CAD atinge resistências entre $60 \mathrm{MPa}$ e $120 \mathrm{MPa}$, e o CPR está numa faixa de resistência à compressão entre 200MPa e 800MPa.

Composto basicamente de pós (areia de quartzo, cimento comum, pó de quartzo e sílica ativa), fibras de aço de pequenas dimensões, superplastificante e água, onde os sólidos possuem tamanhos inferiores a $2 \mathrm{~mm}$, os CPR são fabricados em condições semelhantes aos concretos convencionais, porém com baixíssima relação água/cimento - cerca de 0,15.

As propriedades de resistência do CPR o colocam em situação entre o concreto e o aço, obrigando os projetistas a repensarem as formas estruturais e as metodologias de projeto e dimensionamento para possibilitar o melhor aproveitamento do material, já que as qualidades mecânicas do CPR permitem realizar estruturas ou peças com grande liberdade de definição geométrica. Para as estruturas já construídas com CPR, como é o caso da passarela feita em Sherbrooke no Canadá segundo AITCIN \& RICHARD (1996), as armaduras passivas - símbolo da era do concreto armado - não foram empregadas, sendo substituídas por fibras de aço de pequenas dimensões. 


\section{1- Princípios Básicos do Concreto de Pós Reativos}

RICHARD (1996) escreve que o princípio do CPR é de um material com o mínimo de defeitos, tais como microfissuras e poros, o que permite a estrutura resistir a maiores tensões. Isso é possível elevando a capacidade resistente dos materiais componentes e obtendo ganho de durabilidade. Baseados nestas diretrizes, pode-se proporcionar concreto com partículas de tamanho variando de $2 \mathrm{~mm}$ a $0,5 \mu \mathrm{m}$ promovendo uma mistura de alta densidade com espaços vazios minimizados no concreto.

Para obtenção do CPR, é conveniente seguir os seguintes princípios:

- $\quad$ aumento da homogeneidade pela eliminação dos agregados graúdos;

- $\quad$ aumento da densidade pela otimização da distribuição granulométrica dos grãos e/ou aplicação de pressão no preparo;

- $\quad$ melhor microestrutura utilizando tratamento térmico durante a cura;

- $\quad$ aumento da ductilidade pela incorporação de fibras de aço;

- realizar a mistura e a moldagem de tal modo a gastar o menor tempo possível entre as operações.

A aplicação dos três primeiros princípios produz uma matriz com alta resistência àcompressão, mas com baixa ductilidade. Uma resposta a este problema é a incorporação de fibras de aço, que também impõe resistência àtração.

A homogeneidade e a densidade, dependendo da composição dos materiais, são os principais atributos do CPR. Para aumentar o desempenho pode-se, durante o processo produtivo, aplicar cura térmica e/ou pressão. A decisão na aplicação dessas medidas deve ser avaliada para cada aplicação de CPR, de acordo com as dificuldades tecnológicas envolvidas (aplicação de pressão) e/ou seus custos (cura térmica).

\subsection{1- Aumento da homogeneidade}

O concreto convencional é um material heterogêneo, onde os agregados (areia e pedra britada) forma um esqueleto de elementos granulares contínuos na pasta de cimento (cimento, aditivos e água). Mecanicamente, há diferença entre os módulos de elasticidade do agregado e da pasta; fisicamente, há diferença entre os coeficientes de expansão térmica da pasta endurecida e do agregado; e quimicamente há diferentes retrações.

Os problemas relativos à heterogeneidade são substancialmente reduzidos no CPR pelas seguintes razões: 
- $\quad$ Os agregados graúdos são eliminados e substituídos por areia fina com o tamanho dos grãos não excedendo $2 \mathrm{~mm}$. A relação entre o diâmetro máximo do agregado do CPR e do CAD é:

$$
\frac{\phi_{\max } C P R}{\phi_{\max } C A D}=\frac{1}{50} a \frac{1}{30}
$$

- $\quad$ As propriedades mecânicas da mistura são melhoradas. A relação entre os módulos de elasticidade do agregado $\left(E_{a}\right)$ e da pasta de cimento hidratado $\left(E_{p}\right)$ são:

$$
C A D: \frac{E_{a}}{E_{p}} \approx 3,0, \quad \mathrm{CPR}: \frac{E_{a}}{E_{p}}=1,0 \text { a } 1,4
$$

- A zona de transição entre o agregado e a pasta de cimento é suprimida;

- $\quad$ A relação agregado/matriz é reduzida.

\subsubsection{1- Efeito do tamanho do agregado}

Os agregados de concreto convencional são materiais rígidos. Na aplicação de forças de compressão, aparecem tensões de tração e cisalhamento na interface pasta/agregado gerando fissuras na pasta. $O$ tamanho das fissuras esta relacionado com a extensão da zona sob tensões de trações ou de cisalhamento. No caso de agregado esférico, o tamanho da fissura é diretamente proporcional ao diâmetro do agregado.

Para CPR, a redução no tamanho do agregado graúdo a um fator em torno de 50 (ex. $400 \mu \mathrm{m}$ ao invés de $20 \mathrm{~mm}$ ), provoca redução do tamanho das microfissuras de origens:

- Mecânica (carregamento externo);

- Química (retração autógena);

- Térmo - Mecânica (expansão diferenciada entre a pasta e o agregado sob efeito de tratamento térmico). 


\subsubsection{2- Efeito do aumento das propriedades mecânicas da pasta}

O CPR tem valores do módulo de elasticidade em torno de 50GPa, e podem ser maiores que 75GPa para aqueles com maiores densidades. O módulo global para a pasta e agregado é ligeiramente maior que a dos agregados de sílica. Assim os efeitos mecânicos da heterogeneidade foram removidos.

\subsubsection{3- Efeito da quantidade de areia}

Os efeitos mencionados acima são ligados ao tamanho do agregado, e pode ser descrito como "meso-efeitos". A redução da quantidade de areia representa um "macro-efeito" global.

Em concreto convencional, os agregados (areia e pedra) são os componentes majoritários em termos de volume, e forma um esqueleto rígido de elementos granulares contínuos. Neste meio é que o esqueleto granular bloqueia uma grande proporção da pasta retraída, o qual resulta em aumento de porosidade.

No caso do CPR, o volume da pasta é pelo menos $20 \%$ maior que os vazios da areia não compactada. Com isso, o agregado usado em CPR não forma um esqueleto rígido, mas um apanhado de inclusões na matriz contínua. A retração da pasta é bloqueada localmente em torno de cada partícula de agregado, enquanto que a retração global não é bloqueada pelo esqueleto rígido.

\subsection{2- Aumento da densidade}

A mistura granular composta por areia de quartzo fina, cimento, sílica ativa e pó de quartzo, é otimizada segundo as seguintes diretrizes:

- A mistura compreendendo um número de classes granulares é obtida com uma apertada distância granular dentro de cada classe;

- É estudada a compatibilidade entre o cimento e o superplastificante, e taxas ótimas são determinadas pela análise reológica;

- Condições de misturas são otimizadas.

A densidade relativa é definida em termos globais pela qualidade da mistura granular, quantidade de água, mistura e vibração eficiente. A figura 2.1 mostra valores de resistências àcompressão obtidas em modelos de CPR com diferentes valores de densidade relativa, com e sem fibras, com tratamento a temperatura ambiente e a $90^{\circ} \mathrm{C}$. As composições das misturas estão indicadas na tabela 2.1 . 
Tabela 2.1- Composição típica do CPR (em massa).

\begin{tabular}{|c|c|c|c|c|c|c|}
\hline \multirow[b]{2}{*}{ Materiais } & \multicolumn{4}{|c|}{ RPC 200} & \multicolumn{2}{|c|}{ RPC 800 } \\
\hline & \multicolumn{2}{|c|}{ Sem fibras } & \multicolumn{2}{|c|}{ Com fibras } & $\begin{array}{c}\text { Agregado de } \\
\text { Súlica }\end{array}$ & Agregado \\
\hline Cimento Portland & 1 & 1 & 1 & 1 & 1 & 1 \\
\hline Sílica Ativa & 0,25 & 0,23 & 0,25 & 0,23 & 0,23 & 0,23 \\
\hline Areia & 1,1 & 1,1 & 1,1 & 1,1 & 0,5 & - \\
\hline Pó de Quartzo & - & 0,39 & - & 0,39 & 0,39 & 0,39 \\
\hline Superplastificante (Polyacrylato) & 0,016 & 0,019 & 0,016 & 0,019 & 0,019 & 0,019 \\
\hline Fibra de aço $\mathrm{L}=12 \mathrm{~mm}$ & - & - & 0,175 & 0,175 & - & - \\
\hline Fibra de aço $\mathrm{L}=3 \mathrm{~mm}$ & - & - & - & - & 0,63 & 0,63 \\
\hline Agregado de aço & - & - & - & - & - & 1,49 \\
\hline Água & 0,15 & 0,17 & 0,17 & 0,19 & 0,19 & 0,19 \\
\hline Pressão de compactação & - & - & - & - & $50 \mathrm{MPa}$ & $50 \mathrm{Mpa}$ \\
\hline Temperatura do tratamento térmico & $20^{\circ} \mathrm{C}$ & $90^{\circ} \mathrm{C}$ & $20^{\circ} \mathrm{C}$ & $90^{\circ} \mathrm{C}$ & $250-400^{\circ} \mathrm{C}$ & $250-400^{\circ} \mathrm{C}$ \\
\hline
\end{tabular}

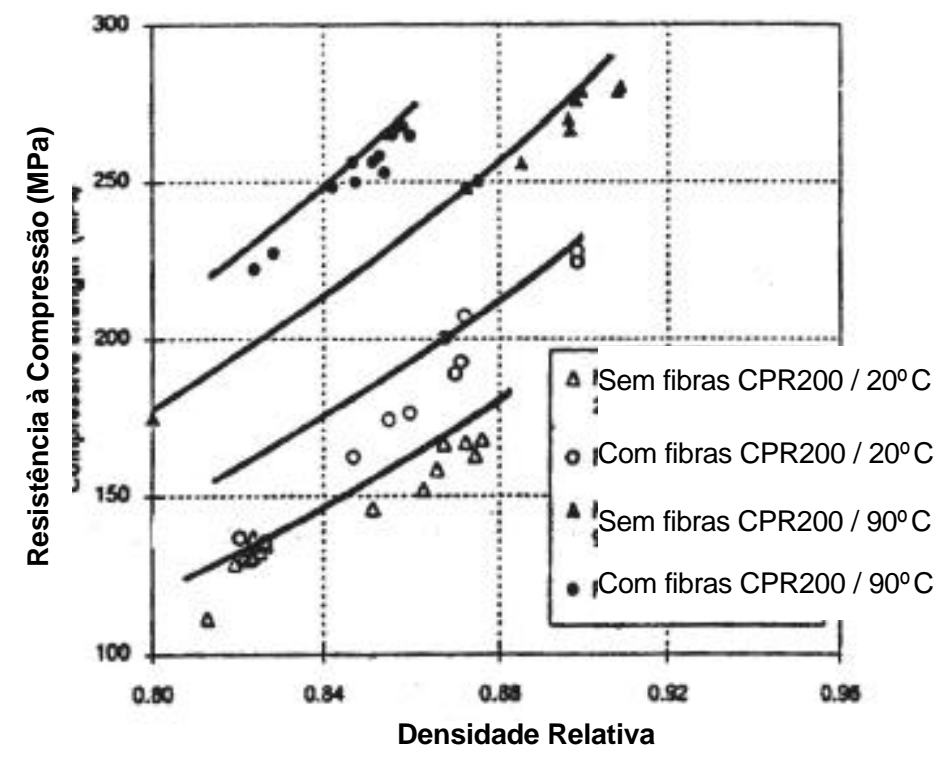

Figura 2.1 - Relação dos valores ótimos de resistências obtidos para diferentes densidades relativas [RICHARD \& CHEYREZY (1995)].

Um modo efetivo de aumentar a densidade (e a resistência à compressão) é aplicar pressão de confinamento no concreto fresco antes e durante a concretagem. Esta aplicação de pressão tem três efeitos favoráveis, de acordo com o método e intensidade da aplicação:

1) Redução do ar incorporado:

A aplicação de pressão diminui consideravelmente as bolhas de ar em poucos segundos.

2) Remoção do excesso de água:

Se a pressão for aplicada por alguns minutos no concreto fresco no qual a fôrma não é totalmente à prova d'água, a água é expelida pelos cantos da fôrma. Estes devem ser suficientemente estreitos para impedir a extrusão 
das finíssimas partícula sólidas. A eficiência do mecanismo é verificada simplesmente pela inspeção visual da exudação, o qual deve permanecer clara. Segundo RICHARD \& CHEYREZY (1995), aplicando pressão de 50MPa em corpos-de-prova de $7 \mathrm{~cm}$ de diâmetro por 30 minutos, pode-se eliminar entre $20 \%$ a $25 \%$ da água inicial introduzida durante a mistura. Este resultado é altamente significante pois diminui o fator água/cimento do CPR, e corresponde a um aumento de mais de $2 \%$ na densidade relativa.

3) Compensação da retração química

Se a pressão aplicada for mantida entre $6 \mathrm{~h}$ e 12h após a mistura ao longo da fase de moldagem do concreto, parte da porosidade do modelo resultante da retração química pode ser eliminada. A pressão aplicada durante a moldagem induz microfissuras no modelo, identificada medindo o módulo de elasticidade dinâmico. Estas microfissuras são devido a fratura das pontes rígidas criadas durante a moldagem, e expansão do agregado quando a pressão é liberada.

Resumindo, os efeitos descritos acima conduzem a um ganho de densidade relativa acima de $6 \%$. A resistência à compressão é altamente dependente da densidade relativa.

\subsection{3- Melhor microestrutura por cura térmica}

A hidratação do cimento Portland desenvolve calor caracterizando-se, assim, como reação exotérmica. Logo, o concreto no estado fresco produz calor durante sua pega e endurecimento. A quantidade de calor é dependente da quantidade de cimento que sofre hidratação, assim, quanto maior a quantidade de partículas de cimento que entram em contato com a água, maior o calor desenvolvido pelo concreto. Esse calor gera aumento de temperatura no interior do concreto que, dependendo da hidratação, pode ser alta em relação æ̀s condições ambientes.

AÏ TCIN (2000) comenta que, como o concreto de alto desempenho contém mais cimento do que o concreto usual, é necessário ter alguma preocupação com a elevação da temperatura ou gradientes térmicos excessivos no interior de elementos estruturais. Esse aumento de temperatura leva a três preocupações:

- diferentes condições de hidratação entre o concreto no elemento estrutural e os corpos-de-prova usados para controlar suas propriedades; 
- a temperatura não é uniforme na massa de concreto, de tal modo que o concreto não endurece em todos os lugares com a mesma velocidade e com a mesma temperatura máxima;

- um aumento excessivo de temperatura durante a fase inicial de endurecimento, pode gerar grandes gradientes térmicos quando o concreto se resfria até a temperatura ambiente, provocando tensões de tração que podem causar microfissuras, se essas tensões forem maiores do que a resistência àtração do concreto naquele instante.

A elevação da temperatura acelera as reações químicas de hidratação do cimento, favorecendo as propriedades mecânicas iniciais do concreto. Segundo NEVILLE (1997), temperaturas mais altas durante e depois do contato inicial entre o cimento e a água, fazem com que a estrutura total da pasta de cimento hidratada se defina mais cedo. No entanto, embora aumentem as resistências as primeiras idades dos concretos de resistência usual, isso pode prejudicar as resistências após os 7 dias de idade. NEVILLE (1997) ainda explica que a hidratação inicial rápida aparentemente forma produtos com uma estrutura fisicamente mais pobre, provavelmente mais porosa, de modo que uma fração de poros permanecerá não preenchida em concreto de resistências usuais.

\subsubsection{1- Cura térmica em concreto de pós reativos}

De acordo com pesquisas feitas com concretos de pós reativos, o efeito da cura térmica é, na maioria dos casos, benéfica na melhora das propriedades mecânicas, pois conduz a uma melhor cristalização dos hidratos e ativação da reação pozolânica da sílica ativa. Os motivos dessa melhora não estão ainda claros. No entanto, sabe-se que, sob condições térmicas, além da desidratação da pasta aglomerante endurecida, a reação da cal com a sílica ativa conduz à formação de cristais como "tobermorite" a temperaturas menores que $200^{\circ} \mathrm{C}$ e de "truscottite, gyrolite, xonotlite e hillebrandite" a altas temperaturas, dependendo da relação $\mathrm{cal} /$ sílica ativa.

RICHARD \& CHEYREZY (1995b) observaram a formação de hidratos cristalinos nos concretos de pós reativos quando submetidos a tratamento térmico e perceberam que essa técnica constitui uma maneira de melhorar as propriedades mecânicas desse material. O tratamento é realizado após o fim da pega do cimento sob pressão atmosférica e em ambiente úmido (vapor d'água) ou seco (ar quente). Esta pesquisa baseou-se em três princípios na procura das condições de cura ótima: 
- obtenção da porcentagem ótima de hidratos cristalinos;

- definição de condições estequiométricas e termodinâmicas privilegiando a formação de hidratos cristalinos, obtendo as melhores propriedades mecânicas;

- $\quad$ extração da quantidade máxima de água do concreto endurecido.

É observado, em concretos tradicionais, que sua resistência àcompressão não depende somente da porosidade total da pasta de cimento, mas também da estrutura amorfa ou cristalina dos produtos de hidratação da pasta de cimento endurecido. A transformação de hidratos amorfos em hidratos cristalinos é efetuada pelo aquecimento em condições hidrotérmicas, sendo que para uma dada temperatura a produção de hidratos cristalinos aumenta quando a porosidade diminui. RICHARD \& CHEYREZY (1995b) realizaram ensaios experimentais com concretos de pós reativos que comprovaram a sinergia entre a aplicação de pressão de compressão e um tratamento térmico à temperatura elevada, concluindo que não é proveitoso aplicar temperaturas além de $90^{\circ} \mathrm{C}$ em modelos que não são comprimidos antes da pega do cimento; e que não se alcança boas melhoras nas propriedades mecânicas em modelos comprimidos e tratados àtemperatura de $90^{\circ} \mathrm{C}$ ou inferiores.

Em ensaios experimentais por meio de análise por difração de raios-X e termogravimetria, RICHARD \& CHEYREZY (1995b) confirmaram a presença do hidrato cristalino xonotlite nos modelos tratados à temperatura de $250^{\circ} \mathrm{C}$, e não foi possível identificar a tobermorite nos modelos tratados a $200^{\circ} \mathrm{C}$, mas pode-se alertar para uma suspeita de presença da tobermorite microcristalizada, pois observou-se uma dilatação residual após o resfriamento do modelo tratado a $200^{\circ} \mathrm{C}$ para a temperatura de $20^{\circ} \mathrm{C}$ o qual também pode ser provocada por microfissuração, por compostos semicristalinos muito próximos ou até mesmo pela formação de etringita secundária formada no resfriamento que pode contribuir para a expansão observada.

A extração da água livre em concretos tradicionais, bem como em concreto de pós reativos, por secagem em ambiente seco ou por aquecimento, se traduz por um aumento da resistência à compressão e uma diminuição do módulo de elasticidade. Entretanto, para tratamentos a temperaturas de $500^{\circ} \mathrm{C}$ ou superiores, a secagem do concreto permanece, mas a resistência àcompressão diminui pois ocorre degradação do modelo por uma forte expansão residual.

CHEYREZY et al. (1995) estudaram a microestrutura e propriedades mecânicas do concreto de pós reativos por análise termogravimétrica e difração de raio- $X$, variando a temperatura de tratamento térmico e pressão aplicada ao concreto antes e durante a moldagem. Foi mostrada que as propriedades do concreto de pós reativos são altamente dependentes do tratamento térmico. 
Utilizando a técnica ${ }^{29} \mathrm{Si}$ NMR, ZANNI et al. (1996) estudaram a reação de hidratação, a média estatística do comprimento da cadeia de hidratos C-S-H e a reação pozolânica com a sílica ativa e o pó de quartzo em concreto de pós reativos. Para isso, variou-se a temperatura da cura térmica, que foi de $20^{\circ} \mathrm{C}, 90^{\circ} \mathrm{C}, 200^{\circ} \mathrm{C}$ e $250^{\circ} \mathrm{C}$, e o tempo de duração.

Como resultados, percebeu-se que a média estatística do comprimento da cadeia de C-S-H aumenta com a temperatura, modificando a microestrutura do concreto de pós reativo em temperaturas acima de $200^{\circ} \mathrm{C}$, quando comparada com aquelas entre $20^{\circ} \mathrm{C}$ e $90^{\circ} \mathrm{C}$. A atividade pozolânica da sílica ativa e do pó de quartzo são altamente acelerada pelo aumento da temperatura da cura térmica, sendo a sílica ativa mais reativa. A duração do tratamento térmico é também muito importante na hidratação e na atividade pozolânica.

Com tratamento térmico a $20^{\circ} \mathrm{C}$, e mesmo após aos 28 dias, a cadeia de C-S-H foi muito pequena e a reação pozolânica foi fraca e lenta. $A 90^{\circ} \mathrm{C}$, a duração da cura térmica foi muito importante, onde períodos maiores conduziram a longas cadeias de C-S-H e aumento da atividade pozolânica.

DUGAT et al. (1995) em seus ensaios para obtenção de CPR200, aplicou cura térmica da seguinte maneira:

- $\quad$ após a desmoldagem, o concreto foi colocado submerso em água a $20^{\circ} \mathrm{C}$ durante 7 dias;

- depois aplicou-se vapor de água a $90^{\circ} \mathrm{C}$ por 4 dias;

- $\quad$ em seguida, ar seco a $90^{\circ} \mathrm{C}$ por 2 dias.

BEHLOUL (1995) moldou vigas protendidas em CPR. A pré-tração foi liberada após 4 dias da data de concretagem. Aos 7 dias foi aplicado cura com vapor de água a uma temperatura de $80^{\circ} \mathrm{C}$ durante 5 dias, sendo que o concreto alcançou a resistência àcompressão de $170 \mathrm{MPa}$.

ADELINE \& BEHLOUL (1996) mostram, na figura 2.2, a evolução da resistência à compressão versus a duração e a temperatura do tratamento após a desmoldagem do CPR. Nesta pesquisa, o CPR foi submetido a cura térmica com 48 horas de idade nas temperaturas de $60^{\circ} \mathrm{C}, 75^{\circ} \mathrm{C}$ e $90^{\circ} \mathrm{C}$. Detectou-se que quanto maior a temperatura e o tempo de duração, maior a resistência à compressão. Percebeu-se também que após 2 dias de cura, a resistência evolui mais lentamente. 


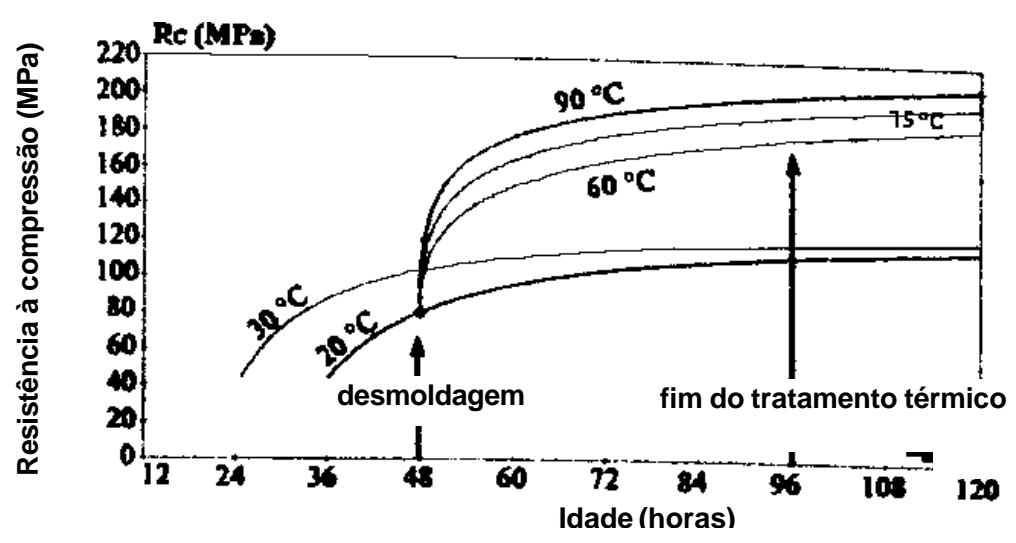

Figura 2.2- Evolução da resistência à compressão do CPR versus a temperatura e duração do tratamento térmico [ADELINE \& BEHLOUL(1996)]

\subsection{4- Aumento de ductilidade pela adição de fibras}

O comportamento do CPR, sem fibras, é elástico linear e resulta em baixa energia de fratura, não excedendo $30 \mathrm{kJm}^{-2}$. Para melhorar a ductilidade desse material, faz-se o uso de fibras metálicas onde os parâmetros para definir a escolha das fibras são: a natureza da fibra; o comprimento; o diâmetro; a forma e/ou ancoragem nas extremidades; e a dosagem.

As fibras devem ter módulo de elasticidade elevado, o que conduz a preferência por fibras metálicas a fibras de carbono ou de polímeros.

De acordo com RICHARD \& CHEYREZY (1995b), a dosagem de fibras é definida de modo experimental e geralmente são introduzidas na mistura em taxas entre $1,5 \%$ e $3 \%$ do volume de concreto. A taxa ótima econômica é $2 \%$ ou aproximadamente $155 \mathrm{~kg} / \mathrm{m}^{3}$.

O material exibe alta energia de fratura, como mostra a tabela 2.2.

Tabela 2.2- Energia de fratura de diferentes materiais.

\begin{tabular}{c|c}
\hline Materiais & Energia de Fratura $\left(\mathrm{J} / \mathrm{m}^{2}\right)$ \\
\hline Vidro & 5 \\
\hline Cerâmica e Rochas & $<100$ \\
\hline Concreto & 120 \\
\hline Metais & $>10.000$ \\
\hline CPR & 30.000 \\
\hline Aço & 100.000 \\
\hline Fonte: RICHARD (1996)
\end{tabular}

Para CPR 800 , com tratamento térmico de $250^{\circ} \mathrm{C}$, ou acima disto, o aumento do desempenho mecânico (resistência à tração e à compressão) é obtido com fibras curtas (menos que $3 \mathrm{~mm}$ ) de forma irregular. Neste caso, as energias de fratura obtidas são nitidamente reduzidas, enquanto a resistência à compressão aumentada. RICHARD \& CHEYREZY (1995b) obteve resistência à compressão de 810MPa em 
corpos-de-prova de $6 \mathrm{~cm}$ de diâmetro, com CPR incorporando agregados de aço. Resultados intermediários foram obtidos misturando dois tipos de fibras.

\section{2- Materiais Componentes do Concreto de Pós Reativos}

Para o CPR são usados os seguintes componentes granulares: areia fina de quartzo; cimento Portland; superplastificante; pó de quartzo e sílica ativa. As fibras de aço constituem uma inclusão especial.

\subsection{1- Areia}

Os parâmetros que definem a seleção da areia são: composição mineral, diâmetro médio das partículas, composição granulométrica, forma das partículas, dosagem da mistura em massa.

No que concerne a composição mineral, o quartzo oferece as seguintes vantagens: material muito duro; excelente interface pasta/agregado; boa disponibilidade e baixo custo.

É selecionada areia contendo partículas de diâmetro médio em torno de $250 \mu \mathrm{m}$. O máximo diâmetro nominal das partículas é limitado em $600 \mu \mathrm{m}$, e para o valor mínimo, tamanho de partículas abaixo de 150um são evitados. A próxima classe granular mais baixa é o cimento, para o qual o diâmetro pode variar entre $11 \mu \mathrm{m}$ e $15 \mu \mathrm{m}$.

A areia fina pode ser obtida pelo peneiramento do pó resultante da pedra britada (areia fina artificial), onde os grãos são altamente angulares, ou simplesmente extraindo areia natural com granulometria pequena, onde os grãos são mais esféricos. Ambos os tipos de areia podem ser usadas para produzir CPR. No entanto a demanda de água é ligeiramente menor para a areia natural o que é, conseqüentemente, preferível.

\subsection{2- Cimento}

A seleção do cimento não pode ser dissociada do superplastificante. Do ponto de vista da composição química, cimento com baixo conteúdo de $\mathrm{C}_{3} \mathrm{~A}$ oferece melhor resultado. Em geral, os cimentos mais finos são menos satisfatórios por conta da maior demanda de água. $O$ melhor cimento em termos das propriedades reológicas e desempenho mecânico é o cimento com alto teor de sílica. Entretanto, este tipo de cimento tem a desvantagem de ter taxa muito lenta de pega, impedindo o uso para certas aplicações. Cimento convencional de pega rápida e de alto desempenho oferece comportamento mecânico muito similar, apesar de maior demanda de água. 


\subsection{3- Superplastificante}

Atualmente existem tipos de superplastificantes identificados como de última geração. São mais eficientes e seus agentes dispersadores são àbase de poliacrilato ou policarboxilato. Os superplastificantes convencionais nacionais são selecionados pela compatibilidade com o cimento. Para CPR, as dosagens experimentais feitas com os superplastificantes de última geração utilizaram taxa de $1,5 \%$ a 2,5\% do consumo de cimento, sendo mais utilizada $2 \%$.

\subsection{4- Pó de quartzo}

O pó de quartzo é um ingrediente essencial durante o tratamento térmico do CPR. A reatividade máxima durante a cura térmica é obtida para partícula de tamanho entre $5 \mu \mathrm{m}$ e $25 \mu \mathrm{m}$. O tamanho médio da partícula do pó de quartzo usado para CPR é $10 \mu \mathrm{m}$ e é, portanto, da mesma classe granular do cimento.

\subsection{5- Adições minerais}

Adições pozolânicas ultrafinas, como a sílica ativa e a cinza de casca de arroz, são bastante efetivas no aumento da resistência, pois, além do efeito químico, atuam fisicamente densificando a matriz e a zona de transição.

A sílica ativa usada em concretos de pós reativos tem três funções principais:

- $\quad$ enchimento dos vazios entre a classe de partículas de diâmetro superior (cimento);

- aumento das propriedades reológicas pelo efeito lubrificante resultante da perfeita esfericidade das partículas básicas;

- $\quad$ p $\quad$ produção de hidratos secundários pela reação pozolânica com a cal resultante da hidratação primária.

Para CPR, os melhores resultados são obtidos com sílica ativa obtida da indústria de zircônio, sendo livre de impurezas e totalmente desagregada.

Normalmente a taxa sílica/cimento usada para CPR é 0,25. Esta taxa corresponde ao empacotamento ótimo e é próximo da dosagem requerida para consumir a cal que resulta da total hidratação do cimento. Contudo, a hidratação do cimento é incompleta em CPR, e a quantidade disponível de sílica ativa é maior que a requerida pela reação pozolânica, ficando o excesso exercendo o efeito de microfiller.

A casca de arroz é a carapaça produzida durante a operação de beneficiamento do arroz colhido (palha de arroz e arroz em casca). Sendo volumosa, a casca apresenta sérios problemas de acúmulo para as centrais beneficiadoras de 
arroz. Cada tonelada de arroz em casca produz em torno de $200 \mathrm{~kg}$ de casca, que por combustão produz $40 \mathrm{~kg}$ de cinza. A cinza formada durante a queima a céu aberto ou pela combustão não controlada em fornos industriais, geralmente contém uma grande proporção de minerais de sílica não reativos tais como a cristobalita e a tridimita, e deve ser moída gerando partículas de pequenos diâmetros, de modo a desenvolver atividade pozolânica. Por outro lado, uma cinza altamente pozolânica pode ser produzida por combustão controlada quando a sílica é mantida na forma não cristalina e em estrutura celular. Amostras deste material produzidas industrialmente apresentaram áreas específicas de $50 \mathrm{~m}^{2} / \mathrm{g}$ a $60 \mathrm{~m}^{2} / \mathrm{g}$, medidas por adsorção de nitrogênio.

Não existem ainda estudos utilizando a cinza de casca de arroz para obtenção do CPR, no entanto acredita-se que trará resultados excelentes.

\subsection{6- Preparo do CPR}

Para fabricação do CPR, são necessárias alguns cuidados no processo do preparo, principalmente quanto ao tempo de mistura, que são indispensáveis para obter o CPR de qualidade constante. A água deve ser dosada com grande precisão para obedecer a baixa relação água/cimento, determinando a manutenção da reologia do concreto fresco (características físicas no estado plástico).

A ausência de agregados graúdos - que no concreto convencional auxilia a dispersão do cimento e outros finos - é substituída pelo uso de misturador forçado, um importante dispersador de pós. Já a produção do CPR em caminhões betoneiras, embora perfeitamente possível, requer um tempo de rotação (mistura) mais elevado, ou pré-mistura do material seco. O ciclo de mistura do CPR obedece a seguinte ordem: homogeneização do material seco; fluidificação da pasta pela adição dos aditivos e da água de hidratação, adição das fibras após homogeneização da pasta fluida. A dispersão das fibras é simplificada pela utilização de dosadores vibratórios ou, também, na mistura como material seco.

\section{3- Propriedades do Concreto de Pós Reativos}

O CPR tem propriedades mecânicas elevadas, como a resistência à compressão em torno de três a vinte vezes maior que o concreto de alto desempenho (CAD), e a resistência àtração dez vezes maior. A adição de fibras de aço resulta em ductilidade e elevada capacidade de absorção de energia, normalmente 250 vezes maior que as do CAD. 
A análise do CPR200 na compressão simples e na flexão, em ensaios de corpos-de-prova em 3 e/ou 4 pontos permite obter os parâmetros necessários ao desenvolvimento de uma lei de comportamento do material.

\subsection{1- Resistência à compressão}

A resistência à compressão é a propriedade mecânica que serve de referência para avaliar as outras propriedades, tipo e qualidade do concreto. Para qualquer desempenho que se deseje obter em um concreto, ocorre um reflexo direto na resistência àcompressão, por isso pode-se utilizar esta propriedade para classificar o concreto, mesmo sabendo-se que para determinadas situações a resistência à compressão não é a propriedade mais importante.

O concreto de pós reativos não foge àregra, segundo RICHARD (1996) o CPR pode ser classificado em CPR200 para aqueles que apresenta resistência à compressão entre $170 \mathrm{MPa}$ e $230 \mathrm{MPa}$, e CPR800 com resistência àcompressão entre $500 \mathrm{MPa}$ e $800 \mathrm{MPa}$. As propriedades mecânicas para estas duas classes de CPR estão na tabela 2.3.

Tabela 2.3- Propriedades do CPR.

\begin{tabular}{|c|c|c|}
\hline Tipo de Tratamento & CPR 200 & CPR 800 \\
\hline Presurização pré-moldagem & Nenhuma & $10 \mathrm{MPa}$ a $50 \mathrm{MPa}$ \\
\hline Tratamento térmico $\left({ }^{\circ} \mathrm{C}\right)$ & 20 a 90 & 250 a 400 \\
\hline \multicolumn{3}{|l|}{ Propriedades } \\
\hline Resistência à compressãa (MPa) & 170 a 230 & 500 a 800 \\
\hline Resistência à tração por flexão (MPa) & 30 a 60 & 45 a 140 \\
\hline Energia de fratura $\left(\mathrm{J} / \mathrm{m}^{2}\right)$ & 20.000 a 40.000 & $1.200 \mathrm{a} 20.000$ \\
\hline Módulo de Elasticidade (GPa) & 50 a 60 & 65 a 75 \\
\hline
\end{tabular}

Fonte: RICHARD (1996)

Tal como exposto no item 2.1.2, a densidade da mistura é um fator que influencia bastante àresistência àcompressão do CPR. Esta densidade também pode ser aumentada pela aplicação de pressão no concreto antes e durante a concretagem, provocando redução do ar incorporado, remoção do excesso de água e compensação da retração química. De acordo com RICHARD \& CHEYREZY (1995), este aumento na densidade afeta diretamente a resistência àcompressão.

O tratamento térmico que se aplicou ao CPR também tem grande influência na resistência à compressão. Esse fato foi descrito no item 2.1.3, onde RICHARD \& CHEYREZY (1995b) relatam sobre a formação de cristais com o aumento da temperatura de cura, aumentando assim a resistência àcompressão.

DUGAT et al. (1995) realizaram ensaios em corpos-de-prova cilíndricos de dimensões $9 \mathrm{~cm} \times 18 \mathrm{~cm}$ para o tipo CPR200 e $7 \mathrm{~cm} \times 14 \mathrm{~cm}$ para o CPR800. Estes foram polidos nas duas extremidades com um disco de diamante, de modo que o 
defeito máximo de paralelismo entre as faces foi sempre inferior a $0,1^{\circ}$. Os corpos-deprova foram instrumentados com extensômetros elétricos para medir as deformações longitudinais e transversais, e a deformação pós-pico foi medida por transdutores de deslocamento. Os parâmetros foram medidos para três modelos por ensaio.

As curvas tensões $\mathrm{x}$ deformação longitudinais e transversais permitiram determinar a resistência à compressão $f_{c}$, o módulo de elasticidade estático $E_{c}$ e 0 limite de elasticidade linear. A deformação volumétrica $\varepsilon_{v}$ e o coeficiente de Poisson $v$ foram calculados a partir das deformações longitudinais e transversais, $\varepsilon_{\ell}$ e $\varepsilon_{t}$ :

$$
\begin{aligned}
& \varepsilon_{v}=\varepsilon_{l}+2 \cdot \varepsilon_{t} \\
& \nu=-\frac{\varepsilon_{t}}{\varepsilon_{l}}
\end{aligned}
$$

Na pesquisa, DUGAT et al. (1995) constataram que os CPR200 e CPR800 tiveram comportamento diferentes na compressão simples. Um exemplo de curva tensão x deformação é mostrado para CPR200 na figura 2.3. O módulo de elasticidade $E_{c}$, calculado pela deformação longitudinal medida por extensômetros na parte elástica linear da curva foi de 64GPa, o coeficiente de Poisson correspondente foi igual a 0,22. O módulo dinâmico calculado pela frequência de ressonância medida nos modelos foi igual a 60GPa com um coeficiente de Poisson de 0,23. O limite de elasticidade linear foi de $60 \%$ da resistência última. A ruptura se deu àtensão de compressão média de 200MPa.

As curvas tensão $\mathrm{x}$ deformação do CPR800 prensado durante a cura $\mathrm{e}$ submetido a tratamento térmico com altas temperaturas, mostraram diferenças de comportamento em relação ao CPR200. O material CPR800 não apresentou comportamento elástico linear mas, elástico "enrijecedor". Seu módulo de elasticidade aumentou progressivamente, passando de 32GPa para 71GPa na fase elástica linear que começou entre 5\% e 10\% da tensão última. O coeficiente de Poisson passou de 0,19 para 0,28 na fase elástica linear. A danificação acompanhada de uma diminuição do módulo de elasticidade não chegou a ser sentida até $85 \%$ da força última. $O$ comportamento "enrijecedor" do material é explicado por DUGAT et al. (1995) pelo fechamento dos poros abertos no instante do tratamento térmico a altas temperaturas. $O$ ponto $D$ da curva de deformação volumétrica, figura 2.4 , indica a mudança de compressibilidade do CPR800. Nenhuma deformação residual permanente foi observada durante o ciclo de descarregamento a $20 \%$ da força última. O módulo de elasticidade dinâmico, que é o módulo tangente na origem da curva tensão $x$ deformação, de 34GPa confirma a medida estática. 


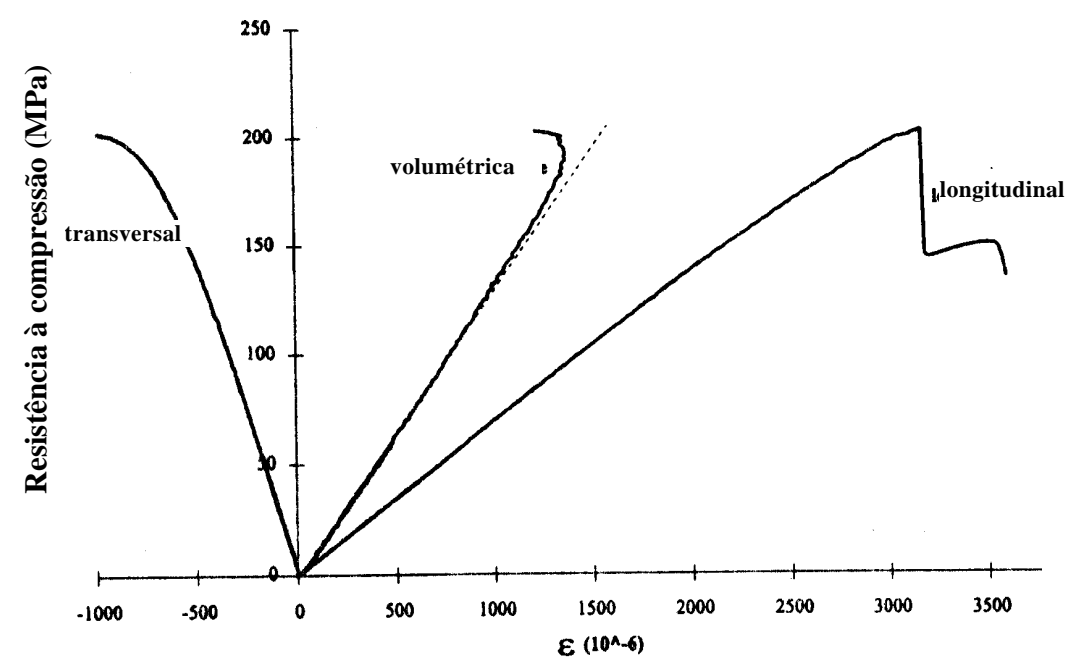

Figura 2.3- Curva tensão $x$ deformação (longitudinal, transversal e volumétrica) para CPR200 sob compressão simples. [DUGAT et al. (1995)]

DUGAT et al. (1995) ainda sugere que o comportamento "enrijecedor" do CPR800 deve ser levado em conta para o cálculo de elementos de estruturas, em particular, se estes forem protendidos. Uma lei de comportamento bilinear permite projetar simplesmente a fase de endurecimento.

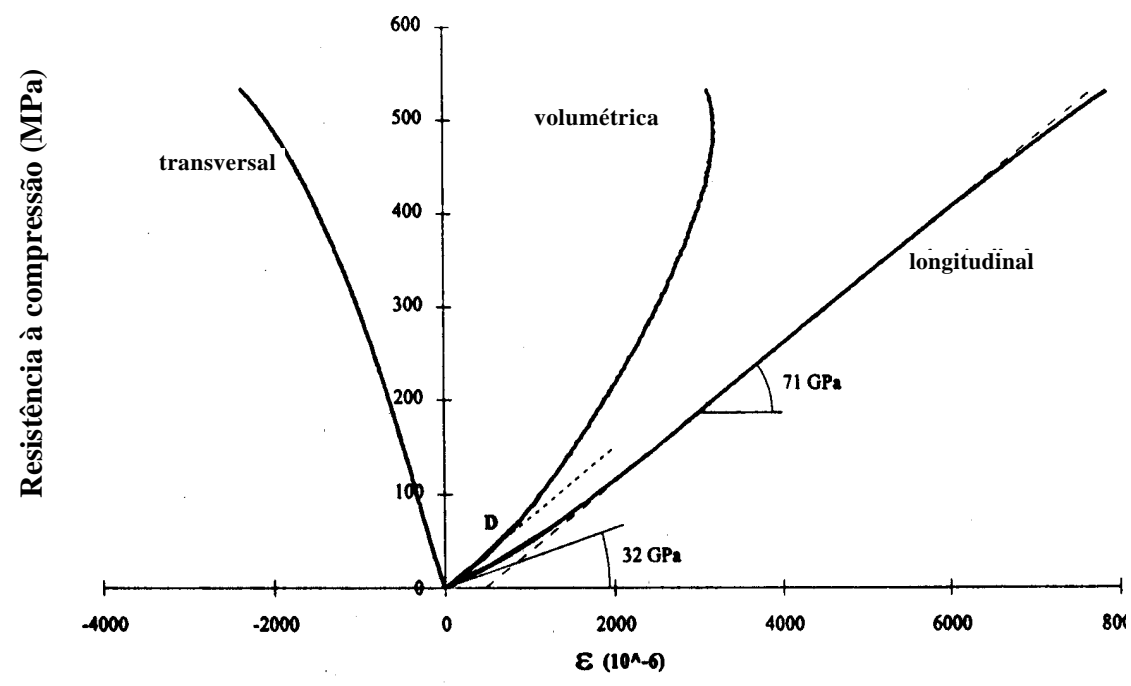

Figura 2.4- Curva tensão $x$ deformação (longitudinal, transversal e volumétrica) para CPR800 sob compressão simples. [DUGAT et al. (1995)]

As principais propriedades mecânicas medidas na compressão simples do CPR200 e CPR800 estão resumidas na tabela 2.4 . 
Tabela 2.4 - Propriedades mecânicas na compressão simples do CPR.

\begin{tabular}{l|c|c}
\multicolumn{1}{c|}{ Características Mecânicas } & $\boldsymbol{C P R} \mathbf{2 0 0}$ & $\boldsymbol{C P R} \mathbf{8 0 0}$ \\
\hline Resistência à compressão $\boldsymbol{f}_{\boldsymbol{c}}(\mathbf{M P a})$ & $194-203$ & $422-520$ \\
\hline Módulo de elasticidade estático na origem $\boldsymbol{E}_{\boldsymbol{o}}(\mathbf{G P a})$ & - & $29-36$ \\
\hline Módulo de elasticidade estático na parte linear $\boldsymbol{E}_{\boldsymbol{c}}(\mathbf{G P a})$ & $62-66$ & $63-74$ \\
\hline Módulo de elasticidade dinâmico $\boldsymbol{E}_{\boldsymbol{d i n}}(\mathbf{G P a})$ & $59-61$ & $32-36$ \\
\hline Coeficiente de Poisson estático $\mathbf{v}_{\text {est }}$ & $0,22-0,24$ & $0,19-0,28$ \\
\hline Coeficiente de Poisson dinâmico $\mathbf{v}_{\text {din }}$ & $0,22-0,24$ & - \\
\hline Limite de elasticidade linear em $\%$ da resistência última & $60 \%$ & - \\
\hline Fonte: DUGAT et al. (1995) & &
\end{tabular}

BEHLOUL et al. (1996), em estudo sobre propriedades do CPR, verificou que a resistência àcompressão não teve grande influência com a adição de fibras metálicas.

BONNEAU et al. (1996) realizou ensaios à compressão axial em CPR com e sem fibras, confinamento e aplicação de pressão. Os resultados das propriedades mecânicas são mostrados na tabela 2.5 .

Tabela 2.5- Propriedades mecânicas dos ensaios de

\begin{tabular}{|c|c|c|c|}
\hline \multirow{2}{*}{ Propriedades } & \multicolumn{2}{|c|}{ Mistura 1} & Mistura 2 \\
\hline & Sem fibras & \multicolumn{2}{|c|}{ Com fibras } \\
\hline $\begin{array}{l}\text { Resistência à compressão (MPa) } \\
\text { (coeficiente de variação - MPa) }\end{array}$ & $\begin{array}{c}163 \\
(4,0) \\
\end{array}$ & $\begin{array}{c}217 \\
(11,0) \\
\end{array}$ & $\begin{array}{r}197 \\
(9,0) \\
\end{array}$ \\
\hline Módulo de Elasticidade (GPa) & 46 & 49 & 49 \\
\hline Coeficiente de Poisson & 0,19 & 0,19 & 0,19 \\
\hline
\end{tabular}

Fonte: BONNEAU et al. (1996)

DALLAIRE et al. (1996) estudou o comportamento mecânico de 12 colunas de tubos de aço preenchidos com CPR com e sem adição de fibras metálicas e aplicação de pressão. Neste estudo chegou-se as seguintes conclusões:

- $\quad 0$ confinamento aumenta substancialmente a resistência à compressão do elemento estrutural;

- $\quad$ o confinamento é mais eficiente que o uso de microfibras metálicas para aumentar a ductilidade da estrutura.

\subsection{2- Resistência à tração}

A resistência àtração do concreto pode ser determinada por três maneiras:

- resistência à tração por compressão diametral de corpos-de-prova cilíndricos de concreto;

- resistência à tração na flexão, onde se aplica ação concentrada em um prisma de concreto, a ação pode ser aplicada no centro do vão ou terços;

- resistência àtração direta. 
Segundo BEHLOUL et al. (1996), a adição de fibras melhora o comportamento mecânico com relação à ductilidade. Esta melhora depende da natureza da matriz e do tipo de fibra. A quantidade de fibra pode chegar a $12 \%$ do volume, neste caso, a resistência àtração na flexão da matriz é aumentada substancialmente.

Para estes compostos, o comportamento àtração é importante o bastante para não ser ignorado no dimensionamento da estrutura.

BEHLOUL et al. (1996) ensaiou modelos de CPR àtração direta e variou a taxa de fibras em $0 \%, 1 \%, 2,4 \%$ e $4 \%$. Os ensaios com $0 \%$ de fibra apresentaram um comportamento frágil, as fissuras se formaram sempre diretamente e perpendicular ao eixo principal do corpo-de-prova. Os ensaios realizados com fibras tiveram comportamento dúctil. Com qualquer quantidade de fibras, pode-se perceber três fases: uma elástica linear até $70 \%$ ou $90 \%$ da força máxima, uma fase de encruamento até a força máxima, e uma fase de amolecimento onde a tensão decresce com abertura da fissura principal.

A tabela 2.6 apresenta propriedades mecânicas do CPR com diferentes quantidades de fibra: $f_{t}$ representa a resistência à tração, $f_{c}$ representa a resistência à compressão, $f_{f}$ representa a resistência àflexão e $E$ o módulo de elasticidade.

Tabela 2.6- Propriedades mecânicas do CPR para diferentes quantidades de fibras.

\begin{tabular}{c|c|c|c|c}
\hline $\begin{array}{c}\text { Quantidade de } \\
\text { Fibras }\end{array}$ & $\begin{array}{c}\mathbf{f}_{\mathbf{t}} \\
\mathbf{M P a}\end{array}$ & $\begin{array}{c}\mathbf{f}_{\mathbf{c}} \\
\mathbf{M P a}\end{array}$ & $\begin{array}{c}\mathbf{f}_{\mathbf{f}} \\
\mathbf{M P a}\end{array}$ & $\begin{array}{c}\mathbf{E} \\
\mathbf{G P a}\end{array}$ \\
\hline $\mathbf{0 \%}$ & 5,1 & 208 & 11,3 & 40,6 \\
\hline $\mathbf{1 \%}$ & 7,5 & 216 & 24,0 & 39,6 \\
\hline $\mathbf{2 , 4 \%}$ & 7,8 & 225 & 36,8 & 43,0 \\
\hline $\mathbf{4 \%}$ & 11,4 & 225 & 58,0 & 43,0 \\
\hline Fonte: BEHLOUL et al. (1996)
\end{tabular}

BEHLOUL et al. (1996) mostraram na figura 2.5 a evolução da resistência à tração do CPR versus a quantidade de fibras, e levanta a hipótese que existe um volume de fibras entre $0,5 \%$ e $1 \%$ além do qual a resistência à tração aumenta linearmente e abaixo desses valores a adição de fibras na matriz não tem efeito na resistência àtração.

Este estudo sobre o comportamento à tração do CPR mostrou a importância das fibras em duas situações:

- resistência àtração: as fibras permitem duplicar a resistência com a adição de $4 \%$ de fibras;

- comportamento pós-pico: as fibras dão maior ductilidade ao material, sendo que o comportamento pós-pico é muito importante no comportamento àflexão. 


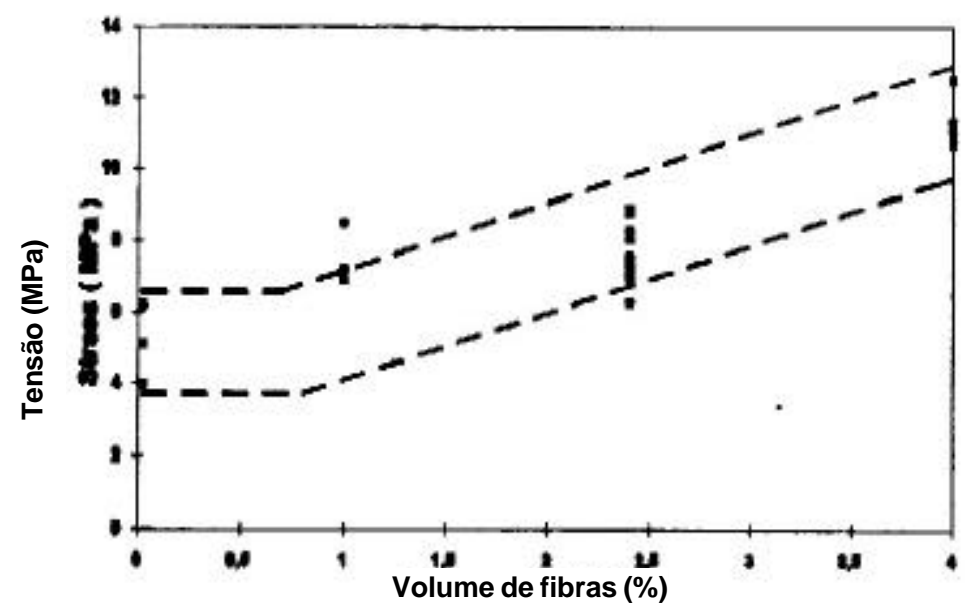

Figura 2.5- Resistência à tração para diferentes quantidades de fibras [BEHLOUL et al. (1996)]

\subsubsection{1- Aproximação probabilística para resistência à tração}

$\mathrm{Na}$ tração, o comportamento da matriz é elástico linear até o pico onde a fratura é frágil. O CPR é um material muito similar as cerâmicas, em virtude das dimensões dos grãos e a natureza da matriz. Como um material frágil, a ruptura é a conseqüência da propagação das fissuras, logo a ruptura é uma função da distribuição crítica de fissuras.

WEIBULL (1952) definiu a probabilidade de fratura em função do volume $V$ sob tensão e três parâmetros dependentes do material:

$$
P_{f}=1-e^{\left(-\iint_{V}\left(\frac{\sigma-\sigma_{u}}{\sigma_{o}}\right)^{n} d V\right)}
$$

onde "m" é o módulo de Weibull, $\sigma_{u}$ é a tensão de escoamento acima da qual a probabilidade de ruptura é igual a 1, $\sigma_{o}$ é o parâmetro de Weibull.

Muitas vezes apenas 2 parâmetros são usados, " $m$ " e " $\sigma_{o}$ ", o $\sigma_{u}$ é tomado igual a zero. No caso de tração direta, $\sigma$ é constante sobre o volume $V$ e a equação 2.5 se torna:

$$
P_{f}=1-e^{-\left(\frac{\sigma}{\sigma_{o}}\right)^{m} V}
$$

Em ensaios de tração na flexão de três pontos, a equação 2.5 se torna:

$$
P_{f}=1-e^{-\left(\frac{\sigma_{F 3}}{\sigma_{o}}\right)^{m} V_{F 3} \frac{1}{2(m+1)^{2}}}
$$

onde $\sigma_{F 3}$ é a máxima tensão no modelo (elástico linear). 
BEHLOUL et al. (1996) aplicou a equação de Weibull em matrizes de CPR sem fibras. Para isso ele identificou os parâmetros " $m$ " e " $\sigma_{o}$ " por meio da forma linearizada da equação 2.5:

$$
Y=\log \log \left(\frac{1}{1-\mathrm{P}_{\mathrm{f}}}\right)=m \cdot \log \sigma+\log \frac{V}{\sigma_{o}^{m}}
$$

Esta forma permite facilmente calcular os dois parâmetros que são os coeficientes de deformação linear o qual ajusta os pontos (Log $\sigma$, Y). Estes parâmetros podem ser medidos em ensaios a flexão em 3 pontos.

Os parâmetros de Weibull para a matriz de CPR são: $m=6$ e $\sigma_{0}=1,32$.

A média e o desvio padrão da resistência à tração pode agora ser calculada usando as fórmulas:

$$
\begin{aligned}
& \bar{f}_{t}=\sigma_{o} V^{-1 / m} \Gamma\left(1+\frac{1}{m}\right) \\
& <f_{t}>=\sigma_{o} V^{-1 / m}\left(\Gamma\left(1+\frac{2}{m}\right)-\Gamma\left(1+\frac{1}{m}\right)\right)^{1 / 2}
\end{aligned}
$$

Onde $\Gamma$ é a função gama de Euler:

$$
\Gamma(m)=\int_{o}^{\infty} e^{-t} \cdot t^{m-1} \cdot d t
$$

Aplicada ao CPR, esta fórmula conduz a resistência à tração de 4,9MPa com um desvio padrão igual a 1,15MPa. Este fornece uma boa aproximação com os valores iniciais (entre 4MPa e 6MPa)

No entanto a aproximação Weibulliana não é consistente para materiais dúcteis e especialmente CPR com fibras. Alguns autores tentam prever a resistência àtração de concreto com fibras pela modelagem micromecânica usando o comportamento da fibra em ensaios de "pull-out".

A melhor expressão conhecida, proposta por Li (1992), é:

$$
f_{t}=\frac{1}{2} \cdot g \cdot \tau \cdot V_{f} \cdot\left(\frac{L_{f}}{d_{f}}\right)
$$

onde $g$ é um fator de amortecimento, $V_{f}$ a fração de volume de fibras, $L_{f}$ e $d_{f} 0$ comprimento e diâmetro das fibras respectivamente, $\tau$ a tensão de ligação da interface fibra - matriz. 
VESTERGAARD ${ }^{2}$ apud BEHLOUL et al. (1996) encontrou uma tensão de ligação efetiva de 6MPa para matrizes comprimidas, o qual é similar ao CPR (a tensão

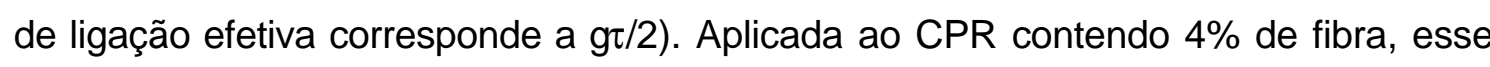
valor conduz a resistência àtração igual a 19,2MPa. Que é maior que o experimental $(11,4 \mathrm{MPa})$.

Ensaios de "pull-ouf" podem ser feitos com matrizes de CPR e fibras metálicas para identificar estes parâmetros e, eventualmente, validar esta aproximação.

\subsubsection{2- Curva tensão na tração $x$ abertura de fissura}

Com relação ao comportamento tensão na tração $x$ abertura da fissura, BEHLOUL et al. (1996) observaram que a tensão tende a zero quando a abertura da fissura principal aproximou-se de $6 \mathrm{~mm}$, que corresponde à metade do comprimento das fibras. Este comportamento foi similar em CPR com resistência àtração variando entre 6MPa e 12MPa.

Diferentes formas são propostas para descrever a curva tensão $\mathrm{x}$ abertura da fissura; as mais comuns são as curvas polinomiais de segundo grau proposta por Li (1992):

$$
\sigma(w)=\left(1-\frac{2 w}{L_{f}}\right)^{2} f_{t}
$$

ou de $3^{\circ}$ grau proposto por NAAMAN et al. (1993):

$$
\sigma(w)=\left(1-\frac{2 w}{L_{f}}\right)^{3} f_{t}
$$

wé a abertura da fissura, $L_{f}$ é o comprimento da fibra e $f_{t}$ é a resistência àtração.

A primeira fórmula superestima a tensão para pequena abertura de fissura; a segunda subestima a tensão para grande abertura de fissura.

BEHLOUL et al. (1996) propõe para CPR, a seguinte curva polinomial de $3^{\circ}$ grau:

$$
\sigma(w)=\left[-1,6 \cdot\left(\frac{2 w}{L_{f}}\right)^{3}+3,6 \cdot\left(\frac{2 w}{L_{f}}\right)^{2}-3 \cdot\left(\frac{2 w}{L_{f}}\right)+1\right] f_{t}
$$

Esta equação representou bem os resultados experimentais.

\footnotetext{
${ }^{2}$ VESTERGAARD, C. N. (1991) Tensile post-crack behaviour of steel fiber reinforced ultra highstrength concrete. Bangkok proceedings, 21 Nov.
} 


\subsection{3- Comportamento na flexão}

O estudo do comportamento à flexão de um material é feito geralmente por ensaios de corpos-de-prova prismáticos. Os corpos-de-prova podem ser carregados com uma força concentrada no meio do seu vão, com duas forças concentradas aplicadas nos terços do vão ou por várias forças concentradas distribuídas ao longo do corpo-de-prova simulando um ação uniformemente distribuída.

O ensaio à flexão com força aplicada no centro do corpo-de-prova é denominado de ensaio àflexão em 3 pontos, pois os 2 apoios e a seção de aplicação da força definem 3 pontos de aplicação de forças. O ensaio com 2 forças aplicadas nos terços do vão é denominado de ensaio à flexão em 4 pontos pelo mesmo raciocínio.

Nos ensaios àflexão pode-se medir a força máxima alcançada na ruptura dos corpos-de-prova, bem como o deslocamento vertical da seção central do modelo. Com isso, considerando os conceitos de resistência dos materiais, pode-se estimar o momento de ruptura e as tensões nas fibras tracionadas e comprimidas da seção central. A tensão de tração máxima medida nesses ensaios é denominada módulo de ruptura, e serve de parâmetro para analisar a resistência àtração do material.

O ensaio à flexão em 4 pontos é identificado por solicitar o terço central do modelo a flexão pura, livre das tensões tangenciais. Nesses ensaios pode-se medir as deformações nas faces inferior e superior por extensômetros colados nestas faces, permitindo estudar a diferença de comportamento do material na tração e na compressão.

DUGAT et al. (1995) estudou a flexão em modelos prismáticos de dimensões $5 \mathrm{~cm} \times 4 \mathrm{~cm} \times 60 \mathrm{~cm}(\mathrm{~b} \times \mathrm{h} \times \mathrm{l})$ não entalhados, carregado à flexão em quatro pontos com uma distância entre apoios de $50 \mathrm{~cm}$. Os corpos-de-prova foram solicitados a flexão pura em um terço de sua extensão. Os esforços foram transmitidos no plano de flexão, eliminando todo efeito de torção. O deslocamento vertical foi medido com transdutor de deslocamento utilizando como referência o eixo central do modelo.

Extensômetros foram colados na superfície superior e inferior do modelo. Estes permitiram acompanhar as deformações das fibras extremas do corpo-de-prova até a ruptura dos extensômetros, podendo assim identificar as deformações limites de tração para o comportamento elástico linear.

DUGAT et al. (1995) ilustra a curva experimental força $x$ deslocamento (flecha no centro) na figura 2.6, o que permitiu determinar um certo número de parâmetros: a tensão de ruptura de $22 \mathrm{MPa}$, o módulo de elasticidade na parte elástica linear igual a 43GPa e o limite de elasticidade linear a $54 \%$ da tensão última. A resistência na flexão 
medida em modelos normatizados de $4 \mathrm{~cm} \times 4 \mathrm{~cm} \times 16 \mathrm{~cm}$ em ensaios de 3 pontos foi igual a 32MPa.

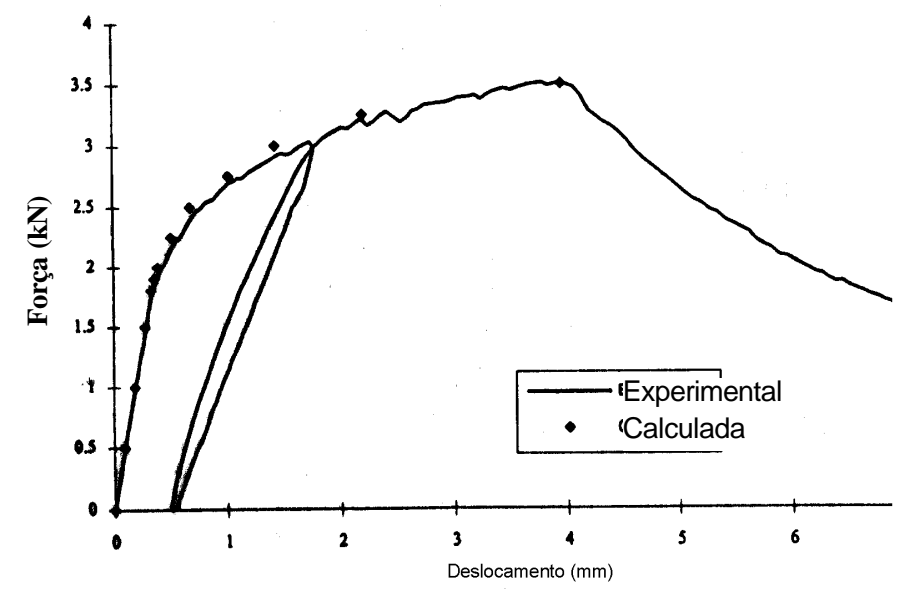

Figura 2.6- Curva força $x$ deslocamento em ensaios à flexão de 4 pontos [DUGAT et al. (1995)]

A medida das deformações na fibra superior e inferior da zona de flexão pura, mostra o mesmo tipo de comportamento na compressão e na tração até o ponto $D$ da figura 2.7.

A deformação elástica linear do CPR200 terminou em $330 \times 10^{-6} \mathrm{~m} / \mathrm{m}$. O dano progressivo na tração a partir deste ponto fez divergir a curva para direita da reta $\varepsilon_{\text {sup }}=$ $\varepsilon_{\text {inf }}$. DUGAT et al. (1995) ressalta que a microfissuração do material não levou a ruína da estrutura, o volume de fibras foi suficiente para redistribuir as tensões entre a fibra e a matriz (encruamento). Observou-se também uma localização de deformação com abertura de uma fissura única acompanhada de um comportamento de "amolecimento". A ruptura do extensômetro colado na fibra tracionada do modelo não permitiu ver a fase pós-pico na figura 2.7. A deformação última medida na flexão no CPR200 foi de $7.500 \times 10^{-6} \mathrm{~m} / \mathrm{m}$.

BEHLOUL (1995) estudou o comportamento do CPR a fim de definir uma relação tensão $x$ deformação. Para isso ele realizou ensaios para analisar as propriedades do CPR, entre eles os de flexão em 3 e 4 pontos.

Os ensaios àflexão em três pontos foram efetuados com modelos prismáticos de $4 \mathrm{~cm} \times 4 \mathrm{~cm} \times 16 \mathrm{~cm}$, esses ensaios apresentaram resistência àtração na flexão de $35 \mathrm{MPa}$ à $40 \mathrm{MPa}$. Para obter um estado de flexão pura, foram realizados ensaios de flexão em quatro pontos em modelos com espessuras de $1,5 \mathrm{~cm}$ e $2,5 \mathrm{~cm}$, largura de $10 \mathrm{~cm}$ e $40 \mathrm{~cm}$ de comprimento. Os modelos foram instrumentados com dois extensômetros colados um na face superior e outro na inferior que permitiu obter a deformação última do concreto de pós reativos de $6.000 \times 10^{-6}$. A resistência àtração na flexão medida nesses ensaios foi de 22MPa à25MPa. 


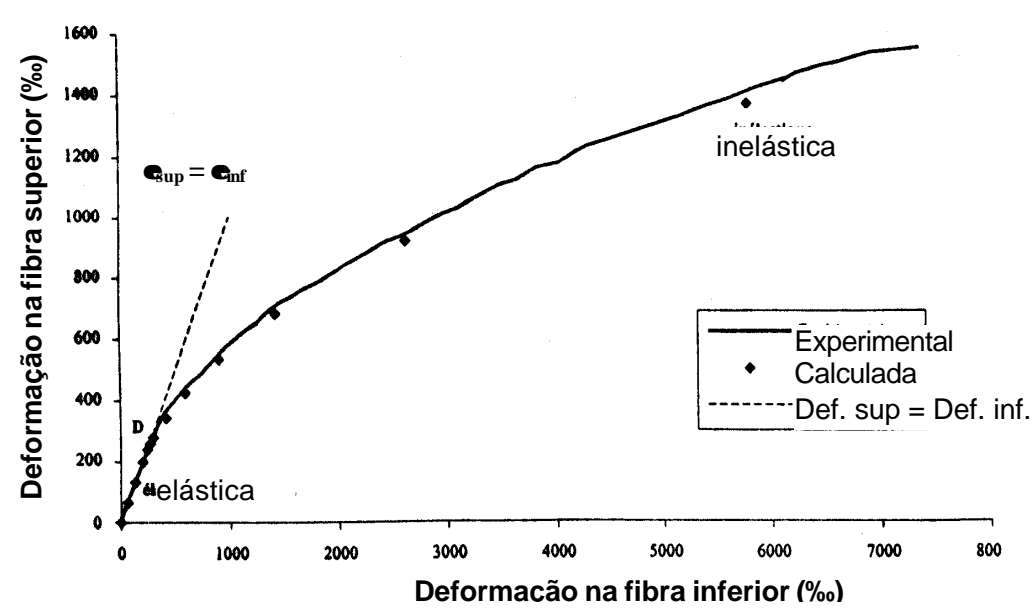

Figura 2.7- Comparação das deformações na tração e na compressão em ensaios à flexão de 4 pontos [DUGAT et al. (1995)]

BEHLOUL (1995) concluiu que a diferença entre a resistência à tração direta e a resistência à tração na flexão em três e quatro pontos resulta da justaposição de dois efeitos:

- um efeito mecânico: o comportamento do material não é elástico-linear mas elastoplástico, um coeficiente de 2,2 - 2,7 subsiste entre a flexão pura (4 pontos) e a tração direta.

- um efeito de dispersão: a flexão em três pontos solicita uma zona limite do modelo enquanto que o ensaio de flexão em quatro pontos solicita o terço do modelo e o ensaio de tração direta solicita todo o modelo. A probabilidade de encontrar uma seção mais frágil é maior nos dois últimos casos. Isto leva a uma resistência a tração por flexão em quatro pontos, inferiores aquelas obtidas por flexão em três pontos a um fator de 1,5 - 1,7 (medidos experimentalmente).

RICHARD \& CHEYREZY (1994), em estudo pioneiro sobre CPR, encontraram valores para o módulo de ruptura de $25 \mathrm{MPa}$ à 60MPa para o CPR200 e 45MPa à 102MPa para o CPR800.

BEHLOUL et al. (1996) realizou ensaios de flexão em 3 pontos para CPR com algumas taxas de fibra. Os módulos de ruptura foram aumentados de 11,3MPa para $58 \mathrm{MPa}$, de acordo com o aumento da taxa de fibras, como mostra a figura 2.8. 


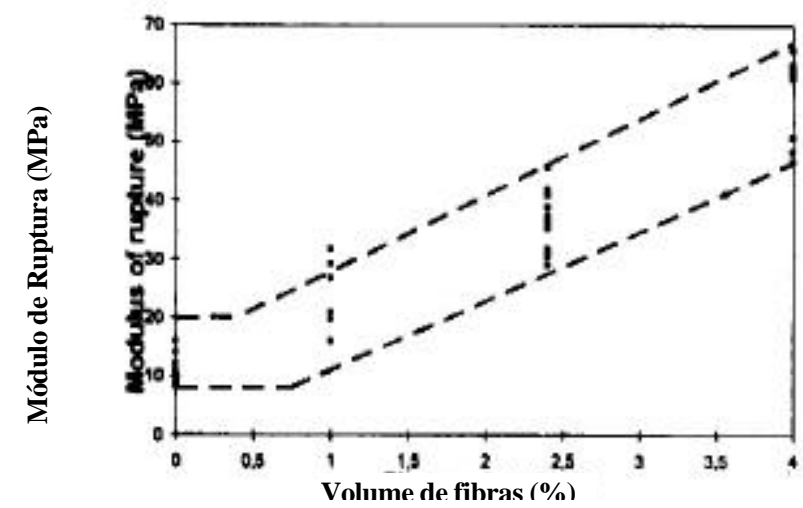

Figura 2.8- Módulo de ruptura para diferentes quantidades de fibras.

[BEHLOUL et al. (1996)]

\subsection{4- Módulo de deformação longitudinal}

O módulo de deformação longitudinal na compressão, comumente chamado de modulo de elasticidade, é medido em ensaios de compressão axial em corpos-deprova instrumentados para obtenção das deformações longitudinais até a força de ruptura.

$\mathrm{Na}$ literatura exposta nos itens anteriores relatando ensaios sobre a resistência à compressão, tração e flexão, foram medidos módulos de elasticidade do CPR. RICHARD \& CHEYREZY (1994) obteve módulos de 54GPa a 60GPa em CPR200 e de 65GPa a 75GPa em CPR800.

DUGAT et al. (1995) chegou a valores de 62GPa à 66GPa em ensaios de CPR200 e relata o comportamento do CPR800 como elástico "enrijecedor" com módulo de elasticidade aumentando progressivamente passando de 32GPa para $71 \mathrm{GPa}$ na fase elástica, permanecendo este valor até $85 \%$ da força última.

BEHLOUL et al. (1996), em ensaios com variação da taxa de fibras, mostrou que os módulos de elasticidade são um pouco mais dispersos que a resistência à compressão (o desvio padrão é igual a 4MPa para 2,4\% de fibras). Os valores médios dos resultados mostram um pequeno aumento de 40,6GPa até 43GPa; este aumento é similar ao da resistência àcompressão.

BONNEAU et al. (1996) mediu valores para o módulo de elasticidade de 46GPa em CPR sem fibras e de 49GPa em CPR com fibras.

BEHLOUL (1995), em ensaios de tração direta, analisou a curva tensão $x$ abertura de fissura e avaliou o módulo de deformação longitudinal na tração de 40GPa. Em ensaio de compressão alcançou-se o valor de 53GPa. Esta pesquisa mostra a continuidade do módulo de elasticidade entre tração e compressão antes de danificar o material e que a adição de fibras tem um ligeiro efeito no módulo de elasticidade. 


\subsection{5- Coeficiente de Poisson}

O coeficiente de Poisson "v" é um parâmetro que relaciona a deformação transversal com a longitudinal do material. A sua obtenção é feita em ensaios de compressão axial com corpos-de-prova instrumentados de modo a medir as deformações longitudinais e transversais e é calculado pela relação:

$$
v=-\frac{\varepsilon_{t}}{\varepsilon_{l}}
$$

DUGAT et al. (1995) realizou ensaios deste tipo e mediu o coeficiente de Poisson de 0,23 para o CPR200. Em CPR800, que apresentou um comportamento elástico enrijecedor, o coeficiente de Poisson passou de 0,19 para 0,28 na fase elástica.

BONNEAU et al. (1996) chegou a valores de 0,19 para o coeficiente de Poisson em CPR com resistência àcompressão entre 160MPa e 220MPa.

\subsection{6- Durabilidade do concreto de pós reativos}

O fato do concreto de pós reativos ter uma estrutura particularmente densa da pasta de cimento hidratada, com um sistema de poros descontínuos, ou seja, uma baixíssima permeabilidade, possibilita ter alta resistência ao ataque de agentes externos.

Quanto ao risco da reação alcali-sílica, pode-se esperar que este material seja particularmente resistente em virtude da baixa permeabilidade que limita a mobilidade dos íons, bem como o baixo teor de água, lembrando-se que a presença de água é fundamental para a reação álcali-sílica.

Quanto à resistência ao congelamento e ao degelo, a estrutura da pasta de cimento é tal que há pouquíssima água congelável presente.

A porosidade do CPR é identificada pelo baixo volume de poros na pasta hidratada e diâmetro dos poros menor que 5 nanometros.

O CPR apresenta resultados superiores em ambientes agressivos com ciclos de gelo e degelo, quando comparados com o concreto convencional e até mesmo CAD com ar incorporado.

A taxa de carbonatação e resistência à abrasão também compara-se favoravelmente com concreto convencional e CAD. 


\subsection{7- Lei do Comportamento do Concreto de Pós Reativos}

BEHLOUL (1995) estudou o comportamento do concreto de pós reativos em viga de tamanho real com utilização de protensão aderente, onde toda tração foi absorvida pela protensão e toda compressão pelo concreto. Ele visava analisar os dados obtidos em ensaios de modelos de pequenas dimensões e utilizá-los na análise de estruturas em escala real, definindo-se, assim, uma relação tensão $x$ deformação para concreto de pós reativos que pode ser extrapolada para modelos reais.

Para analisar as propriedades do material, foram feitos ensaios de compressão direta, flexão em três e quatro pontos e tração direta.

$\mathrm{Na}$ compressão o CPR apresentou comportamento com duas fases, uma elástica linear com módulo de elasticidade de $53 \mathrm{GPa}$, e uma segunda fase elástica não-linear até a tensão de ruptura próxima de $200 \mathrm{MPa}$.

Os ensaios àflexão em três pontos foram efetuados com modelos prismáticos de $4 \mathrm{~cm} \times 4 \mathrm{~cm} \times 16 \mathrm{~cm}$, esses ensaios apresentaram resistência àtração na flexão de $35 \mathrm{MPa}$ à 40MPa. Para obter um estado de flexão pura, foram realizados ensaios de flexão em quatro pontos em modelos com espessuras de $1,5 \mathrm{~cm}$ e $2,5 \mathrm{~cm}$, largura de $10 \mathrm{~cm}$ e $40 \mathrm{~cm}$ de comprimento. Os modelos foram instrumentados com dois extensômetros colados um na face superior e outro na inferior, que permitiu obter a deformação última do concreto de pós reativos de $6.000 \times 10^{-6}$. A resistência àtração na flexão medida nesses ensaios foi de $22 \mathrm{MPa}$ a $25 \mathrm{MPa}$.

Foram feitos ensaios àtração direta com modelos de acordo com a figura 2.9. onde os resultados obtidos apresentaram uma resistência à tração direta de 8MPa a $11 \mathrm{MPa}$. Analisando a curva tensão x abertura de fissura, permitiu-se também avaliar o módulo de deformação na tração de 40GPa.

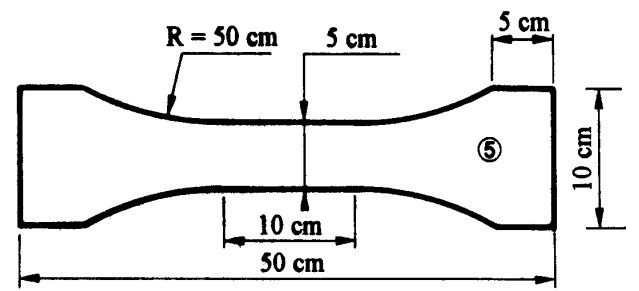

Figura 2.9 - Modelo de ensaio à tração direta [BEHLOUL (1995)]

Os ensaios descritos permitiram conhecer o comportamento do material sob diferentes solicitações: compressão, flexão e tração.

BEHLOUL (1995) sintetizou todos os resultados experimentais sob a forma de uma lei de comportamento como mostra a figura 2.10 . 


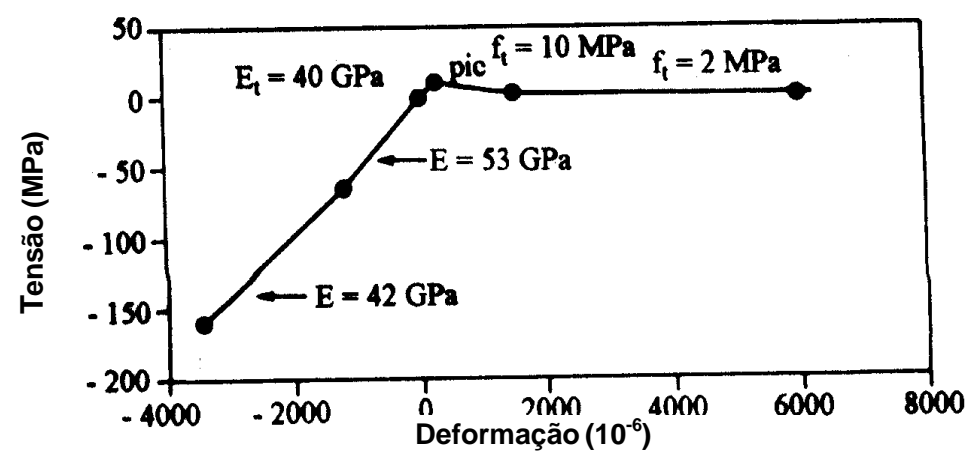

Figura 2.10 - Lei do comportamento do CPR 200 [BEHLOUL (1995)]

Na compressão, a lei do comportamento é bilinear com um módulo de 53GPa até uma tensão de $64 \mathrm{MPa}$ então um módulo de $42 \mathrm{GPa}(53 \times 0,8)$ até o valor máximo de cálculo de 160MPa.

$\mathrm{Na}$ tração, a lei do comportamento CPR envolve três fases: uma primeira fase elástica-linear até o pico onde a tensão é de 10MPa com um módulo de 40GPa seguindo uma fase com diminuição linear da tensão até $2 \mathrm{MPa}$, com uma deformação de $1500 \times 10^{-6}$; na última fase, a tensão permanece constante (2MPa) até a deformação de ruptura de $6000 \times 10^{-6}$.

Os ensaios com ciclos de carga e descarga foram necessários para conhecer a natureza do comportamento do material no instante do descarregamento: são elásticos perfeitos (deformação retorna a zero) ou elastoplásticos (deformação inelástica).

A lei do comportamento do CPR desenvolvido em BEHLOUL (1995) e BEHLOUL et al. (1996), baseada nas propriedades mecânicas medidas em corpos-deprova, necessita dos seguintes parâmetros: módulo de elasticidade E; resistência à compressão $f_{c}$; e módulo de ruptura $f_{f}$, que podem ser facilmente medidas. Assim 0 CPR é definido da seguinte maneira:

- na compressão: uma curva bilinear na qual a primeira parte tem inclinação igual a $E$ e se mantém até $40 \%$ da resistência à compressão $f_{c}$, e a segunda parte corresponde ao trecho de $40 \%$ de $f_{c}$ até $f_{c}$ com uma inclinação de 0,8E.

- na tração: uma parte linear até $f_{f} / 4,32$ com inclinação igual a 0,9E e uma parte pós-pico com uma forma cúbica.

BEHLOUL (1995) aplicou esta lei de comportamento do CPR em duas estruturas: um modelo de $2,5 \mathrm{~cm}$ de espessura, $10 \mathrm{~cm}$ de largura e $40 \mathrm{~cm}$ de comprimento submetido à flexão em 4 pontos e uma viga protendida com seção transversal em "T", comprimento total de $10 \mathrm{~m}$ e uma altura de $34 \mathrm{~cm}$. A mesa superior tem uma largura de $15 \mathrm{~cm}$ e a alma tem espessura de $6 \mathrm{~cm}$. A protensão foi realizada 
por dois cabos T15 de $139 \mathrm{~mm}^{2}$ de seção. O limite elástico do aço é de $1.525 \mathrm{MPa}$ e a tensão de ruptura é de $1.730 \mathrm{MPa}$. A viga não teve nenhuma armadura passiva.

Para os modelos pequenos de $2,5 \mathrm{~cm}$ de espessura, BEHLOUL (1995) constatou que por causa da pequena espessura do modelo, o estado de solicitação não é perturbado por modificações no campo de tensões nas vizinhanças dos apoios.

No ensaio da viga, as forças verticais foram aplicadas por intermédio de 8 atuadores hidráulicos distribuídos uniformemente. Uma face da viga foi pintada para facilitar a visualização das fissuras. Utilizou-se a lei do comportamento proposto anteriormente para estudar a evolução do deslocamento vertical em função do momento fletor na seção central da viga. A curva teórica forneceu o comportamento da viga em todas as fases:

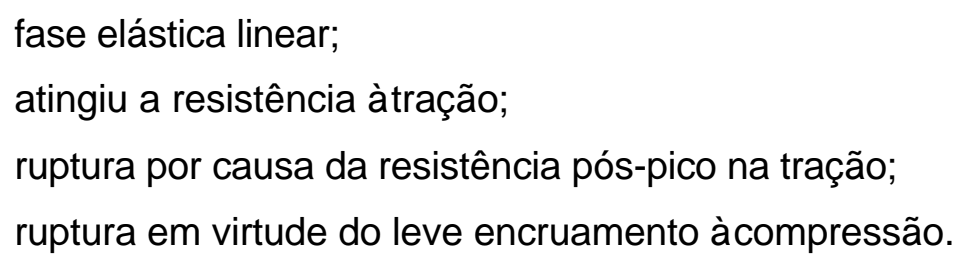

O ensaio da viga de $10 \mathrm{~m}$ mostrou um comportamento dúctil da estrutura: uma fase inicial elástica linear sem deslocamento residual no descarregamento, depois uma segunda fase não linear com múltipla fissuração distribuída. Próximo da ruína, a flecha observada foi de $1 / 30$ do comprimento. O comportamento dúctil observado nos modelos de caracterização se reproduziu na escala de estrutural real.

Com ensaios de caracterização mecânica, permitiu-se estabelecer uma lei de comportamento que pode prever o funcionamento de estruturas sob diferentes tipos de solicitações. Esta lei é aplicada em modelos de laboratório e também em estrutura de grandeza real. É necessário ainda realizar análise do comportamento no instante do descarregamento e do efeito de escala.

O estudo feito por ADELINE \& BEHLOUL (1996) analisou a lei de comportamento do CPR proposta por BEHLOUL (1995), que é baseada nas propriedades mecânicas de corpos-de-prova. A análise foi feita em modelos de escala real e estudou o comportamento estrutural do CPR.

ADELINE \& BEHLOUL (1996) ensaiaram quatro vigas de $15 \mathrm{~m}$ de comprimento, moldadas com concreto de pós reativos com fibras e sem armadura passiva, para analisar se as propriedades mecânicas medidas em modelos de pequenas dimensões podiam ser extrapoladas para modelos estruturais em escala real. Os ensaios confirmaram a grande ductilidade do material em estrutura em escala real. As leis de comportamento do CPR, definidas com base nas propriedades mecânicas de modelos reduzidos, se enquadraram bem no comportamento geral da estrutura e deu uma noção da facilidade de prever o comportamento de outras estruturas de CPR. A 
homogeneidade do CPR permite também a aplicação de grandes protensões em áreas com apenas $15 \mathrm{~mm}$ de cobrimento.

ADELINE \& BEHLOUL (1996) concluíram que a lei constitutiva do CPR, baseada nas propriedades mecânicas de corpos-de-prova, pode prever com precisão o comportamento de estruturas em escala real. Além disso foi observado:

- há viabilidade na execução de estruturas de CPR protendido sem armadura passiva;

- é possível obter CPR de 180MPa em condições industriais com um apropriado tratamento térmico;

- permite alta tensão de protensão em área com apenas $1,5 \mathrm{~cm}$ de cobrimento.

\section{4- Síntese do Estudo Bibliográfico}

O concreto de pós reativo é composto de areia de quartzo, cimento, pó de quartzo, sílica ativa, fibras de aço de pequenas dimensões, superplastificante e água, onde os sólidos possuem tamanhos variando entre $2 \mathrm{~mm}$ e $0,5 \mu \mathrm{m}$. Estes concretos podem ser fabricados em condições semelhantes aos concretos convencionais, porém com baixíssima relação água/cimento - cerca de 0,15.

Para obtenção do CPR, é conveniente seguir os seguintes princípios:

- $\quad$ aumento da homogeneidade pela eliminação dos agregados graúdos;

- $\quad$ aumento da densidade pela otimização da distribuição granulométrica dos grãos e/ou aplicação de pressão no preparo;

- fortalecimento da microestrutura utilizando tratamento térmico durante a cura;

- aumento da ductilidade pela incorporação de fibras de aço;

- realizar a mistura e a moldagem de tal modo a gastar o menor tempo possível entre as operações.

O CPR pode ser classificado em CPR200, para aqueles que apresenta resistência à compressão entre $170 \mathrm{MPa}$ e $230 \mathrm{MPa}$, e CPR800, com resistência à compressão entre 500MPa e $800 \mathrm{MPa}$.

A densidade da mistura é um fator que influencia bastante a resistência à compressão do CPR. Esta densidade pode ser aumentada por meio de uma boa composição granulométrica, e também pela aplicação de pressão no concreto antes e durante a concretagem, provocando redução do ar incorporado, remoção do excesso de água e compensação da retração química. 
O tratamento térmico tem grande influência na resistência à compressão, provocando uma microestrutura mais densa, melhorando, assim, a resistência à compressão.

A adição de fibras metálicas não apresenta grandes influências na resistência à compressão, porém melhora a ductilidade do material. Entretanto, pode-se adotar tubos metálicos preenchidos com CPR para melhorar a ductilidade.

Pesquisas mostram que a resistência àtração na flexão para o CPR200 está entre $25 \mathrm{MPa}$ e $60 \mathrm{MPa}$, e para o CPR800, esses valores ficaram entre $45 \mathrm{MPa}$ e 102MPa, dependendo da quantidade de fibras utilizada.

O módulo de elasticidade do CPR foi avaliado entre 54GPa e 60GPa para CPR200 e de 65GPa a 75GPa para CPR800, e as fibras apresentam pouca influência nesses resultados.

O coeficiente de Poisson foi avaliado entre 0,19 e 0,23 para o CPR200.

A relação constitutiva para o CPR proposta por BEHLOUL (1995), foi definida da seguinte maneira:

- na compressão: uma curva bilinear na qual a primeira parte tem inclinação igual a $E$ e se mantém até $40 \%$ da resistência à compressão $f_{c}$, e a segunda parte corresponde ao trecho de $40 \%$ de $f_{c}$ até $f_{c}$ com uma inclinação de $0,8 E$.

- $\quad$ na tração: uma parte linear até $f_{f} / 4,32$ e com inclinação igual a 0,9E e uma parte pós-pico com uma forma cúbica.

\section{Considerações Finais}

Com o estudo da bibliografia consultada percebeu-se que algumas informações ficaram obscuras e outras despertaram curiosidades, entre elas:

- O método de dosagem para a composição da mistura com maior densidade não ficou claro. Com isso, este trabalho buscou estudar um método de empacotamento que propiciasse composição granulométrica com alta densidade, e atingisse resistência à compressão próxima de 200MPa;

- No estudo da dosagem são necessários verificar a influência de alguns fatores, onde, nesse trabalho, foram analisados: a relação água/cimento, a temperatura de cura, o tempo de cura e também pré cura térmica, além do efeito das fibras na dosagem;

- a relação constitutiva para o CPR proposta por BEHLOUL (1995) era a única publicada, bem simples e de fácil utilização, mas, pela sua 
simplicidade foram levantados alguns pontos curiosos, que não foram esclarecidos em nenhum artigo publicado sobre o assunto. Alguns deles são: quais os limites máximo e mínimo para a resistência à compressão, qual a influência da quantidade de fibras na relação constitutiva; quais as deformações máximas na tração e na compressão;

- Com isso, essa pesquisa buscou elaborar uma relação constitutiva em que fosse considerada a influência das fibras, e que representasse com precisão 0 comportamento tensão $x$ deformação medidos experimentalmente;

- Percebeu-se nesses estudos bibliográficos que a resistência à flexão é influenciada pela quantidade de fibras contidas na dosagem, no entanto, essa propriedade não foi equacionada. Assim, procurou-se fazer análise dessas propriedades, onde foi proposta uma equação que relaciona a resistência àflexão com o volume de fibras;

- Outro ponto curioso percebido durante a análise bibliográfica foi a deformação máxima para o limite elástico na tração do CPR. Esse trabalho analisou as deformações de alongamento, a fim de estabelece o limite máximo para o qual o material se comportava no regime elástico para as tensões de tração. 



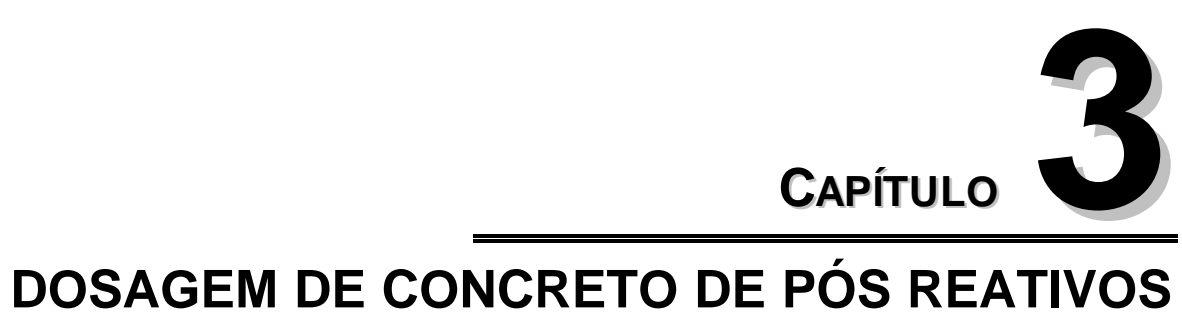

Considerações Iniciais

Neste capítulo serão analisados métodos de dosagem, a fim de obter uma composição de materiais com maior densidade. Assim, pretende-se definir uma dosagem que atingisse resistência àcompressão próximo de 200MPa, com o objetivo de utilizá-la para o estudo das propriedades mecânicas do concreto de pós reativos. 
A dosagem do concreto de pós reativos visa criar um material com o mínimo de defeitos, utilizando partículas sólidas de pequenos diâmetros, variando entre $2 \mathrm{~mm}$ e $0,5 \mu \mathrm{m}$, proporcionando mistura de alta densidade e o mínimo de vazios. Para isso, seguem-se os princípios já citados por RICHARD (1996):

- não utilização de agregados graúdos, diminuindo a heterogeneidade;

- otimização da distribuição granulométrica, aumentando a densidade;

- utilização de tratamento térmico para melhorar a microestrutura;

- incorporação de fibras metálicas para melhorar a ductilidade.

A distribuição granulométrica dos grãos que compõem o CPR é estudada de modo a obter um produto com alta densidade, onde os espaços entre as partículas maiores são preenchidos pela classe de partículas imediatamente menor e, assim sucessivamente, formando o chamado empacotamento das partículas.

O estudo do empacotamento é bastante amplo e existem alguns métodos já desenvolvidos. Como o CPR é um material de granulometria fina e também bastante compacto, ele se assemelha aos compósitos cerâmicos. Logo, o método utilizado para alcançar o empacotamento das partículas foi baseado no método de Andreassen \& Andersen comumente utilizado para a obtenção de compósitos cerâmicos. Este método e sua aplicação serão detalhados nos subitens seguintes.

\section{1- Método do Empacotamento}

A análise da distribuição dos tamanhos das partículas que compõem o material em estudo, tem se mostrado um procedimento eficiente no desenvolvimento e produção de materiais cerâmicos, principalmente na área de refratários, onde o objetivo é obter material com alta densidade. Para aumentar a densidade pode-se diminuir os espaços entre as partículas, preenchendo-os com partículas menores, procurando formar o chamado "empacotamento". No entanto, além de aumentar a densidade, é necessário obter trabalhabilidade adequada do material estudado para que se permita o manuseio e adensamento. A quantidade de água utilizada para provocar as reações químicas e obter trabalhabilidade do material, é um fator importante que pode provocar o aparecimento de poros na mistura, diminuindo assim a densidade.

Teoricamente, para alcançar um empacotamento perfeito, ou seja, $100 \%$ de densidade, não precisaria de adição de água na mistura. A combinação do perfeito empacotamento junto com boa trabalhabilidade é um paradoxo, pois a fluidez é o efeito das partículas se moverem umas em relação æ̀s outras, separadas por um líquido, sendo que sem esse líquido atuando como lubrificante o empacotamento 
perfeito torna-se contraditório com a trabalhabilidade. Logo, a diminuição da quantidade de água e o aumento da densidade se tornou a principal tarefa no desenvolvimento tecnológico dos materiais a base de cimento.

\subsection{1- Modelo teórico de empacotamento de partículas}

Para realizar o empacotamento das partículas existem alguns modelos matemáticos. MYHRE \& HUNDERE (1996) indica os modelos de FURNAS (1931), ANDEREGG (1931) e ANDREASSEN \& ANDERSEN (1930) como clássicos, sendo o de FURNAS (1931) mais defendido pelos pesquisadores, apesar de ser mais difícil e incômodo para ser utilizado. ANDREASSEN \& ANDERSEN (1930) propôs um modelo que é simples de se aplicar, no entanto, sua natureza é semi-empírica. Esse modelo apresenta a vantagem de não requerer nenhum fator de forma das partículas, mas é necessário que elas apresentem formas similares. Alguns pesquisadores não são favoráveis ao modelo de ANDREASSEN \& ANDERSEN, pois ele admite partículas infinitamente pequenas, o que é irreal. A fim de superar esse problema, DINGER \& FUNK (1992) combinaram a distribuição de ANDREASSEN \& ANDERSEN e FURNAS, criando a distribuição chamada de "Andreassen Modificado", na qual o tamanho da menor partícula foi incorporado.

A equação 3.1 é proposta por ANDREASSEN \& ANDERSEN, e a equação 3.2 foi sugerida por DINGER \& FUNK (Andreassen Modificado).

$$
\begin{aligned}
& \text { CPFT }=\left(\frac{d}{D}\right)^{q} \cdot 100 \\
& \text { CPFT }=\left[\frac{\left(d^{q}-d_{m}^{q}\right)}{\left(D^{q}-d_{m}^{q}\right)}\right] \cdot 100
\end{aligned}
$$

onde : $\quad C P F T=$ percentual acumulado de finos menor que "d" em volume;

$\mathrm{d}=$ tamanho da partícula;

$\mathrm{d}_{\mathrm{m}}=$ menor tamanho de partícula da distribuição;

$\mathrm{D}$ = maior tamanho de partícula da distribuição;

$q=$ coeficiente de distribuição.

Utilizando simulações computacionais, DINGER \& FUNK (1993) mostraram a influência do coeficiente " $q$ " no empacotamento. Eles concluíram que, se o valor " $q$ " for 0,37 ou menor, então $100 \%$ de empacotamento seria possível para uma distribuição infinita, enquanto que para o valor de " $q$ " acima de 0,37, existe sempre porosidade. Alguns pesquisadores, considerando as equações de ANDREASSEN \& ANDERSEN, indicam que para atingir melhor fluidez o valor " $q$ " não deve exceder aproximadamente 0,3 . Logo, usando-se valores de " $q$ " próximos de 0,3 tem-se uma mistura que 
necessita de vibração para melhorar seu adensamento, entretanto para valores de "q" menores que 0,25 a mistura torna-se auto-adensável. O efeito de reduzir o valor de " $q$ " é um aumento na quantidade de finos que influencia na interação entre as partículas, formando um líquido viscoso quando misturado com água.

\section{2- Materiais Utilizados e suas Propriedades}

Para a dosagem foram adotados materiais encontrados na região de São Carlos/SP com exceção da fibra de aço que é importada pela Belgo Bekaert Arames S.A.

\subsection{1- Areia}

Inicialmente dois tipos de areia foram adotadas, uma areia muito fina, denominada $A R E I A$ \ encontrada na região de São Carlos - SP, que é utilizada normalmente para acabamento na construção civil. A outra, denominada $A R E I A I$, foi fornecida pela Mineração Jundu, e sua extração é feita na região de Descalvado - SP (próximo a São Carlos).

A AREIA l é do tipo quartozita com grãos esféricos. A análise granulométrica foi feita segundo a NBR 7217:1987 no Laboratório de Estruturas - EESC - USP, e os resultados são mostrados na tabela 3.1. Segundo a NBR 7211:1983, a AREIA / foi classificada como muito fina, a massa unitária segundo a NBR 7251:1982 ficou em $1,43 \mathrm{~kg} / \mathrm{dm}^{3}$, e a massa específica, segundo a NBR $9776: 1987$, de $2,61 \mathrm{~kg} / \mathrm{dm}^{3}$.

\begin{tabular}{|c|c|c|}
\hline $\begin{array}{l}\text { Peneira } \\
\#(\mathbf{m m})\end{array}$ & \% Retida & $\begin{array}{c}\% \text { Retida } \\
\text { Acumulada }\end{array}$ \\
\hline 2,000 & 0,15 & 0,15 \\
\hline 1,190 & 0,22 & 0,37 \\
\hline 0,590 & 1,36 & 1,73 \\
\hline 0,420 & 8,20 & 9,93 \\
\hline 0,297 & 28,76 & 38,69 \\
\hline 0,149 & 48,99 & 87,68 \\
\hline 0,074 & 11,42 & 99,11 \\
\hline Fundo & 0,89 & 100,00 \\
\hline
\end{tabular}

A AREIA // é fornecida pela Mineração Jundu. A empresa forneceu boletim técnico com análise granulométrica e química que estão nas tabelas 3.2 e 3.3 . $\mathrm{O}$ diâmetro médio dos grãos da $A R E I A$ /l é $0,28 \mathrm{~mm}$ e a porcentagem de quartzo $\left(\mathrm{SiO}_{2}\right)$ é de $99,42 \%$ como mostrado na tabela 3.3, sendo assim, caracterizada como uma areia quartozita. Segundo a NBR 7211:1983 esta areia foi classificada como muito fina, a 
massa unitária segundo a NBR 7251:1982 ficou em 1,45kg/dm ${ }^{3}$, e a massa específica, segundo a NBR 9776:1987, de $2,64 \mathrm{~kg} / \mathrm{dm}^{3}$.

Tabela 3.2- Análise granulométrica da AREIA II

\begin{tabular}{c|c|c}
$\begin{array}{l}\text { Peneira } \\
\#(\mathbf{m m})\end{array}$ & \% Retida & $\begin{array}{l}\text { \% Retida } \\
\text { Acumulada }\end{array}$ \\
\hline 0,850 & 0,0 & 0,0 \\
\hline 0,600 & 0,4 & 0,4 \\
\hline 0,425 & 7,5 & 7,9 \\
\hline 0,300 & 29,1 & 37,0 \\
\hline 0,212 & 35,5 & 72,5 \\
\hline 0,150 & 20,4 & 92,9 \\
\hline 0,106 & 6,6 & 99,5 \\
\hline 0,075 & 0,4 & 99,9 \\
\hline 0,053 & 0,1 & 100,0 \\
\hline Fundo & 0,0 & 100,0 \\
\hline Diâmetro máx. caract.: $\phi_{\text {máx }}=0,6 \mathrm{~mm}$ \\
Módulo de Finura: MF = 1,303 \\
Classificação: Areia Muito Fina (Zona 1) \\
Fonte: Mineração Jundu
\end{tabular}

Tabela 3.3- Análise química da AREIA II

\begin{tabular}{|c|c|c|c|c|c|c|c|}
\hline$\% \mathrm{Fe}_{2} \mathrm{O}_{3}$ & $\% \mathrm{Al}_{2} \mathrm{O}_{3}$ & $\% \mathrm{TiO}_{2}$ & $\% \mathrm{MnO}_{2}$ & $\% \mathrm{ZrO}_{2}$ & \%P.F. & $\% \mathrm{SiO}_{2}$ & pH \\
\hline 0,25 & 0,12 & 0,055 & 0,001 & 0,013 & 0,14 & 99,42 & 6,7 \\
\hline
\end{tabular}

\subsection{2- Cimento}

Foram utilizados dois tipos de cimento Portland de alta resistência inicial, o CPV ARI PLUS e o CPV ARI RS, ambos fabricados pela empresa CIMINAS S.A. do grupo Holdercim. O cimento tipo PLUS é o CPV ARI comum, e o tipo RS é resistente a sulfato, contendo em sua composição escória de alto forno. A empresa forneceu as propriedades físicas e químicas destes cimentos, mostradas nas tabelas 3.4 a 3.8.

Tabela 3.4- Propriedades químicas dos cimentos

\begin{tabular}{l|c|c}
\hline \multirow{2}{*}{ Compostos } & \multicolumn{2}{|c}{ Tipos de Cimento } \\
\cline { 2 - 3 } & CP V ARI RS & CP V ARI PLUS \\
\hline P.F. & 2,41 & 2,37 \\
\hline $\mathrm{SiO}_{2}$ & 23,86 & 19,26 \\
\hline $\mathrm{Al}_{2} \mathrm{O}_{3}$ & 6,43 & 5,18 \\
\hline $\mathrm{Fe}_{2} \mathrm{O}_{3}$ & 2,99 & 3,17 \\
\hline $\mathrm{CaO}$ & 56,56 & 64,59 \\
\hline $\mathrm{MgO}$ & 2,41 & 0,64 \\
\hline $\mathrm{SO}_{3}$ & 2,89 & 2,62 \\
\hline $\mathrm{K}_{2} \mathrm{O}$ & 0,73 & 0,66 \\
\hline $\mathrm{Na}_{2} \mathrm{O}$ & 0,05 & 0,02 \\
\hline $\mathrm{Na}_{2} \mathrm{O}_{\text {equiv. }}$ & 0,53 & 0,45 \\
\hline $\mathrm{CaO}_{\text {livre }}$ & 0,92 & 0,99 \\
\hline $\mathrm{CO}_{2}$ & 2,15 & 2,21 \\
\hline $\mathrm{RI}_{\mathrm{FOn}}$ & 0,64 & 0,45 \\
\hline
\end{tabular}

Fonte: Holdercim S.A. 
Tabela 3.5- Composição potencial dos cimentos

\begin{tabular}{c|c|c|c}
\hline \multicolumn{2}{c|}{$\begin{array}{c}\text { Composição Potencial } \\
\text { Faixas aproximadas } \\
\text { (Metha \& Monteiro, 1994) }\end{array}$} & $\begin{array}{c}\text { CP V ARI RS } \\
\%\end{array}$ & $\begin{array}{c}\text { CP V ARI PLUS } \\
\%\end{array}$ \\
\hline $35 \%$ a 65\% & $\mathrm{C}_{3} \mathrm{~S}$ & 38,26 & 58,95 \\
\hline $10 \%$ a $40 \%$ & $\mathrm{C}_{2} \mathrm{~S}$ & 7,66 & 10,15 \\
\hline $0 \%$ a $15 \%$ & $\mathrm{C}_{3} \mathrm{~A}$ & 4,92 & 7,36 \\
\hline $5 \%$ a $15 \%$ & $\mathrm{C}_{4} \mathrm{AF}$ & 6,32 & 9,46 \\
\hline
\end{tabular}

Fonte: Holdercim S.A.

Tabela 3.6- Propriedades dos cimentos

\begin{tabular}{|c|c|c|c|c|}
\hline \multicolumn{2}{|c|}{ Características e Propriedades } & Unidade & CP V ARI RS & CP V ARI PLUS \\
\hline \multicolumn{2}{|c|}{ Massa Específica (NBR 6474)* } & $\mathrm{kg} / \mathrm{dm}^{3}$ & 3,08 & 3,12 \\
\hline \multicolumn{2}{|c|}{ Massa Unitária no Estado Solto (NBR 7251:1982)* } & $\mathrm{kg} / \mathrm{dm}^{3}$ & 1,01 & 1,02 \\
\hline \multirow[t]{3}{*}{ Finura: } & Resíduo \#200 (NBR 11579:1991) & $\%$ & 0,7 & 0,15 \\
\hline & Resíduo \#325 & $\%$ & 7,7 & 2,55 \\
\hline & Sup. Esp. Blaine (NBR7114:1998) & $\mathrm{cm}^{2} / \mathrm{g}$ & 3581 & 4600 \\
\hline \multirow[t]{2}{*}{ Tempo de Pega*: } & Início (NBR 11581:2002) & $\min$ & 137 & 135 \\
\hline & Fim (NBR11581:2002) & $\min$ & 277 & 200 \\
\hline \multirow{4}{*}{$\begin{array}{l}\text { Resistência à } \\
\text { Compressão }\left(\mathrm{f}_{\mathrm{cj}}\right) \\
\text { NBR7215:1996 }\end{array}$} & 1 dia & $\mathrm{MPa}$ & 20,8 & 28,8 \\
\hline & 3 dias & $\mathrm{MPa}$ & 34,0 & 43,1 \\
\hline & 7 dias & $\mathrm{MPa}$ & 40,4 & 47,9 \\
\hline & 28 dias & $\mathrm{MPa}$ & 49,7 & 57,3 \\
\hline
\end{tabular}

Fonte: Holdercim S.A. $\quad$ * Valores experimentais obtidos no LMABC (EESC-USP)

Tabela 3.7- Composição dos cimentos

\begin{tabular}{l|c|c}
\multicolumn{1}{c|}{ Compostos } & $\begin{array}{c}\text { CP V ARI RS } \\
\mathbf{\%}\end{array}$ & $\begin{array}{c}\text { CP V ARI PLUS } \\
\text { \% }\end{array}$ \\
\hline Clínquer & 60,40 & 90,33 \\
\hline Escória & 29,61 & -- \\
\hline Sulfato de Cálcio $=\mathrm{SO}_{3} \times 1,7$ & 4,91 & 4,45 \\
\hline Fíler Calcário $=2,27 \times \mathrm{CO} 2 / 0,96($ pureza $=96 \%)$ & 5,08 & 5,22 \\
\hline
\end{tabular}

Fonte: Holdercim S.A.

Tabela 3.8- Análise granulométrica do cimento CP V ARI- RS

\begin{tabular}{c|c}
\hline Abertura $(\boldsymbol{\mu m})$ & \% Retida \\
\hline 0,50 & 0,45 \\
\hline 1,32 & 1,99 \\
\hline 1,60 & 3,25 \\
\hline 1,95 & 3,90 \\
\hline 2,38 & 4,13 \\
\hline 2,90 & 4,22 \\
\hline 3,53 & 4,49 \\
\hline 4,30 & 5,19 \\
\hline 5,24 & 6,41 \\
\hline 6,39 & 8,01 \\
\hline 7,78 & 9,68 \\
\hline 9,48 & 11,28 \\
\hline 11,55 & 12,22 \\
\hline 14,08 & 11,43 \\
\hline 17,15 & 8,26 \\
\hline 20,90 & 3,93 \\
\hline 25,46 & 1,04 \\
\hline 31,01 & 0,12 \\
\hline 37,79 & 0,00 \\
\hline Fonte: Holdercim SA A
\end{tabular}

Fonte: Holdercim S.A 


\subsection{3- Aditivo superplastificante}

Foram utilizados dois tipos de superplastificante considerados de última geração. O primeiro é comercialmente conhecido como Conplast SP600 fabricado pela empresa Fosroc-Reax, sendo a massa específica de $1,08 \mathrm{~g} / \mathrm{cm}^{3}$ a $20^{\circ} \mathrm{C}$ e o teor de sólidos de $30 \%$ do volume. O segundo aditivo, conhecido comercialmente como Glenium 51, é fabricado pela empresa Master Builders Technologies - MBT. O manual do produto especifica que é um superplastificante de $3^{\circ}$ geração feito com base em uma cadeia de éter carboxílico modificado, ou policarboxilatos, é um líquido viscoso de cor marrom, isento de cloretos e atende às prescrições da norma ASTM C 494 (tipos A e F), ASTM C 1017, compatível com todos os cimentos que atendem a ASTM 150. Sua massa específica está entre $1,067 \mathrm{~g} / \mathrm{cm}^{3}$ e $1,107 \mathrm{~g} / \mathrm{cm}^{3}, \mathrm{pH}$ de 5 à 7 , viscosidade de 95 à $160 \mathrm{cps}$ a $20^{\circ} \mathrm{C}$, e teor de sólidos entre $28,5 \%$ a $31,5 \%$.

\subsection{4- Pó de quartzo}

O pó de quartzo utilizado também foi fornecido pela Mineração Jundu, que o comercializa com o nome Sílica Malha 325. A empresa forneceu boletim técnico com análises granulométrica e química mostradas nas tabelas 3.9 e 3.10.

Tabela 3.9- Análise granulométrica do pó de quartzo

\begin{tabular}{c|c|c|c}
\hline $\begin{array}{c}\text { Peneiras } \\
\text { ASTM E-11 }\end{array}$ & $\begin{array}{c}\text { Abertura } \\
(\mathbf{m m})\end{array}$ & \% Retida & $\begin{array}{c}\text { \% Retida } \\
\text { Acumulada }\end{array}$ \\
\hline 100 & 0,150 & 0,00 & 0,00 \\
\hline 140 & 0,106 & 0,06 & 0,06 \\
\hline 200 & 0,075 & 0,45 & 0,51 \\
\hline 325 & 0,045 & 7,00 & 7,51 \\
\hline$<325$ & $<0,045$ & 92,49 & 100,00 \\
\hline
\end{tabular}

Fonte: Mineração Jundu

Tabela 3.10- Análise química do pó de quartzo

\begin{tabular}{c|c|c|c|c}
\hline $\mathbf{\% F e}_{2} \mathbf{O}_{\mathbf{3}}$ & $\mathbf{\% \mathbf { A l } _ { 2 } \mathbf { O } _ { \mathbf { 3 } }}$ & $\mathbf{\%} \mathbf{T i O}_{\mathbf{2}}$ & $\mathbf{\% P . F}$. & $\mathbf{\%} \mathbf{S i O}_{\mathbf{2}}$ \\
\hline 0,025 & 0,057 & 0,02 & 0,11 & 99,73 \\
\hline \multicolumn{5}{l}{ Fonte: Mineração Jundu }
\end{tabular}

Como a análise granulométrica fornecida pela empresa não abrangia os grãos com diâmetros menores que $0,045 \mathrm{~mm}$, realizou-se ensaio de granulometria por raio laser com aparelho da marca "CILAS", cujo procedimento de ensaio foi o padrão para este equipamento. O ensaio foi realizado no Laboratório da empresa Faber-Castell, e o resultado mostrou que $90 \%$ dos grãos da amostra tinham diâmetro menores que $37,37 \mu \mathrm{m}$, 50\% possuíam diâmetro menores que 10,80 $\mu \mathrm{m}$, e 10\% apresentaram diâmetro menores que $1,33 \mu \mathrm{m}$, a distribuição granulométrica está mostrada na figura 3.1. 


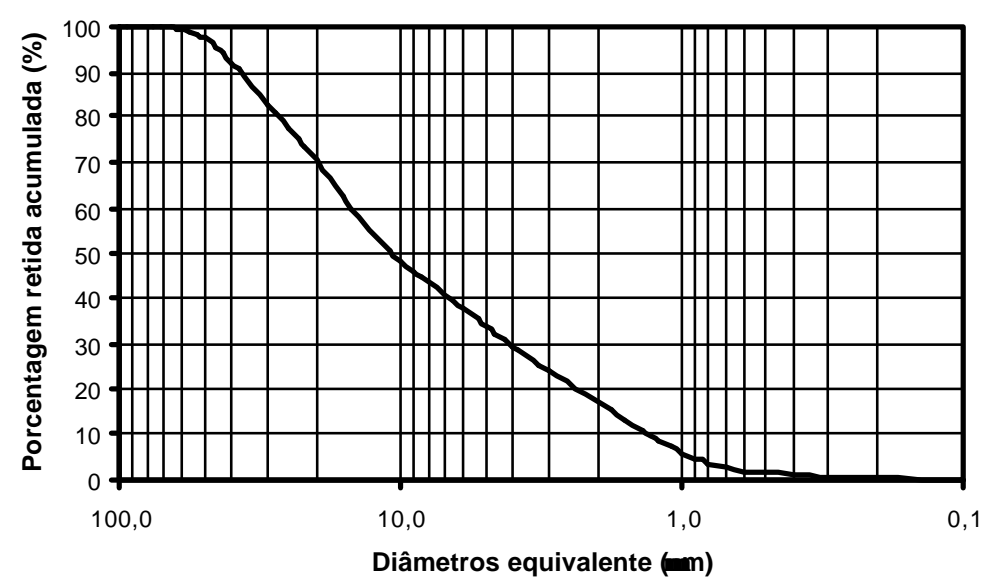

Figura 3.1- Distribuição Granulométrica do Pó de Quartzo

\subsection{5- Sílica ativa}

A sílica ativa (SA) utilizada foi a não densificada fornecida pela empresa Microsílica Tecnologia Indústria e Comércio Ltda., que indicou como massa específica do material o valor de $2222 \mathrm{~kg} / \mathrm{m}^{3}$, e superfície específica aproximadamente igual a $18.000 \mathrm{~cm}^{2} / \mathrm{g}$. A tabela 3.11 apresenta a análise química e a figura 3.2 a distribuição granulométrica da sílica ativa utilizada.

Tabela 3.11- Análise química da sílica ativa

\begin{tabular}{c|c}
\hline Composto & \% \\
\hline $\mathrm{PF}$ & 3,14 \\
\hline $\mathrm{SiO}_{2}$ & 94,30 \\
\hline $\mathrm{Al}_{2} \mathrm{O}_{3}$ & 0,09 \\
\hline $\mathrm{Fe}_{2} \mathrm{O}_{3}$ & 0,10 \\
\hline $\mathrm{CaO}$ & 0,30 \\
\hline $\mathrm{MgO}$ & 0,43 \\
\hline $\mathrm{SO}_{3}$ & -- \\
\hline $\mathrm{K}_{2} \mathrm{O}$ & 0,83 \\
\hline $\mathrm{Na}_{2} \mathrm{O}$ & 0,27 \\
\hline
\end{tabular}

Fonte: Microsílica Ltda.

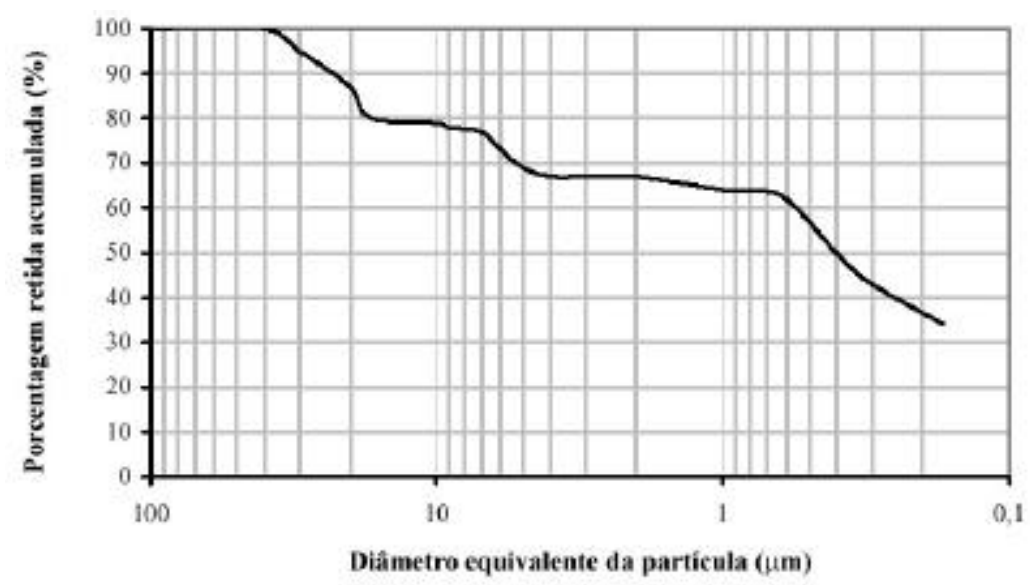

Figura 3.2- Distribuição granulométrica da sílica ativa Fonte: Microsílica Ltda. 


\subsection{6- Fibras metálicas}

As fibras metálicas utilizadas foram descritas no item 2.1.4, tinham comprimento de $13 \mathrm{~mm}$, diâmetro de $0,15 \mathrm{~mm}$ e formato reto. Fibras com essas condições não foram encontradas em fornecedores nacionais, no entanto, a empresa Belgo Bekaert Arames S.A. forneceu fibras com tais propriedades, figura 3.3. As fibras cedidas para a pesquisa são semelhantes àquelas utilizadas na construção da passarela no Canadá, descrita no item 1.5.1 do Capítulo 1, e também semelhantes æ̀s adotadas em pesquisas citadas nas publicações internacionais consultadas.
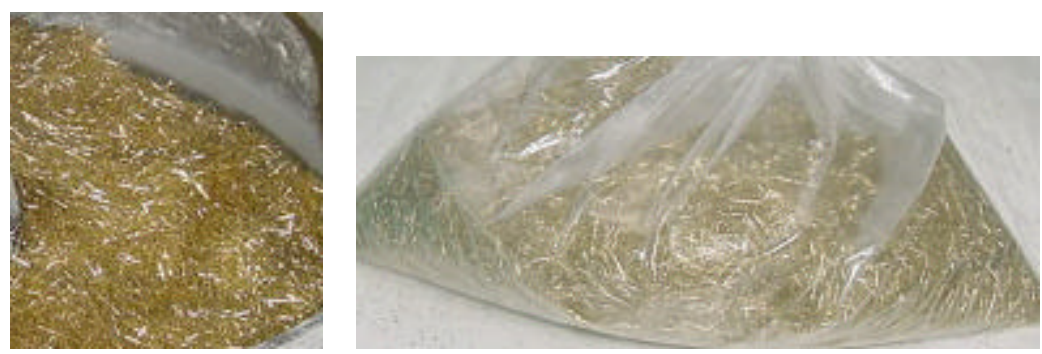

Figura 3.3- Fibras metálicas importadas

\section{3- Determinação da Composição dos Materiais}

\subsection{1- Dosagens preliminares}

Inicialmente foram feitos ensaios preliminares utilizando a dosagem indicada por AITCIN \& RICHARD (1996), que relatam a utilização do concreto de pós reativos na construção de uma passarela no Canadá, na dosagem indicada na tabela 3.12. Os ensaios serviram como primeiro contato na obtenção dos concretos de pós reativos, onde se pretendeu analisar as duas areias, os dois tipos de superplastificantes, e, também, as dificuldades que se teria para realizar a mistura dos materiais com os equipamentos do laboratório, assim como, analisar os procedimentos de moldagem para se obter um material bem adensado.

Tabela 3.12- Dosagem de AITCIN \& RICHARD (1996)

\begin{tabular}{l|c}
\hline \multicolumn{1}{c|}{ Material } & $\begin{array}{c}\text { Composição } \\
\left(\mathbf{k g} / \mathbf{m}^{\mathbf{3}} \mathbf{)}\right.\end{array}$ \\
\hline Cimento & 705 \\
\hline Areia & 1010 \\
\hline Sílica Ativa & 230 \\
\hline Pó de Quartzo & 210 \\
\hline Superplastificante & 19 \\
\hline Água & 195 \\
\hline
\end{tabular}

Para este estudo foram feitas 5 dosagens, tabela 3.13, onde se variou o tipo de areia (AREIA Ie AREIA II), o superplastificante (Conplast SP600 e Glenium51), o procedimento de mistura dos materiais, e o adensamento. Utilizou-se o misturador 
planetário de capacidade de 5 litros do Laboratório de Construção Civil - LCC, EESC USP, e foram moldados 8 corpos-de-prova cilíndricos de $5 \mathrm{~cm} \times 10 \mathrm{~cm}$ para cada mistura. As misturas 1, 2 e 5 foram ensaiadas nas idades de 3, 7, 14 e 28 dias, e as misturas 3 e 4 nas idades 7 e 14 dias.

Tabela 3.13- Ensaios preliminares

\begin{tabular}{c|c|c|c}
\hline Mistura & Areia & Aditivo & Relação a/c \\
\hline 1 & I & Conplast (3,7\%) & 0,40 \\
\hline 2 & II & Conplast (3,7\%) & 0,40 \\
\hline 3 & II & Conplast (2,0\%) & 0,30 \\
\hline 4 & II & Glenium51 (2,0\%) & 0,30 \\
\hline 5 & II & Glenium51 (2,0\%) & 0,30 \\
\hline
\end{tabular}

Na mistura 1 utilizou-se a AREIA I e o superplastificante Conplast SP600. O fator água/cimento inicial era de 0,20 e a porcentagem de superplastificante de 1,8\% da massa de cimento. O preparo aconteceu da seguinte maneira:

- colocou-se todo o material seco no misturador e se homogeneizou a mistura por aproximadamente 3 minutos;

- juntou-se o superplastificante com a água em uma solução única, em seguida, adicionou-se esta solução, em pequenas doses, na mistura seca;

- fazia-se a homogeneização da mistura úmida por aproximadamente 5 minutos.

A quantidade de água e superplastificante não foi suficiente para homogeneizar a mistura com o mínimo de trabalhabilidade, logo, decidiu-se adicionar à mesma quantidade de água e superplastificante à mistura, resultando em um fator água/cimento de 0,40 e porcentagem de $3,7 \%$ do superplastificante. O resultado foi uma pasta fluida e muito viscosa. Os corpos-de-prova foram moldados sem compactação e vibração. Depois de 24 horas os modelos foram desmoldados e colocados em câmara úmida por 7 dias. Na desmoldagem observaram-se vazios nos modelos alertando para maiores cuidados na moldagem. Os resultados dos ensaios à compressão axial estão na tabela 3.14.

A mistura 2 foi feita com a AREIA // e o superplastificante Conplast SP600. Utilizou-se a mesma dosagem e procedimentos da mistura 1, e foram observados defeitos nos modelos semelhantes aos encontrados na mistura 1.

Para a mistura 3, com a AREIA I/ e o superplastificante Conplast SP600, mudou-se o modo de preparo, adotando fator a/c de 0,25 e porcentagem de superplastificante de 2,0\%. Inicialmente misturou-se o cimento, a sílica ativa e o pó de quartzo por 5 minutos até que a mistura ficasse bem homogênea. Depois adicionaramse a água e o superplastificante em uma única solução com o misturador ligado por 
mais 2 minutos. Por último, colocou-se a areia. A mistura não alcançou boa trabalhabilidade, sendo necessário adicionar um pouco mais de água, atingindo um fator a/c de 0,30. Os corpos-de-prova foram moldados em mesa vibratória e a desmoldagem e cura ocorreram de acordo como o descrito para a mistura 1. Mesmo utilizando mesa vibratória para o adensamento, os modelos apresentaram alguns defeitos de moldagem.

A mistura 4 foi semelhante à mistura 3 , a diferença ocorreu no superplastificante utilizado, que foi o Glenium51. Manteve-se fator a/c de 0,30 e porcentagem de superplastificante de 2,0\%. Esta mistura apresentou melhor trabalhabilidade e os modelos não apresentaram defeitos de moldagem.

A mistura 5 foi a última a ser realizada nesses ensaios preliminares, que teve as mesmas quantidades da mistura 4, sendo que a moldagem foi feita com adensamento manual, onde os corpos-de-prova foram preenchidos em três camadas adensadas com um soquete metálico. A mistura apresentou mais uma vez boa trabalhabilidade e os modelos não apresentaram nenhum defeito.

Os resultados dos ensaios à compressão axial relativos as misturas preliminares são apresentados na tabela 3.14.

Tabela 3.14- Resistências médias à compressão axial dos ensaios preliminares

\begin{tabular}{c|c|c|c|c}
\hline \multirow{2}{*}{ Mistura } & \multicolumn{4}{|c}{ Resistência média (MPa) nas idades dos ensaios (dias) } \\
\cline { 2 - 5 } & $\mathbf{3}$ & $\mathbf{7}$ & $\mathbf{1 4}$ & $\mathbf{2 8}$ \\
\hline $\mathbf{1}$ & 58,39 & 80,07 & 39,99 & 64,96 \\
\hline $\mathbf{2}$ & 35,05 & 49,33 & 64,67 & 71,96 \\
\hline $\mathbf{3}$ & -- & 71,34 & 122,25 & -- \\
\hline $\mathbf{4}$ & -- & 88,30 & 113,00 & -- \\
\hline $\mathbf{5}$ & 61.44 & 76,82 & 110,87 & 127,50 \\
\hline
\end{tabular}

De acordo com os ensaios preliminares, o modo de preparo da mistura influenciou bastante na qualidade do concreto de pós reativos. As duas primeiras misturas que foram moldadas sem adensamento, apresentaram grandes defeitos que influenciaram na resistência à compressão. As misturas 3 e 4 apresentaram poucos defeitos superficiais, e aparentemente, não causaram grandes influencias na resistência à compressão. A mistura 5 foi a que menos apresentou defeitos superficiais.

Com relação ao tipo de areia, não foi detectada nenhuma diferença entre as areias I e // com relação a trabalhabilidade, quanto a resistência à compressão, a análise ficou comprometida por causa do grande desvio nos resultados provocados pelos defeitos de moldagem. No entanto, optou-se pela $A R E I A$ II, pois é uma areia industrializada e, com isto, pode-se garantir a mesma granulometria para os ensaios futuros. Com relação ao superplastificante, notou-se que o Glenium51 ofereceu melhor 
trabalhabilidade e maior tempo de atuação durante o preparo dos modelos, mas não influenciou na resistência àcompressão quando, comparado ao Conplast SP600.

\subsection{2- Dosagem pelo método do empacotamento [ANDREASSEN \& ANDERSEN]}

Esta pesquisa teve como princípio desenvolver uma dosagem para o concreto de pós reativos, considerando a teoria do empacotamento. A dosagem utilizada pelos canadenses para construir a passarela em Sherbrooke, item 1.5.1, serviu apenas como parâmetro para os primeiros ensaios, pois os materiais adotados nesta pesquisa possuem propriedades diferentes dos utilizados no Canadá, sendo necessário estudo de composição entre os materiais que foram utilizados, a fim de alcançar a maior densidade.

O estudo de dosagem utilizado foi feito tomando como referência o método proposto por ANDREASSEN \& ANDERSEN (1930), que apresenta um modelo matemático de natureza semi-empírica para promover o empacotamento das partículas dos materiais, este método está descrito no item 3.1.1.

Para utilização do modelo, precisou-se dividir os componentes do CPR em classes granulométricas como mostrado na tabela 3.15. Em seguida, variou-se o parâmetro "q" da equação para cada classe, a fim de obter o empacotamento das partículas com boa trabalhabilidade. Sabe-se que para valores de "q" menores que 0,25 a mistura se torna auto-adensável em virtude da maior quantidade de finos, e que para valores maiores que 0,37 a mistura não alcança o empacotamento perfeito, tornado-se mais porosa, então adotou-se os valores de "q" variando de 0,20 até 0,37 como mostra a tabela 3.15. Os valores adotados na variação do parâmetro "q" foram puramente intuitivos.

Tabela 3.15- Classes dos materiais utilizados e valores do parâmetro " $\mathrm{g}$ "

\begin{tabular}{c|c|c|c}
\hline Classe & Material & Intervalo dos diâmetros & Variação de " $\boldsymbol{q}$ " \\
\hline 1 & Areia & $0,59 \mathrm{~mm}-0,074 \mathrm{~mm}$ & $0,20-0,22-0,25-0,29$ \\
\hline 2 & Pó de Quartzo & $0,08 \mathrm{~mm}-0,01 \mathrm{~mm}$ & $0,25-0,28-0,30-0,32$ \\
\hline 3 & Cimento & $0,03 \mathrm{~mm}-0,0005 \mathrm{~mm}$ & $0,30-0,32-0,35-0,37$ \\
\hline 4 & Sílica Ativa & $<0,0005 \mathrm{~mm}$ & --- \\
\hline
\end{tabular}

Percebe-se que a granulometria do pó de quartzo e do cimento se sobrepõem, e que, de acordo com a granulometria do cimento, $37 \%$ dos seus grãos estão na faixa granulométrica entre $0,03 \mathrm{~mm}(30 \mu \mathrm{m})$ e $0,01 \mathrm{~mm}(10 \mu \mathrm{m})$. Logo, considerando que o volume de material calculado para a classe 2, 37\% seria cimento e $63 \%$ o pó de quartzo. Lembrando-se que a fórmula de Andreassen \& Andersen calcula a porcentagem acumulada de finos com diâmetro menor que a classe em questão. 
A quantidade de água foi dosada por tentativas até que a mistura atingisse boa trabalhabilidade. Para o superplastificante foi adotado a porcentagem de $2 \% \mathrm{em}$ relação ao volume de cimento.

Para a variação de "q" adotada na tabela 3.15, fez-se uma combinação que gerou 64 dosagens. Esse cálculo foi facilitado com desenvolvimento de um programa computacional, o qual fornecia a massa de cada material, inclusive a quantidade de água e superplastificante de acordo com os dados fornecidos.

Das 64 dosagens geradas pela combinação do parâmetro "q", escolheram-se duas para realizar os primeiros ensaios. Tais dosagens foram escolhidas por apresentarem o maior e o menor consumo de cimento. As dosagens em massa são apresentadas na tabela 3.16 .

Tabela 3.16- Composição das dosagens 1 e 2 (em massa)

\begin{tabular}{l|c|c}
\hline \multicolumn{1}{c|}{ Material } & Dosagem 1 & Dosagem 2 \\
\hline Cimento & 1 & 1 \\
\hline Areia & 0,614 & 1,101 \\
\hline Pó de Quartzo & 0,170 & 0,235 \\
\hline Sílica Ativa & 0,177 & 0,246 \\
\hline Superplastificante (2\%) & 0,02 & 0,02 \\
\hline Relação a/c & 0,216 & 0,216 \\
\hline
\end{tabular}

O procedimento de mistura para as duas dosagens foi:

- colocou-se todo o material seco em um saco plástico e fez-se a mistura manual até que ficasse visualmente homogênea;

- despejou-se o material em um misturador planetário de capacidade de 5 litros, que era ligado em baixa rotação;

- misturou-se a água com o superplastificante em uma única solução e foi adicionada àmistura aumentando-se a rotação do misturador.

Para determinar a quantidade de água, utilizou-se o seguinte procedimento: na dosagem 1, adotou-se inicialmente fator água/cimento de 0,20 misturada com todo superplastificante e aumentou-se a velocidade do misturador, esperou-se em torno de 2 minutos e, em seguida, adicionaram-se pequenas doses de água até que o material aparentasse boa trabalhabilidade, isso aconteceu com fator água/cimento de 0,216. $\mathrm{Na}$ mistura 2 agiu-se da mesma maneira, sendo que partiu-se inicialmente com fator água/cimento de 0,19 e adicionou-se água, alcançando o mesmo fator água/cimento de 0,216 . Vale ressaltar que a primeira dosagem apresentou melhor trabalhabilidade que a segunda. 
Após a mistura de cada dosagem, foram feitas as moldagens de seis corposde-prova cilíndricos, de dimensões $5 \mathrm{~cm} \times 10 \mathrm{~cm}$, e adensados manualmente com soquete. Os corpos-de-prova eram desformados com 24 horas e colocados em câmara úmida por 7 dias, em seguida, permaneciam em meio ambiente até a data dos ensaios. Três corpos-de-prova foram ensaiados aos 14 dias e os outros três com 28 dias. A média dos resultado dos ensaios àcompressão axial das dosagens 1 e 2 estão na tabela 3.17 .

Tabela 3.17- Resistências médias à compressão axial das dosagens 1 e 2

\begin{tabular}{c|c|c}
\hline \multirow{2}{*}{ Dosagem } & \multicolumn{2}{|c}{ Resistência média (MPa) nas idades dos ensaios (dias) } \\
\cline { 2 - 3 } & $\mathbf{1 4}$ & $\mathbf{2 8}$ \\
\hline $\mathbf{1}$ & 88,00 & 103,22 \\
\hline $\mathbf{2}$ & 89,76 & 128,85 \\
\hline
\end{tabular}

As dosagens preliminares, e as feitas utilizando o método do empacotamento, não apresentaram grandes diferenças quanto àresistência àcompressão. No entanto, as dosagens feitas pelo método do empacotamento apresentaram melhor trabalhabilidade e menor relação água/cimento.

Considerando a dosagem desenvolvida pelo método do empacotamento para obter concretos, a resistência à compressão alcançada, a trabalhabilidade atingida, o consumo de cimento, e o fator água/cimento, tomou-se como base a dosagem da tabela 3.18 para dar sequência aos estudos de dosagens e propriedades do concreto de pós reativos.

Tabela 3.18- Dosagem para concreto de pós reativos

\begin{tabular}{l|c|c}
\hline \multicolumn{1}{c|}{ Material } & Relação $($ em massa) & Consumo $\left(\mathbf{k g} / \mathbf{m}^{\mathbf{3}}\right)$ \\
\hline Cimento & 1 & 854 \\
\hline Areia & 1,101 & 939 \\
\hline Pó de Quartzo & 0,235 & 201 \\
\hline Sílica Ativa & 0,246 & 210 \\
\hline Superplastificante $(2 \%)$ & 0,020 & 17 \\
\hline Água & 0,216 & 184 \\
\hline
\end{tabular}

Apesar da quantidade de dosagens publicadas em trabalhos científicos, percebeu-se que na realidade existiam apenas duas dosagens diferentes, encontradas nos artigos RICHARD \& CHEYREZY (1995) e AITCIN \& RICHARD (1996). Verificouse também que a maioria das dosagens utilizadas nos trabalhos foram baseadas na publicação de AITCIN \& RICHARD (1996), entre os trabalhos que utilizaram esta dosagem, pode-se relacionar: BEHLOUL, BERNIER, CHEYREZY (1996); BONNEAU, LACHEMI, DALLAIRE, DUGAT, AITCIN (1997); BONNEAU, POULIN, DUGAT, RICHARD, AITCIN (1996); DALLAIRE, AITCIN, LACHEMI, (1998); DALLAIRE, BONNEAU, LACHEMI, AITCIN (1996). 
A dosagem desenvolvida nesta pesquisa, tabela 3.18, foi comparada com as publicadas em RICHARD \& CHEYREZY (1995) e AITCIN \& RICHARD (1996), como mostra a tabela 3.19. Conclui-se que a dosagem desenvolvida é diferente das outras duas utilizadas correntemente nos trabalhos analisados, no entanto, tem maior proximidade com a proposta por RICHARD \& CHEYREZY (1995). As diferenças entre as dosagens é esperada, em virtude da utilização de materiais com propriedades diferentes das utilizadas nas outras pesquisas.

Tabela 3.19- Comparação entre dosagens para concreto de pós reativos (em massa)

\begin{tabular}{l|c|c|c}
\hline \multicolumn{1}{c|}{ Material } & Desenvolvida & Richard \& Cheyrezy (1995) & Aitcin \& Richard (1996) \\
\hline Cimento & 1 & 1 & 1 \\
\hline Areia & 1,101 & 1,100 & 1,432 \\
\hline Pó de Quartzo & 0,235 & 0,390 & 0,298 \\
\hline Sílica Ativa & 0,246 & 0,230 & 0,326 \\
\hline Superplastificante & 0,020 & 0,019 & 0,027 \\
\hline Água & 0,216 & 0,170 & 0,280 \\
\hline
\end{tabular}

\section{4- Ensaios Acessórios para Determinação da Dosagem}

Depois de determinar a composição granulométrica adequada para os componentes do CPR, que correspondesse a um bom empacotamento das partículas e fornecesse uma resistência à compressão elevada, partiu-se para a análise de outras variáveis que poderiam influenciar nas propriedades mecânicas do CPR.

\subsection{1- Programa experimental para os ensaios acessórios}

As propriedades mecânicas do CPR são influenciadas por vários fatores. Neste trabalho se deteve ao estudo da influência das seguintes variáveis: tipo de cimento; temperatura da água de mistura; relação água/cimento; tipo de cura e sua temperatura; idade do concreto; tempo de cura úmida pré cura térmica; e da quantidade de fibras, o qual tiveram seus efeitos analisados separadamente.

O estudo experimental pretendeu analisar o comportamento da resistência à compressão do CPR variando-se os parâmetros pré-determinados.

A dosagem utilizada para os ensaios acessórios foi a obtida no estudo da composição granulométrica exposta no item 3.3.2, tabela 3.18, modificando-se apenas a relação água/cimento e a porcentagem de superplastificante, que foi de $3 \% \mathrm{em}$ relação ao cimento.

Para estudar a influência da relação água/cimento, adotaram-se três valores: $0,16,0,18$ e 0,20 , resultando em três dosagens como exposto na tabela 3.20. Neste estudo foram utilizadas cura úmida, a temperatura ambiente $\left( \pm 23^{\circ} \mathrm{C}\right)$, e cura térmica as temperaturas de $60^{\circ} \mathrm{C}, 80^{\circ} \mathrm{C}$ e $100^{\circ} \mathrm{C}$, totalizando 12 concretagens. Para cada 
concretagem foram moldados 12 corpos-de-prova e ensaiados em número de 3 nas idades de 3, 7, 14 e 28 dias, além de medir o índice de consistência de cada mistura, "flow table", segundo a NBR 7215:1982. O programa experimental para análise desses parâmetros é mostrado na tabela 3.21.

Tabela 3.20- Dosagem para os ensaios acessórios (relação em massa)

\begin{tabular}{l|c|c|c}
\multicolumn{1}{c|}{ Material } & Dosagem 1 & Dosagem 2 & Dosagem 3 \\
\hline Cimento & 1 & 1 & 1 \\
\hline Areia & 1,101 & 1,101 & 1,101 \\
\hline Pó de Quartzo & 0,235 & 0,235 & 0,235 \\
\hline Sílica Ativa & 0,246 & 0,246 & 0,246 \\
\hline Superplastificante (3\%) & 0,030 & 0,030 & 0,030 \\
\hline Água & 0,160 & 0,180 & 0,200 \\
\hline
\end{tabular}

Tabela 3.21- Programa experimental para os ensaios acessórios

\begin{tabular}{|c|c|c|c|c|}
\hline \multirow{2}{*}{$\begin{array}{c}\text { Relação } \\
\text { água/cimento }\end{array}$} & \multicolumn{4}{|c|}{ Temperatura $\left({ }^{\circ} \mathrm{C}\right)$} \\
\hline & $\# 23$ & 60 & 80 & 100 \\
\hline 0,16 & 12cp's & $12 \mathrm{cp}$ 's & $12 \mathrm{cp}$ 's & 12cp's \\
\hline 0,18 & 12cp's & $12 \mathrm{cp}$ 's & 12cp's & 12cp's \\
\hline 0,20 & 12cp's & $12 \mathrm{cp}$ 's & $12 \mathrm{cp}$ 's & 12cp's \\
\hline
\end{tabular}

Os modelos submetidos à cura úmida foram moldados e colocados no ambiente do laboratório por 24 horas, em seguida levados para câmara úmida, onde permaneceram até as datas programadas para os ensaios. As séries submetidas a cura térmica, após 24 horas de cura ao ar, eram imersa em água e aquecidas gradualmente até a temperatura programada para a respectiva série.

O tempo de cura térmica total (aquecimento, temperatura estável e resfriamento) correspondia a 16 horas, em seguida os corpos-de-prova seguiam para câmara úmida onde permaneciam até a data do ensaio.

Todos os corpos-de-prova tinham as faces superior e inferior planificadas, por retífica mecânica, para evitar concentração de tensões durante a aplicação da força pela máquina de ensaio.

Com a execução destes ensaios, pode-se analisar a influência de cada parâmetro no comportamento da resistência àcompressão, tendo assim uma idéia das interferências que estes podem causar, ajudando na determinação da dosagem final.

\subsection{2- Influência da relação água/cimento}

De acordo com a Lei de Abrams, "quanto maior a quantidade de água na mistura, menor a resistência àcompressão do concreto". Esta lei é válida para relação água/cimento acima do mínimo necessário para hidratação de todo cimento da mistura, bem como para concreto de resistência usual e com pouca quantidade de finos na sua composição. 
Os concretos de pós reativos não se enquadram nesta lei, pois contém quantidade de água extremamente baixa, além de volume de finos exagerado, comparados com os concretos usuais.

Os ensaios realizados consistiam em analisar as três dosagens da tabela 3.20 , curadas a quatro temperaturas, como exposto na tabela 3.21, a fim de conhecer o comportamento da resistência à compressão, quando variava-se: a quantidade de água na mistura, a temperatura de cura, e a idade do concreto. Os resultados dos ensaios são mostrados nas figuras 3.4, 3.5, 3.6 e 3.7 .

Percebeu-se que para as três relações água/cimente adotadas - 0,16, 0,18 e 0,20 - não foi notado grande variação na resistência à compressão, principalmente para baixas temperaturas de cura. No entanto, observou-se uma tendência de aumento da resistência àcompressão com o aumento da relação água/cimento.

Esse comportamento é contrário a Lei de Abrams, conforme já exposto anteriormente, podendo ser atribuído à falta de hidratação de todas as partículas de cimento. Aumentando-se a quantidade de água, aumenta-se a quantidade de cimento hidratado, possibilitando também obter um concreto com maior trabalhabilidade, figura 3.8, diminuindo assim a quantidade de ar incorporado bem como os defeitos de moldagem dos corpos-de-prova, resultando em um possível aumento na resistência à compressão.

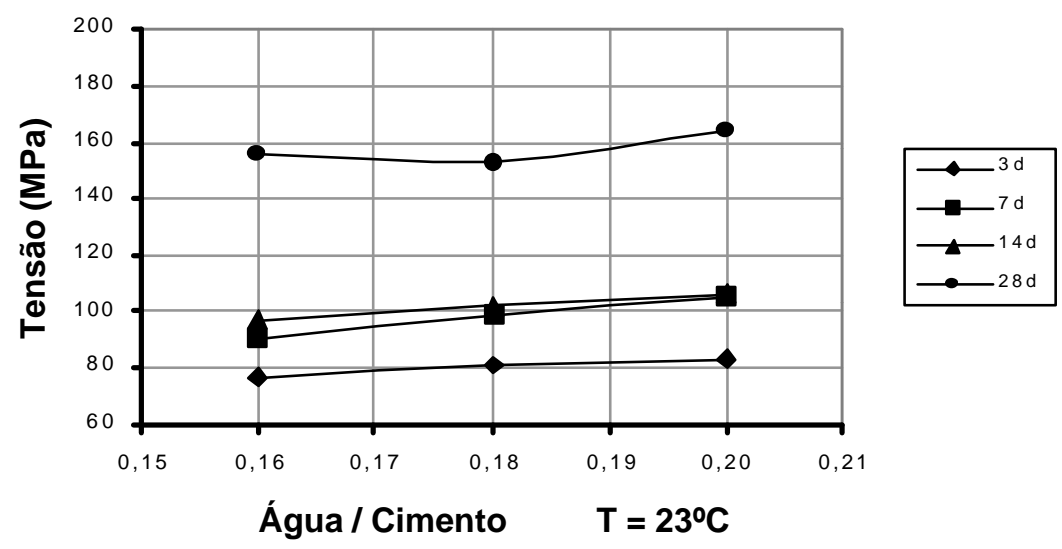

Figura 3.4 - Resistência à compressão em função da relação água/cimento. Cura à temperatua ambiente. 


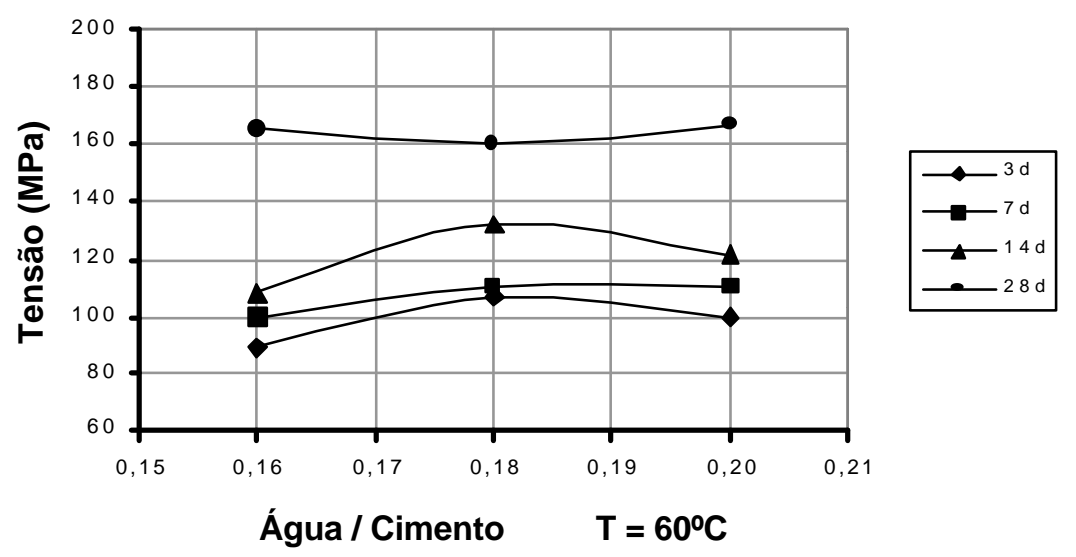

Figura 3.5 - Resistência à compressão em função da relação água/cimento. Cura térmica a $60^{\circ} \mathrm{C}$.

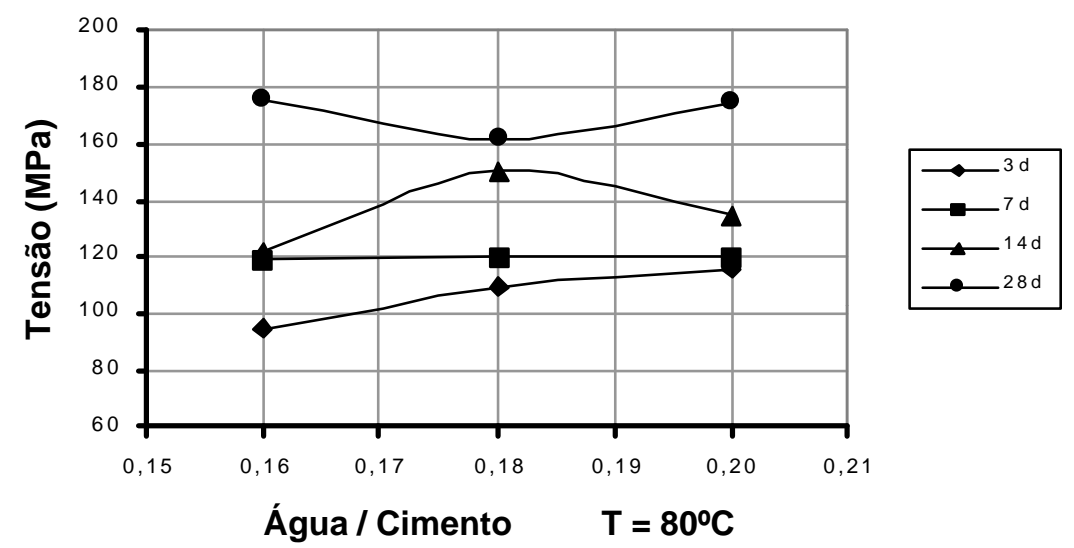

Figura 3.6 - Resistência à compressão em função da relação água/cimento. Cura térmica a $80^{\circ} \mathrm{C}$.

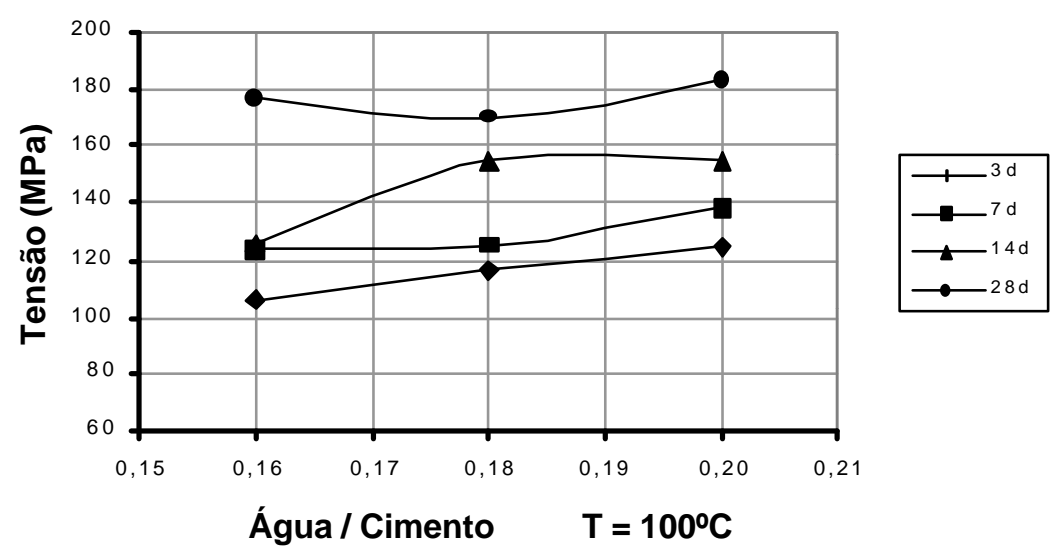

Figura 3.7 - Resistência à compressão em função da relação água/cimento. Cura térmica a $100^{\circ} \mathrm{C}$.

Para cada dosagem realizada nos ensaios acima, mediu-se o índice de consistência da mistura (flow table), segundo a NBR 7215:1982. Percebeu-se que a fluidez desse concreto aumenta quando se adiciona maior quantidade de água na mistura, porém esse comportamento apresenta-se de forma não linear, como mostrada na figura 3.8 . 


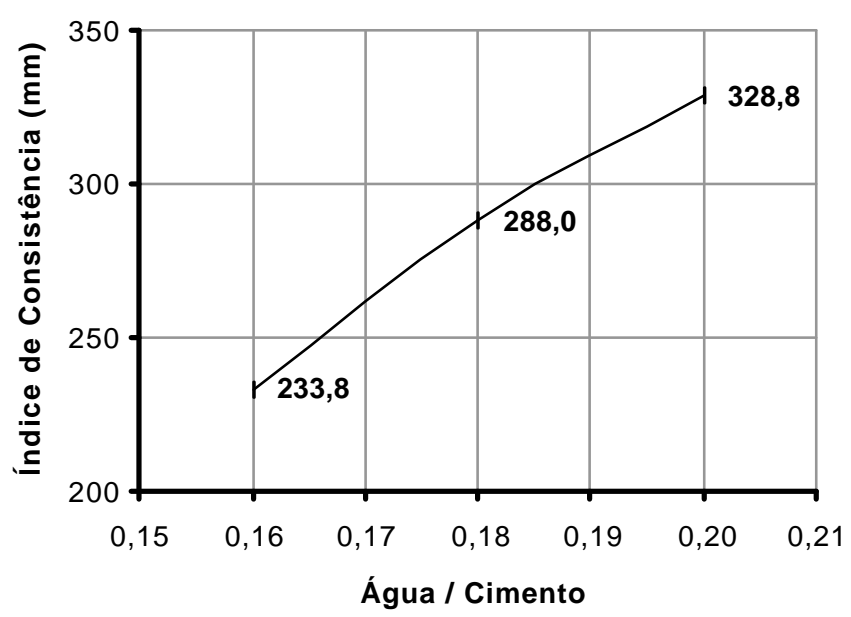

Figura 3.8 - Índice de consistência em função da relação água/cimento.

Com esses ensaios, notou-se que independente da temperatura de cura ou da idade do concreto, o aumento da relação água/cimento provocou tendência de crescimento da resistência à compressão, e esse crescimento ocorreu de modo não linear, onde provavelmente existe um valor para a relação água/cimento, a partir da qual a resistência àcompressão apresenta tendência de queda.

Considerando os dados dos ensaios de resistência à compressão e trabalhabilidade, adotou-se a relação água/cimento de 0,18 como parâmetro fixo para os estudos das propriedades mecânicas do concreto de pós reativos.

\subsection{3- Influência da temperatura de cura}

Foram analisados dois tipos de cura para o concreto desenvolvido: cura úmida e cura térmica. As dosagens adotadas para este estudo foram a da tabela 3.20, e as temperaturas definidas para realizar a cura do concreto foram: temperatura ambiente $\left( \pm 23^{\circ} \mathrm{C}\right), 60^{\circ} \mathrm{C}, 80^{\circ} \mathrm{C}$ e $100^{\circ} \mathrm{C}$. O programa experimental proposto foi o da tabela 3.21 , onde para cada temperatura de cura moldaram-se três série de 12 corpos-de-prova cada, com diferentes relações água/cimento.

Os modelos submetidos a cura a temperatura ambiente eram levados para câmara úmida após 24 horas de moldados. Para as séries submetidas a cura térmica, os corpos-de-prova eram moldados e após 24 horas imersos em água, a qual era aquecida gradualmente até a temperatura preestabelecida, onde permanecia por 12 horas, em seguida resfriados até a temperatura ambiente. Todo o ciclo de cura térmica durava em torno de 16 horas.

Os resultados desses ensaios mostraram que a resistência à compressão aumentava significativamente conforme a temperatura de cura térmica era aumentada, 
como mostram as figuras 3.9, 3.10, 3.11 e 3.12. Este comportamento era registrado independente da relação água/cimento e da idade do concreto.

Percebeu-se também que este efeito era reduzido em corpos-de-prova de idades elevadas, indicando que o aumento da temperatura de cura acelerava o crescimento da resistência à compressão nas primeiras idades, podendo não ter grande influência para idades superiores aos 28 dias.

O aumento da temperatura de cura gerou também crescimento mais acentuado da resistência à compressão em concretos com maiores quantidades de água de amassamento. Isto provavelmente ocorreu em virtude da maior quantidade de partículas de cimento hidratadas.

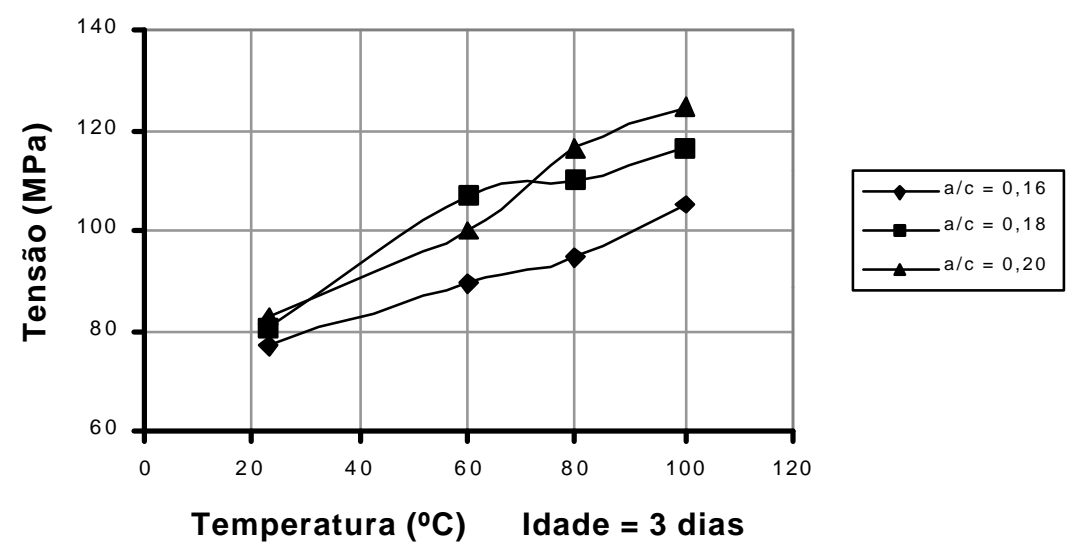

Figura 3.9 - Resistência à compressão em função da temperatura de cura térmica. Idade de 3 dias.

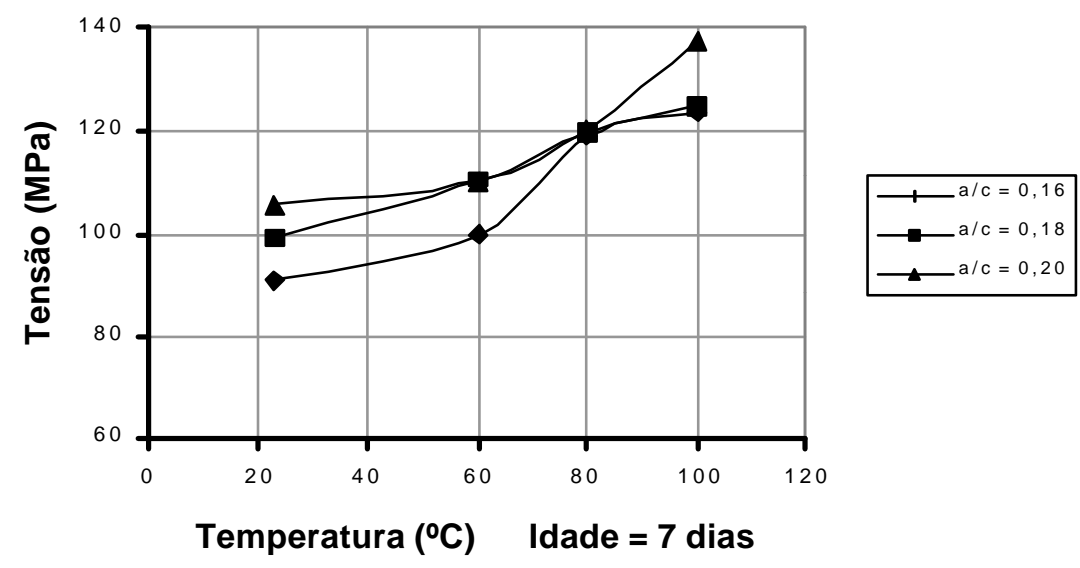

Figura 3.10 - Resistência à compressão em função da temperatura de cura térmica. Idade de 7 dias. 


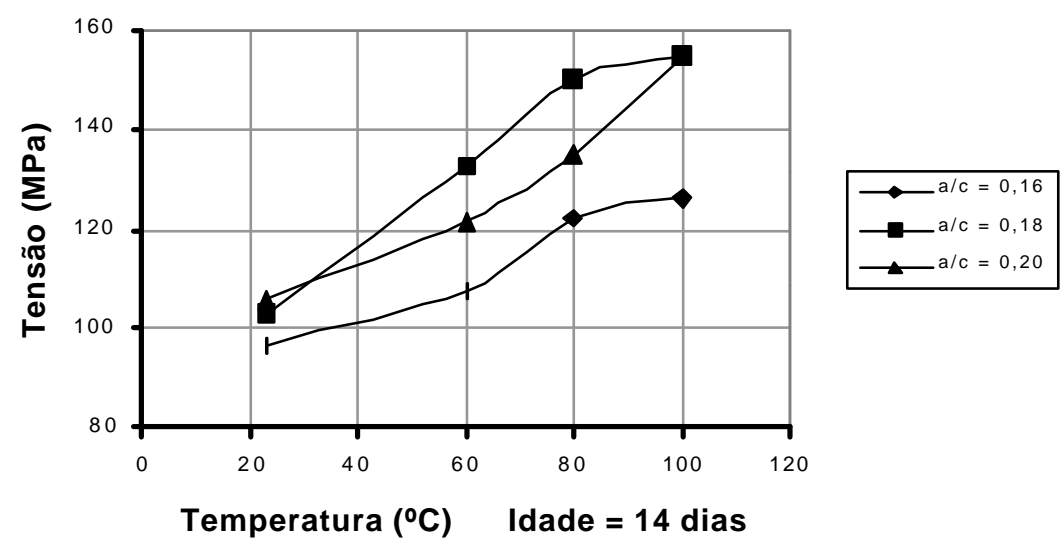

Figura 3.11 - Resistência à compressão em função da temperatura de cura térmica. Idade de 14 dias.

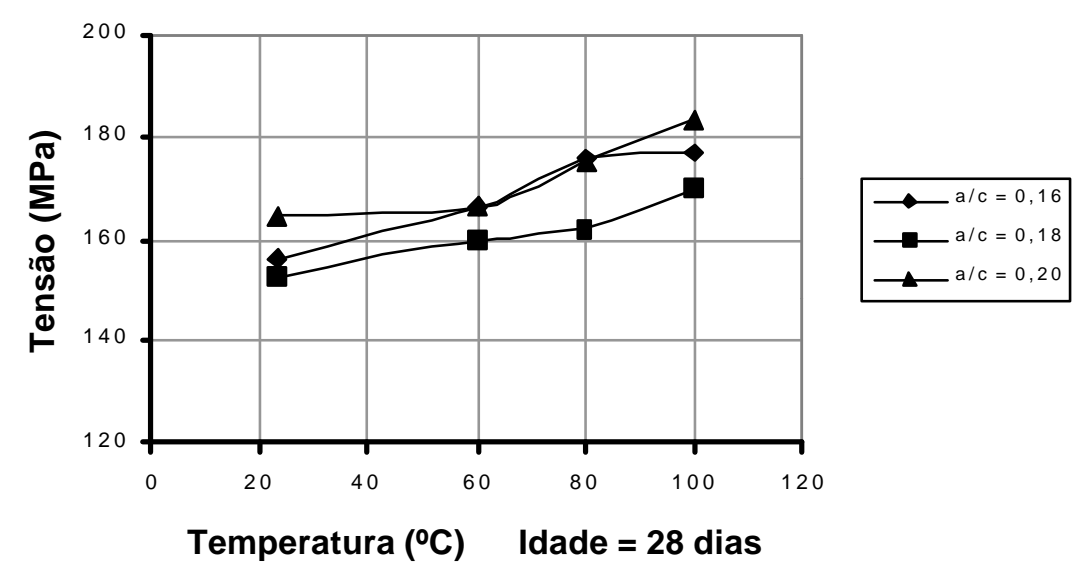

Figura 3.12 - Resistência à compressão em função da temperatura de cura térmica. Idade de 28 dias.

Analisando os ensaios, pode-se concluir que a temperatura ideal para a cura do concreto de pós reativos não pode ser definida apenas com os resultados obtidos, pois provavelmente temperaturas acima de $100^{\circ} \mathrm{C}$ levaria a resistências àcompressão maiores. No entanto, os equipamentos disponíveis no laboratório não permitem temperaturas acima de $100^{\circ} \mathrm{C}$, o que limitou o estudo.

Logo, considerando os resultados dos ensaios e os equipamentos disponíveis, percebeu-se que os concretos com maiores idades apresentaram menor influência da temperatura de cura. Assim, adotou-se a temperatura de $80^{\circ} \mathrm{C}$ para cura térmica nos estudos das propriedades mecânicas do concreto de pós reativos.

\subsection{4- Influência da idade}

A resistência à compressão do concreto sob condições normais cresce com o passar do tempo, isto ocorre por causa da hidratação das partículas de cimento que, apesar do processo ser lento, é constante durante toda a vida do material. 
A análise experimental realizada constatou que o concreto de pós reativos também tem a resistência à compressão aumentada com o tempo, resultado esperado pois o aglomerante utilizado é o cimento Portland. As figuras 3.13, 3.14 e 3.15 mostram o crescimento dessa resistência dos 3 até os 28 dias de idade para os diferentes tipos de cura e relação água/cimento.

Percebe-se que aos 3 dias de idade o concreto submetido a cura úmida atinge em média cerca de $51 \%$ da resistência à compressão alcançada aos 28 dias, e para os concretos submetidos a cura térmica, a resistência aos 3 dias chega a ser de $63 \%$, evidenciando o efeito da temperatura de cura nas primeiras idades. Logo, a cura térmica tem maior influência na resistência de concreto com pouca idade, sendo esse efeito minimizado para as idades maiores, como pode ser observado nas figuras abaixo.

Pode-se dizer então que o concreto de pós reativos apresenta propriedade de elevada resistência à compressão nas primeiras idades, alcançando intensidades de 100MPa sem adição de fibras. Aos 28 dias essa resistência pode atingir 180MPa, mesmo sem a aplicação de cura térmica.

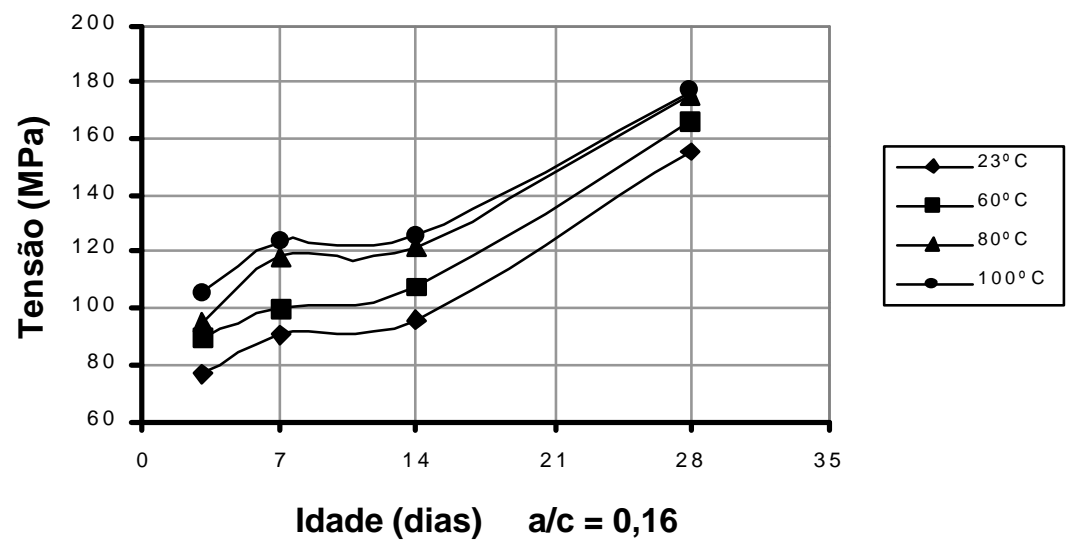

Figura 3.13 - Resistência à compressão em função da idade. Relação água/cimento de 0,16.

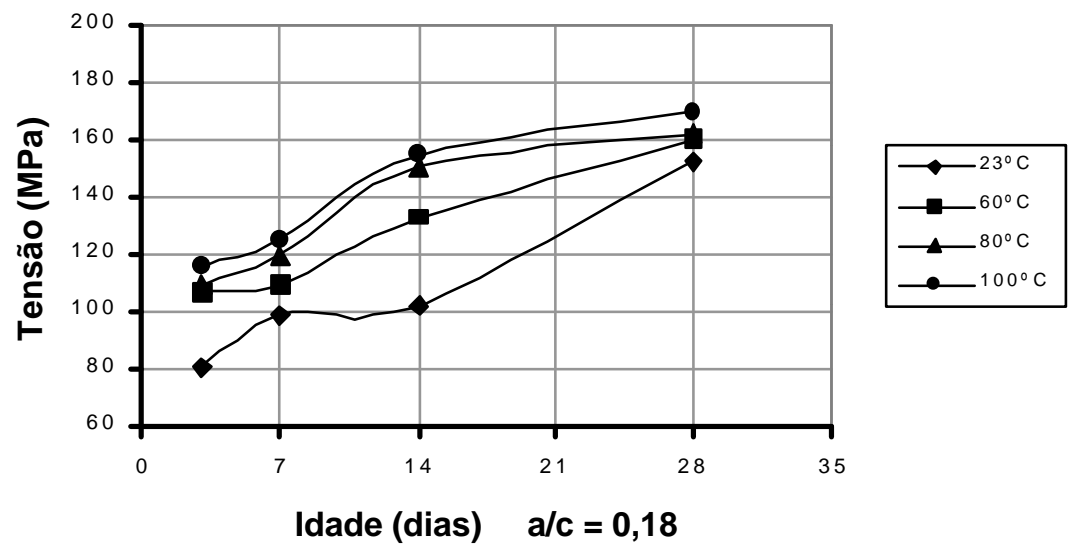

Figura 3.14 - Resistência à compressão em função da idade. Relação água/cimento de 0,18. 


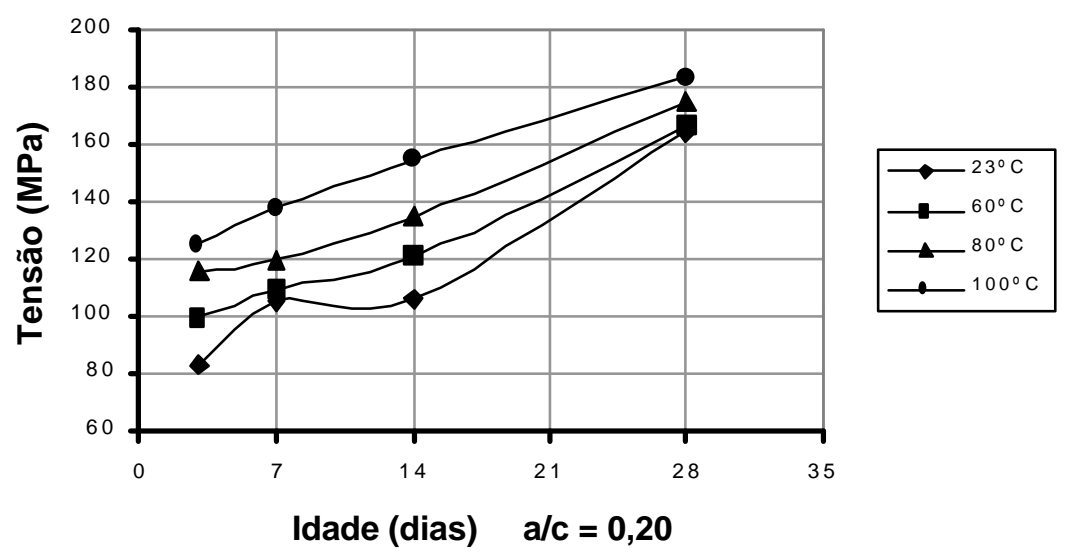

Figura 3.15 - Resistência à compressão em função da idade. Relação água/cimento de 0,20 .

Os resultados dos ensaios mostraram que se alcançaram maiores resistências com concretos na idade de 28 dias, e que nesta idade a influência da temperatura de cura era menor, com isso, adotou-se como parâmetro fixo para os estudos das propriedades mecânicas do concreto de pós reativos a idade de 28 dias.

\subsection{5- Influência do tempo pré cura térmica}

O tempo pré cura térmica é definido neste trabalho como sendo o intervalo entre o início da hidratação do cimento até o início da cura térmica, ou seja, o tempo contado a partir da inclusão da água de amassamento na mistura do concreto, até o início do aquecimento da água utilizada para realizar a cura térmica.

Esse tempo, ao qual o concreto aguarda até que se eleve a temperatura de cura, pode influenciar na resistência à compressão do concreto de pós reativos. Para analisar esse parâmetro realizaram-se ensaios experimentais, a fim de definir o comportamento da resistência àcompressão para alguns tempos pré cura térmica.

Para esses ensaios foram moldados 4 séries com 9 corpos-de-prova, onde para cada série foi determinado um tempo pré cura térmica: 6h e 30min; 1 dia; 2 dias e 3 dias. Os corpos-de-prova foram ensaiados nas idade de 7, 14 e 28 dias, em número de três.

A dosagem utilizada para estes ensaios foi a da tabela 3.18, e cura térmica a $80^{\circ} \mathrm{C}$ com duração de 16 horas. Os modelos da série com tempo pré cura térmica de 6h e 30min permaneceram a temperatura ambiente com proteção úmida na superfície exposta ao ar até o instante da cura térmica, quando foram aquecidos ainda dentro das fôrmas para preservar sua integridade. Para a série com tempo de 1 dia, os corpos-de-prova foram mantidos a temperatura ambiente com proteção úmida por 24 horas, ou seja, até o instante da cura térmica. Já para as séries com tempo pré cura térmica de 2 e 3 dias, os modelos ficaram a temperatura ambiente com proteção 
úmida por 24 horas, e em seguida foram retirados das fôrmas e levados para câmara úmida onde permaneceram até o instante da cura térmica. Após a cura térmica de 16 horas, os corpos-de-prova foram colocados na câmara úmida até a data do ensaio.

O resultado da resistência à compressão média dos três corpos-de-prova de cada série aos 28 dias são mostrados na figura 3.16, onde se observou que quanto maior o tempo pré cura térmica, maior a resistência à compressão do concreto, ficando evidente a influência deste parâmetro nas propriedades do concreto de pós reativos.

Analisando a figura 3.16, percebe-se que o crescimento da resistência à compressão ocorreu de forma não linear, onde o aumento dessa resistência entre a idade de 6 horas e a de 7 dias foi de 9,5\%, já entre os tempos de 2 dias e 3 dias, a resistência à compressão aumentou 1,8\%. Com isso, conclui-se que o aumento do tempo pré cura térmica influencia na resistência à compressão do concreto de pós reativos, no entanto, provavelmente existe um ponto a partir do qual essa influência seja praticamente nula.

Uma explicação para esse fato constatado pode ser a seguinte: o aumento do tempo pré cura térmica faz com que se tenha uma matriz com maior quantidade de partículas de cimento hidratado, que sob elevadas temperaturas, acelera o crescimento da resistência à compressão. Para pequenos tempos pré cura térmica, essa quantidade é menor, diminuindo o efeito da cura térmica.

Os ensaios mostraram que se alcançou maiores resistências com tempo pré cura térmica de 3 dias, mas a diferença entre os resultados com 2 e 3 dias eram menores que $2 \%$. Assim, adotou-se o tempo pré cura térmica de 2 dias para os estudos das propriedades mecânicas do concreto de pós reativos .

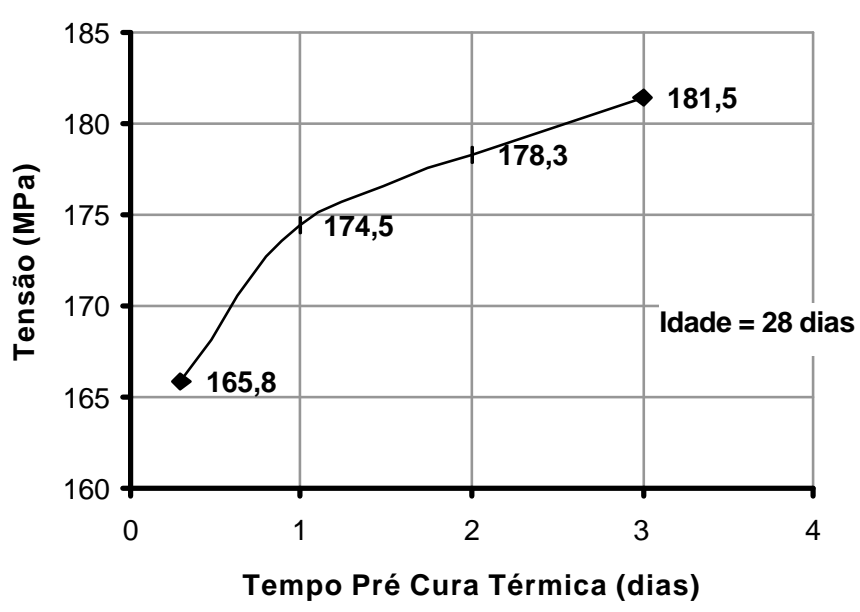

Figura 3.16 - Resistência à compressão em função do tempo pré cura térmica. 


\subsection{6- Influência do tempo de cura térmica}

A cura térmica foi feita submergindo os modelos em água, a qual era aquecida gradualmente até atingir a temperatura desejada, e mantida constante por um determinado período. Em seguida, fazia-se o resfriamento até a temperatura ambiente. O tempo de cura térmica correspondia ao período compreendido entre o início do aquecimento até o fim do resfriamento da água.

Para analisar a influência do tempo de cura térmica na resistência à compressão do concreto de pós reativos, foram moldados 3 séries de 9 corpos-deprova, onde para cada série foi determinado um tempo de cura térmica: 16horas; 24 horas e 48 horas. Os corpos-de-prova foram ensaiados nas idade de 7, 14 e 28 dias, em número de três.

A dosagem utilizada para estes ensaios foi apresentada na da tabela 3.18, com temperatura de cura de $80^{\circ} \mathrm{C}$. Depois de moldados, os modelos permaneceram a temperatura ambiente com proteção úmida na superfície exposta ao ar por 1 dia, e em seguida submetidos a cura térmica. Passado o período de cura, os corpos-de-prova foram colocados na câmara úmida até a data do ensaio.

Os resultados dos ensaios são mostrados na figura 3.17, onde pode-se notar que o aumento do tempo de cura térmica provocou crescimento da resistência à compressão do concreto de pós reativos. Para os concretos com pouca idade, a influência do tempo de cura foi maior, onde se observou para os concretos com 7 dias de idade, crescimento de $50 \%$ na resistência à compressão entre o tempo de cura térmica de 16 horas e 48 horas. No entanto, observou-se também que aos 28 dias de idade esse mesmo aumento na resistência àcompressão ficou em 15\%, evidenciando o maior efeito do tempo de cura térmica nas primeiras idades.

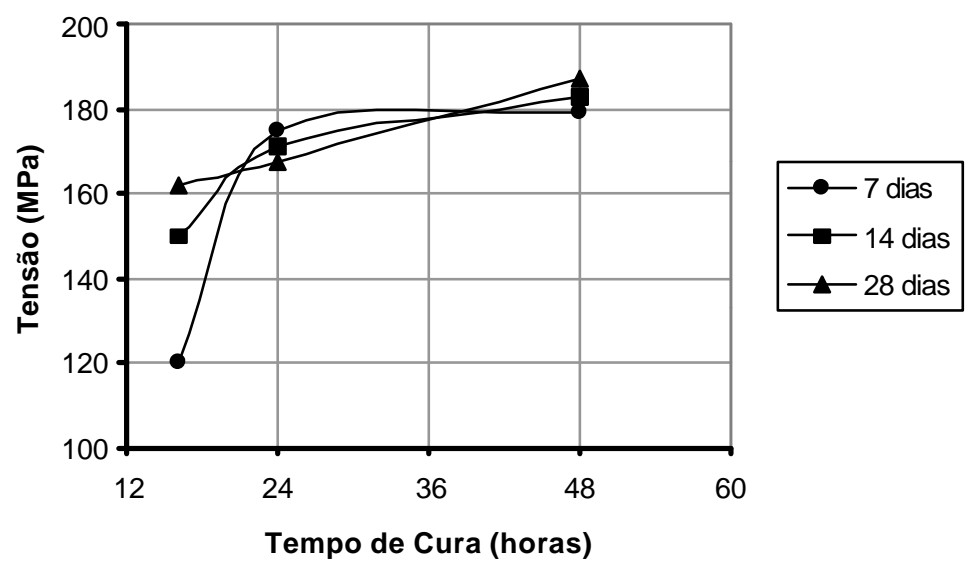

Figura 3.17 - Resistência à compressão em função do tempo de cura térmica. 
Com esses ensaios, percebeu-se que o aumento no tempo de cura térmica acelera o crescimento da resistência à compressão do concreto de pós reativos. Entretanto, a velocidade de crescimento é maior para tempos até 24 horas, onde se observou o aumento de $46 \%$ na resistência à compressão para as idades de 7 dias. Entre 24 horas e 48 horas, o ganho de resistência foi menos acentuado.

Baseado nos resultados dos ensaios, adotou-se como parâmetro para o estudo das propriedades do concreto de pós reativos o tempo de cura térmica equivalente ao período de 24 horas.

\subsection{7- Influência do tipo de cimento e temperatura da água de amassamento}

O cimento é o principal ingrediente para obtenção do concreto. Existem atualmente grande variedade de cimento no mercado, que apresentam diferentes propriedades, as quais devem ser utilizadas da maneira mais eficaz. A composição do cimento é um fator muito importante a ser considerado no estudo de sua hidratação, podendo proporcionar diferentes resultados para cada tipo de cimento.

Outro ponto que pode interferir na hidratação do cimento é a temperatura da água de amassamento, que representa a água necessária para hidratação dos grãos de cimento e também para trabalhabilidade do concreto. A temperatura dessa água pode acelerar ou retardar a hidratação.

Para o estudo desses dois parâmetros, realizaram-se ensaios com dois tipos de cimento e água de amassamento a temperatura ambiente e resfriada. Os ensaios realizados consistiram em 4 séries de 12 corpos-de-prova, que foram preparados de acordo com a dosagem da tabela 3.18, e, em seguida, após 24 horas, estes foram submetidos a cura térmica com temperatura de $80^{\circ} \mathrm{C}$ por um período de 16 horas. $\mathrm{O}$ programa experimental para este estudo é mostrado na tabela 3.22.

Tabela 3.22 - Programa de ensaio para análise do tipo de cimento e temperatura da água

\begin{tabular}{c|c|c|c}
\hline Série & Cimento & Água de Mistura & Quantidade de CP's \\
\hline 1 & CP V ARI - RS & Resfriada & 12 \\
\hline 2 & CP V ARI - RS & Temperatura ambiente & 12 \\
\hline 3 & CP V ARI - PLUS & Resfriada & 12 \\
\hline 4 & CP V ARI - PLUS & Temperatura ambiente & 12 \\
\hline
\end{tabular}

Para o estudo do tipo de cimento a ser adotado nesta pesquisa, escolheram-se dois tipos: CP V ARI-RS e CP V ARI-PLUS, ambos da marca Ciminas Cimento. A água foi utilizada de duas maneiras com temperaturas diferentes: uma a temperatura ambiente, proveniente do sistema de abastecimento de água do laboratório, que variava a sua temperatura entre $20^{\circ} \mathrm{C}$ e $25^{\circ} \mathrm{C}$; e a outra era água resfriada na geladeira, a qual atingia temperaturas entre $1^{\circ} \mathrm{C}$ e $6^{\circ} \mathrm{C}$. 
Os resultados desses ensaios mostraram que os corpos-de-prova da série 1 atingiram resistência à compressão aos 28 dias de $175 \mathrm{MPa}$, já os da série 2 , a resistência à compressão apresentou uma queda de 8,5\% com tensões de $160 \mathrm{MPa}$. Para os corpos-de-prova da série 3, a resistência à compressão foi de $140 \mathrm{MPa}$, representando apenas $80 \%$ da tensão alcançada pela série 1, e os corpos-de-prova da série 4 apresentaram tensão máxima á compressão de apenas 130,5MPa.

Logo, as maiores resistências foram atingidas com o cimento do tipo CP V ARI - RS e utilizando água com baixa temperatura. Com isso adotou-se esses dois parâmetros para definir a dosagem padrão, a ser utilizada nos estudos das propriedades do concreto de pós reativos.

\subsection{8- Influência das fibras}

O concreto de pós reativos mostrou ser um material muito frágil, capaz de perder suas propriedades mecânicas ao aparecimento das primeiras fissuras. Essa propriedade limita bastante sua aplicação, principalmente quando se trata de peças de concreto com função estrutural.

Para diminuir a fragilidade pode-se adicionar a esse concreto fibras de pequenas dimensões, que agem na matriz como pontes de transmissão de tensões entre as fissuras.

A influência das fibras na resistência àcompressão do concreto de pós reativos foi analisada moldando-se corpos-de-prova com a dosagem da tabela 3.18, adicionando-se diferentes quantidades de fibras. As fibras utilizadas seguem as especificações descritas no item 2.1.4, onde indica fibras metálicas de comprimento de $13 \mathrm{~mm}$ e diâmetro de $0,15 \mathrm{~mm}$ de formato reto.

As taxas de fibras, em volume, estabelecidas para estes ensaios foram: $0 \%$, $0,5 \%, 1 \%, 2 \%, 3 \%$ e $4 \%$.

Os modelos foram submetidos a cura térmica com temperatura de $80^{\circ} \mathrm{C}$ por 16 horas e ensaiados nas idades de 7, 14, 28, 63 e 91 dias.

Os resultados dos ensaios são expostos nas figuras 3.18 e 3.19, que mostram o crescimento da resistência àcompressão do concreto de pós reativos em função da idade e da quantidade de fibras. Por meio destes gráficos, verifica-se que os modelos sem fibras apresentaram crescimento na resistência à compressão até os 28 dias de idade, permanecendo com resistência estável a partir desta data. Para os modelos contendo fibras, o comportamento foi diferente, pois notou-se que a resistência à compressão se estabilizou a partir dos 7 dias de idade. 
Acredita-se que esse aumento da resistência àcompressão nos primeiros dias, quando adiciona-se fibras ao concreto, deve-se a diminuição da fragilidade do material. Em virtude da baixa quantidade de água neste tipo de concreto, a hidratação do cimento se dá de forma não homogênea, causando, principalmente nas primeiras idades, regiões com diferentes propriedades mecânicas dentro da massa de concreto. Quando o modelo é submetido a tensões, as regiões menos hidratadas da massa de concreto apresentam fissuras para intensidades de tensões mais baixas que outras regiões, causando a ruptura prematura do modelo. Neste caso, as fibras atuam como pontes de transferência de tensões entre as regiões mais hidratadas, fazendo com que o modelo redistribua as tensões de forma mais homogênea, aumentando, assim, a resistência mecânica.

Com isso, o efeito das fibras é mais evidente nas primeiras idades, onde existem maior quantidade de regiões pouco hidratadas, ao contrário dos modelos com idades mais elevadas, onde a hidratação do cimento é mais homogênea.

Observou-se também que o aumento do volume de fibras no concreto provocou crescimento da resistência à compressão. Esse efeito foi observado até a taxa de $3 \%$ de fibras onde, a partir desse valor houve tendência de queda. A diminuição da resistência a partir de um determinado volume de fibras pode ser justificada pela presença de defeitos nos modelos, em virtude de pior adensamento, já que a quantidade de fibras era grande, acarretando má trabalhabilidade.

O aumento do volume de fibras de $0,5 \%$ até $3 \%$, provocou crescimento na resistência à compressão que variou conforme a idade dos corpos-de-prova. Os modelos com 7 dias apresentaram aumento na resistências de 10,3\%; aqueles com 14 dias a diferença foi de $6,7 \%$; já para os modelos com idades de 28 dias até 91 dias, a diferença ficou em $2 \%$ (média). Essas observações levam a crer que maior volume de fibras melhora a distribuição das tensões internas entre as regiões mais hidratadas, e que esta propriedade é mais evidenciada nas primeiras idades do concreto. Além disso, quanto maior a quantidade de fibras, maior a ductilidade do material, fazendo com que este atinja intensidade de tensões elevadas, por causa da sua maior deformabilidade.

No entanto, o aumento na quantidade de fibras tem um ponto crítico, onde a partir do qual podem ocorrer prejuízos para as propriedades mecânicas do concreto, como exposto anteriormente.

Com o aumento da quantidade de fibras na mistura, ocorreram perdas na trabalhabilidade do concreto, sendo recomendado para as próximas dosagens maior quantidade de superplastificante. 


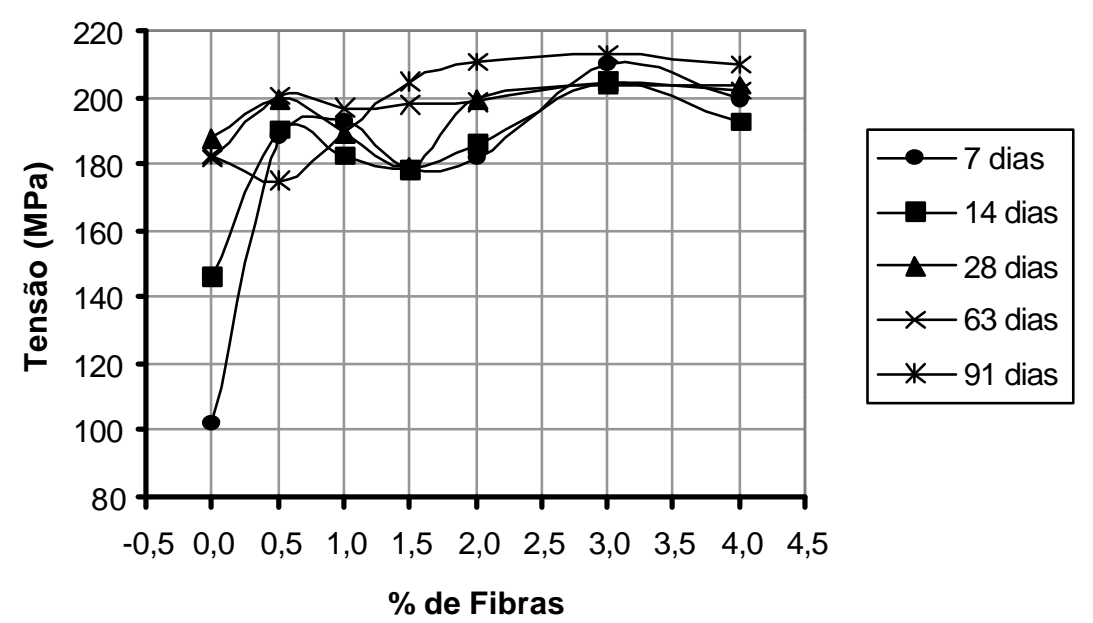

Figura 3.18 - Resistência à compressão em função do volume de fibras.

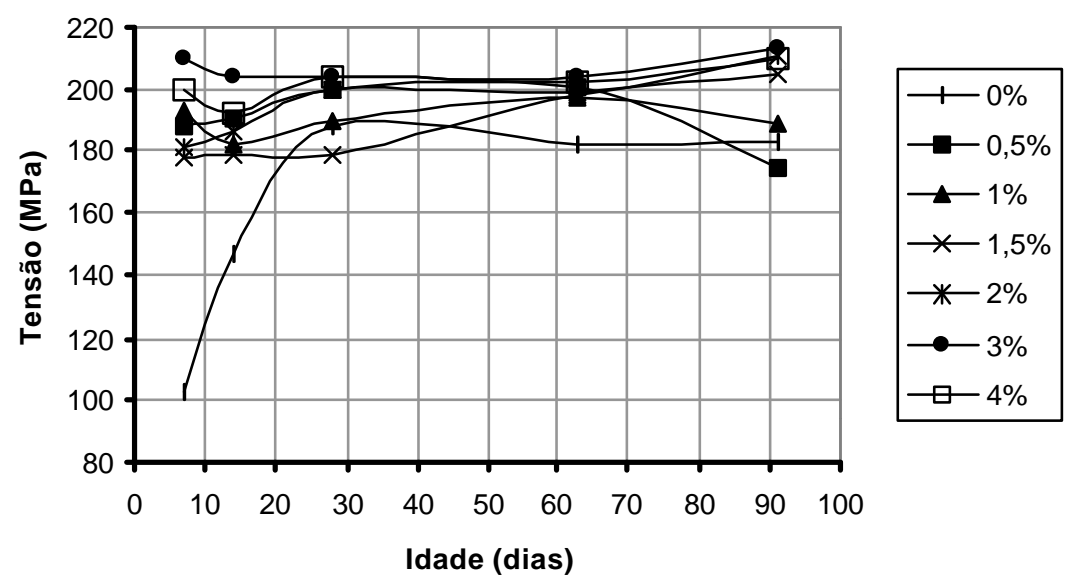

Figura 3.19 - Resistência à compressão em função da idade.

\subsection{9- Procedimentos de mistura}

O procedimento de mistura dos materiais constituintes do concreto de pós reativos, é um fator que tem influência na homogeneização da mistura, trabalhabilidade do concreto e consequentemente nas suas propriedades.

Para o concreto de pós reativos, este fator tem grande importância por causa da baixa quantidade de água utilizada, a qual gera grandes dificuldades para alcançar uma mistura homogênea e trabalhável. Contudo, analisaram-se vários procedimentos de misturas dos materiais, visando atingir um material homogêneo com boa trabalhabilidade.

De acordo com os ensaios realizados, o procedimento de mistura que apresentou melhor eficiência foi:

a- Misturar todo o material seco em um misturador eficiente até que os componentes fiquem bem dispersos, aparentando mistura homogênea, isto pode durar em torno de 3 minutos, dependendo da eficiência da máquina; 
b- Misturar a água com o superplastificante em solução única, e adicionar em pequenas doses na mistura dos pós com o misturador na velocidade máxima por 2 minutos;

c- Aguardar com o misturador em baixa velocidade por aproximadamente 5 minutos, ou até atingir a consistência esperada;

d- Para moldagem dos modelos, utilizar mesa vibratória para realizar o adensamento.

\section{5- Dosagem Proposta para o Concreto de Pós Reativos}

Com os estudos teóricos e aplicação do método do empacotamento, assim como os ensaios experimentais realizados para conhecer a influência de vários fatores na resistência à compressão do concreto de pós reativos, pode-se definir dosagem que serviu de base para os ensaios feitos neste trabalho para o estudo das propriedades mecânicas do concreto de CPR.

Assim, os parâmetros definidos neste capítulo foram:

a) Cimento do tipo CP V ARI - RS;

b) Água de amassamento com baixa temperatura;

c) Relação água/cimento de 0,18;

d) Tempo pré cura térmica de 2 dias;

e) Tempo de cura térmica de 24 horas;

f) Temperatura de cura térmica de $80^{\circ} \mathrm{C}$;

g) Idade de 28 dias para estudo das propriedades mecânicas;

Aumentando-se a taxa de superplastificante para 3\%, foi definida a dosagem da tabela 3.23 como referência para o estudo do concreto de pós reativos.

Tabela 3.23 - Dosagem desenvolvida para o estudo do concreto de pós reativos

\begin{tabular}{l|c|c}
\multicolumn{1}{c|}{ Material } & Relação $(\mathbf{e m ~ m a s s a )}$ & Consumo $\left(\mathbf{k g} / \mathbf{m}^{\mathbf{3}}\right)$ \\
\hline Cimento & 1 & 874 \\
\hline Areia & 1,101 & 962 \\
\hline Pó de Quartzo & 0,235 & 205 \\
\hline Sílica Ativa & 0,246 & 215 \\
\hline Superplastificante (3\%) & 0,030 & 26 \\
\hline Água (a/c $=0,18)$ & 0,180 & 157 \\
\hline
\end{tabular}




\section{Considerações Finais}

Com os estudos realizados sobre o método de dosagem e procedimentos de moldagem, adensamento e cura, faz-se uma análise da influência de alguns parâmetros nas propriedades do concreto de pós reativos, onde pôde-se concluir que:

- O método do empacotamento proposto por "Andreassen e Andersen", e adotado neste estudo, mostrou-se eficiente na definição das proporções de cada material, a fim de atingir uma mistura com o mínimo de vazios, e ,consequentemente, maior densidade. No levantamento bibliográfico realizado sobre dosagem de concretos de pós reativos, não foi identificado nenhum método de empacotamento, assim, este trabalho indica o método proposto por "Andreassen e Andersen", como boa ferramenta para dosagem de concreto de pós reativos;

- A relação água/cimento deve ser mínima, e adotada com muito rigor, baseada em estudos experimentais onde a lei de Abrams não é mais aplicável, procurando-se sempre o equilíbrio entre trabalhabilidade e resistência;

- Como qualquer material a base de cimento Portland hidratado, as propriedades mecânicas do concreto de pós reativos são influenciadas pela idade. No entanto, o CPR tem comportamento especial, pois apresenta elevada resistência nas primeiras idades, mesmo sem cura térmica ou adições de fibras;

- A temperatura de cura é um fator importante para definir as propriedades do concreto de pós reativos, onde temperaturas elevadas de cura proporcionam concretos mais resistentes, principalmente nas primeiras idades;

- O tempo pré cura térmica também influencia as propriedades do CPR, onde para aumentar a resistência à compressão, recomenda-se que os modelos sejam colocados em cura térmica após 2 dias de moldados, proporcionando uma maior quantidade de partículas de cimento hidratado, que atuarão durante o tratamento térmico;

- O tempo de permanência em cura térmica também deve ser estudado para melhorar as propriedades mecânicas do CPR. A maior permanência neste regime de cura proporciona uma aceleração das propriedades mecânicas, o que influencia principalmente os concretos nas primeiras idades. No entanto, esta influência é mais evidente para tempos de cura térmicas até 24 horas;

- As fibras metálicas mostraram-se um ingrediente muito importante para o CPR, elas atuam no instante do aparecimento das primeiras fissuras, provocando uma redistribuição das tensões internas, promovendo aumento da resistência à compressão e à tração, e, além disso, tornando o material mais dúctil. As fibras apresentam excelente desempenho nas primeiras idades do concreto e, quanto 
maior a quantidade de fibras, ocorre melhora nas propriedades mecânicas, exceto para a resistência à compressão, onde recomenda-se o limite de $3 \%$ do volume, pois a partir deste, o concreto tende a diminuir sua resistência, em virtude da incorporação de vazios por dificuldade de trabalhabilidade e adensamento.

- O procedimento de mistura dos materiais é um fator que influencia na homogeneidade da mistura, trabalhabilidade do concreto e consequentemente suas propriedades. Recomenda-se que, na falta de um agitador eficiente, faça-se a pré misturas dos pós, aplicando uma energia de agitação suficiente para homogeneizar a mistura. Na sequência, deve-se colocar a água juntamente com o superplastificante, e continuar a homogeneizar até que se alcance a trabalhabilidade esperada, só então deve-se adicionar as fibras, e prosseguir com a homogeneização. A moldagem pode ser feita com adensamento mecânico, principalmente quando utilizam-se taxas elevadas de fibras.

- A cura dos modelos deve se iniciar logo após o término da moldagem, primeiramente com cura úmida e, posteriormente, a cura térmica; 


\section{CAPÍtULO}

\section{ANÁLISE EXPERIMENTAL}

\section{Considerações Iniciais}

Este capítulo descreve a metodologia adotada no desenvolvimento experimental para o estudo de algumas propriedades mecânicas do concreto de pós reativos, a partir da dosagem elaborada no capítulo 3.

São abordados todos os procedimentos envolvidos na experimentação, tais como:

- Programa experimental, definindo os parâmetros analisados e os tipos de ensaios necessários;

- Materiais utilizados para compor o concreto de pós reativos, dosagem, elaboração de fôrmas, moldagem, adensamento e cura dos modelos;

- Sistema de aplicação de força e de vinculação, para os ensaios de compressão axial e flexão em 4 pontos;

- Instrumentação adotada e coleta dos dados para cada tipo de ensaio;

- Descrição dos ensaios realizados. 
A partir da dosagem desenvolvida para concreto de pós reativos, com materiais selecionados obtidos na região, e procedimentos adequados que proporciona resistência à compressão próxima de $200 \mathrm{MPa}$, partiu-se para o estudo de algumas propriedades mecânicas de relevante importância para análise do comportamento estrutural de elementos construídos com esse material.

Assim, analisaram-se as propriedades do concreto de pós reativos desenvolvido a fim de esclarecer o comportamento deste material com relação a:

- Evolução da resistência àcompressão com o tempo;

- Relação entre tensão e deformação axial;

- Módulo de deformação longitudinal;

- Resistência àtração na flexão;

- Deformações máximas na tração e na compressão;

- Ductilidade do material;

- Influências da quantidade de fibras nas propriedades mecânicas e ductilidade;

\section{1- Metodologia Experimental}

A metodologia adotada para desenvolver o estudo experimental da pesquisa, compreendeu:

- Definição dos parâmetros fixos, variáveis e os que foram medidos durante os ensaios;

- Dosagem adotada;

- Tipos de ensaios necessários;

- Propriedades dos modelos ensaiados, definindo dimensões e fôrmas;

- Sistema de aplicação de força e vinculação;

- Instrumentação necessária para coletar os dados dos ensaios;

\section{2- Programa Experimental}

A resistência à compressão ao longo do tempo, a relação entre tensão e deformação axial e o módulo de deformação longitudinal, foram analisadas por meio de ensaios de compressão axial, onde, em virtude da fragilidade do material e com a intenção de tentar verificar o comportamento pós-ruptura, adotaram-se ensaios com controle de deformação.

Para a resistência àtração na flexão, foi adotado ensaio de flexão em prismas com forças nos terços do modelo, conhecido como ensaio de flexão a 4 pontos, e a força era aplicada com controle de deslocamento. 
As deformações máximas na tração e na compressão, e a ductilidade do material foram analisados por meio dos ensaios de compressão axial e flexão de prismas.

Para analisar a resistência àcompressão com relação ao tempo, adotaram-se como parâmetros fixos as idades de 7, 14, 28, 63 e 91 dias, onde para cada idade eram ensaiados 3 modelos idênticos, e o resultado considerado era a média aritmética.

O módulo de deformação longitudinal e a resistência àtração na flexão foram medidos em concretos com 28 dias de idade, e também utilizando 3 modelos para cada ensaio.

O efeito da quantidade das fibras metálicas nas propriedades do concreto de pós reativos, foi analisado moldando-se seis séries de modelos com taxas de fibras em volume iguais a: $0 \%, 0,5 \%, 1 \%, 2 \%, 3 \%$ e $4 \%$. A dosagem para todas as séries foi a mesma, a fim de manter como parâmetro fixo a resistência àcompressão no valor de 200MPa, alterando-se apenas a quantidade de fibras.

Assim, o programa experimental para o estudo das propriedades mecânicas do concreto de pós reativo foi definida conforme mostra a tabela 4.1.

Tabela 4.1- Programa experimental

\begin{tabular}{|c|c|c|c|c|}
\hline \multirow[b]{2}{*}{ Séries } & \multirow{2}{*}{$\begin{array}{c}f_{c} \\
(\mathbf{M P a})\end{array}$} & \multirow{2}{*}{$\begin{array}{c}\text { Fibra } \\
(\%)\end{array}$} & \multicolumn{2}{|c|}{ Quantidade de modelos } \\
\hline & & & $\begin{array}{c}\text { Compressão axial } \\
5 \mathrm{~cm} \times 10 \mathrm{~cm}\end{array}$ & $\begin{array}{c}\text { Flexão } 4 \text { pontos } \\
5 \mathrm{~cm} \times 5 \mathrm{~cm} \times 34 \mathrm{~cm}\end{array}$ \\
\hline M1 & 200 & 0 & 18 & 3 \\
\hline M2 & 200 & 0,5 & 18 & 3 \\
\hline M3 & 200 & 1 & 18 & 3 \\
\hline M4 & 200 & 2 & 18 & 3 \\
\hline M5 & 200 & 3 & 18 & 3 \\
\hline M6 & 200 & 4 & 18 & 3 \\
\hline
\end{tabular}

\section{3- Particularidades dos Ensaios}

Como visto, os ensaios realizados nesta pesquisa foram os de compressão axial e flexão em 4 pontos, conforme exposto na tabela 4.1 .

Para cada tipo de ensaio, foram definidos: propriedades físicas dos modelos ensaiados; sistema de aplicação de força; e a instrumentação utilizada para medir os dados dos ensaios.

\subsection{1- Ensaios de Compressão Axial}

Para os ensaios de compressão axial, foram adotados modelos de forma cilíndrica com dimensões de $50 \mathrm{~mm}$ de diâmetro por $100 \mathrm{~mm}$ de altura. As dimensões foram adotadas de acordo com as recomendações normativas para propriedades 
mecânicas do concreto, as quais estabeleceu que a dimensão mínima dos modelos deveram ser maiores que três vezes a dimensão máxima do agregado.

Considerando que o comprimento da fibra metálica era igual a $13 \mathrm{~mm}$ e, fazendo-se analogia com o agregado, os corpos-de-prova devem ter dimensão mínima igual a $39 \mathrm{~mm}$.

Outra condição a ser analisada é a capacidade de carga dos equipamentos disponíveis. Para atingir tensão de 230MPa, utilizando corpos-de-prova com seção de aplicação de força de $50 \mathrm{~mm}$ de diâmetro, seria necessário uma força de $451 \mathrm{kN}$, o que não é difícil de se obter com a maioria dos equipamentos de aplicação de carga. No entanto, se fossem utilizados corpos-de-prova com diâmetro de $100 \mathrm{~mm}$, seria necessário uma força de $1.860,0 \mathrm{kN}$, levando a maioria dos equipamentos ao seu limite de segurança.

Portanto, os modelos adotados para os ensaios de compressão axial foram corpos-de-prova cilindros com dimensões de $50 \mathrm{~mm}$ de diâmetro por $100 \mathrm{~mm}$ de altura; como fôrmas foram adotados moldes metálicos utilizados normalmente para estudo de argamassas, conforme figura 4.1 .
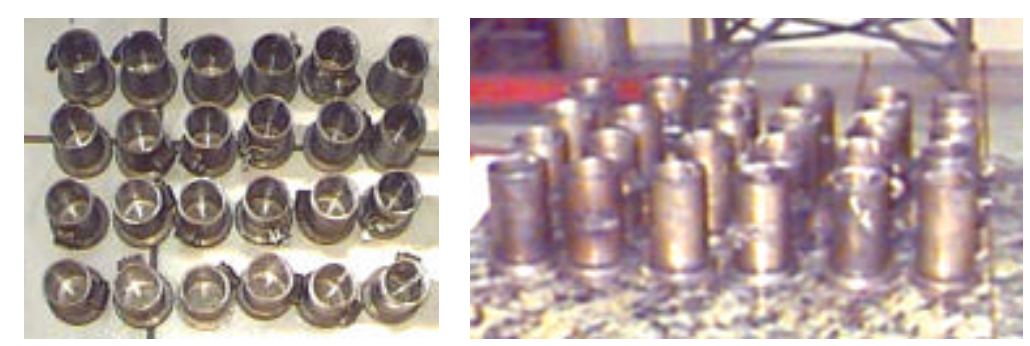

Figura 4.1- Fôrmas para os modelos dos ensaios de compressão axial

\subsubsection{1- Sistema de aplicação de força e vinculação}

Os ensaios de compressão axial para análise da resistência àcompressão ao longo do tempo, foram realizados na prensa da marca "ELE' do Laboratório de Estruturas da EESC - USP, figura 4.2, que tem capacidade de carga de $2000 \mathrm{kN}$. O carregamento era aplicado com controle de força a taxa de $0,5 \mathrm{kN} / \mathrm{s}$.

Os corpos-de-prova eram colocados entres as placas de aço, bem ao centro, para que a força atuasse de forma centrada. As bases dos corpos-de-prova eram posicionadas sobre placa de aço fixa, enquanto que o topo ficava sob placa de aço vinculada a uma rótula, figura 4.3, a fim de facilitar a atuação centrada da ação. 


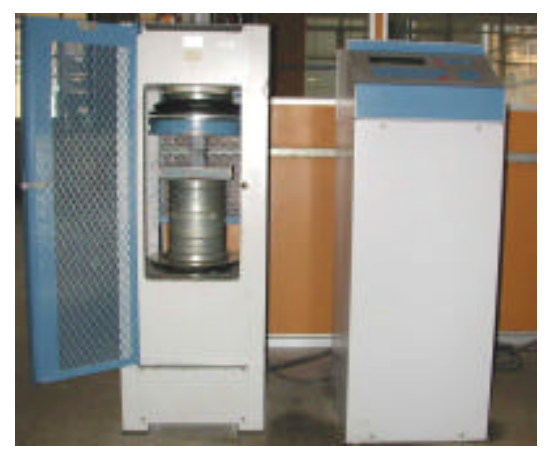

Figura 4.2- Prensa "ELE" para ensaios de compressão axial.

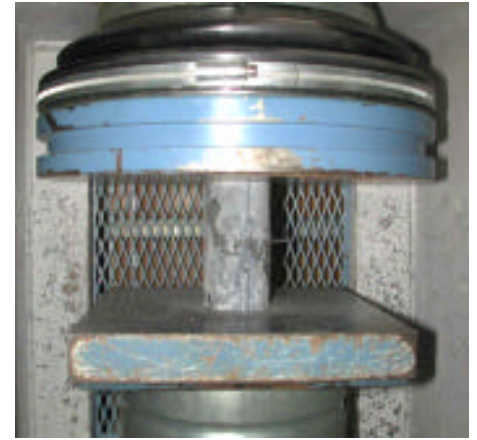

Figura 4.3- Vinculação dos modelos.

Os ensaios de compressão axial para análise do módulo de deformação longitudinal, foram realizados no Laboratório de Mecânica das Rochas do Departamento de Geotecnia da EESC - USP. Foi utilizado prensa da marca 'MTS', com capacidade de carga de $3000 \mathrm{kN}$, a qual proporcionava aplicação de força com controle da velocidade de deslocamento do atuador, figura 4.4.

Os modelos também foram apoiados entre placas de aço, onde a inferior era fixa e a superior rotulada. Para ajustar a altura dos modelos, foram utilizados cilindros de aço conforme mostrado na figura 4.5 .

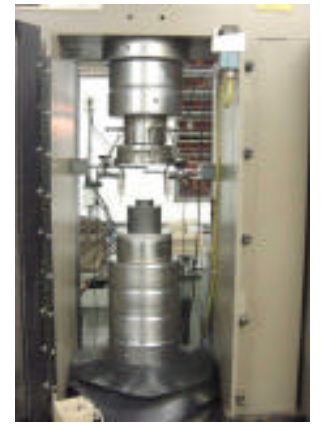

Figura 4.4- Prensa "MTS" para ensaios de compressão axial com controle de deslocamento.

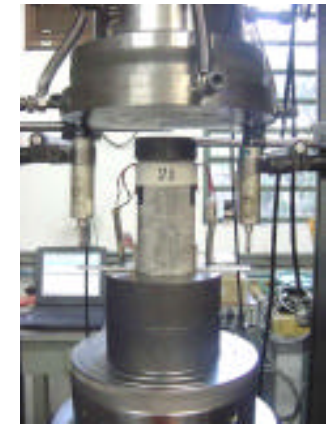

Figura 4.5- Vinculação dos modelos.

Por causa da alta intensidade de tensão atingida durante os ensaios, alguns modelos se rompiam de forma brusca lançando estilhaços de concreto ao seu redor. Para proteger os equipamentos e instrumentos de medição, os corpos-de-prova eram envolvidos com dispositivo de madeira desenvolvido no Laboratório de Materiais Avançados a Base de Cimento Portland da EESC - USP, conforme mostrado nas figuras 4.6 e 4.7 . 


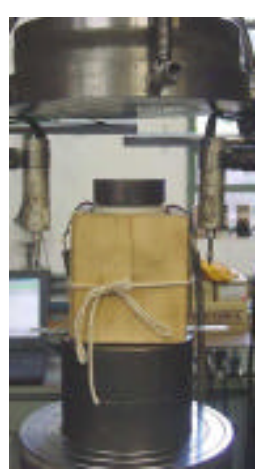

Figura 4.6- Dispositivo de proteção para ensaios de compressão em concretos de alta resistência.

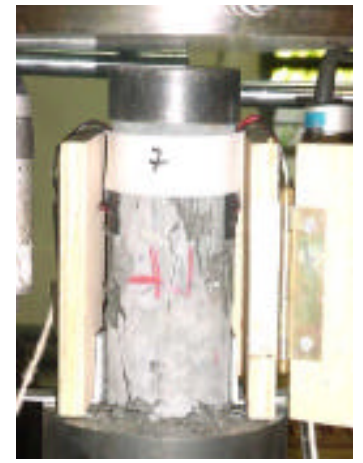

Figura 4.7- Dispositivo de proteção com modelo rompido.

\subsubsection{2- Instrumentação}

Nos ensaios de compressão axial para análise da resistência ao longo do tempo, foi monitorado apenas a força máxima aplicada pela prensa, a qual provocou a ruptura dos modelos. Para isso, o prensa utilizada para aplicação da força possuía célula de carga com dispositivo automático, que detectava o valor máximo atingido, e o registro era feito de forma digital.

Os ensaios para análise do módulo de deformação longitudinal precisavam medir a força aplicada e a deformação longitudinal. Para isso, foram colocados nos modelos dois extensômetros elétricos de resistência a meia altura e diametralmente opostos, conforme figuras 4.8 e 4.9 .

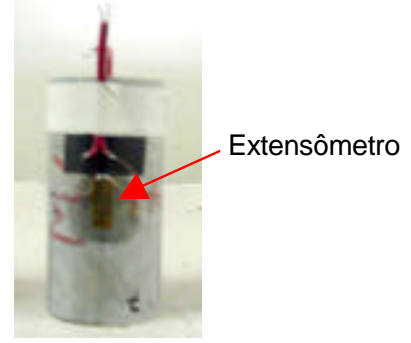

Figura 4.8- Extensômetro colocado a meia altura do modelo.

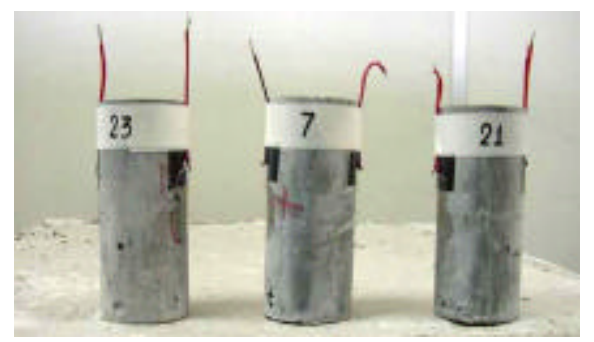

Figura 4.9- Extensômetros colocados diametralmente opostos.

Além das medidas dos extensômetros, colocaram-se dois transdutores de deslocamento para medir o deslocamento da base dos modelos, figura 4.10, e também fez-se o registro do deslocamento do êmbolo do atuador hidráulico.

A força aplicada era medida por célula de carga da própria prensa, assim como, o deslocamento do atuador hidráulico, que se deslocava com velocidade pré definida, pois o ensaio era realizado com controle de deslocamento.

Assim, a instrumentação dos modelos utilizados nos ensaios de compressão axial com controle de deslocamento foi definida conforme mostra a figura 4.10. 


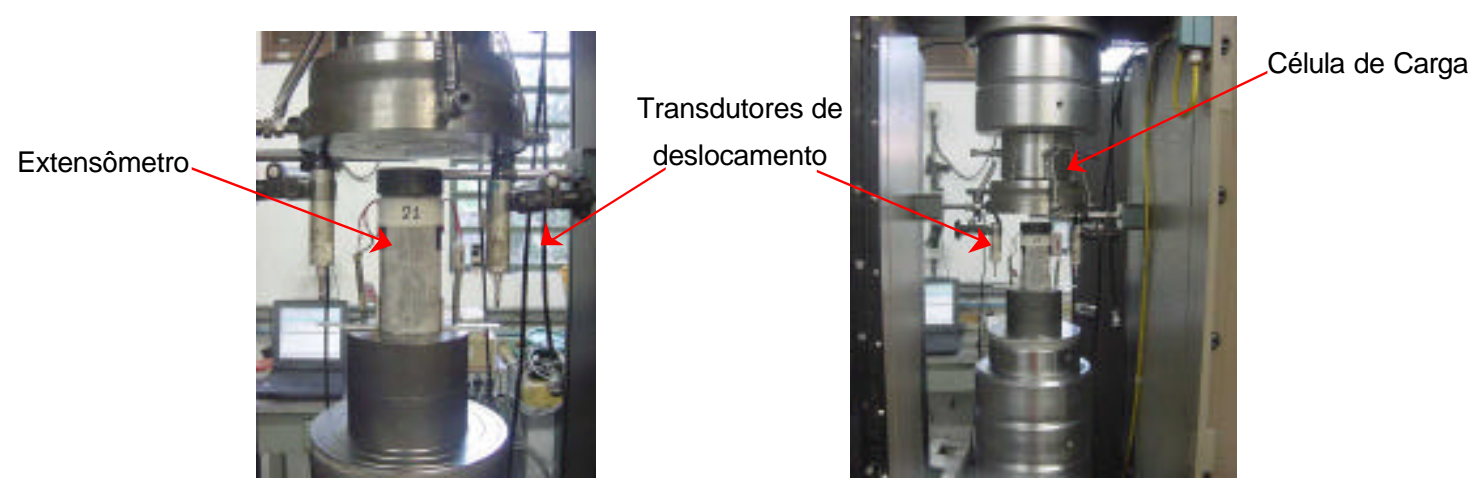

Figura 4.10- Instrumentação dos modelos ensaiados a compressão axial.

As leituras dos dados eram feitas por meio do sistema de aquisição de dados digital, composto por um computador com o software de controle do Sistema 5000, o qual eram conectados módulos que codificavam a leitura dos instrumentos, figura 4.11.

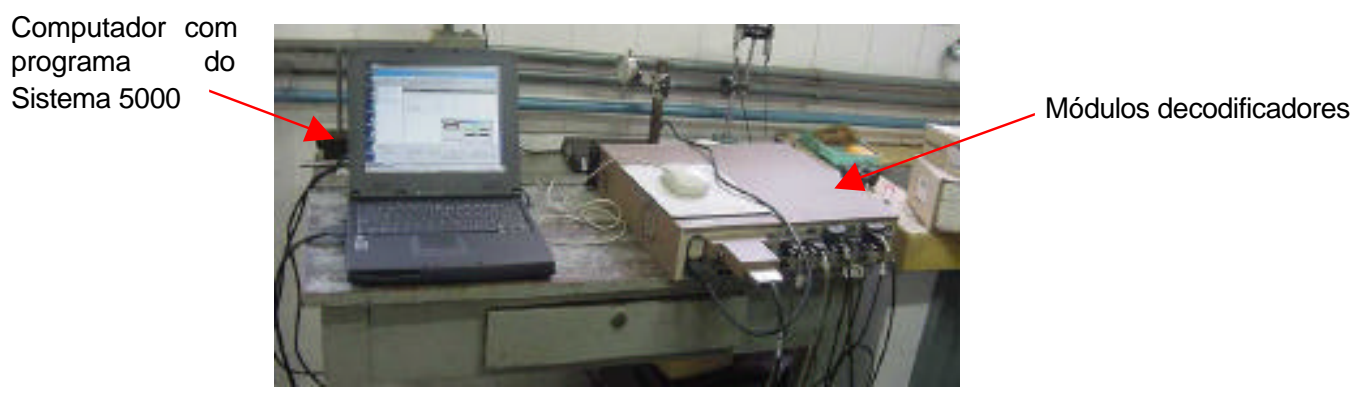

Figura 4.11- Sistema de aquisição de dados.

\subsection{2- Ensaios de flexão a 4 pontos}

Como visto no item 4.3.1, a menor dimensão do modelo deve ser de $39 \mathrm{~mm}$, assim, determinou-se que as medidas da seção transversal do prisma eram de $50 \mathrm{~mm}$ x 50mm. O ensaio adotado foi o de flexão com forças aplicadas nos terços do modelo, com isso, determinou-se que o comprimento teórico seria de $300 \mathrm{~mm}$, onde cada terço teria $100 \mathrm{~mm}$ de comprimento. No entanto, o prisma foi construído com $20 \mathrm{~mm}$ de folga de cada lado, para facilitar o posicionamento sobre os apoios, resultando em comprimento total de $340 \mathrm{~mm}$.

Então, os modelos adotados para os ensaios de flexão foram prismas com dimensões de $50 \mathrm{~mm}$ de base, $50 \mathrm{~mm}$ de altura, e $340 \mathrm{~mm}$ de comprimento, conforme figura 4.12 . 


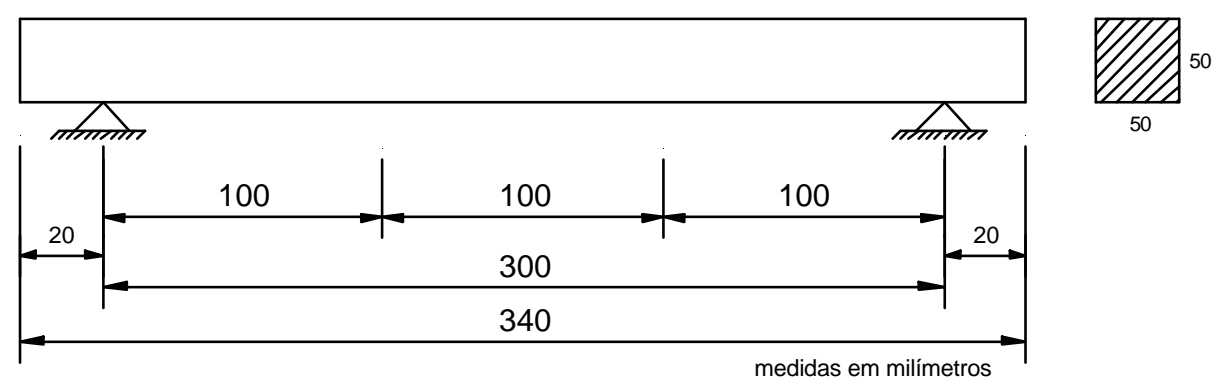

Figura 4.12- Modelo prismático para ensaios de flexão.

Para moldar esses prismas, foi fabricada uma fôrma metálica, desmontável, capaz de moldar três modelos simultaneamente, conforme mostram as figuras $4.13 \mathrm{e}$ 4.14.

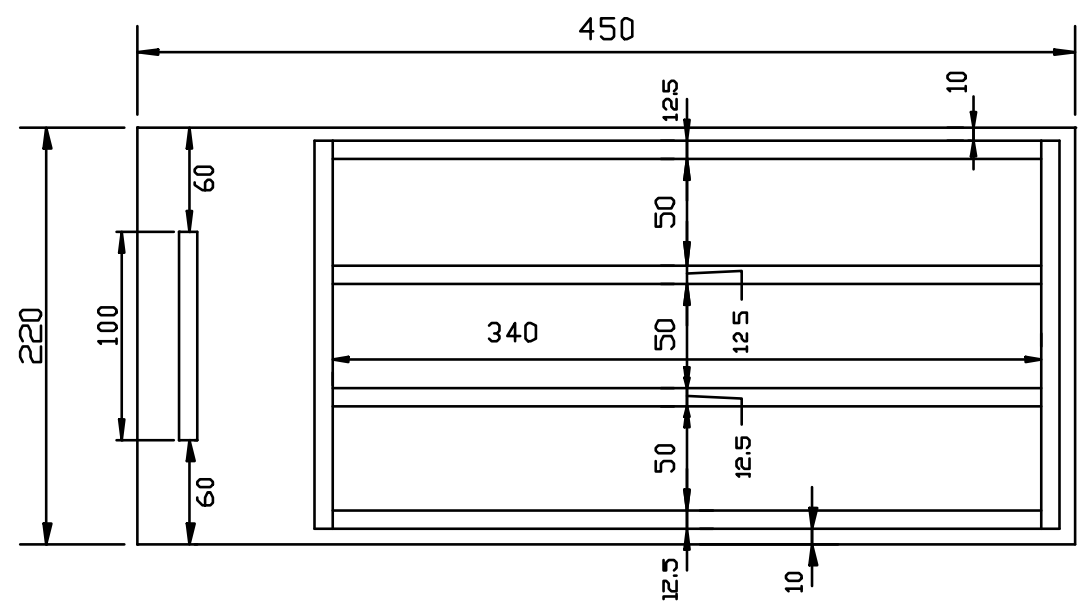

Figura 4.13- Dimensões da fôrma para os modelos prismáticos.

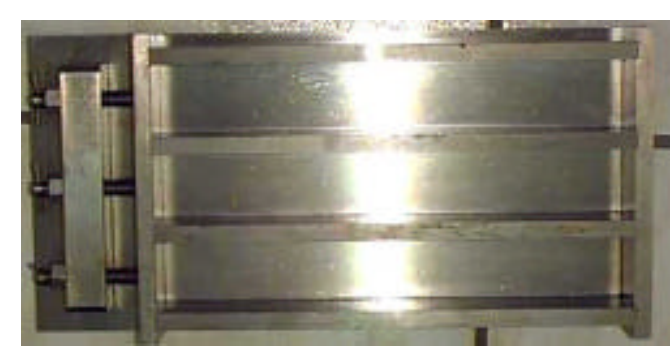

Figura 4.14- Fotografia da fôrma metálica para os modelos prismáticos.

\subsubsection{1- Sistema de aplicação de força e vinculação}

Os ensaios de flexão para análise da resistência à tração na flexão foram realizados na prensa da marca "MTS", do Laboratório de Mecânica das Rochas da EESC - USP, com capacidade de carga de $3000 \mathrm{kN}$, a qual proporcionava aplicação de força com controle de deslocamento, figura 4.15.

Os modelos eram posicionados sobre dispositivo próprio para este tipo de ensaio, figura 4.16, onde os apoios eram cilindros metálicos que permitiam rotação dos pontos em contato. 


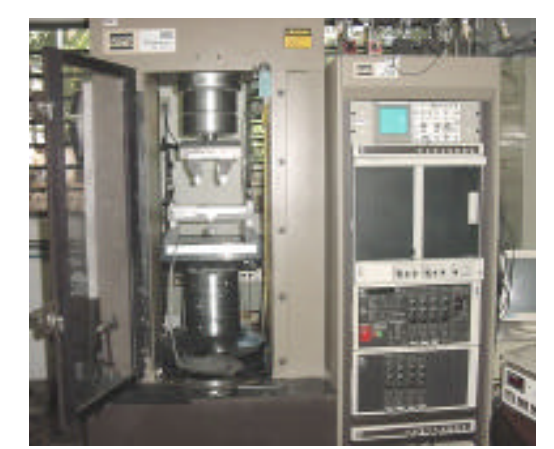

Figura 4.15- Prensa "MTS" para ensaios de flexão com controle de deslocamento.

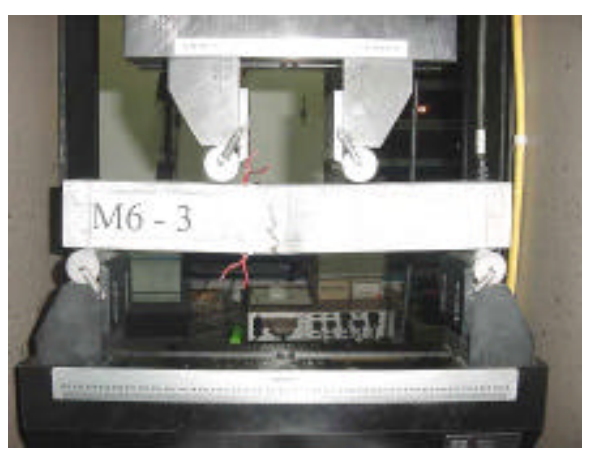

Figura 4.16- Vinculação dos modelos.

\subsubsection{2- Instrumentação}

Nos ensaios de flexão a 4 pontos, os modelos foram instrumentados conforme mostra a figura 4.17, onde foram medidas para seção central o seu deslocamento vertical e as deformações nas fibras superior e inferior, além da força aplicada. Esses dados foram registrados durante todo o ensaio com frequência de 1 segundo.

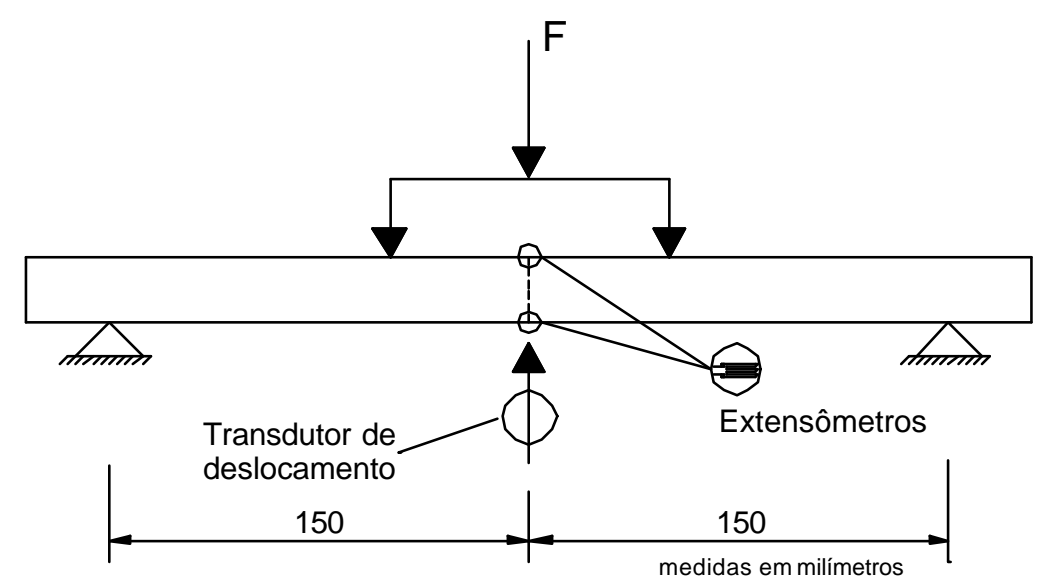

Figura 4.17- Instrumentação dos modelos nos ensaios de flexão a 4 pontos.

Para medir o deslocamento vertical, utilizou-se um transdutor de deslocamento (LVDT), acoplado ao "Dispositivo de Bernier", figura 4.18 e 4.19. Esse dispositivo permitiu medir com maior precisão o deslocamento ocorrido na seção central do modelo, sem a interferência dos deslocamentos nos apoios, ou seja, as acomodações do sistema não causavam perturbação na leitura dos deslocamentos do ponto médio.

O transdutor de deslocamento (LVDT) era colocado no dispositivo de Bernier, o qual permanecia sempre em repouso com relação ao modelo, sem sofrer interferência dos deslocamentos dos apoios e das rotações das seções extremas. O cursor do LVDT era apoiado sobre uma lâmina de alumínio que ficava fixada com cola acrílica no ponto onde pretendia-se medir o deslocamento, ou seja, na seção central, figura 4.20. Com a aplicação da força, o modelo se deformava e a lâmina de alumínio 
deslocava-se para baixo, acompanhada pelo cursor do LVDT, medindo-se assim, o deslocamento desejado durante o ensaio.

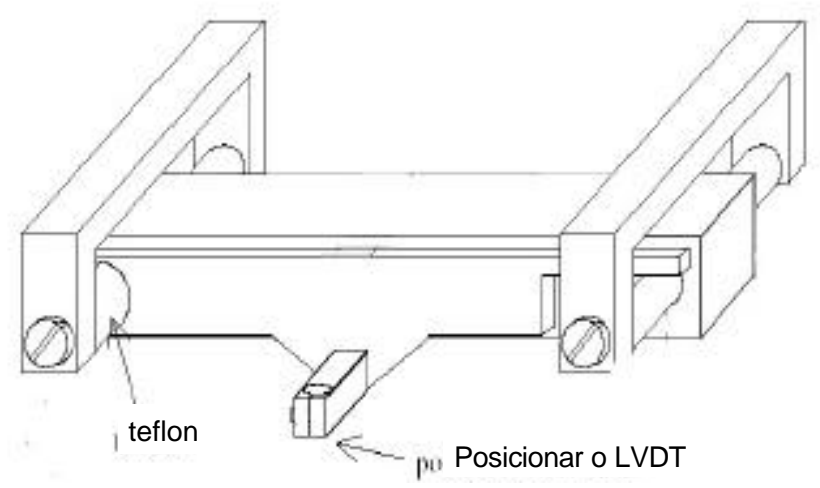

Figura 4.18- Dispositivo de Bernier.

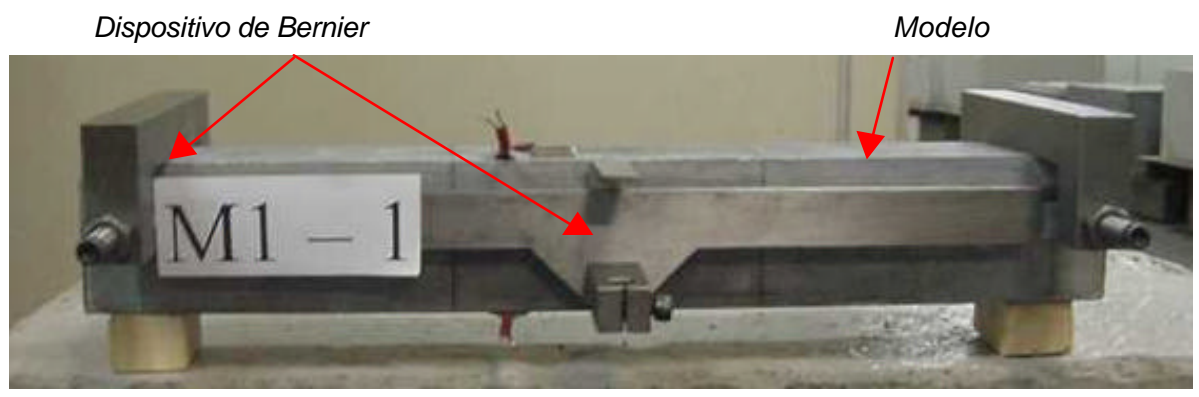

Figura 4.19- Modelo com o dispositivo de Bernier acoplado.

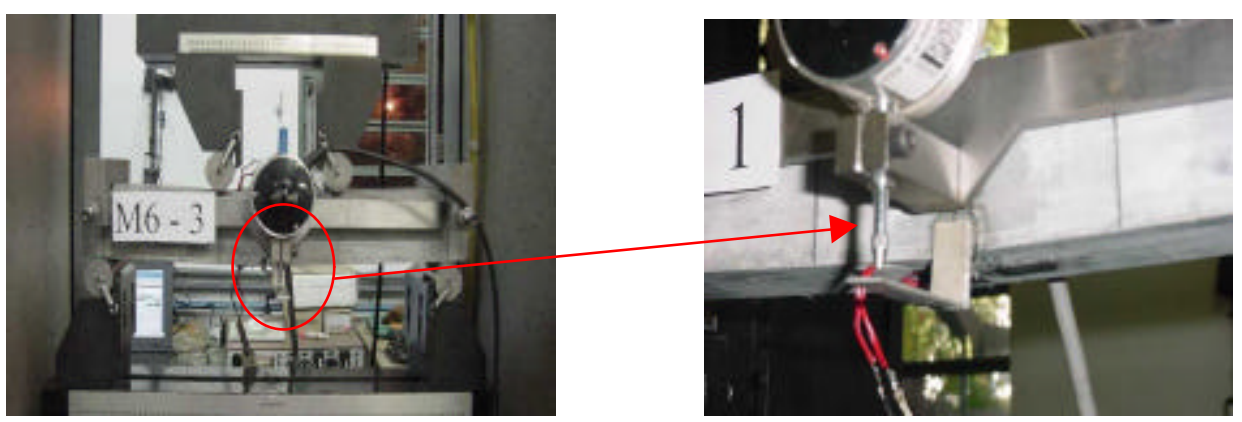

Figura 4.20- Modelo submetido ao ensaio de flexão a 4 pontos.

As deformações de tração e compressão na seção central foram medidas com extensômetros elétricos, que eram fixados nas bordas inferior e superior da seção, como mostra a figura 4.21 .

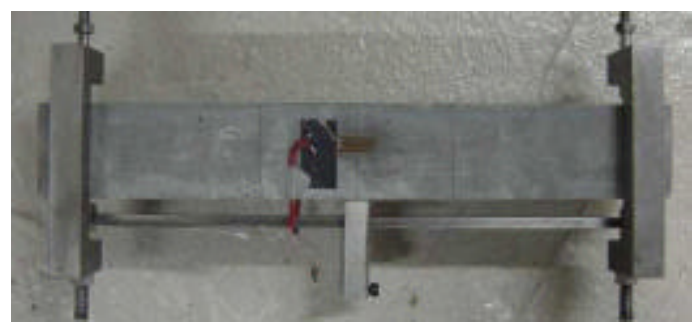

Figura 4.21- Extensômetro fixado na borda superior da seção central. 
A força aplicada era registrada com célula de carga da própria prensa, assim como o deslocamento do atuador hidráulico, que se deslocava com velocidade pré definida, pois o ensaio era realizado com controle de deslocamento.

As leituras dos dados eram feitas com o mesmo sistema de aquisição de dados, mostrado para os ensaios de compressão axial, figura 4.11.

\section{4- Materiais Utilizados e Dosagem Adotada}

Os materiais adotados para compor o concreto de pós reativo utilizado neste estudo, foram definidos, conforme descrito no item 3.2 do capítulo 3.

A dosagem utilizada é apresentada na tabela 3.23, desenvolvida conforme descrito nos itens 3.3 e 3.4, com adições de fibras metálicas de acordo com as séries do programa experimental estabelecido na tabela 4.1. O consumo dos materiais para cada série está relacionado na tabela 4.2.

Tabela 4.2 - Dosagem utilizada no estudo do concreto de pós reativos

\begin{tabular}{|c|c|c|c|c|c|c|c|}
\hline \multirow{2}{*}{ Material } & \multirow{2}{*}{$\begin{array}{c}\text { Relação } \\
\text { (em massa) }\end{array}$} & \multicolumn{6}{|c|}{ Consumo $\left(\mathrm{kg} / \mathrm{m}^{3}\right)$} \\
\hline & & M1 & M2 & M3 & M4 & M5 & M6 \\
\hline Cimento & 1 & 874 & 869 & 865 & 856 & 848 & 839 \\
\hline Areia & 1,101 & 962 & 957 & 952 & 943 & 933 & 924 \\
\hline Sílica Ativa & 0,235 & 215 & 214 & 213 & 211 & 209 & 206 \\
\hline Pó de Quartzo & 0,246 & 205 & 204 & 203 & 201 & 199 & 197 \\
\hline Superplastificante (3\%) & 0,030 & 26 & 26 & 26 & 26 & 25 & 25 \\
\hline Água $(\mathrm{a} / \mathrm{c}=0,18)$ & 0,180 & 157 & 157 & 156 & 154 & 153 & 151 \\
\hline Fibras & -- & 0 & 38 & 75 & 150 & 225 & 300 \\
\hline
\end{tabular}

Na mistura utilizou-se água de amassamento resfriada e após a moldagem, os modelos eram levados à câmara úmida, onde permaneceram por 48 horas, em seguida, eram submetidos a cura térmica a temperatura de $80^{\circ} \mathrm{C}$ por período de 24 horas, e por fim eram levados novamente para câmara úmida, onde permaneciam até a data do ensaio.

\section{5- Moldagem, Adensamento e Cura dos Modelos}

Para cada série eram necessários 18 fôrmas cilíndricas e 3 prismáticos, conforme previsto no programa experimental da tabela 4.1. No entanto, para substituir alguns modelos que por ventura apresentassem problemas de moldagem, preparavam-se mais 6 corpos-de-prova cilíndricos, resultando para cada série, 24 modelos cilíndricos e 3 prismáticos. Com isso, o volume de concreto por série era calculado considerando o volume de todos os modelos, e margem de $10 \%$ de perdas, totalizando $0,008 \mathrm{~m}^{3}$. 
Para cada série utilizaram-se as dosagens da tabela 4.2, para determinar a quantidade de cada material que compuseram os concretos de pós reativos desenvolvidos. Em seguida, esses materiais eram misturados, lançados, adensados e curados, com procedimentos desenvolvidos especialmente para esta pesquisa.

\subsection{1- Mistura dos materiais}

A mistura dos materiais nas proporções indicadas, iniciava-se com a pré mistura de todos os materiais secos, os quais eram colocados em um saco plástico e agitados manualmente, figura 4.22 , até que se alcançasse boa homogeneidade.
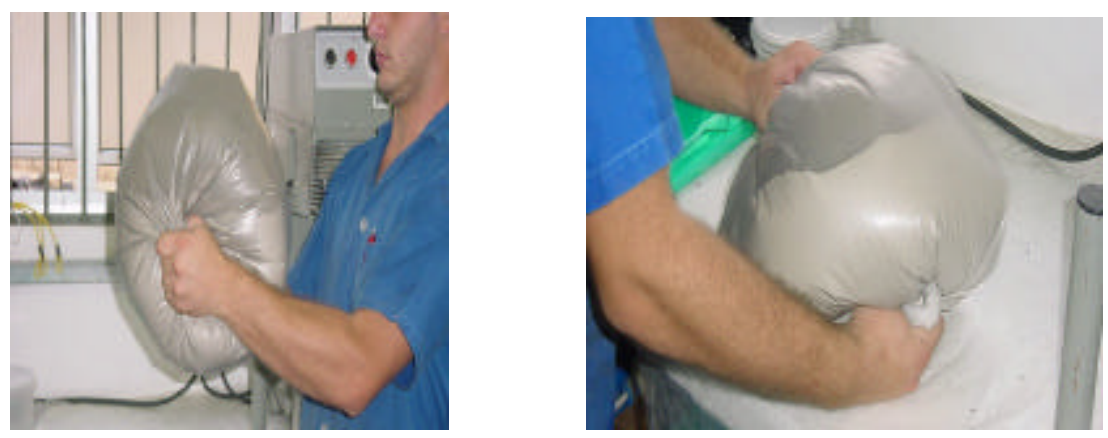

Figura 4.22- Pré mistura dos materiais secos.

Em seguida, a pré mistura era colocada no misturador mecânico planetário do Laboratório de Materiais Avançados a Base de Cimento Portland da EESC - USP, onde prosseguia-se com a homogeneização dos materiais secos por alguns minutos, figura 4.23 .

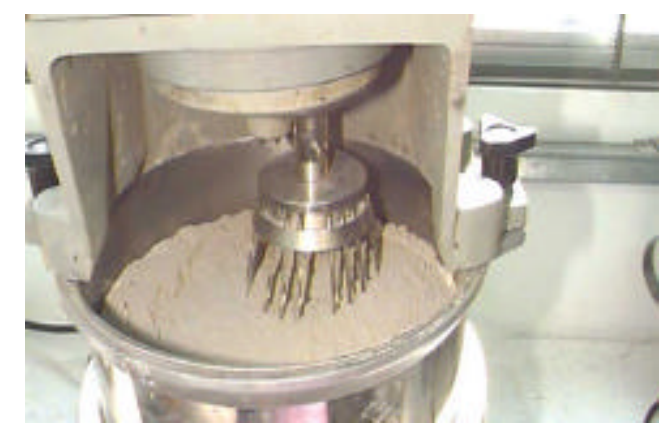

Figura 4.23- Mistura mecânica dos materiais secos.

A água de amassamento era misturada com o superplastificante formando uma solução única, a qual era adicionada em pequenas doses na mistura dos pós, com o misturador em alta velocidade, por aproximadamente 2 minutos. Em seguida, diminuía-se a velocidade de rotação do misturador e aguardava-se até que a mistura atingisse a consistência esperada, figuras 4.24 e 4.25 . 


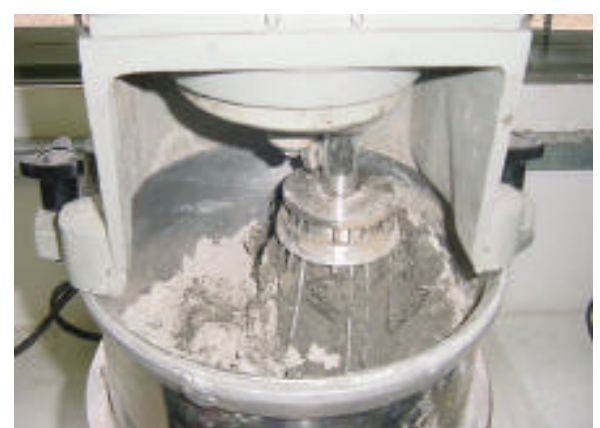

Figura 4.24- Adição da água e superplastificante na pré mistura.

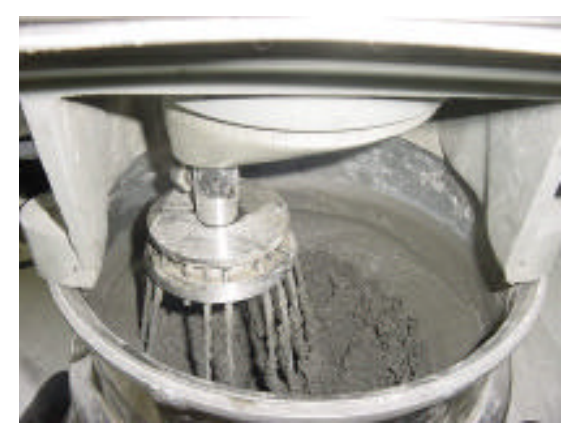

Figura 4.25- Consistência desejada para a mistura final.

Os modelos das séries M2 até M6 continham fibras metálicas, que eram adicionadas a mistura depois desta atingir a consistência desejada, conforme mostrado na figura 4.26 .
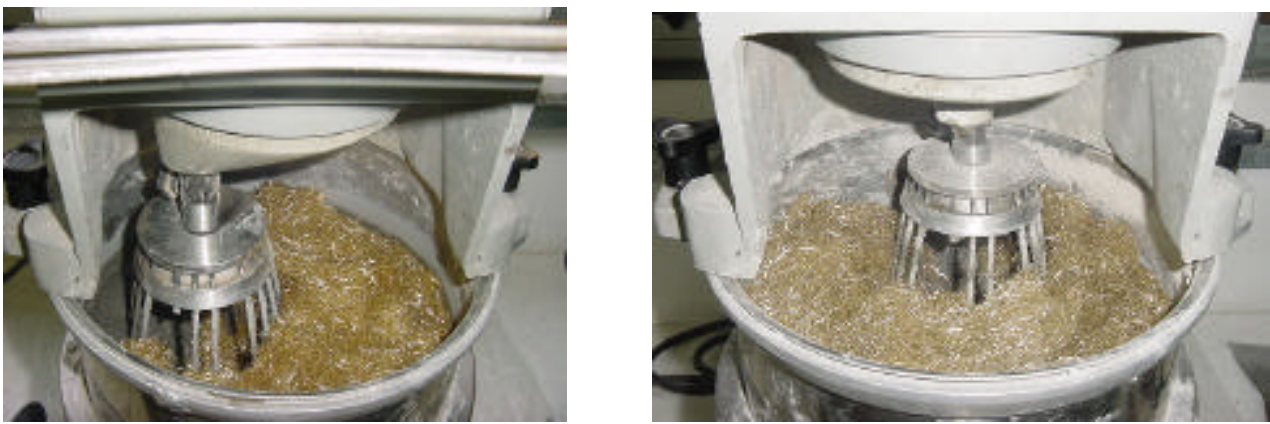

Figura 4.26- Adição das fibras metálicas na mistura.

Depois de adicionadas as fibras metálicas, a velocidade do misturador era aumentada, e aguardava-se por aproximadamente 3 minutos, ou até que a mistura apresentasse a consistência desejada, como mostrado na figura 4.27.
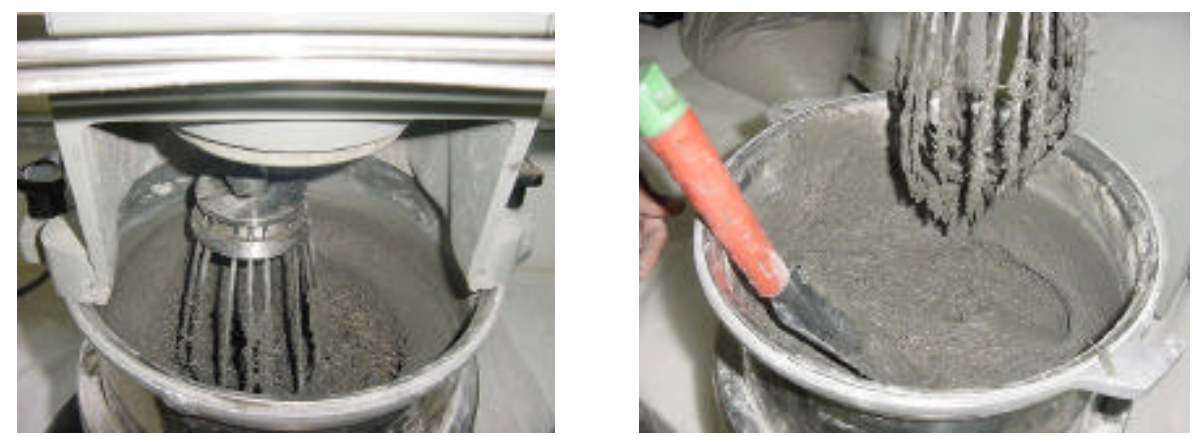

Figura 4.27- Mistura com fibras metálicas pronta para moldagem dos modelos.

\subsection{2- Moldagem dos modelos}

Com a mistura pronta, iniciava-se a moldagem dos modelos. Para isso utilizouse uma bisnaga plástica, semelhante ao "saco de confeiteiro", para auxiliar na moldagem. A bisnaga era preenchida com a mistura conforme mostra a figura 4.28. 

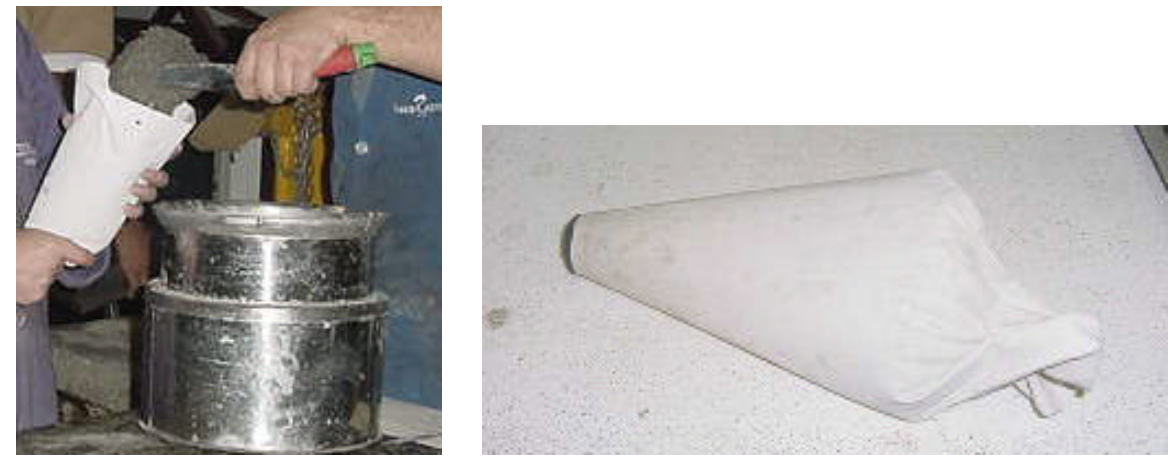

Figura 4.28- Bisnaga utilizada para auxiliar na moldagem dos modelos.

A moldagem dos modelos era feita sobre mesa vibratória, onde, com o auxílio da bisnaga, injetava-se concreto na fôrma de maneira lenta, permitindo o adensamento do material. As figuras 4.29 e 4.30 mostram a moldagem dos modelos cilíndricos e prismáticos.
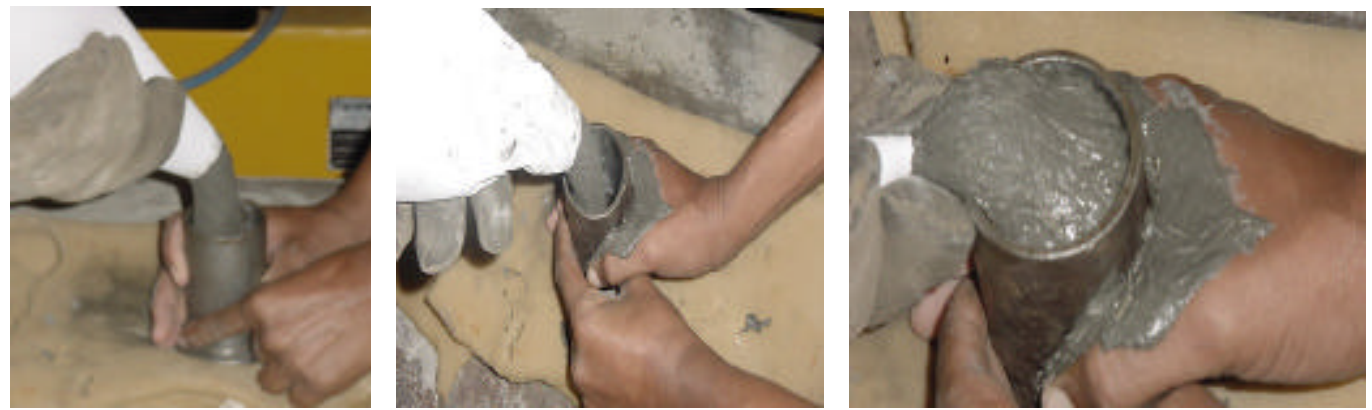

Figura 4.29- Moldagem dos modelos cilíndricos.
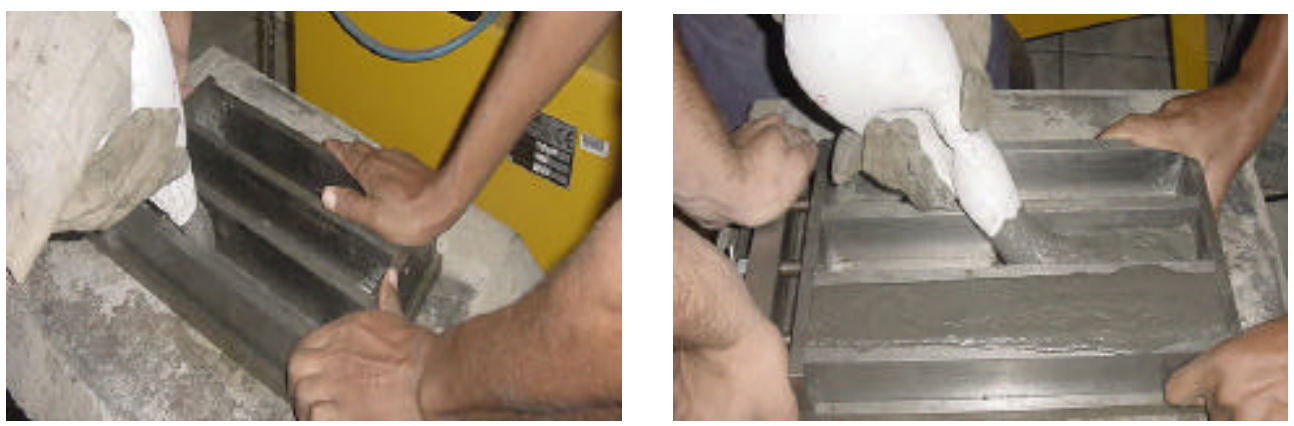

Figura 4.30- Moldagem dos modelos prismáticos.

A bisnaga funcionava como pré adensamento, pois, quando pressionada para injeção do concreto na fôrma, esta exercia pequena pressão na mistura que provocava diminuição da quantidade de ar incorporado e vazios no concreto, melhorando seu adensamento.

Encerrado o preenchimento das fôrmas com o concreto, iniciava-se o acabamento da superfície dos modelos exposta ao ar. Este acabamento tinha como finalidade tornar a superfície exposta o mais plana e lisa possível, e era executado 
com espátula, conforme mostra a figura 4.31. Para os modelos com maior quantidade de fibras, a dificuldade para executar o acabamento era maior.
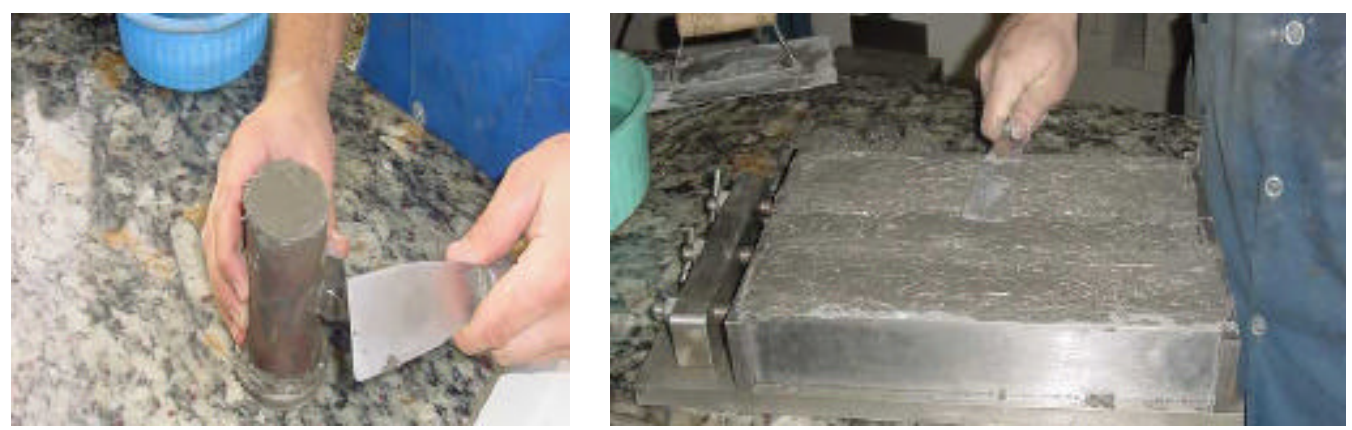

Figura 4.31- Acabamento da superfície exposta ao ar.

\subsection{3- Cura dos modelos}

Após a moldagem e acabamento dos modelos, a superfície exposta ao ar era coberta com filme de PVC fixado com liga de borracha, para evitar o perda de água para o meio ambiente, figura 4.32.
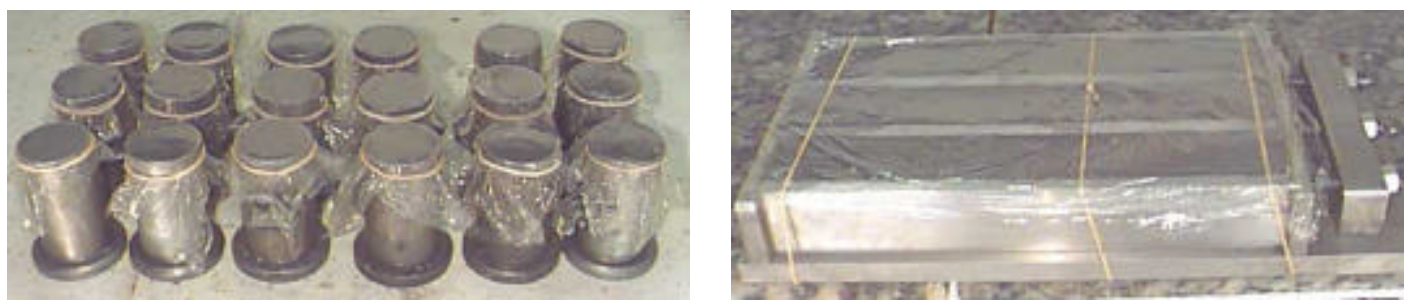

Figura 4.32- Filme de PVC colocado sobre a superfície exposta dos modelos.

Em seguida, os modelos eram levados, ainda nas fôrmas, para câmara úmida do Laboratório de Materiais Avançados a Base de Cimento da EESC - USP, onde aguardavam cerca de 24 horas para a retirada das fôrmas, mas ainda permaneciam na câmara úmida até o instante do início da cura térmica, figuras 4.33 e 4.34.

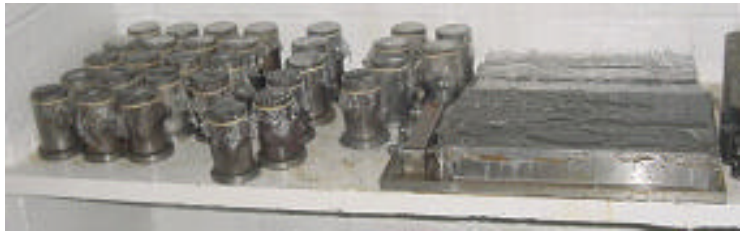

Figura 4.33- Modelos na câmara úmida nas primeiras 24 horas.

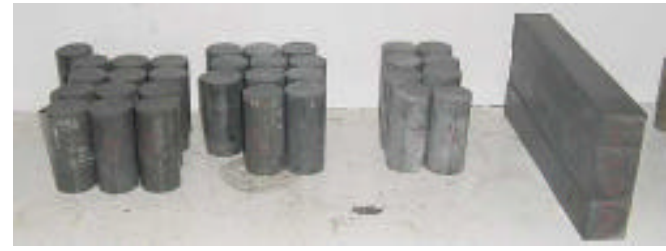

Figura 4.34- Modelos na câmara úmida depois de retirados das fôrmas.

A cura térmica era aplicada 48 horas após o início da hidratação do cimento, conforme estudo descrito no item 3.4.5. Os modelos eram submersos em água, a qual era aquecida gradualmente até atingir a temperatura de $80^{\circ} \mathrm{C}$, e mantida constante por 
20 horas, em seguida resfriava-se a água até a temperatura ambiente. $O$ tempo corresponde ao período entre o início do aquecimento até o fim do resfriamento da água era de 24 horas, conforme determinado no item 3.4.6.

Para realizar a cura térmica, utilizou-se equipamento com controle digital de temperatura do Laboratório de Materiais Avançados a Base de Cimento Portland da EESC - USP, figura 4.35. Com o passar do tempo, a água aquecida evaporava necessitando, assim, de reposição, que era feita com água pré aquecida, a fim de evitar choques térmicos nos modelos.

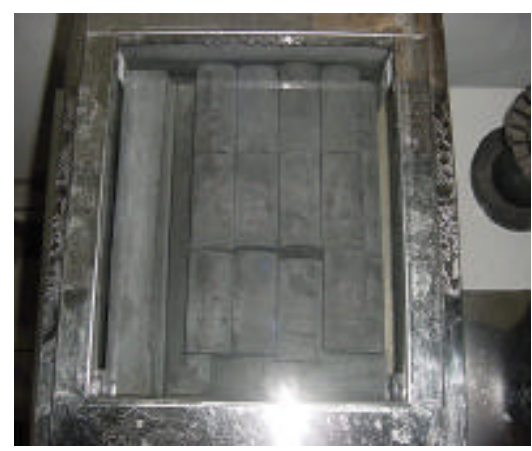

Figura 4.35- Modelos submetidos a cura térmica em equipamento "Banho Maria".

Após a cura térmica, os modelos eram levados novamente para a câmara úmida, onde permaneciam até a idade de 14 dias, exceto os modelos ensaiados aos 7 dias, que eram retirados para serem ensaiados. Passados 14 dias de idade, os modelos eram colocados ao ambiente do laboratório, onde permaneciam até as datas dos ensaios, figura 4.36 .

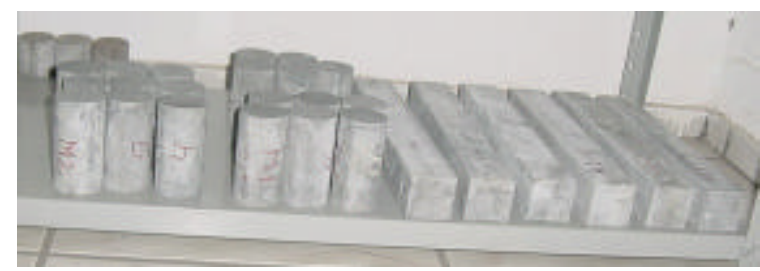

Figura 4.36- Modelos com mais de 14 dias retirados da câmara úmida.

\subsection{4- Preparo das superfícies dos corpos-de-prova}

A superfície dos corpos-de-prova cilíndricos submetidas a acabamento manual após a moldagem, apresentaram irregularidade. Como esses corpos-de-prova eram utilizados nos ensaios de compressão axial, a aplicação da força ocorria nesta região, e por causa da irregularidade, o resultado do ensaio poderia ser comprometido por concentrações de tensões em pontos mais elevados. 
A maneira mais comum de evitar este problema seria a aplicação de uma camada de enxofre na base e no topo desses modelos, tornando assim, estas superfícies paralelas e planas. No entanto, por causa da intensidade de tensão que o concreto de pós reativos resiste, o enxofre seria ineficiente.

Assim, para tornar as superfícies da base e do topo dos modelos paralelas e planas, utilizou-se retífica mecânica com suporte adaptado, do Departamento de Geotecnia da EESC - USP, para realizar este serviço, conforme pode-se observar na figura 4.37 .

Os modelos prismáticos eram ensaiados a flexão em 4 pontos, onde não se utilizava a superfície irregular para aplicação do carregamento e contato com os apoios.
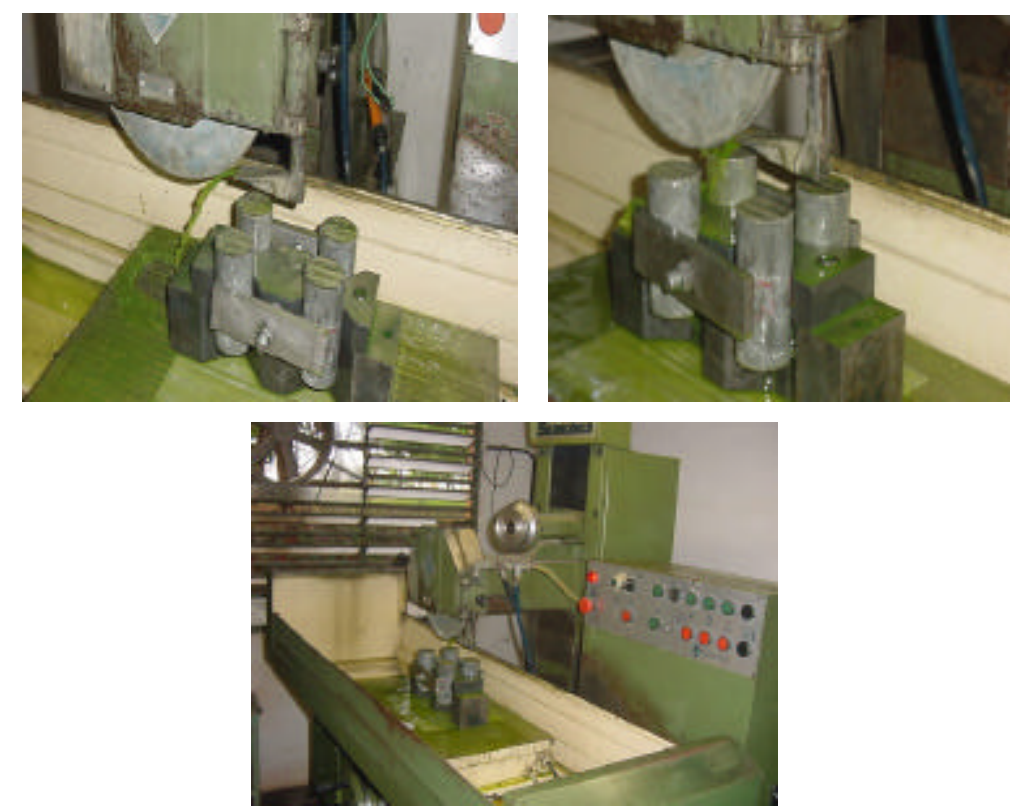

Figura 4.37- Planificação do topo e base dos modelos cilíndricos em retífica mecânica.

\section{6- Descrição dos Ensaios Realizados}

Os ensaios realizados neste estudo foram: compressão axial, para determinar a resistência à compressão nas idades de 7, 14, 28, 63 e 91 dias; compressão axial com controle de deslocamento, para medir o módulo de deformação longitudinal e o comportamento tensão x deformação; e flexão de prismas a 4 pontos, para medir a resistência à tração na flexão e as deformações de tração e compressão na seção submetida a flexão pura. Estes ensaios foram executados de acordo com o programa experimental da tabela 4.1, que previa seis séries com taxas de fibras diferentes.

Cada série era composta por 18 corpos-de-prova cilíndricos de $50 \mathrm{~mm} \times$ $100 \mathrm{~mm}$, e 3 modelos prismáticos de $50 \mathrm{~mm} \times 50 \mathrm{~mm} \times 340 \mathrm{~mm}(\mathrm{~b} \times \mathrm{h} \times \ell)$. Os corpos- 
de-prova cilíndricos eram ensaiados a compressão axial e os prismáticos a flexão em 4 pontos, e a sequência dos ensaios para cada série está exposta na tabela 4.3.

Tabela 4.3- Programa experimental para cada série

\begin{tabular}{|c|c|c|c|}
\hline Estudo & Modelos & $\begin{array}{r}\text { Idade } \\
\text { (dias) }\end{array}$ & Ensaios \\
\hline \multirow{15}{*}{$\begin{array}{l}\text { Resistência à } \\
\text { compressão ao longo } \\
\text { do tempo }\end{array}$} & 1 & 7 & Compressão Axial \\
\hline & 2 & 7 & Compressão Axial \\
\hline & 3 & 7 & Compressão Axial \\
\hline & 4 & 14 & Compressão Axial \\
\hline & 5 & 14 & Compressão Axial \\
\hline & 6 & 14 & Compressão Axial \\
\hline & 7 & 28 & Compressão Axial \\
\hline & 8 & 28 & Compressão Axial \\
\hline & 9 & 28 & Compressão Axial \\
\hline & 10 & 63 & Compressão Axial \\
\hline & 11 & 63 & Compressão Axial \\
\hline & 12 & 63 & Compressão Axial \\
\hline & 13 & 91 & Compressão Axial \\
\hline & 14 & 91 & Compressão Axial \\
\hline & 15 & 91 & Compressão Axial \\
\hline \multirow{3}{*}{$\begin{array}{l}\text { Módulo de elasticidade e } \\
\text { relação tensão } x \\
\text { deformação }\end{array}$} & 16 & 28 & Compressão Axial com controle de deslocamento \\
\hline & 17 & 28 & Compressão Axial com controle de deslocamento \\
\hline & 18 & 28 & Compressão Axial com controle de deslocamento \\
\hline \multirow{3}{*}{$\begin{array}{l}\text { Resistência à tração } \\
\text { na flexão e relação } \\
\text { força x deslocamento }\end{array}$} & M1 & 28 & Flexão em 4 pontos com controle de deslocamento \\
\hline & M2 & 28 & Flexão em 4 pontos com controle de deslocamento \\
\hline & M3 & 28 & Flexão em 4 pontos com controle de deslocamento \\
\hline
\end{tabular}

\subsection{1- Ensaios de compressão axial com controle de força}

Os ensaios de compressão axial eram executados com aplicação da força centrada no topo e na base dos modelos, a uma taxa de 0,5kN/seg.

A análise da resistência à compressão ao longo do tempo era feita para cada série, nas idade de 7, 14, 28, 63 e 91 dias, e tinha como diferença a quantidade de fibras metálicas variando da seguinte maneira: 0\%, 0,5\%, 1\%, 2\%, 3\% e 4\%.

Para cada idade eram ensaiados àcompressão 3 corpos-de-prova idênticos, e a resistência de ruptura era adotada como as médias desses três valores.

\section{a) Ensaios da série M1}

Os corpos-de-prova da série $M 1$, que não continham fibras metálicas, apresentaram comportamento frágil e desintegravam-se quando atingia a ruptura.

As resistências de ruptura à compressão apresentaram comportamento crescente com a idade, partindo de valores médios de 100MPa aos 7 dias, e alcançando 187MPa aos 28 dias. A partir dos 28 dias de idade, os modelos da série M1 apresentaram pequena queda na resistência à compressão, seguida de estabilidade até os 91 dias. 


\section{b) Ensaios da série M2}

Os corpos-de-prova da série $\mathrm{M} 2$, com $0,5 \%$ do seu volume em fibras metálicas, apresentou comportamento frágil, porém menos frágil que o da série $M 1$, quando atingia a ruptura.

Apesar da pequena quantidade de fibras que esta série continha, a resistência à compressão aos 7 dias de idade atingiu 188MPa, apresentando considerável aumento quando comparado com o valor atingido pela série M1. Aos 28 dias, a resistência à compressão apresentou tendência de estabilidade até os 91 dias em torno de 200MPa.

\section{c) Ensaios da série M3}

Os corpos-de-prova da série M3 continham 1\% do seu volume em fibras metálicas, e apresentaram comportamento frágil, porém, sem desintegração quando atingia a ruptura.

Esses modelos alcançaram resistência à compressão aos 7 dias de 193MPa, permanecendo praticamente estável até os 91 dias de idade, onde o valor foi de 190MPa.

\section{d) Ensaios da série M4}

Com $2 \%$ do volume em fibra metálicas, os corpos-de-prova da série M4 apresentaram na ruptura comportamento menos frágil se comparados com os das séries anteriores. Aos 7 dias a resistência à compressão para esta série ficou em $181 \mathrm{MPa}$, crescendo para 200MPa aos 28 dias.

Entre o $28^{\circ}$ e $063^{\circ}$ dia, a resistência à compressão permaneceu estável em 200MPa, no entanto, aos 91 dias os modelos registraram resistência à compressão média de $210 \mathrm{MPa}$.

\section{e) Ensaios da série M5}

Para a série $\mathrm{M} 5$, os corpos-de-prova continha $3 \%$ do volume em fibras metálicas, provocando maior dificuldade de mistura, moldagem e adensamento. $O$ excesso de fibras provocou também perda de trabalhabilidade com o tempo, necessitando de constante agitação da mistura durante a moldagem das fôrmas.

Esta série atingiu resistência à compressão aos 7 dias de $210 \mathrm{MPa}$, o que foi considerado valor elevado quando comparado com os modelos das outras séries com a mesma idade. Aos 28 dias, a resistência sofreu pequenos decréscimo, regredindo para 204MPa, mas a partir de então, voltou a aumentar atingindo aos 91 dias o valor de $213 \mathrm{MPa}$. 


\section{f) Ensaios da série M6}

Os corpos-de-prova da série M6 foram feitos com taxa de fibras metálicas de $4 \%$ do volume. Para esta quantidade de fibra, percebeu-se grande perda de trabalhabilidade e dificuldades de moldagem e adensamento.

A resistência àcompressão para os corpos-de-prova desta série foi de $200 \mathrm{MPa}$ aos 7 dias, 204MPa aos 28 dias e 210MPa com 91 dias, ou seja, apresentou pouca variação na resistência.

\subsection{2- Ensaios de compressão axial com controle de deslocamento}

Os ensaios de compressão axial com controle de deslocamento foram realizados em equipamento servocontrolado, figura 4.38, onde a aplicação da força era feita com o êmbolo do atuador hidráulico, deslocando-se com velocidade controlada.
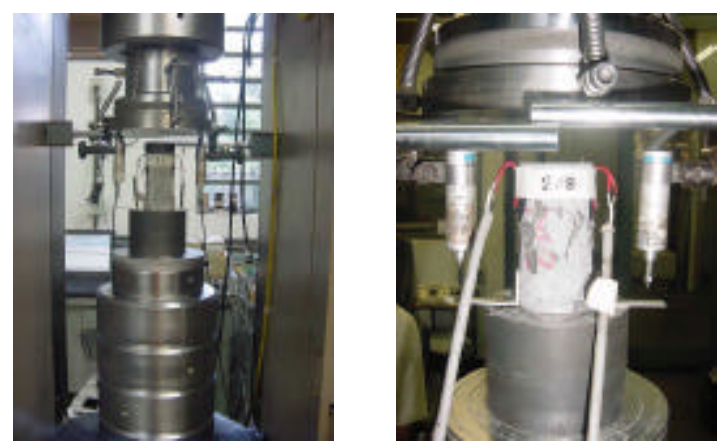

Figura 4.38- Ensaio de compressão axial.

Os corpos-de-prova de cada série eram ensaiados com idade de 28 dias, e tinha como diferencial a quantidade de fibras metálicas variando da seguinte maneira: $0 \%, 0,5 \%, 1 \%, 2 \%, 3 \%$ e $4 \%$. Para cada idade eram ensaiados à compressão 3 modelos idênticos.

Antes de iniciar o ensaio, o corpo-de-prova era submetido a uma força de $50 \mathrm{kN}$ aplicada com velocidade de $0,5 \mathrm{kN} / \mathrm{s}$, e em seguida descarregado até a força de $0,1 \mathrm{kN}$, ficando os modelos pré-carregados para o início do ensaio. Esse pré-carregamento era desconsiderado, pois os equipamentos eram zerados a partir deste instante. Tal procedimento era realizado com a finalidade de acomodar o sistema de apoios e aplicação de força, evitando interferência de eventuais deslocamentos provenientes destes, assim como, acomodar a estrutura interna do concreto e testar os equipamentos de medições.

O ensaio de compressão axial era feito em duas etapas, e a diferença entre estas, era apenas a velocidade de deslocamento do êmbolo do atuador. A primeira etapa consistia em aplicar força até $70 \%$ da força máxima prevista para cada série, e a 
taxa de deslocamento aplicada era de $1,17 \mu \mathrm{m} / \mathrm{s}$, o que correspondia, em taxa de força, a aproximadamente $0,6 \mathrm{kN} / \mathrm{s}$. Na segunda etapa, diminuía-se a velocidade de deslocamento do êmbolo do atuador para $0,33 \mu \mathrm{m} / \mathrm{s}$, correspondendo a taxa de força de aproximadamente $0,16 \mathrm{kN} / \mathrm{s}$, prosseguindo com o ensaio até o final. Não havia pausa no ensaio entre a primeira e a segunda etapa, o equipamento alterava a velocidade automaticamente conforme programado.

A força máxima prevista para cada série era determinada de acordo com os resultados dos ensaios de compressão axial sem controle de deslocamento, que era realizado pouco antes.

Adotou-se mudança de velocidade de carregamento durante o ensaio, por causa da fragilidade que os corpos-de-prova com pouca quantidade de fibras metálicas apresentavam. Assim, próximo da ruptura, diminuía-se a velocidade de deslocamento do êmbolo do atuador, a fim de evitar ruptura brusca e também na tentativa de obter dados sobre o comportamento pós ruptura do concreto de pós reativos.

$\mathrm{Na}$ primeira etapa do carregamento, utilizou-se velocidade de carregamento maior que na segunda etapa, pois sabia-se que o material permanecia no regime elástico até aproximadamente $70 \%$ da força última. Com isso, adotou-se velocidade de deslocamento do êmbolo que correspondesse a taxa de força próxima daquela utilizada nos ensaios de compressão axial sem controle de deslocamento, que era de 0,5kN/s, na intenção de poder comparar os ensaios feitos em equipamentos diferentes. As formas de rupturas dos corpos-de-prova dependiam das quantidades de fibras que cada série continha, conforme mostra a figura 4.39 .

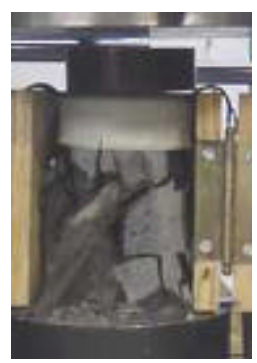

M1

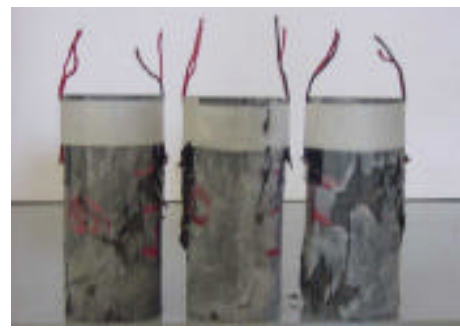

M4

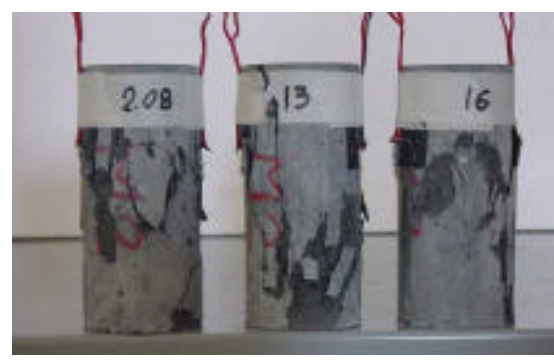

M2

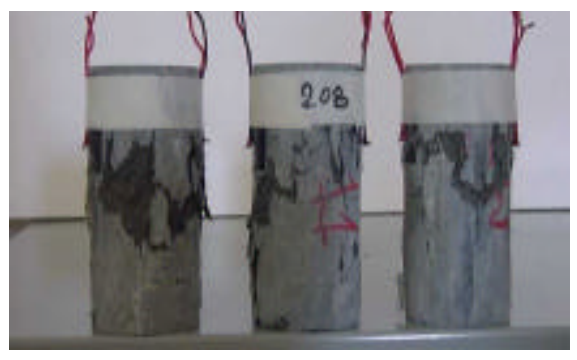

M3

Figura 4.39- Forma de ruptura dos modelos comprimidos.

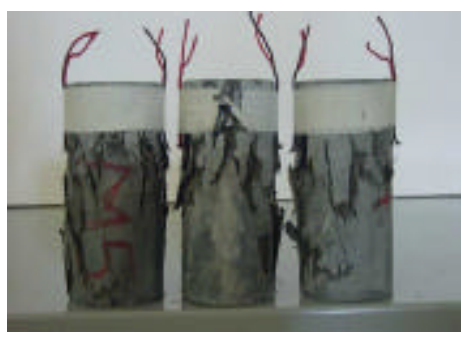

M5

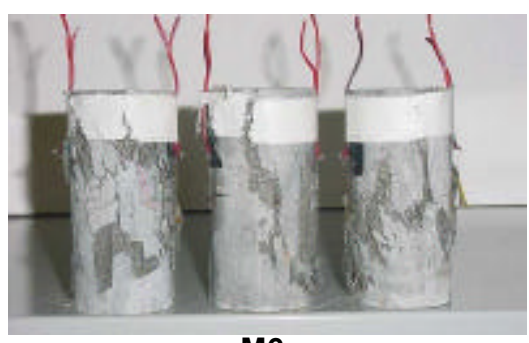

M6 


\subsection{3- Ensaios de flexão a 4 pontos com controle de deslocamento}

Os ensaios de flexão a 4 pontos também foram realizados com controle de deslocamento em equipamento servocontrolado, figura 4.40. Para cada série eram ensaiados 3 modelos idênticos com idade de 28 dias, e tinha como diferencial a quantidade de fibras metálicas.
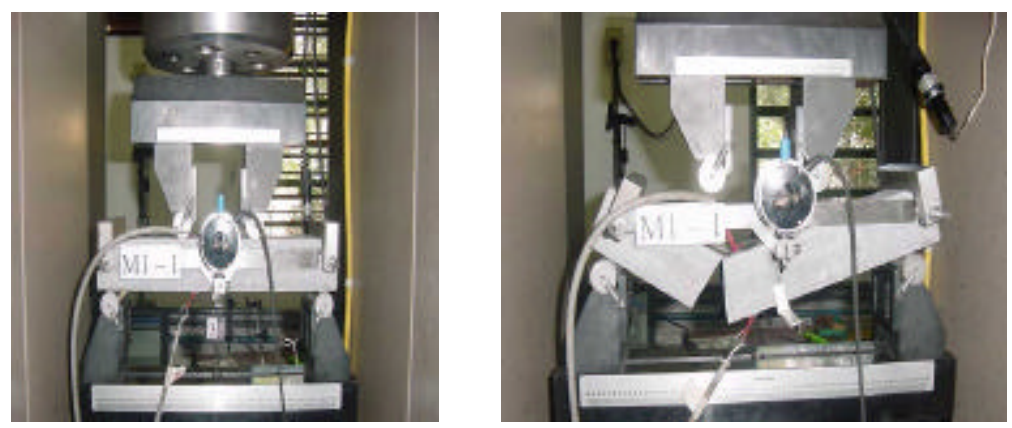

Figura 4.40- Ensaio de flexão a 4 pontos

Os ensaios foram feitos em duas etapas, com diferentes velocidades de deslocamento do êmbolo do atuador. A primeira etapa consistia em aplicar força até que surgissem as primeiras fissuras, e a força apresentasse tendência de queda ou estabilidade, nesta fase a taxa de deslocamento aplicada era de $0,33 \mu \mathrm{m} / \mathrm{s}$. A segunda etapa era continuação da primeira, com velocidade de deslocamento aumentada para $1,33 \mu \mathrm{m} / \mathrm{s}$, prosseguindo com o ensaio até o final. A mudança de velocidade entre a primeira e a segunda etapa era feita de modo automático pelo equipamento, conforme programado.

Adotou-se aumento de velocidade de carregamento a partir de determinado instante do ensaio, pois após atingir a força máxima, os modelos continuavam a se deformarem por longo período de tempo até sua conclusão, tornando o ensaio muito demorado.

\subsubsection{1- Ensaios da série M1}

A série $M 1$ era composta de 3 modelos iguais (M1-1, M1-2, M1-3) que não continham fibras metálicas em sua composição. Para os modelos desta série, ocorreram problemas no registro do deslocamento vertical da seção transversal, pois o concreto de pós reativo se mostrou como um material muito frágil, que ao aparecimento das primeiras microfissuras, os modelos rompiam de forma brusca.

Por causa dos problemas ocorridos no preparo do ensaio, o modelo M1-2 foi danificado, chegando a romper no instante dos ajustes para aplicar a força. Este fato 
serviu para mostrar a grande fragilidade do material, quando não utilizado fibras em sua composição.

As rupturas dos modelos da série M1 ocorreram de forma frágil, por meio de uma única fissura que surgia no terço central dos modelos, conforme pode-se observar na figura 4.41. A resistência à tração na flexão foi adotada como sendo o valor médio dos resultados obtidos em cada modelo ensaiado. Para a série M1, esta tensão foi de 11,83MPa.

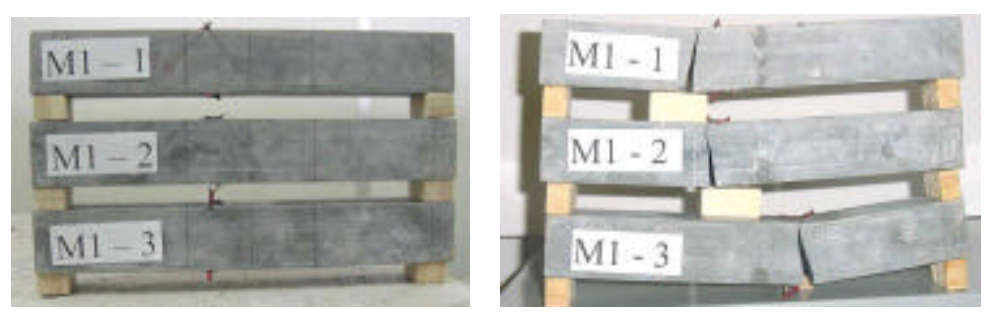

Figura 4.41- Forma de ruptura dos modelos da série M1

\subsubsection{2- Ensaios da série M2}

Os três modelos (M2-1, M2-2, M2-3) da série M2 continham 0,5\% do seu volume de fibras metálicas.

Durante os ensaios, observou-se que os modelos apresentaram grande rigidez, com deslocamentos verticais praticamente nulos, semelhante ao comportamento da série $\mathrm{M1}$, até o instante que surgiu a primeira fissura. A partir deste instante, os modelos começavam apresentar deformações sem atingirem o colapso, o que pode ser atribuído a pequena quantidade de fibras que estes continham.

As rupturas dos modelos da série M2 ocorreram de forma dúctil, no entanto, com aparecimento de apenas uma ou duas fissuras principais, que surgiam no terço central dos modelos, conforme pode-se observar na figura 4.42. A resistência àtração na flexão para a série M2 foi de 13,82MPa.
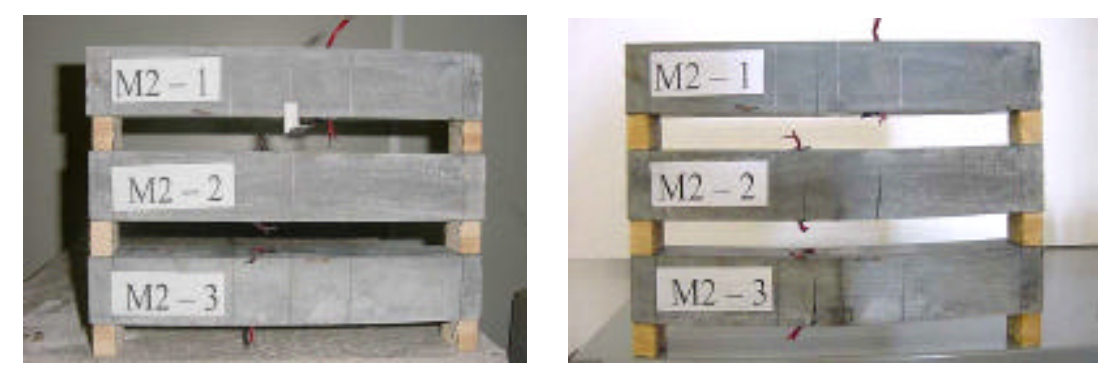

Figura 4.42- Forma de ruptura dos modelos da série M2 


\subsubsection{3- Ensaios da série M3}

Os modelos M3-1, M3-2, M3-3 da série M3, com 1\% do seu volume em fibras metálicas, apresentaram deslocamentos verticais praticamente nulos no início do ensaio, semelhante ao comportamento da série M1. Porém, ainda com intensidade de força baixa, a seção central apresentou deslocamento vertical sem atingir o colapso, ou seja, o material com $1 \%$ de fibras mostrou-se mais deformável mesmo quando submetido a baixas tensões.

As rupturas dos modelos da série M3 ocorreram de forma dúctil, com aparecimento de fissuras na região central dos modelos, conforme pode-se observar na figura 4.43. A tensão de tração na flexão para esta série foi de 20,82MPa.
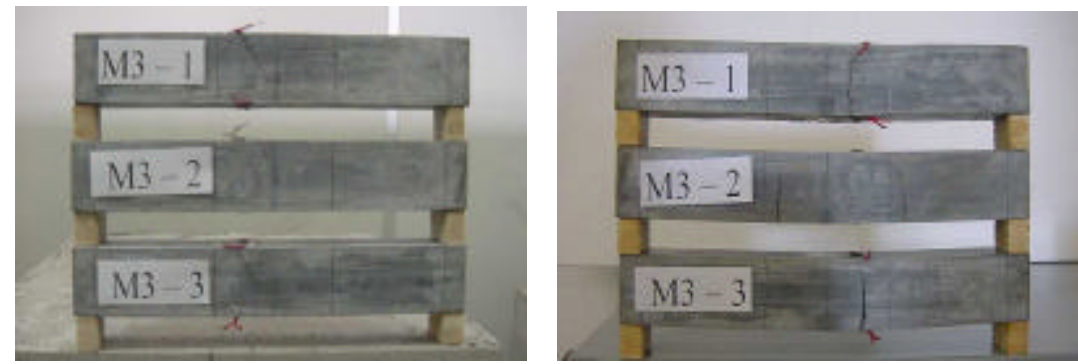

Figura 4.43- Forma de ruptura dos modelos da série M3

\subsubsection{4- Ensaios da série M4}

A série M4 (M4-1, M4-2, M4-3), foi moldada com $2 \%$ do volume em fibras, apresentando deslocamentos desde o início do ensaio.

As rupturas desses modelos ocorreram de forma dúctil, com aparecimento de fissuras principais no terço central dos modelos, conforme pode-se observar na figura 4.44. A resistência àtração na flexão para esta série foi de $28,07 \mathrm{MPa}$.
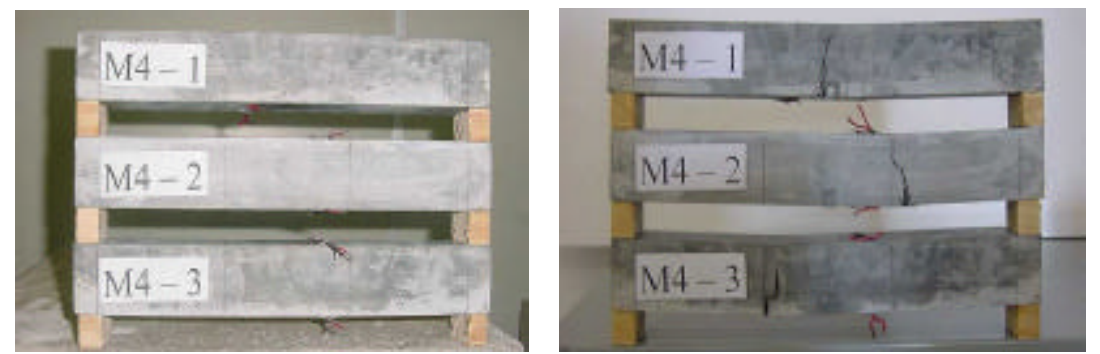

Figura 4.44- Forma de ruptura dos modelos da série M4

\subsubsection{5- Ensaios da série M5}

O comportamento dos modelos da série M5 (M5-1, M5-2, M5-3), que continham $3 \%$ do volume em fibras, foi semelhante aos da série M4. 
A ruptura ocorreu de forma dúctil, com aparecimento de fissuras principais no terço central dos modelos, figura 4.45. A tensão de tração na flexão para esta série foi de $29,31 \mathrm{MPa}$.
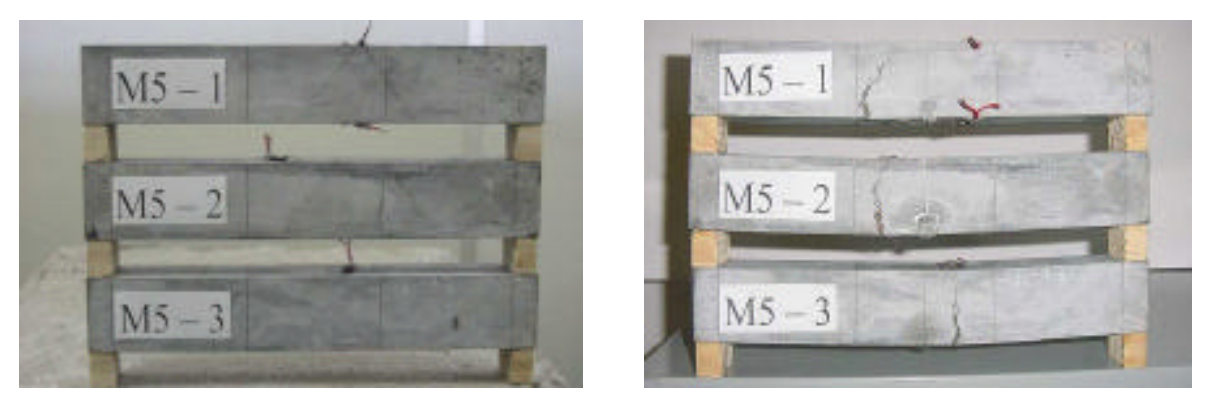

Figura 4.45- Forma de ruptura dos modelos da série M5

\subsubsection{6- Ensaios da série M6}

Os modelos da série M6 (M6-1, M6-2, M6-3), com 4\% do volume em fibras, apresentaram comportamento semelhante aos das séries M4 e M5.

Os ensaios apresentaram ruptura dúctil, com aparecimento de fissuras bem ao centro dos modelos, figura 4.46. A resistência àtração na flexão para esta série foi de $34,81 \mathrm{MPa}$.
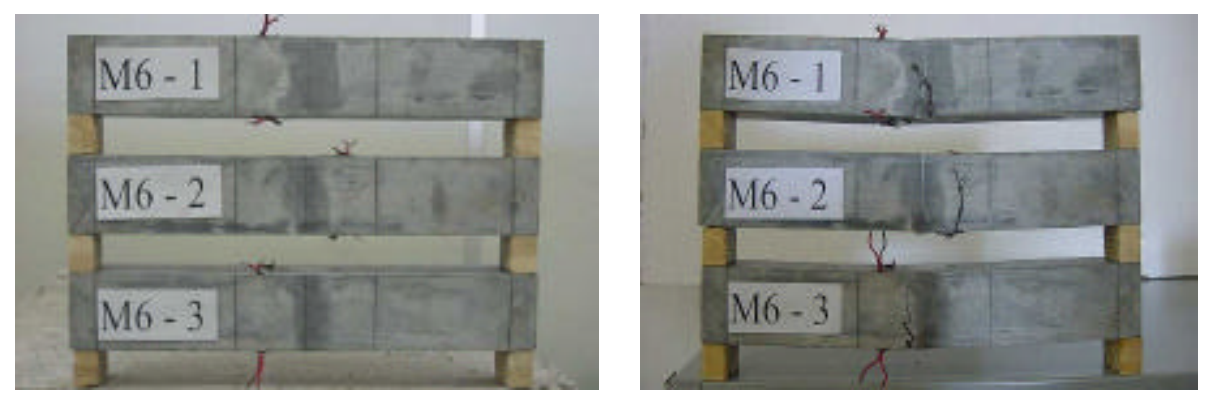

Figura 4.46- Forma de ruptura dos modelos da série M6

\section{Considerações Finais}

Este capítulo mostrou todo o procedimento utilizado para realizar os ensaios dos modelos, como: metodologia e programa experimental, materiais utilizados, detalhes de execução dos ensaios e comportamento dos modelos na ruptura.

Observou-se que foram atingidas resistências à compressão próximos dos 200MPa para a idade de 28 dias, tal como previa o programa experimental.

A resistência àtração na flexão variou com a taxa de fibras utilizada, onde os modelos sem fibras tiveram tensão média de $11,83 \mathrm{MPa}$, e os com $4 \%$ de fibras atingiram tensão média de 34,81MPa. 
Os ensaios àcompressão axial apresentaram ruptura frágil, mesmo com taxas de fibras de 4\%. Já os ensaios àflexão mostraram fragilidade apenas para os modelos sem fibras, as séries com o mínimo de fibras apresentaram grande diferença no comportamento da ruptura, tornando-se cada vez mais dúcteis com o aumento da quantidade de fibras. 


\section{Capítulo}

\section{ANÁLISE DOS RESULTADOS}

\section{Considerações Iniciais}

Neste capítulo, são apresentadas as análises dos resultados dos ensaios de compressão axial e flexão em 4 pontos, realizados em modelos feitos com concreto de pós reativos.

Para os ensaios de compressão axial, foram analisados: o comportamento da resistência à compressão ao longo do tempo; a influência das fibras na resistência à compressão; a relação tensão $x$ deformação para o concreto de pós reativos; 0 módulo de deformação longitudinal; e as deformações específicas na compressão.

Para os ensaios de flexão em 4 pontos, analisou-se: a influência das fibras na resistência à tração na flexão; o comportamento força $x$ deslocamento; e as deformações últimas na tração.

Com as análises, foi proposta uma relação constitutiva para tensões de compressão, que pode ser utilizada para concreto de pós reativos, com resistência à compressão próxima de 200MPa e volume de fibras até $4 \%$. 
O estudo experimental do concreto de pós reativos, baseado no material desenvolvido de acordo com o descrito no capítulo 3, e cuja experimentação foi detalhada no capítulo 4, pretende analisar o comportamento do concreto de pós reativos, quando solicitado a tensões de compressão e tração, a fim de conhecer melhor suas propriedades mecânicas, visando utilização para fins estruturais.

\section{1- Resistência à Compressão}

Em virtude da hidratação das partículas de cimento, que ocorre ao longo do tempo, a resistência àcompressão do concreto aumenta com a idade. Para o concreto de pós reativos, que tem composição diferente dos concretos usuais, a resistência à compressão apresenta comportamento semelhante, principalmente quando não existem fibras na mistura.

De acordo com o mencionado no item 3.4.4, a resistência à compressão do concreto de pós reativos sem fibras, aumenta com o tempo, independente do tipo de cura ou da relação água cimento adotada. Entretanto, quando adicionadas fibras, o concreto passa a atingir resistências maiores aos 7 dias de idade, e a partir desta data o crescimento ocorre de forma mais lenta, conforme foi analisado no item 3.4.8.

Nos ensaios de compressão axial em corpos-de-prova cilíndricos de $50 \mathrm{~mm} x$ $100 \mathrm{~mm}$, com controle da taxa de força aplicada, analisou-se a variação da resistência à compressão do concreto de pós reativos dos 7 até os 91 dias. Essa análise foi realizada em 6 séries com taxas de fibras de 0\%, 0,5\%, 1\%, 2\%, 3\% e 4\% em volume, e cura térmica a temperatura de $80^{\circ} \mathrm{C}$, conforme explicado no item 4.4. Os resultados são mostrados na tabela 5.1 .

Tabela 5.1 - Resistência à compressão em CPR

\begin{tabular}{c|c|r|r|r|r|r}
\hline \multirow{2}{*}{ Séries } & \multirow{2}{*}{ \% } & \multicolumn{5}{|c}{ Resistência à compressão (MPa) } \\
\cline { 3 - 7 } & & 7 dias & 14 dias & 28 dias & 63 dias & 91 dias \\
\hline M1 & $\mathbf{0}$ & 105,65 & 159,60 & 190,70 & 182,00 & 187,50 \\
\hline M2 & $\mathbf{0 , 5}$ & 188,20 & 190,60 & 199,80 & 200,20 & 201,00 \\
\hline M3 & $\mathbf{1}$ & 196,15 & 181,85 & 189,23 & 197,15 & 202,00 \\
\hline M4 & $\mathbf{2}$ & 190,90 & 199,30 & 203,58 & 199,00 & 210,63 \\
\hline M5 & $\mathbf{3}$ & 209,75 & 206,35 & 206,10 & 210,50 & 213,40 \\
\hline M6 & $\mathbf{4}$ & 199,45 & 192,57 & 204,27 & 202,25 & 213,10 \\
\hline
\end{tabular}

\subsection{1- Comportamento da resistência à compressão ao longo do tempo}

De acordo com os resultados da tabela 5.1, pode-se observar que a resistência àcompressão apresenta tendência de crescimento com o tempo, esse comportamento é ilustrado na figura 5.1. Os corpos-de-prova sem fibras apresentaram crescimento na 
resistência até os 28 dias de idade, permanecendo estável a partir desta data. Entretanto, os corpos-de-prova contendo fibras apresentaram comportamento diferente, pois notou-se que a resistência à compressão se estabilizou prematuramente a partir dos 7 dias de idade, onde os modelos atingiram em média 94\% da resistência aos 91 dias. Isso significa que a adição de fibras, juntamente com a cura térmica, promovem aceleração do crescimento da resistência nas primeiras idades.

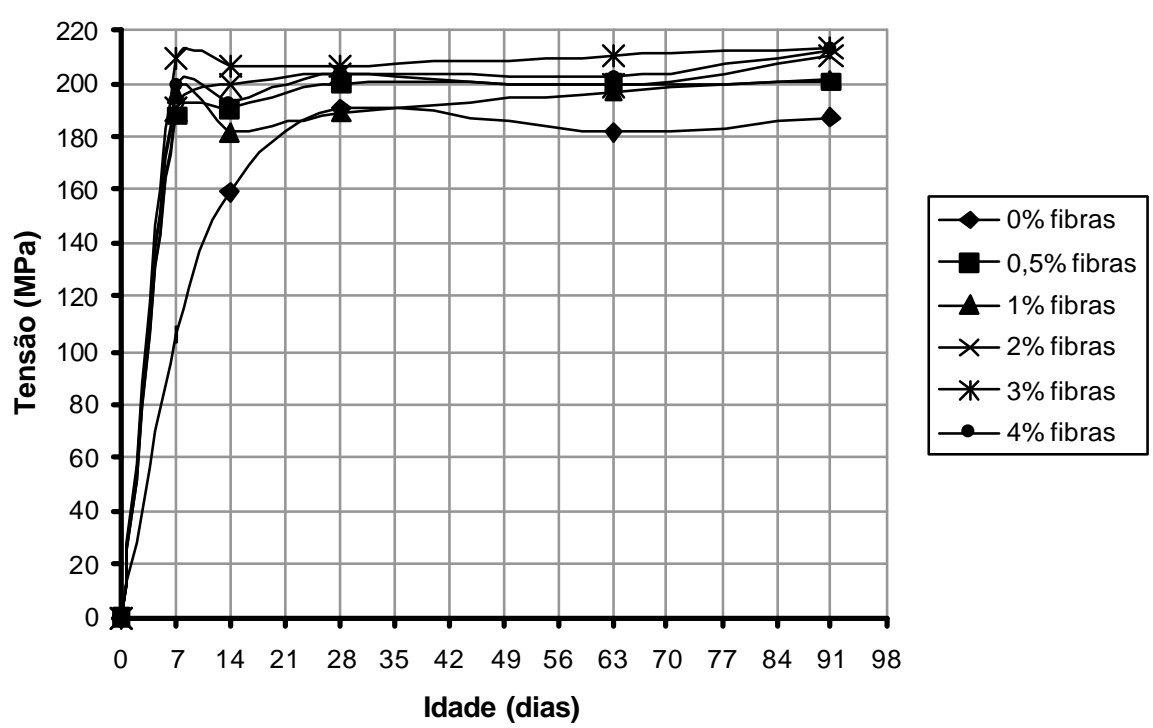

Figura 5.1 - Crescimento da resistência à compressão com o tempo

Como aos 7 dias de idade a resistência àcompressão já era elevada, houve a necessidade de analisar o crescimento da resistência nas primeiras horas de hidratação. Para isso, foram realizados ensaios de compressão axial em modelos cilíndricos de $50 \mathrm{~mm} \times 100 \mathrm{~mm}$, utilizando a dosagem da tabela 4.2, com taxa de fibras de $3 \%$ do volume.

O programa de ensaio foi constituído por duas séries com 36 modelos em cada. Uma série foi submetida a cura úmida, e a outra foi colocada sob cura térmica a temperatura de $80^{\circ} \mathrm{C}$ após 48 horas de idade, conforme procedimentos adotados para os ensaios anteriores.

Os modelos eram ensaiados em intervalos de 12 horas até o quarto dia, e a partir de então, o intervalo era de 24 horas até o sétimo dia. Para cada ensaio, rompiam-se três modelos, e o resultado adotado para aquela idade era a média dos três valores medidos.

Os resultados mostraram que até as 48 horas, as resistências das duas séries foram praticamente iguais, pois ambas estavam submetidas ao mesmo tipo de cura. $\mathrm{Na}$ idade de 60 horas, os modelos da segunda série, que estavam sob cura térmica a 
12 horas, apresentaram grande crescimento na resistência, se comparado com o resultado dos modelos da primeira série na mesma idade.

A tabela 5.2 apresenta os resultados médios das resistências à compressão para todas as idades analisadas, e a figura 5.2 ilustra esses resultados.

Tabela 5.2 - Resistência à compressão nas primeiras horas, com e sem cura térmica

\begin{tabular}{c|c|c}
\hline \multirow{2}{*}{$\begin{array}{c}\text { Idade } \\
\text { (horas) }\end{array}$} & \multicolumn{2}{|c}{ Tensão (MPa) } \\
\cline { 2 - 3 } & Sem cura térmica & Com cura térmica \\
\hline $\mathbf{0}$ & 0,00 & 0,00 \\
\hline $\mathbf{1 2}$ & 35,00 & 36,80 \\
\hline $\mathbf{2 4}$ & 59,85 & 61,07 \\
\hline $\mathbf{3 6}$ & 83,35 & 84,40 \\
\hline $\mathbf{4 8}$ & 96,00 & 98,20 \\
\hline $\mathbf{6 0}$ & 102,85 & 168,10 \\
\hline $\mathbf{7 2}$ & 103,05 & 177,80 \\
\hline $\mathbf{8 4}$ & 104,25 & 180,90 \\
\hline $\mathbf{9 6}$ & 111,70 & 190,10 \\
\hline $\mathbf{1 2 0}$ & 111,95 & 191,00 \\
\hline $\mathbf{1 4 4}$ & 120,55 & 192,80 \\
\hline $\mathbf{1 6 8}$ & 120,00 & 200,50 \\
\hline
\end{tabular}

Desse modo, conclui-se que, mesmo sem cura térmica, este concreto apresenta alta resistência àcompressão com 2 dias de idade; e que a cura térmica foi responsável pela aceleração do crescimento da resistência àcompressão do concreto de pós reativos nos primeiros dias.

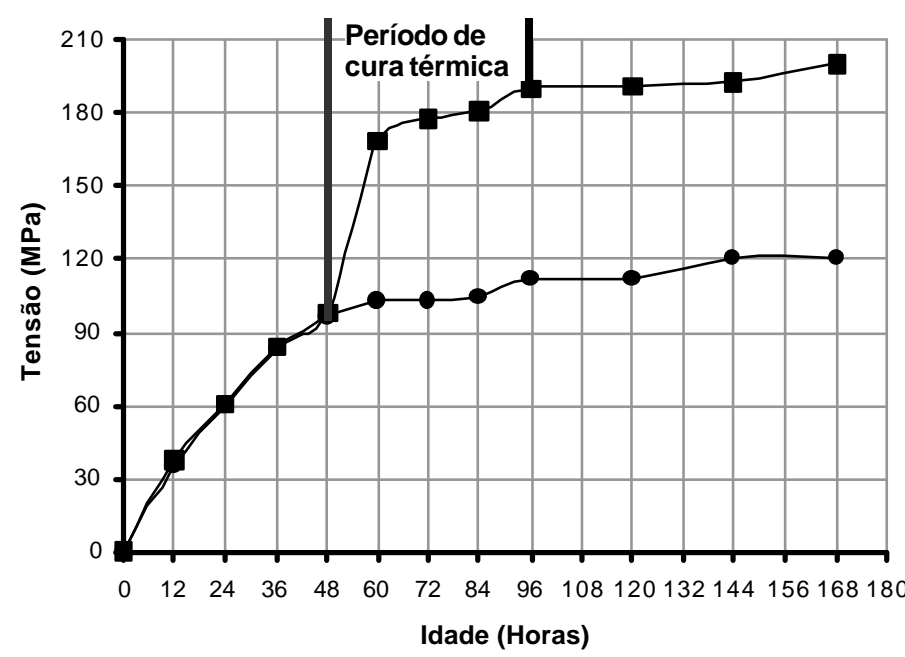

- Sem Cura Térmica -Com Cura Térmica

Figura 5.2 - Crescimento da resistência à compressão do CPR nas primeiras idades 


\subsection{2- Influência das fibras na resistência à compressão}

As fibras metálicas foram utilizadas no concreto de pós reativos, com a intenção de diminuir sua fragilidade, quando ocorrem o aparecimento das primeiras fissuras.

Os resultados dos ensaios expostos na tabela 5.1, foram ilustrados pela figura 5.3, que relaciona a resistência àcompressão com o volume de fibras. Observou-se o mesmo comportamento descrito no item 3.4.8, onde foram realizados ensaios preliminares, em que o aumento do volume de fibras no concreto provocou maior resistência à compressão. Isso foi observado até a taxa de $3 \%$ de fibras, a partir da qual os gráficos apresentaram tendência de queda. A diminuição da resistência a partir de um determinado volume de fibras pode ser justificada pela presença de defeitos nos modelos, por causa de problemas de adensamento, já que a quantidade de fibras era grande, acarretando dificuldades na trabalhabilidade.

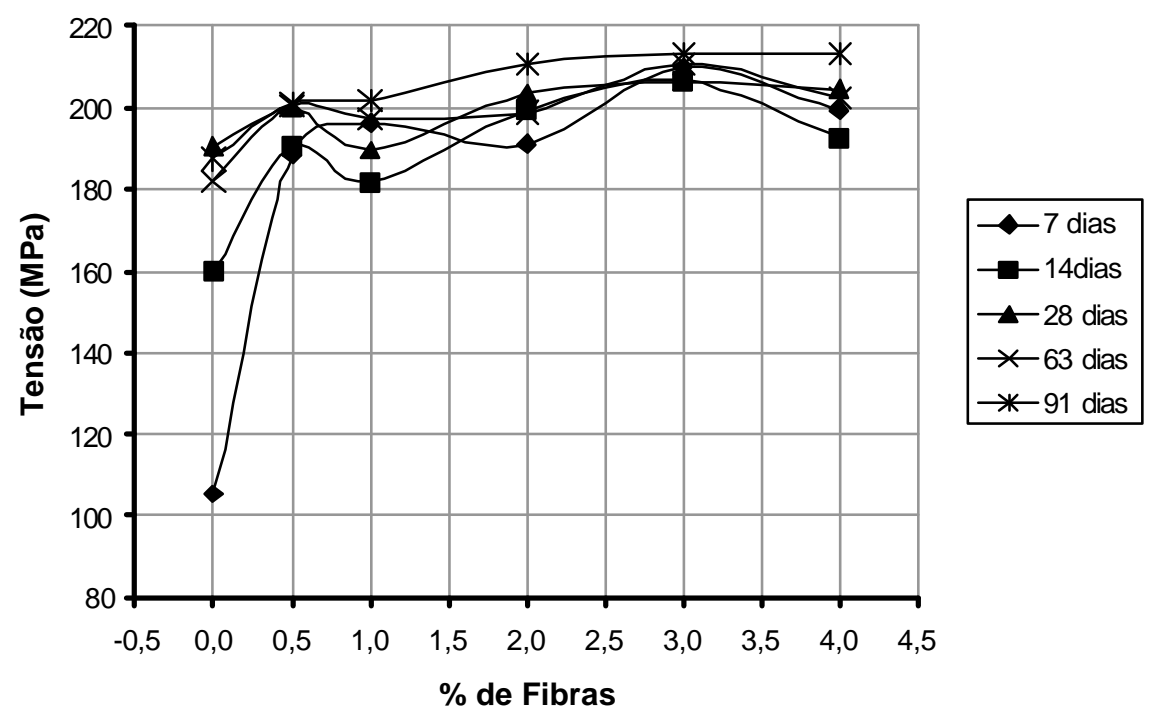

Figura 5.3 - Crescimento da resistência à compressão com o volume de fibras

O aumento da resistência àcompressão em conseqüência da adição de fibras foi mais evidente nas primeiras idades, onde se acredita que em virtude da baixa quantidade de água neste tipo de concreto, a hidratação do cimento ocorreu de forma não homogênea, causando, principalmente nas primeiras idades, regiões com diferentes propriedades mecânicas dentro da massa de concreto. Quando o modelo é submetido a tensões, as regiões menos hidratadas da massa de concreto sofrem fissuras para intensidades de tensões mais baixas que outras regiões, causando a ruptura prematura do modelo. Neste caso, as fibras atuam como pontes de transferência de tensões entre as regiões mais hidratadas, fazendo com que o corposde-prova redistribua as tensões de forma mais homogênea, aumentando assim, sua resistência mecânica. Este comportamento já foi comentado no item 3.4.8. 
O aumento do volume de fibras de $0,5 \%$ até $3 \%$, provocou crescimento na resistência à compressão que variou conforme a idade dos corpos-de-prova. Os modelos com 7 dias apresentaram aumento na resistências de 11,5\%; aqueles com 14 dias a diferença foi de 8,3\%; já para os modelos com idades de 28 até 91 dias, esta diferença ficou em média de 4,8\%. Com isso, acredita-se que, o maior volume de fibras melhora a distribuição de tensões internas entre as regiões mais hidratadas, e que esta propriedade é mais evidenciada nas primeiras idades do concreto, conforme pode-se observar na figura 5.3. Além disso, quanto maior a quantidade de fibras, maior a ductilidade do material, fazendo com que este atinja intensidade de tensões elevadas, por causa da sua maior deformabilidade.

No entanto, o aumento na quantidade de fibras tem um ponto crítico, onde a partir do qual podem ocorrer prejuízos para as propriedades mecânicas do concreto.

\section{2-Análise da Relação Tensão x Deformação}

A relação entre a tensão provocada pela força aplicada no material e sua deformação correspondente, representa um comportamento de grande importância para a engenharia de estruturas. A análise pode ser feita tanto para tensões de compressão, quanto para tração. Por causa da complexidade e imprecisão dos ensaios de tração direta, analisou-se neste trabalho apenas a relação tensão $x$ deformação na compressão.

Para este estudo, foram realizados ensaios de compressão axial em corposde-prova cilíndricos de $50 \mathrm{~mm} \times 100 \mathrm{~mm}$, instrumentados com extensômetros elétricos e carregados com controle de deslocamento do êmbolo da prensa, conforme procedimentos descritos nos itens 4.3.1 e 4.6.2.

A análise foi feita em seis séries, já descritas, com diferentes quantidades de fibras metálicas. Para cada série foram ensaiados 3 corpos-de-prova com idade de 28 dias, e registradas a força aplicada e respectiva deformação longitudinal em intervalos de 0,5 segundos, utilizando o sistema de aquisição de dados.

As deformações longitudinais foram medidas por dois extensômetros elétricos colados a meia altura dos corpos-de-prova e diametralmente opostos, item 4.3.1.2. Assim, a deformação adotada era a média dos valores registrados pelos extensômetros. A tensão foi definida como a relação entra a força aplicada e a área inicial da seção transversal.

As relações tensão $x$ deformação para cada corpo-de-prova são representadas em gráficos, nos quais a tensão é marcada no eixo das ordenadas em $M P a$, e a deformação específica no eixo das abscissa em valores multiplicados por 1000 (\%). 
Em geral, todos os corpos-de-prova ensaiados apresentaram comportamento dos gráficos tensão $x$ deformação de forma retilínea, até atingirem a tensão máxima. Após a ruptura, os ensaios não foram capazes de registrar o desempenho dos corposde-prova, restringindo assim a análise feita para a ductilidade do material.

Os corpos-de-prova da série M1, cuja dosagem não continha fibras metálicas, apresentaram gráficos da relação tensão x deformação mostrados na figura 5.4. Os três corpos-de-prova, denominados M1-1, M1-2, M1-3, atingiram tensão de ruptura e respectiva deformação específica conforme mostrado na tabela 5.3.

Uma análise minuciosa dos gráficos da figura 5.4, mostraram que a relação tensão $x$ deformação apresentou comportamento linear do início até um determinado ponto do ensaio, onde a partir do qual o gráfico apresentou curvatura até a ruptura do corpo-de-prova. O ponto de transição entre o trecho retilíneo e o curvo foi determinado de forma aproximada, analisando visualmente os gráficos, com auxílio de ferramentas computacionais. Assim, o ponto de transição $\left(f_{i}\right)$ foi assumido como uma parcela da resistência a ruptura $\left(f_{c}\right)$ de cada corpos-de-prova ensaiado, esses valores foram mostrado na tabela 5.3 .

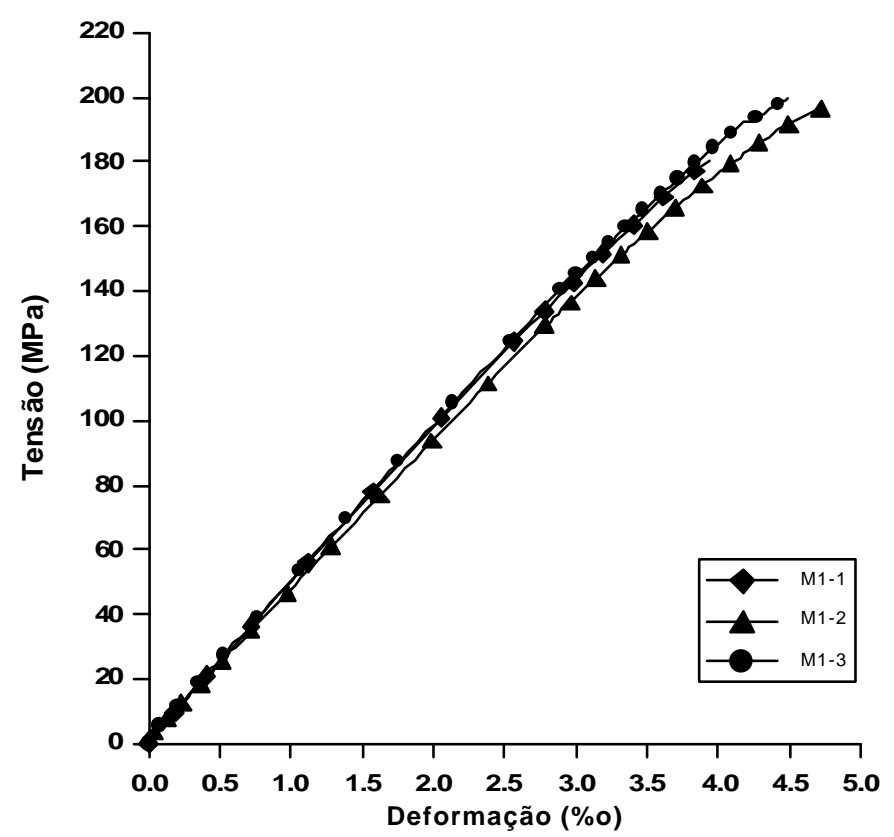

Figura 5.4 - Relação tensão x deformação para os corpos-de-prova da série M1

Para a série $\mathrm{M} 1$, adotou-se o valor médio dos resultados dos ensaios para representar a resistência de ruptura, a deformação específica máxima, e o ponto de transição. No cálculo da média das resistências de ruptura e deformações máximas, não foram considerados os valores do modelo $\mathrm{M} 1-1$, pois este apresentou resultado inferior quando comparado com outros corpos-de-prova. 
Tabela 5.3 - Resultados dos corpos-de-prova da série M1

\begin{tabular}{c|c|c|c}
\hline Modelo & $\begin{array}{c}\text { Deformação máxima } \\
(\%)\end{array}$ & $\begin{array}{c}\text { Tensão de ruptura } \\
(\mathbf{M P a})\end{array}$ & $\begin{array}{c}\text { Ponto de transição } \\
\left(\boldsymbol{f}_{\boldsymbol{i}} / \boldsymbol{f}_{\boldsymbol{c}}\right)\end{array}$ \\
\hline M1-1 & $3,98^{*}$ & $180,9^{*}$ & 0,70 \\
\hline M1-2 & 4,70 & 196,6 & 0,67 \\
\hline M1-3 & 4,49 & 199,6 & 0,71 \\
\hline Média & $\mathbf{4 , 6 0}$ & $\mathbf{1 9 8 , 0 7}$ & $\mathbf{0 , 6 9}$ \\
\hline
\end{tabular}

${ }^{*}$ Valores desconsiderados na análise.

A série $M 2$, contendo $0,5 \%$ do seu volume em fibras, apresentaram gráficos relacionando tensão x deformação como exposto na figura 5.5. Os corpos-de-prova, denominados M2-1, M2-2, M2-3, atingiram resistência de ruptura e respectiva deformação específica conforme mostrado na tabela 5.4.

A forma do gráfico tensão $x$ deformação para esta série foi bilinear, com um trecho retilíneo do início até um determinado ponto do ensaio, seguido por outro trecho, também retilíneo, mas com menor coeficiente angular em relação ao primeiro, até a ruptura do modelo. A tensão no ponto de transição $\left(f_{i}\right)$ entre os dois trechos retilíneos foi assumido como uma parte da resistência de ruptura, esses valores foram mostrado na tabela 5.4 .

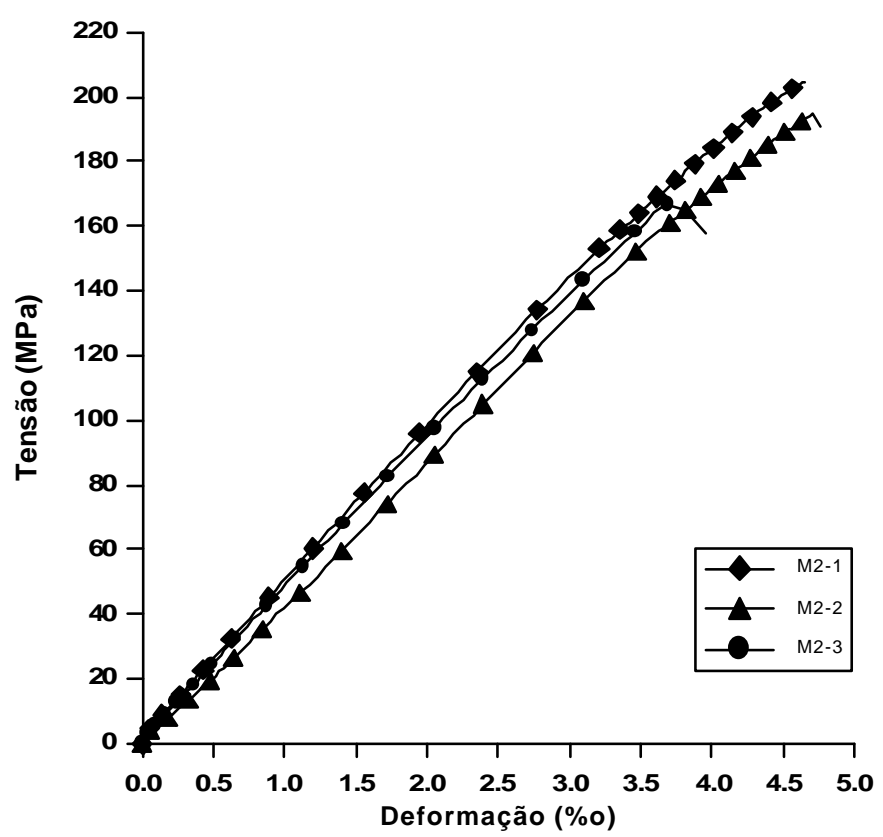

Figura 5.5 - Relação tensão x deformação para os corpos-de-prova da série M2

Para a série M2, o valor médio dos resultados dos ensaios para representar a resistência de ruptura, a deformação específica máxima, e o ponto de transição, são mostrados na tabela 5.4. O corpo-de-prova M2-3 não foi considerado para análise, pois este apresentou comportamento diferente dos demais, provavelmente por problemas no corpo-de-prova. 
Tabela 5.4 - Resultados dos corpos-de-prova da série M2

\begin{tabular}{c|c|c|c}
\hline Modelo & $\begin{array}{c}\text { Deformação máxima } \\
(\%)\end{array}$ & $\begin{array}{c}\text { Tensão de ruptura } \\
(\mathbf{M P a})\end{array}$ & $\begin{array}{c}\text { Ponto de transição } \\
\left(\boldsymbol{f}_{\boldsymbol{i}} / \boldsymbol{f}_{\boldsymbol{c}}\right)\end{array}$ \\
\hline M2-1 & 4,65 & 204,77 & 0,73 \\
\hline M2-2 & 4,71 & 194,77 & 0,77 \\
\hline M2-3 & $3,72^{*}$ & $166,74^{*}$ & $0,69^{*}$ \\
\hline Média & $\mathbf{4 , 6 8}$ & $\mathbf{1 9 9 , 7 7}$ & $\mathbf{0 , 7 3}$ \\
\hline
\end{tabular}

${ }^{*}$ Valores desconsiderados na análise.

Com taxa de $1 \%$ de fibras, os corpos-de-prova da série M3, denominados M31, M3-2, M3-3, apresentaram gráficos relacionando tensão $x$ deformação como exposto na figura 5.6. Os corpos-de-prova atingiram resistência de ruptura e respectiva deformação específica conforme mostrado na tabela 5.5.

A forma do gráfico tensão $x$ deformação para esta série também foi bilinear, com um trecho retilíneo do início do ensaio, seguido por outro trecho, também retilíneo, mas com menor coeficiente angular. $O$ ponto de transição entre os dois trechos retilíneos foi assumido como uma parcela da resistência de ruptura, esses valores foram mostrado na tabela 5.5 .

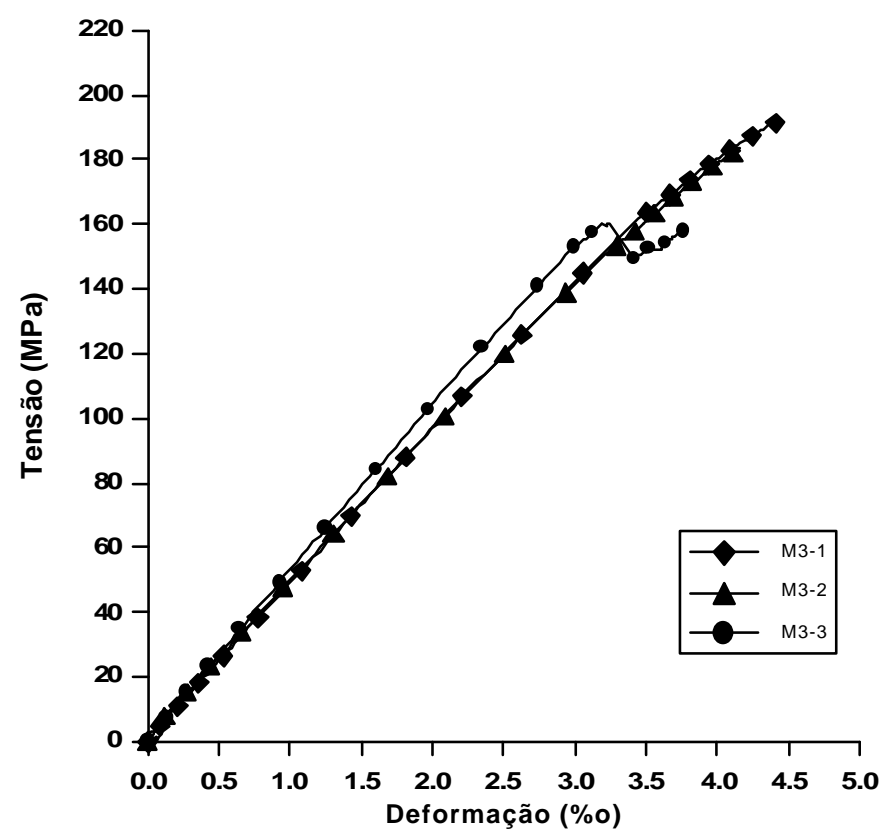

Figura 5.6 - Relação tensão x deformação para os corpos-de-prova da série M3

$\mathrm{Na}$ análise dos resultados da série $\mathrm{M} 3$, não foi considerado os valores do corpo-de-prova M3-3, pois este apresentou diferenças consideráveis no seu comportamento, fornecendo dados não comparáveis com os demais corpos-de-prova. O valor médio dos resultados dos ensaios para representar a resistência de ruptura, a deformação específica máxima, e o ponto de transição, são mostrados na tabela 5.5. 
Tabela 5.5 - Resultados dos corpos-de-prova da série M3

\begin{tabular}{c|c|c|c}
\hline Modelo & $\begin{array}{c}\text { Deformação máxima } \\
(\%)\end{array}$ & $\begin{array}{c}\text { Tensão de ruptura } \\
(\mathbf{M P a})\end{array}$ & $\begin{array}{c}\text { Ponto de transição } \\
\left(\boldsymbol{f}_{\boldsymbol{i}} / \boldsymbol{f}_{\boldsymbol{c}}\right)\end{array}$ \\
\hline M3-1 & 4,42 & 191,80 & 0,83 \\
\hline M3-2 & 4,09 & 183,86 & 0,82 \\
\hline M3-3 & $3,24^{*}$ & $160,39^{*}$ & $0,75^{\star}$ \\
\hline Média & $\mathbf{4 , 2 6}$ & $\mathbf{1 8 7 , 8 3}$ & $\mathbf{0 , 8 3}$ \\
\hline
\end{tabular}

${ }^{*}$ Valores desconsiderados na análise.

Os corpos-de-prova da série M4, que continha $2 \%$ do volume em fibras metálicas, apresentaram relação tensão x deformação, figura 5.7. Os três corpos-deprova, denominados M4-1, M4-2, M4-3, atingiram resistência de ruptura e respectiva deformação específica de acordo com os valores mostrados na tabela 5.6.

A forma do gráfico tensão $\mathrm{x}$ deformação para esta série foi semelhante aos das séries M2 e M3, com um trecho retilíneo do início até um determinado ponto do ensaio, seguido por outro trecho, também retilíneo, com menor coeficiente angular em relação ao primeiro, até a ruptura do modelo. O ponto de transição entre os dois trechos retilíneos foi assumido de forma aproximada, como uma parcela da tensão de ruptura, esses valores foram mostrado na tabela 5.6.

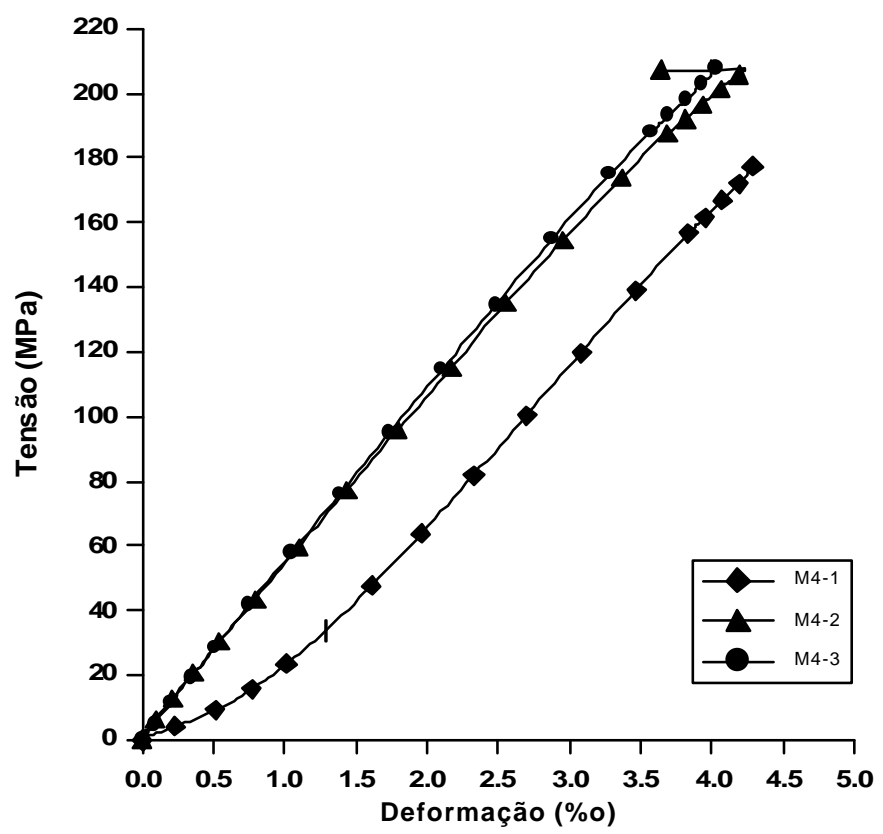

Figura 5.7 - Relação tensão x deformação para os corpos-de-prova da série M4

Observando a figura 5.7, verifica-se que o gráfico do corpo-de-prova M4-1 apresentou comportamento diferente dos demais, fornecendo valores para a resistência de ruptura e ponto de transição não comparáveis com os demais corposde-prova. O valor médio dos resultados dos ensaios para representar a resistência de ruptura, a deformação específica máxima, e o ponto de transição, são mostrados na tabela 5.6. 
Tabela 5.6 - Resultados dos corpos-de-prova da série M4

\begin{tabular}{c|c|c|c}
\hline Modelo & $\begin{array}{c}\text { Deformação máxima } \\
(\%)\end{array}$ & $\begin{array}{c}\text { Tensão de ruptura } \\
(\mathbf{M P a})\end{array}$ & $\begin{array}{c}\text { Ponto de transição } \\
\left(\boldsymbol{f}_{\boldsymbol{i}} / \mathbf{f}_{\mathbf{c}}\right)\end{array}$ \\
\hline M4-1 & 4,29 & $177,00^{*}$ & $0,88^{*}$ \\
\hline M4-2 & 4,24 & 207,45 & 0,60 \\
\hline M4-3 & 4,04 & 208,93 & 0,60 \\
\hline Média & $\mathbf{4 , 1 9}$ & $\mathbf{2 0 8 , 1 9}$ & $\mathbf{0 , 6 0}$ \\
\hline
\end{tabular}

* Valores desconsiderados na análise.

A série M5 continha na dosagem $3 \%$ do seu volume em fibras. A relação tensão x deformação, proveniente dos ensaios dos corpos-de-prova M5-1, M5-2 e M53, são expostas na figura 5.8 .

A relação tensão $x$ deformação apresenta comportamento gráfico semelhante aos das séries anteriores que continham fibras, ou seja, bilinear, com um trecho retilíneo do início até um determinado ponto do ensaio, seguido por outro trecho, também retilíneo, com menor coeficiente angular em relação ao primeiro, até a ruptura do corpo-de-prova. A resistência de ruptura, e respectiva deformação específica máxima, assim como, o ponto de transição entre os dois trechos retilíneos, são apresentados na tabela 5.7 .

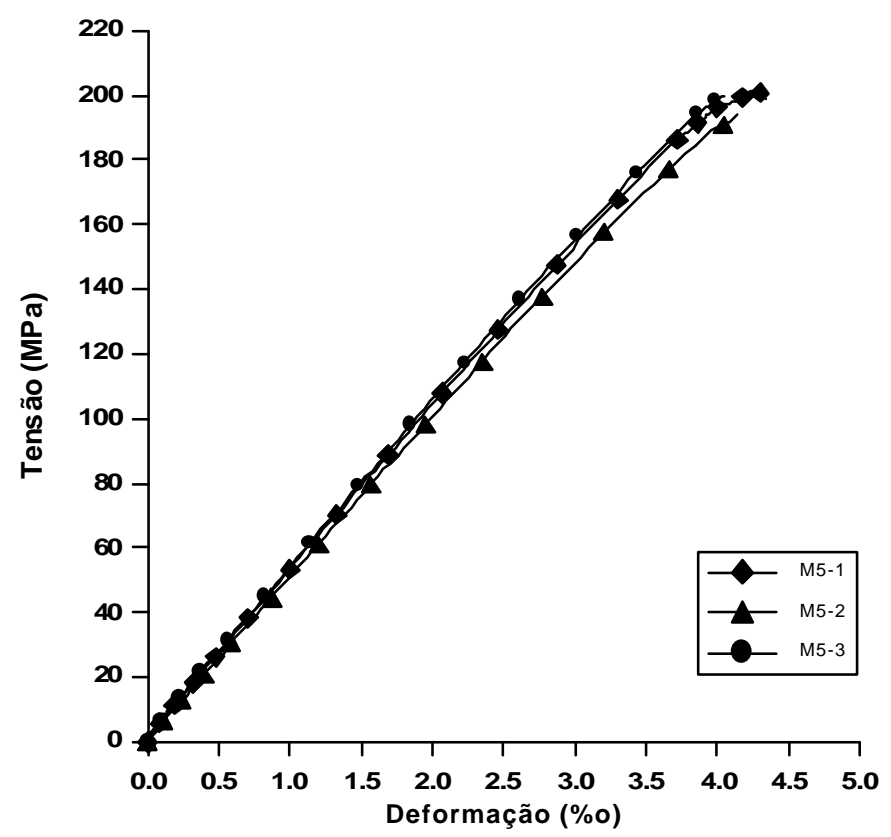

Figura 5.8 - Relação tensão x deformação para os corpos-de-prova da série M5

Os três corpos-de-prova da série M5 não apresentaram problemas que causassem o descarte de algum modelo na análise dos resultados. O valor médio dos ensaios para representar a resistência de ruptura, a deformação específica máxima, e o ponto de transição, são mostrados na tabela 5.7 . 
Tabela 5.7 - Resultados dos corpos-de-prova da série M5

\begin{tabular}{c|c|c|c}
\hline Modelo & $\begin{array}{c}\text { Deformação máxima } \\
(\%)\end{array}$ & $\begin{array}{c}\text { Tensão de ruptura } \\
(\mathbf{M P a})\end{array}$ & $\begin{array}{c}\text { Ponto de transição } \\
\left(\boldsymbol{f}_{\boldsymbol{i}} / \boldsymbol{f}_{\boldsymbol{c}}\right)\end{array}$ \\
\hline M5-1 & 4,28 & 200,90 & 0,50 \\
\hline M5-2 & 4,15 & 194,10 & 0,62 \\
\hline M5-3 & 4,04 & 200,08 & 0,50 \\
\hline Média & $\mathbf{4 , 1 6}$ & $\mathbf{1 9 8 , 3 6}$ & $\mathbf{0 , 5 4}$ \\
\hline
\end{tabular}

A série M6, com taxa de $4 \%$ do seu volume em fibras, apresentaram relação tensão x deformação, proveniente dos ensaios dos corpos-de-prova M6-1, M6-2 e M63 , conforme os gráficos da figura 5.9.

As relações tensão $\mathrm{x}$ deformação também apresentaram comportamento gráfico bilinear, com um trecho retilíneo do início até um determinado ponto do ensaio, seguido por outro trecho, também retilíneo, com menor coeficiente angular em relação ao primeiro, até a ruptura do modelo. A resistência de ruptura, e respectiva deformação específica máxima, assim como, o ponto de transição entre os dois trechos retilíneos são apresentados na tabela 5.8 .

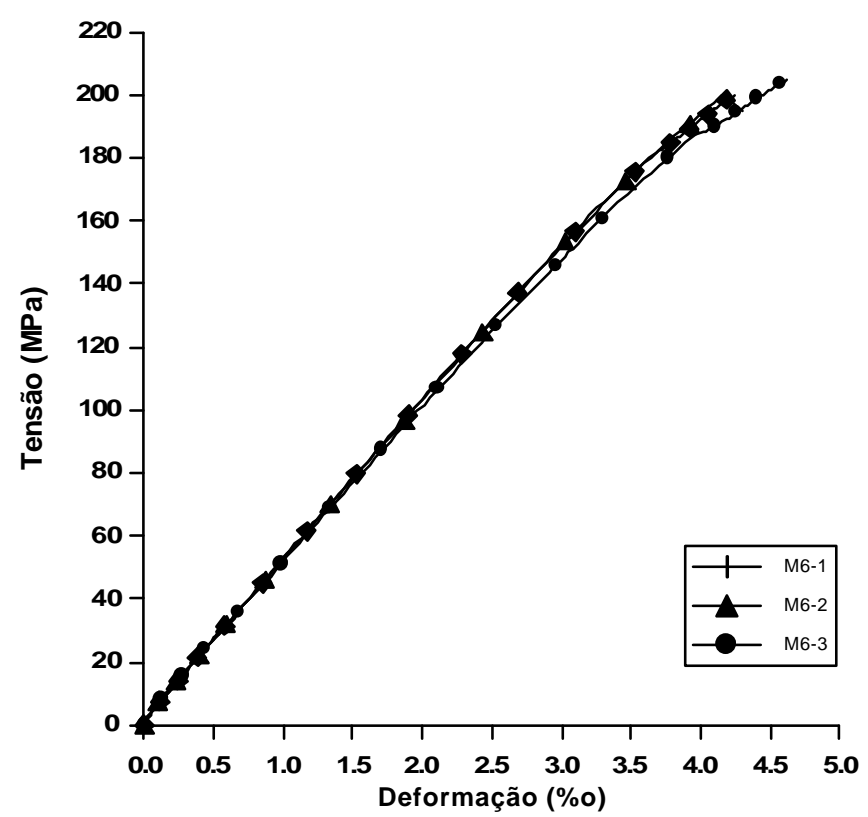

Figura 5.9 - Relação tensão x deformação para os corpos-de-prova da série M6

Os três modelos da série M6 não apresentaram problemas. O valor médio dos ensaios para representar a resistência de ruptura, a deformação específica máxima, e o ponto de transição, são mostrados na tabela 5.8. 
Tabela 5.8 - Resultados dos corpos-de-prova da série M6

\begin{tabular}{c|c|c|c}
\hline Modelo & $\begin{array}{c}\text { Deformação máxima } \\
(\%)\end{array}$ & $\begin{array}{c}\text { Tensão de ruptura } \\
(\mathbf{M P a})\end{array}$ & $\begin{array}{c}\text { Ponto de transição } \\
\left(\boldsymbol{f}_{\boldsymbol{i}} / \boldsymbol{f}_{\boldsymbol{c}}\right)\end{array}$ \\
\hline M6-1 & 4,26 & 199,89 & 0,63 \\
\hline M6-2 & 4,20 & 200,29 & 0,50 \\
\hline M6-3 & 4,62 & 204,50 & 0,52 \\
\hline Média & $\mathbf{4 , 3 6}$ & $\mathbf{2 0 1 , 5 6}$ & $\mathbf{0 , 5 5}$ \\
\hline
\end{tabular}

Assim, pode-se dizer que a relação tensão $x$ deformação para o concreto de pós reativos estudado neste trabalho, apresenta, de forma geral, um comportamento bilinear, com trecho inicial retilíneo, até um determinado ponto de transição, e em seguida outro trecho retilíneo até a ruptura.

A tabela 5.9 apresenta um resumo com os valores médios das deformações máximas, resistência de ruptura e ponto de transição.

Tabela 5.9 - Resumo dos resultados médios de cada série

\begin{tabular}{c|c|c|c}
\hline Séries & $\begin{array}{c}\text { Deformação máxima } \\
(\mathbf{\%})\end{array}$ & $\begin{array}{c}\text { Tensão de ruptura } \\
(\mathbf{M P a})\end{array}$ & $\begin{array}{c}\text { Ponto de transição } \\
\left(\boldsymbol{f}_{\boldsymbol{i}} / \boldsymbol{f}_{\boldsymbol{c}}\right)\end{array}$ \\
\hline M1 & 4,60 & 198,07 & 0,69 \\
\hline M2 & 4,68 & 199,77 & 0,73 \\
\hline M3 & 4,26 & 187,83 & 0,82 \\
\hline M4 & 4,19 & 208,19 & 0,60 \\
\hline M5 & 4,16 & 198,36 & 0,54 \\
\hline M6 & 4,36 & 201,56 & 0,55 \\
\hline
\end{tabular}

O ponto de transição, segundo os ensaios realizados, varia em função do volume de fibras na mistura, onde pode-se observar, na figura 5.10, que a relação $(\alpha)$ entre a tensão correspondente ao ponto de transição e a resistência máxima $\left(\alpha=f_{i} /\right.$ $f_{c}$ ), apresentou comportamento crescente para as séries com taxas de fibras de $0 \%$ até $1 \%$, e decrescente para as demais. Pode-se supor que existe um volume de fibras entre as taxas de $1 \%$ e $2 \%$, a partir do qual o material tende a apresentar as primeiras fissuras para intensidades de tensão mais baixas, que pode ser explicado pelo aumento de imperfeições na microestrutura do concreto, por causa do excesso de fibras. No entanto, esta hipótese necessita ser comprovada.

O ponto de transição pode ser determinado pela a linha de tendência da figura 5.10, que corresponde a um polinômio do quarto grau representado pela equação 5.2.

$$
\begin{aligned}
& f_{i}=\alpha \cdot f_{c} \\
& \alpha=-0,0086 \mathrm{~V}_{\mathrm{f}}^{4}+0,0988 \mathrm{~V}_{\mathrm{f}}^{3}-0,3561 \mathrm{~V}_{\mathrm{f}}{ }^{2}+0,3609 \mathrm{~V}_{\mathrm{f}}+0,6764
\end{aligned}
$$

onde: $\quad f_{i}=$ tensão no ponto de transição;

$f_{c}=$ resistência de ruptura;

$\alpha=$ coeficiente de redução da tensão de ruptura;

$V_{f}=$ taxa de fibras em volume, multiplicada por 100 . 


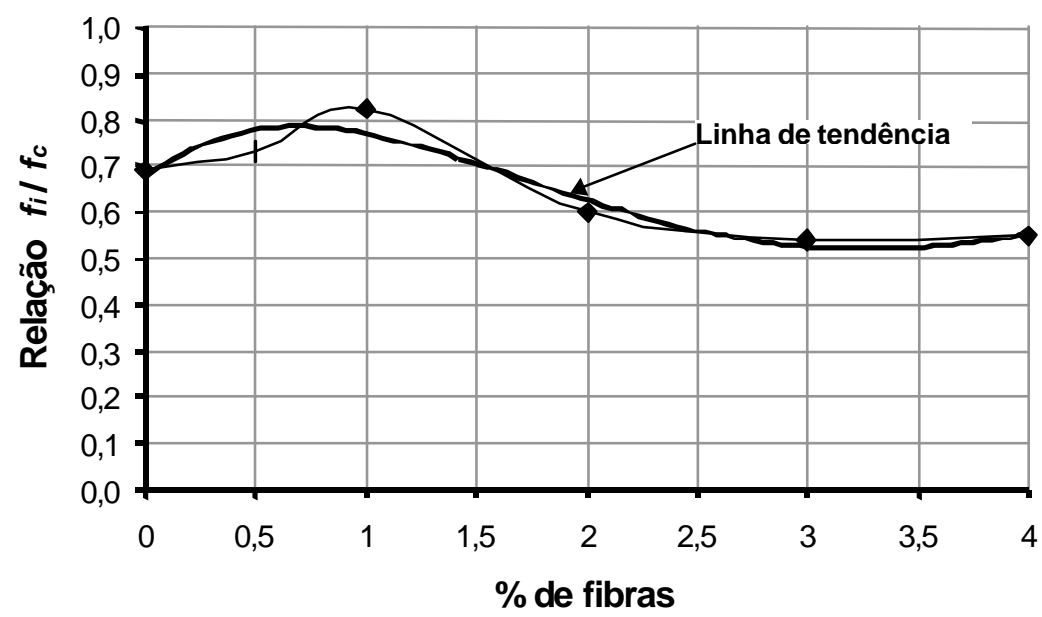

Figura 5.10 - Relação entre o volume de fibras e o coeficiente " $\alpha=f_{i} / f_{c}$ ".

A diferença entre os dois trechos retilíneos é o coeficiente angular das duas retas, onde a segunda apresenta sempre um valor menor que a primeira. $A$ inclinação do primeiro trecho pode ser entendida como sendo o módulo de deformação longitudinal do concreto de pós reativos. Como para o segundo trecho esse valor é reduzido, isto significa que o material apresenta um decréscimo no valor do módulo de deformação longitudinal, tornando-se mais deformável a partir do ponto de transição.

Assim, pode-se propor um comportamento para a relação tensão x deformação na compressão do concreto de pós reativos. No entanto, esta proposta depende basicamente do módulo de deformação longitudinal do material, e do decréscimo desse valor a partir do ponto de transição, além de limitações provenientes da deformação específica máxima. Com isso, será analisado nos próximos itens, o módulo de deformação longitudinal e as deformações específicas máximas, e em seguida, será proposta uma relação constitutiva para o concreto de pós reativos, baseada nos ensaios realizados.

\section{3- Módulo de Deformação Longitudinal}

O módulo de deformação longitudinal, também conhecido como "Módulo de Elasticidade", é uma propriedade física do material, e representa a capacidade de deformação quando submetido a algum tipo de carregamento. A maneira mais simples de medir esta capacidade de deformação é por meio da curva tensão x deformação, onde o módulo de elasticidade representa a inclinação da reta tangente em um ponto da curva. Partindo deste princípio, existe um módulo de elasticidade para cada ponto da curva, sendo assim, um parâmetro variável em função da intensidade de carregamento aplicado.

Para fins estruturais, o módulo de elasticidade é padronizado em duas formas: módulo de elasticidade tangente na origem, e módulo de elasticidade secante. $\mathrm{O}$ 
primeiro representa a capacidade de deformação do material para pequenas intensidades de carregamento, já o segundo é utilizado quando o carregamento está próximo da resistência de serviço do material, porém, ainda no regime elástico.

É sabido que o módulo de elasticidade é função da resistência do concreto, pois a medida que se aumenta a capacidade resistente do concreto, a relação tensão $x$ deformação apresenta-se de forma mais linear até a ruptura, tornando os valores do módulo de elasticidade tangente e secante bem próximos.

Para o concreto de pós reativos, o módulo de elasticidade foi medido por meio dos ensaios de compressão axial com controle de deslocamento, em corpos-de-prova cilíndricos de $50 \mathrm{~mm} \times 100 \mathrm{~mm}$, com instrumentação e procedimentos descritos no item 4.6.2.

A análise do módulo de elasticidade foi feita para a idade de 28 dias, nas seis séries já descritas, com diferentes quantidades de fibras metálicas. Para cada série foram ensaiados 3 corpos-de-prova e registrados a força aplicada e deformação longitudinal correspondente durante todo o ensaio.

Com os resultados de cada corpo-de-prova ensaiado, foram montados os gráficos tensão $x$ deformação, segundo descrito no item 5.2, e por meio destes foram analisados os valores da inclinação dos trechos retilíneos, desde o início, até a ruptura dos corpos-de-prova. Conforme observado anteriormente, os gráficos tensão $\mathrm{x}$ deformação apresentaram dois trechos retilíneos, onde o primeiro era delimitado pelo início do ensaio até o ponto de transição, e o segundo trecho prossegui até a resistência de ruptura.

Como o módulo de deformação é definido para o trecho onde o material apresenta comportamento elástico linear, então, adotou-se o coeficiente angular do primeiro trecho retilíneo do gráfico tensão x deformação como módulo de elasticidade para o CPR.

Para cada modelo foram medidos o coeficiente angular do primeiro trecho, designado por " $E_{1}$ ", e do segundo trecho, " $E_{2}$ ", no gráfico tensão x deformação. Os valores são mostrados na tabela 5.10. A relação ' $\boldsymbol{\beta}=E_{1} / E_{2}$ " representa a redução que o módulo de elasticidade apresentou entre o primeiro e o segundo trecho, esses valores variaram de acordo com cada série, e foram relacionados na tabela 5.10.

Com esses resultados, pode-se analisar a interferência do volume de fibras no valor do módulo de elasticidade, conforme mostrado na figura 5.11. Assim, verifica-se que para as séries M1 e M2, com baixa quantidade de fibras, os módulos de deformação longitudinal foram inferiores, comparados com os módulos medidos para as séries com maior quantidade de fibras. No entanto, a diferença foi muito pequena, cerca de $8 \%$, podendo assim considerar que, o módulo de elasticidade não apresentou 
influência direta do volume de fibras utilizado na mistura, permanecendo praticamente constante para todas as série.

Tabela 5.10 - Módulo de elasticidade para cada corpo-de-prova

\begin{tabular}{c|c|c|c}
\hline Modelos & $\begin{array}{c}\text { Módulo de Elasticidade } \\
E_{\mathbf{1}}(\mathrm{GPa})\end{array}$ & $\begin{array}{c}\text { Módulo de Elasticidade } \\
\boldsymbol{E}_{\mathbf{2}}(\mathrm{GPa})\end{array}$ & $\begin{array}{c}\text { Relação } \\
\boldsymbol{\beta}=\mathrm{E}_{\mathbf{1}} / \mathrm{E}_{\mathbf{2}}\end{array}$ \\
\hline M1-1 & 47,981 & 42,331 & 0,882 \\
\hline M1-2 & 45,878 & 37,028 & 0,807 \\
\hline M1-3 & 48,029 & 40,166 & 0,836 \\
\hline Média & $\mathbf{4 7 , 2 9 6}$ & $\mathbf{3 9 , 8 4 2}$ & $\mathbf{0 , 8 4 2}$ \\
\hline M2-1 & 47,263 & 37,931 & 0,803 \\
\hline M2-2 & 45,111 & 34,447 & 0,764 \\
\hline M2-3 & 46,543 & 41,512 & 0,892 \\
\hline Média & $\mathbf{4 6 , 3 0 6}$ & $\mathbf{3 7 , 9 6 3}$ & $\mathbf{0 , 8 1 9}$ \\
\hline M3-1 & 47,564 & 31,132 & 0,655 \\
\hline M3-2 & 46,872 & 35,951 & 0,767 \\
\hline M3-3 & 51,739 & 48,739 & 0,942 \\
\hline Média & $\mathbf{4 8 , 7 2 5}$ & $\mathbf{3 8 , 6 0 7}$ & $\mathbf{0 , 7 9 2}$ \\
\hline M4-1 & $47,549^{*}$ & 44,363 & 0,933 \\
\hline M4-2 & 55,506 & 47,739 & 0,860 \\
\hline M4-3 & 53,743 & 50,136 & 0,933 \\
\hline Média & $\mathbf{5 4 , 6 2 4}$ & $\mathbf{4 8 , 9 3 8}$ & $\mathbf{0 , 9 0 9}$ \\
\hline M5-1 & 50,916 & 47,713 & 0,937 \\
\hline M5-2 & 49,547 & 44,956 & 0,907 \\
\hline M5-3 & 51,502 & 48,225 & 0,936 \\
\hline Média & $\mathbf{5 0 , 6 5 5}$ & $\mathbf{4 6 , 9 6 5}$ & $\mathbf{0 , 9 2 7}$ \\
\hline M6-1 & 50,412 & 43,945 & 0,872 \\
\hline M6-2 & 50,292 & 46,245 & 0,920 \\
\hline M6-3 & 48,923 & 33,856 & 0,692 \\
\hline Média & $\mathbf{4 9 , 8 7 6}$ & $\mathbf{4 1 , 3 4 9}$ & $\mathbf{0 , 8 9 6}$ \\
\hline Vabs & &
\end{tabular}

*Valores desconsiderados na análise.

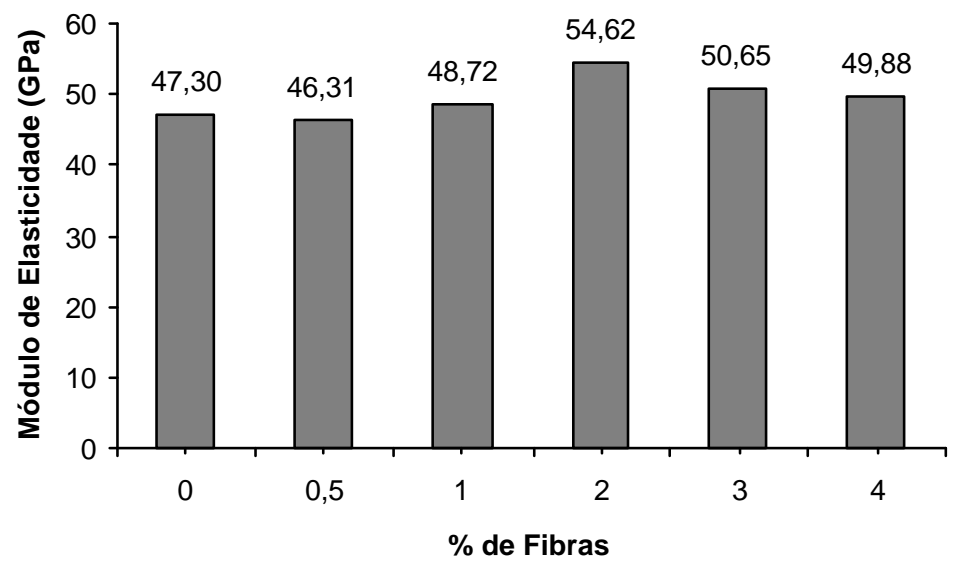

Figura 5.11 - Influência do volume de fibras no módulo de elasticidade do CPR

Quanto ao coeficiente de redução " $\beta=E_{2} / E_{1}$ ", verifica-se, pela figura 5.12, que este apresenta tendência de crescimento quando aumentada a quantidade de fibras no concreto. Isto significa que, ao aumentar a quantidade de fibras no concreto de pós reativos, a redução para os coeficientes angulares entre o primeiro e segundo trecho do gráfico tensão $x$ deformação é menor. O que leva a crer que as fibras atuam como 
pontes de distribuição de tensões internas, minimizando a não linearidade física proveniente das fissuras internas do concreto, fazendo com que o material se torne mais dúctil, porém, com maior rigidez.

O comportamento do coeficiente de redução " $\boldsymbol{\beta}=E_{2} / E_{1}$ " pode ser aproximado por uma reta, conforme linha de tendência mostrada na figura 5.12. Para os ensaios realizados nesta pesquisa, esta reta pode ser representada pela equação 5.3 .

$$
\beta=0,03 \cdot V_{f}+0,8
$$

onde: $\beta=$ coeficiente de redução do módulo de elasticidade;

$V_{f}=$ taxa de fibras em volume, multiplicada por 100.

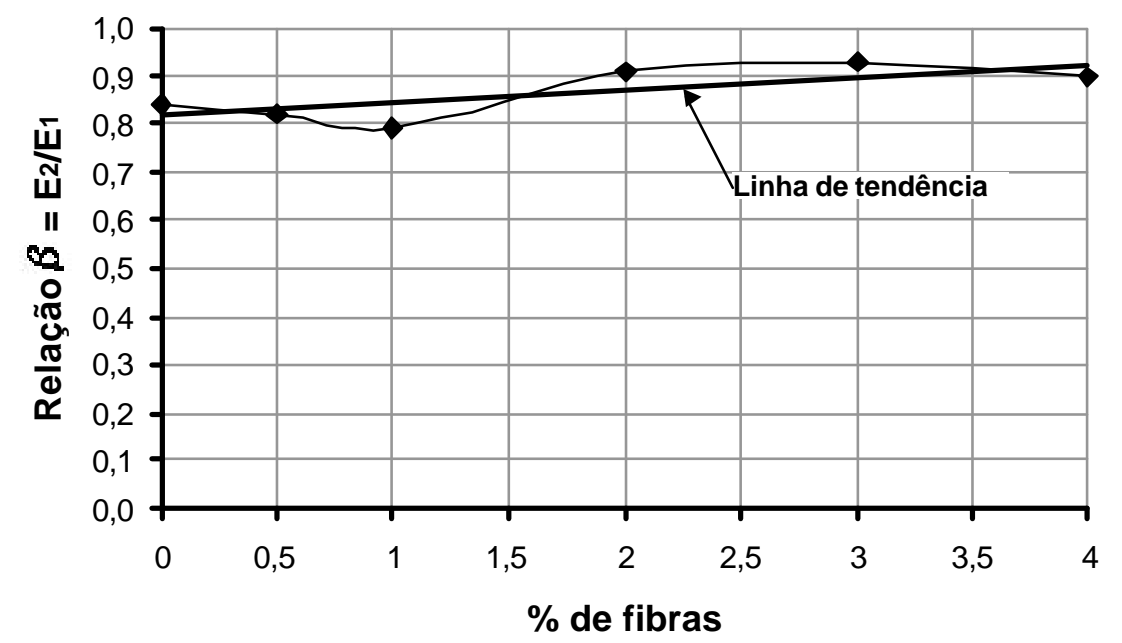

Figura 5.12 - Relação entre o volume de fibras e o coeficiente " $\beta=E_{2}$ / $E_{1}$ ".

De acordo com as publicações técnicas a respeito do módulo de elasticidade para o concreto de pós reativos, pode-se fazer uma comparação entre os valores medidos nos ensaios realizados nesta pesquisa, e os publicados na literatura.

A maioria dos trabalhos consultados relacionam um valor médio para o módulo de elasticidade do CPR sem fibras e outro para o CPR com fibras. Assim, adotando a mesma convenção, assumiu-se como módulo de elasticidade para o CPR sem fibras o valor médio dos modelos da série $\mathrm{M} 1$, e considerado como módulo de elasticidade para CPR com fibras, a média dos valor medidos nos modelos das séries M3, M4, M5 e M6.

A tabela 5.11 traz os valores dos módulos de elasticidade alcançados nesta pesquisa, e os divulgados em alguns artigos científicos. Verifica-se que os valores alcançados ficaram próximos dos obtidos por BEHLOUL et al. (1996) e BONNEAU et al. (1996), tanto para os concreto sem fibras quanto para os com fibras. 
Tabela 5.11 - Comparação dos módulos de elasticidade da pesquisa e obtidos por outros autores

\begin{tabular}{l|c|c}
\hline \multirow{2}{*}{ Estudo } & \multicolumn{2}{|c}{ Módulo de elasticidade (GPa) } \\
\cline { 2 - 3 } & sem fibras & com fibras \\
\hline Nesta pesquisa & 47,3 & 51,0 \\
\hline Richard \& Cheyrezy (1994) & 54,0 & 60,0 \\
\hline Dugat et al. (1995) & 62,0 & 66,0 \\
\hline Behloul et al. (1996) & 40,6 & 43,0 \\
\hline Bonneau et al. (1996) & 46,0 & 49,0 \\
\hline
\end{tabular}

A análise demostra que o concreto desenvolvido nesta pesquisa apresenta propriedades semelhantes aqueles que foram desenvolvidos por outros pesquisadores, mesmo utilizando materiais, dosagem e técnicas de preparo diferentes.

\section{4- Deformação Específica na Compressão}

A medida que um corpo é submetido a um carregamento, este sofre mudanças de dimensões, que representam as deformações decorrentes do carregamento aplicado. Para analisar as deformações provocadas por determinado carregamento, sem a influência das dimensões do corpo, é necessário utilizar o conceito de deformação específica, que é a relação entre a deformação e a dimensão inicial, sendo assim, um parâmetro adimensional.

Em dimensionamento de estruturas, é comum limitar a deformação específica máxima que um determinado material pode sofrer, a fim de garantir maior segurança a estrutura. A análise deste parâmetro é feita por ensaios de compressão ou tração axial, em corpos-de-prova dos materiais.

Para o concreto de pós reativos, a deformação específica foi analisada por meio dos ensaios de compressão axial com controle de deslocamento, em modelos cilíndricos de $50 \mathrm{~mm} \times 100 \mathrm{~mm}$, com instrumentação e procedimentos descritos no item 4.6.2.

A deformação específica foi medida para a idade de 28 dias, nas seis séries já descritas, com diferentes quantidades de fibras metálicas. Para cada série foram ensaiados 3 modelos e registrados a força aplicada e deformação específica, durante todo o ensaio.

Os resultados destes ensaios resultaram na análise já descrita no item 5.2 , onde foi relacionada a tensão provocada pela força aplicada, com a deformação específica correspondente.

A tabela 5.12 mostra os valores das deformações específicas máximas $\left(\varepsilon_{\text {máx }}\right)$, referente a resistência de ruptura, e as deformações específicas referentes a tensão no ponto de transição entre os trechos retilíneos $\left(\varepsilon_{\mathrm{i}}\right)$, comentados no item 5.2. 
Com esses resultados, pode-se analisar a interferência do volume de fibras na deformação específica máxima, onde a figura 5.13 mostra que para as séries M1 e M2, com baixa quantidade de fibras, as deformações específicas máximas foram superiores, comparadas com as deformações para as séries com maior quantidade de fibras. No entanto, a diferença foi muito pequena, cerca de $9 \%$, podendo assim, considerar que as deformações específicas máximas não sofrem influência direta do volume de fibras utilizado na mistura, permanecendo praticamente constante para todas as série.

Tabela 5.12 - Deformações específicas máximas e no ponto de transição

\begin{tabular}{c|c|c|c}
\hline Modelos & $\begin{array}{c}\text { Deformação específica } \\
\text { máxima } \\
\boldsymbol{\varepsilon}_{\text {máx }}(\%)\end{array}$ & $\begin{array}{c}\text { Deformação específica } \\
\text { no ponto de transição } \\
\boldsymbol{\varepsilon}_{\mathbf{i}}(\%)\end{array}$ & $\begin{array}{c}\text { Relação } \\
\boldsymbol{\varepsilon}_{\mathbf{i}} / \boldsymbol{\varepsilon}_{\text {máx }}\end{array}$ \\
\hline M1-1 & $3,98^{*}$ & $2,60^{*}$ & --- \\
\hline M1-2 & 4,70 & 2,82 & 0,600 \\
\hline M1-3 & 4,49 & 2,90 & 0,646 \\
\hline Média & $\mathbf{4 , 6 0}$ & $\mathbf{2 , 8 6}$ & $\mathbf{0 , 6 2 3}$ \\
\hline M2-1 & 4,65 & 3,12 & 0,671 \\
\hline M2-2 & 4,71 & 3,41 & 0,724 \\
\hline M2-3 & $3,72^{*}$ & $2,45^{*}$ & --- \\
\hline Média & $\mathbf{4 , 6 8}$ & $\mathbf{3 , 2 7}$ & $\mathbf{0 , 6 9 7}$ \\
\hline M3-1 & 4,42 & 3,41 & 0,771 \\
\hline M3-2 & 4,09 & 3,20 & 0,782 \\
\hline M3-3 & $3,24^{*}$ & $2,32^{*}$ & --- \\
\hline Média & $\mathbf{4 , 2 6}$ & $\mathbf{3 , 3 1}$ & $\mathbf{0 , 7 7 7}$ \\
\hline M4-1 & 4,29 & $3,80^{*}$ & --- \\
\hline M4-2 & 4,24 & 2,36 & 0,557 \\
\hline M4-3 & 4,04 & 2,30 & 0,569 \\
\hline Média & $\mathbf{4 , 1 9}$ & $\mathbf{2 , 3 3}$ & $\mathbf{0 , 5 6 3}$ \\
\hline M5-1 & 4,28 & 1,90 & 0,444 \\
\hline M5-2 & 4,15 & 2,40 & 0,578 \\
\hline M5-3 & 4,04 & 1,89 & 0,468 \\
\hline Média & $\mathbf{4 , 1 6}$ & $\mathbf{2 , 0 6}$ & $\mathbf{0 , 4 9 7}$ \\
\hline M6-1 & 4,26 & 2,44 & 0,573 \\
\hline M6-2 & 4,20 & 1,94 & 0,462 \\
\hline M6-3 & 4,62 & $3,05^{*}$ & --- \\
\hline Média & $\mathbf{4 , 3 6}$ & $\mathbf{2 , 1 9}$ & $\mathbf{0 , 5 1 7}$ \\
\hline *Valores desconsiderados na análise. & & \\
\hline
\end{tabular}

A tabela 5.12 também fornece a relação entre a deformação específica no ponto de transição e a deformação específica máxima. Analisando estes valores, pode-se constatar que para os modelos contento $0 \%, 0,5 \%$ e $1 \%$ de fibras, o ponto de transição ocorria, em média, com deformação específica equivalente a $0,7 \varepsilon_{\text {máx }}$, todavia, para os modelos com maior quantidade de fibras, o mesmo ocorria geralmente com deformação específica equivalente a $0,53 \varepsilon_{\text {máx }}$. 
As deformações específicas máximas à compressão atingiram, em média, o valor de 4,3\%o, esta deformação pode ser adotada como sendo a deformação específica de ruptura para o concreto de pós reativos.

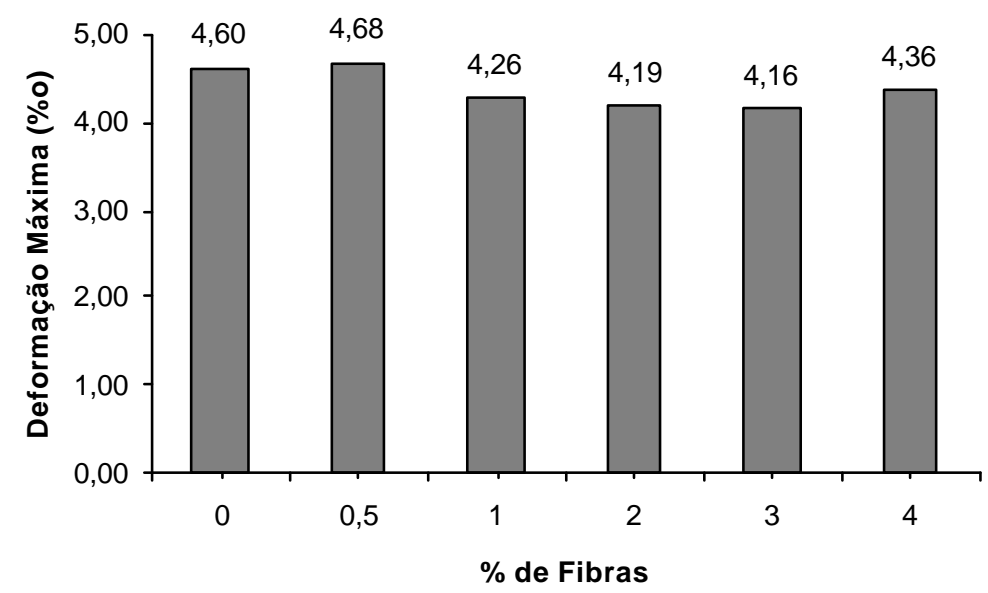

Figura 5.13 - Influência do volume de fibras na deformação máxima de compressão

\section{5- Proposta para Relação Constitutiva do Concreto de Pós Reativos}

Analisando os resultados dos ensaios realizados nesta pesquisa, percebe-se que a relação tensão $x$ deformação, para o concreto de pós reativos, apresenta comportamento bilinear, com dois segmentos retas se cruzando em um ponto de transição, conforme descrito no item 5.2 deste capítulo.

De acordo com a análise já exposta sobre a definição do ponto de transição $\left(f_{i}\right)$, e o comportamento do módulo de elasticidade $(E)$, descritas nos itens 5.3 e 5.4, propõe-se que a relação constitutiva para o concreto de pós reativos submetido a tensões de compressão, seja definida de acordo com o exposto na figura 5.14.

Assim, a relação constitutiva é representada por duas retas, onde:

- o segmento de reta "a" possui coeficiente angular igual ao módulo de elasticidade do material $(E)$, e compreende as deformações relativas as tensões entre zero e o ponto de transição $\left(f_{i}\right)$;

- o segmento de reta "b" possui coeficiente angular igual ao módulo de elasticidade do material, multiplicado pelo coeficiente " $\beta$ " ( $\beta . E)$, e compreende as deformações relativas as tensões entre o ponto de transição $\left(f_{i}\right)$ e a tensão de ruptura $\left(f_{c}\right)$. 


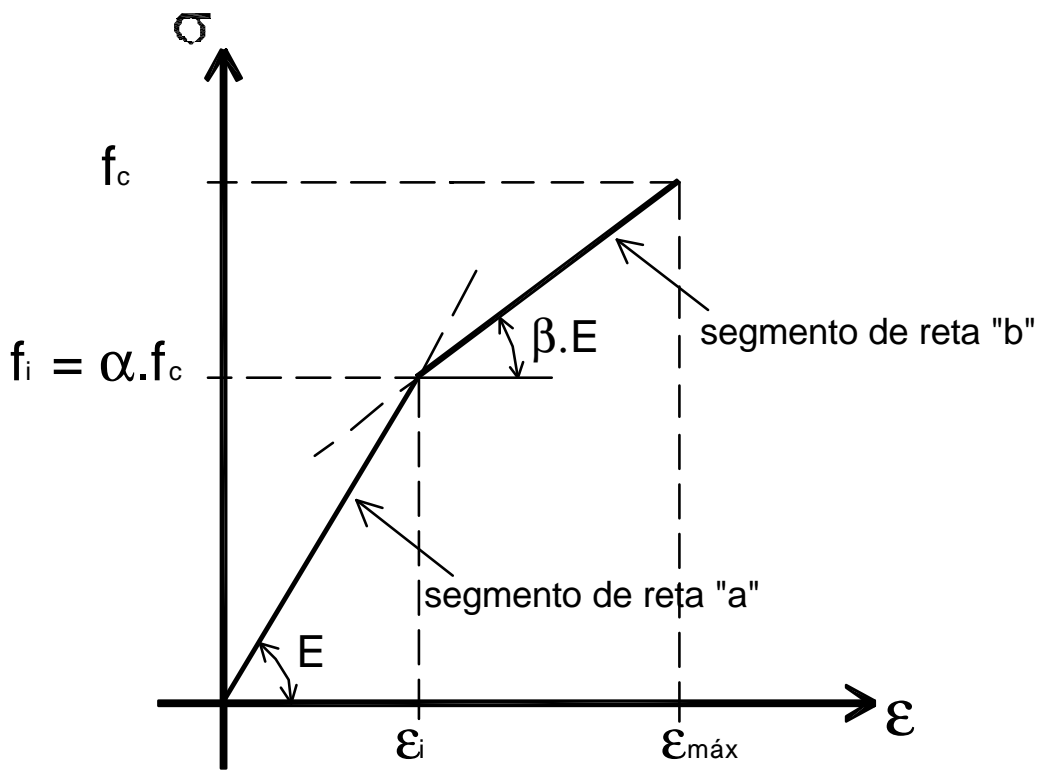

Figura 5.14 - Relação tensão x deformação proposta para o concreto de pós reativos

A relação constitutiva pode ser representada algebricamente da seguinte maneira:

- as equações das retas são: $\left\{\begin{array}{l}\text { segmentode reta" } a " \rightarrow \sigma=E \cdot \varepsilon \\ \text { segmentode reta" } b " \rightarrow \sigma=\beta \cdot E \cdot \varepsilon+\text { const. }\end{array}\right.$

A interseção dos segmentos de retas "a" e "b" ocorre no ponto de transição $\left(f_{i}\right.$, $\left.\varepsilon_{i}\right)$. Assim, igualando as equações 5.4 , e fazendo " $\varepsilon=\varepsilon_{i}$ ", temos:

$$
E \cdot \varepsilon_{i}=\beta \cdot E \cdot \varepsilon_{i}+\text { const } . \Rightarrow \text { const } .=E \cdot \varepsilon_{i}-\beta \cdot E \cdot \varepsilon_{i} \Rightarrow \text { const. }=E \cdot \varepsilon_{i}(1-\beta)
$$

Como $f_{\mathrm{i}}=E \cdot \varepsilon_{i}$, então o valor da constante será igual a:

$$
\text { const. }=\sigma_{i} \cdot(1-\beta)
$$

Logo, a relação constitutiva para o concreto de pós reativos pode ser representada pela equação 5.6.

$$
\boldsymbol{\sigma}=\boldsymbol{\beta} \cdot E \cdot \boldsymbol{\varepsilon}+f_{\mathrm{i}} \cdot(1-\boldsymbol{\beta}) \text { onde } \begin{cases}\boldsymbol{\beta}=1 & \text { se } \boldsymbol{\sigma} \leq f_{\mathrm{i}} \\ \boldsymbol{\beta}=0,03 \cdot V_{f}+0,8 & \text { se } \boldsymbol{\sigma}>f_{\mathrm{i}}\end{cases}
$$

O ponto de transição é determinado em função da tensão de ruptura $\left(f_{c}\right)$ e do volume de fibras $\left(V_{f}\right)$, de acordo com as equações 5.1 e 5.2 descritas anteriormente, e repetidas pela equação 5.7 .

$$
\begin{aligned}
& f_{i}=\boldsymbol{\alpha} \cdot f_{c} \\
& \alpha=-0,0086 \cdot \mathrm{V}_{\mathrm{f}}^{4}+0,0988 \cdot \mathrm{V}_{\mathrm{f}}^{3}-0,3561 \cdot \mathrm{V}_{\mathrm{f}}^{2}+0,3609 \cdot \mathrm{V}_{\mathrm{f}}+0,6764
\end{aligned}
$$


onde: $\quad f_{i}=$ tensão no ponto de transição;

$f_{c}=$ resistência de ruptura;

$\alpha=$ coeficiente de redução da tensão de ruptura;

$V_{f}=$ taxa de fibras em volume, multiplicada por 100.

\subsection{1- Verificação do modelo proposto para a relação constitutiva}

Conforme comentado nos capítulos 1 e 2, a única pesquisa que apresentou uma relação constitutiva para o CPR foi a de BEHLOUL (1995), onde se propôs uma lei do comportamento baseada em ensaios realizados por DUGAT et al. (1995), o qual estudou as propriedades mecânicas do CPR. Esse comportamento foi utilizado e comprovado por ADELINE \& BHELOUL (1996) em ensaios de vigas protendidas.

A lei do comportamento do CPR desenvolvida em BEHLOUL (1995), baseada nas propriedades mecânicas medidas em corpos-de-prova, necessita dos seguintes parâmetros: módulo de elasticidade $\mathrm{E}$; resistência à compressão $f_{c}$; e módulo de ruptura $f_{f}$. Assim, o concreto de pós reativos foi definido, segundo BEHLOUL (1995), da seguinte maneira:

- $\quad$ na compressão: uma curva bilinear, na qual a primeira parte tem inclinação igual a $E$, e se mantém até $40 \%$ da resistência à compressão $f_{c}$, e a segunda parte corresponde ao trecho de $40 \%$ de $f_{c}$ até $f_{c}$, com uma inclinação de 0,8E.

- $\quad$ na tração: uma parte linear até $f_{f} / 4,32$, com inclinação igual a 0,9E, e uma parte pós-pico com uma forma cúbica.

Comparando a proposta desta pesquisa, equação 5.6, com o modelo indicado por BEHLOUL (1995), percebe-se que eles apresentam forma semelhante no tocante ao comportamento bilinear, mostrando que este é uma propriedade de materiais a base de cimento Portland com altíssima resistência àcompressão.

A fim de comparar os dois modelos teóricos com os resultados experimentais obtidos nesta pesquisa, escolheu-se um diagrama tensão $\mathrm{x}$ deformação de cada série, ou seja, com diferentes quantidades de fibras, e montaram-se os gráficos conforme mostra a figura 5.15 .

Analisando os gráficos da figura 5.15, percebe-se que o modelo proposto neste trabalho, equação 5.6, representa com precisão os resultados experimentais, para qualquer taxa de fibras utilizada na dosagem. O modelo proposto por BEHLOUL (1995), que não considera a quantidade de fibras contida no concreto, tornando-se assim mais simples, apresentou resultados próximos dos experimentais, e do ponto de vista da análise estrutural, pode ser considerado a favor da segurança. 


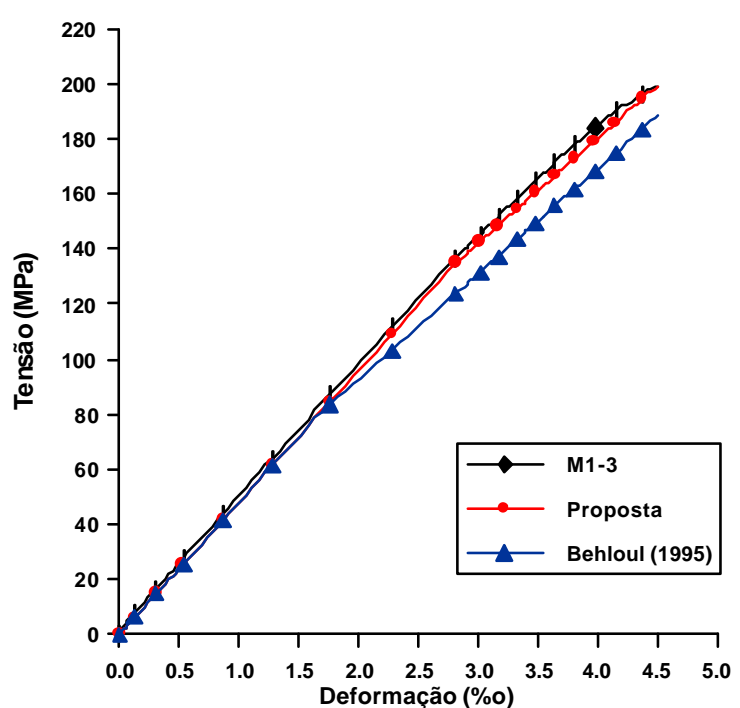

(a) [sem fibras]

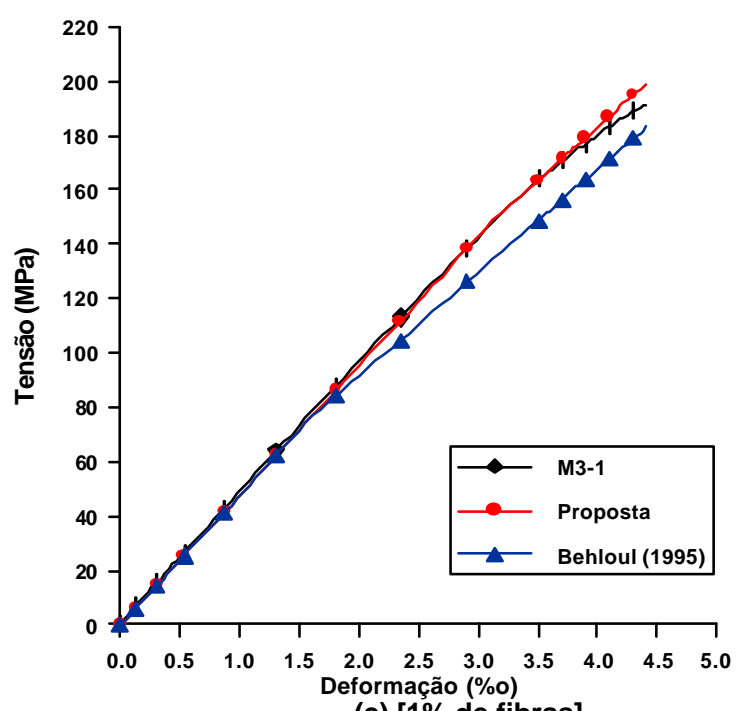

(c) $[1 \%$ de fibras $]$

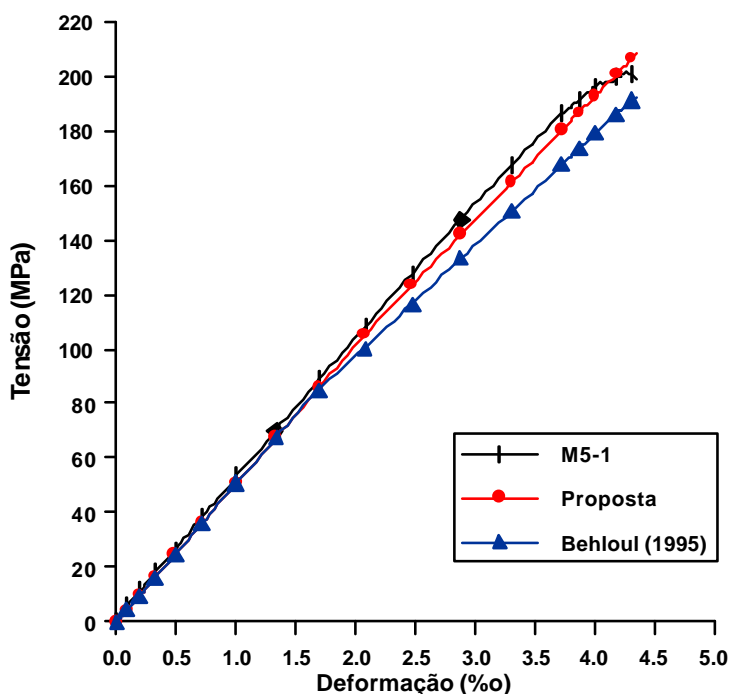

(e) [3\% de fibras]

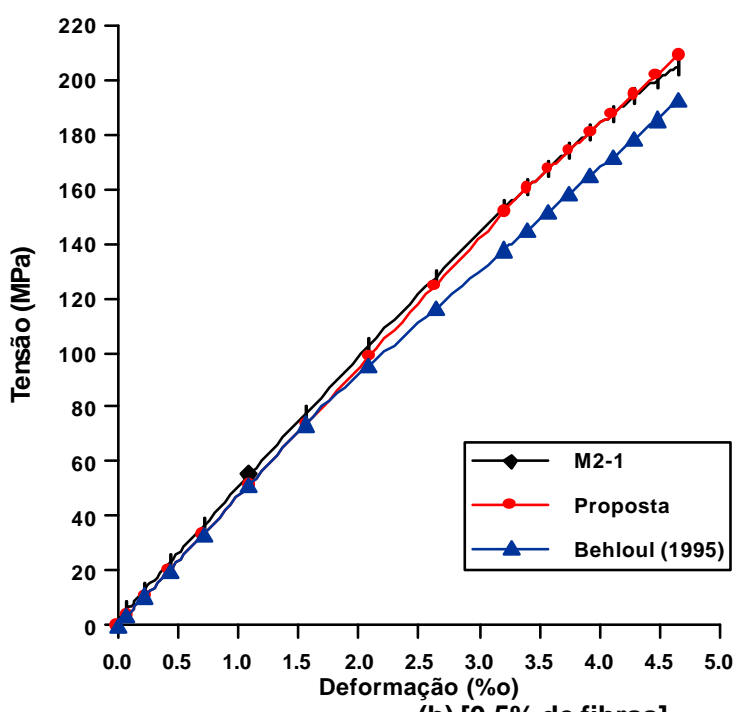

(b) $[0,5 \%$ de fibras]

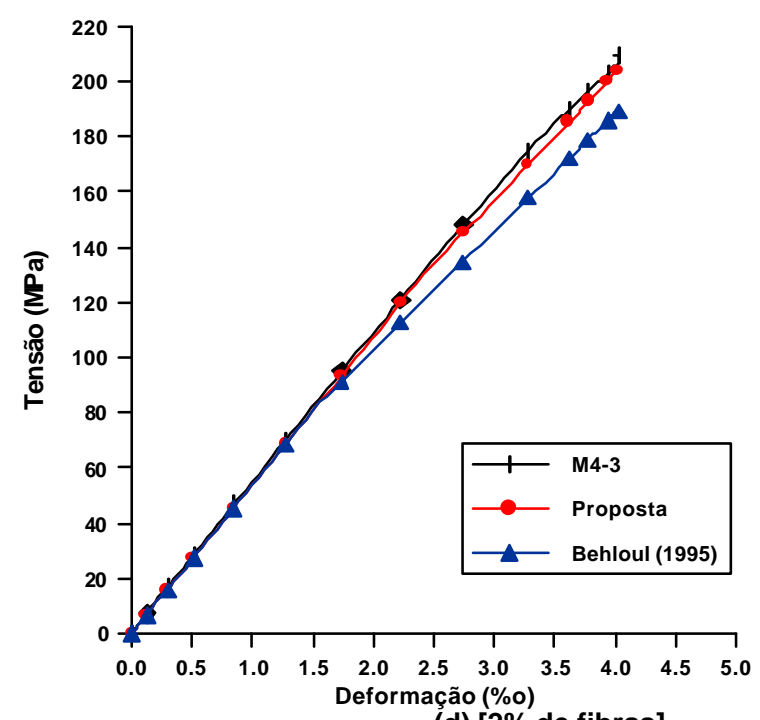

(d) $[2 \%$ de fibras $]$

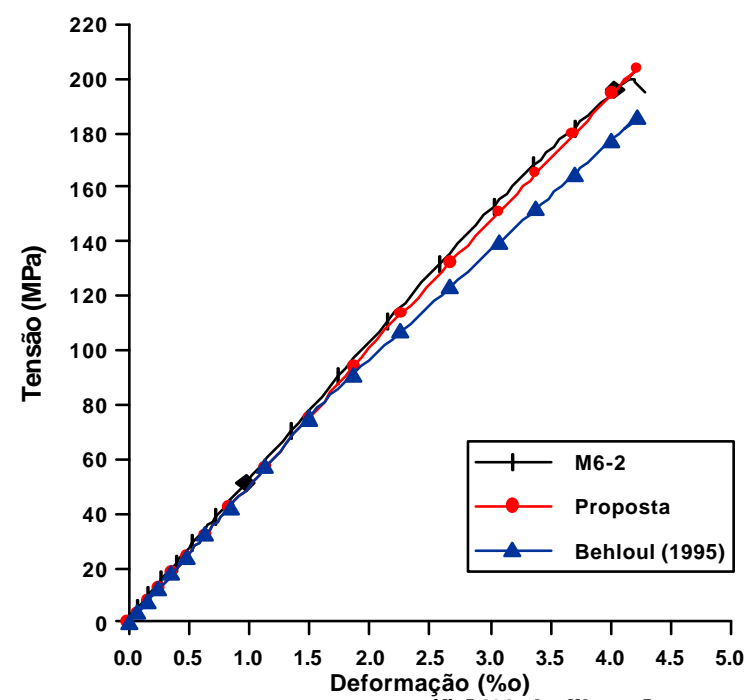

(f) $[4 \%$ de fibras]

Figura 5.15 - Comparação entre a relação tensão x deformação proposta, a sugerida por Behloul et al. (1995), e os resultados experimentais: (a) sem fibras; (b) $0,5 \%$ de fibras; (c) $1 \%$ de fibras; (d) $2 \%$ de fibras; (e) $3 \%$ de fibras; (f) $4 \%$ de fibras. 
Com esta análise, conclui-se que o modelo matemático sugerido pela equação 5.6, pode ser utilizado para representar o comportamento tensão $x$ deformação para concretos de pós reativos, com resistência àcompressão próxima de 200MPa, e taxas de fibras entre $0 \%$ e $4 \%$ do volume. Lembrando que para efeito de dimensionamento, deve-se adotar uma margem de segurança, cujo valor não foi analisado nesta pesquisa.

\section{6- Análise do Comportamento à Flexão}

O comportamento à flexão do concreto de pós reativos foi analisado segundo ensaios de flexão em 4 pontos, realizados em prismas de $50 \mathrm{~mm} \times 50 \mathrm{~mm} \times 340 \mathrm{~mm}$. A moldagem dos modelos, sistema de aplicação de força, vínculos, instrumentação e procedimentos de ensaios, foram descritos nos itens 4.3.2 e 4.6.3 do capítulo anterior.

O programa de ensaio consistiu em analisar seis série, já descritas anteriormente, com taxas de fibras entre $0 \%$ e $4 \%$ do volume. Para cada série foram ensaiados 3 modelos com idade de 28 dias, conforme tabela 4.3, e registrado a força aplicada e respectivo deslocamento vertical da seção central, assim como, as deformações nas superfícies superior e inferior do modelo. O intervalo de leitura dos dados era de 0,5 segundo.

Os deslocamentos eram medidos com auxílio do dispositivo de Bernier, onde era acoplado um transdutor de deslocamento, e as deformações eram obtidas por meio de extensômetros elétricos colados nas superfícies dos modelos, como já explicado no item 4.3.2.2.

A resistência à tração na flexão $\left(f_{f}\right)$ foi calculada utilizando as equações da teoria da Resistência dos Materiais, em que a resistência máxima é determinada segundo a equação 5.8 .

$$
f_{f}=\frac{F \cdot L}{b \cdot h^{2}}
$$

onde: $\quad f_{f}=$ resistência àflexão;

$F=$ força máxima medida;

$L=$ comprimento do prisma;

$b=$ dimensão da base da seção transversal do prisma;

$h=$ altura da base da seção transversal do prisma. 


\subsection{1- Influência das fibras na resistência à tração na flexão}

De acordo com a força máxima medida durante os ensaios de flexão nos prismas, calculou-se a resistência àflexão $\left(f_{f}\right)$ para cada modelo, utilizando a equação 5.7. Os resultados da média dos valores de cada série são mostrados na figura 5.16.

Analisando a figura 5.16, verifica-se que quanto maior a quantidade de fibras no concreto, maior a resistência à flexão dos modelos. A taxa de $4 \%$ de fibras praticamente triplicou a resistência àflexão, se comparada com o valor obtido na série sem fibras.

BEHLOUL et al. (1996) realizou ensaios de flexão de 3 pontos em CPR com resistência à compressão próxima de 200MPa. Neste estudo concluiu-se que existe uma taxa crítica de fibras ente $0,5 \%$ e $1 \%$, a partir do qual a resistência à flexão começava a ser influenciada.

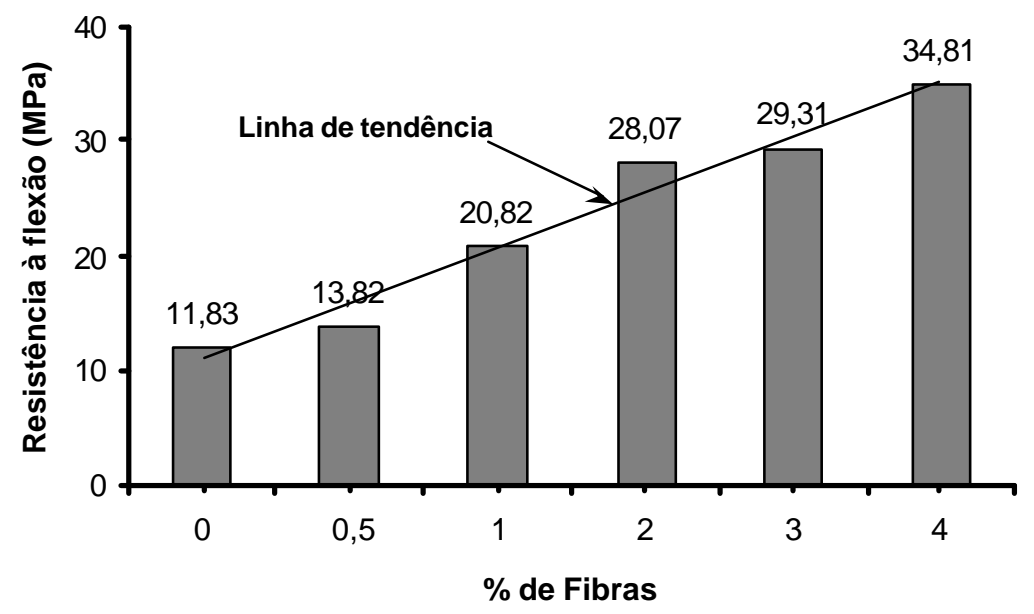

Figura 5.16 - Influência do volume de fibras na resistência à tração na flexão do CPR

Analisando o comportamento da resistência àflexão na figura 5.16, percebe-se que as fibras só começaram a influenciar a resistência àflexão a partir da taxa de 1\%, o que vem confirmar os estudos de BEHLOUL et al. (1996).

Assim, seguindo a linha de tendência de crescimento da resistência à flexão com o aumento do volume de fibras, pode-se propor uma relação linear entre a resistência àflexão e a taxa de fibras da mistura. Essa relação pode ser representada em função da resistência àflexão $\left(f_{f}\right)$ em concretos sem fibras, e do volume de fibras $\left(V_{f}\right)$, pela equação $(5.9)$.

$$
f_{f}=f_{f 1}+5,76 \cdot V_{f}
$$

onde: $\mathrm{f}_{f} \quad=$ resistência àflexão do concreto com fibras (ensaio à4 pontos);

$f_{f 1}=$ resistência àflexão do concreto sem fibras (ensaio à 4 pontos);

$V_{f}=$ taxa de fibras em volume, multiplicado por 100; 


\subsection{2- Análise do comportamento força $x$ deslocamento}

As relações força $\mathrm{x}$ deslocamento da seção central de cada modelo, são representadas em gráficos, onde a força é marcada no eixo das ordenadas em "kN", e os deslocamento no eixo das abscissa em "mm".

Os modelos da série M1, denominados M1-1, M1-2, M1-3, cuja dosagem não continha fibras metálicas, apresentaram comportamento muito frágil e rígido, atingindo a ruptura no aparecimento da primeira fissura na borda inferior dos modelos, provenientes de tensões de tração naquela região. Por causa da grande fragilidade e rigidez do material, não foi possível medir com precisão os deslocamento durante o ensaio.

Conforme comentado no item 4.6.3.1, o modelo M1-2 foi danificado por causa dos problemas ocorridos no preparo do ensaio, sendo assim, desconsiderado neste estudo.

Com a força máxima atingida nos ensaios dos modelos, calcularam-se a resistência àflexão do material, para ensaios em 4 pontos, segundo a equação 5.8 , e os resultados são mostrados na tabela 5.13. O deslocamento não foi medido nos ensaios da série M1.

Tabela 5.13 - Resultados dos modelos da série M1

\begin{tabular}{c|c|c}
\hline Modelo & $\begin{array}{c}\text { Força máxima } \\
(\mathbf{k N})\end{array}$ & $\begin{array}{c}\text { Resistência à flexão } \\
(\mathbf{M P a})\end{array}$ \\
\hline $\mathbf{M} 1-1$ & 5,237 & 12,57 \\
\hline $\mathbf{M} 1-3$ & 4,618 & 11,08 \\
\hline \multicolumn{2}{|c|}{ Média } & $\mathbf{1 1 , 8 3}$ \\
\hline
\end{tabular}

Os modelos da série $\mathrm{M} 2$, cuja dosagem continha $0,5 \%$ do volume em fibras metálicas, também apresentaram comportamento muito frágil e rígido, atingindo a ruptura, por causa das tensões de tração, no aparecimento da primeira fissura na borda inferior.

Os três modelos, denominados M2-1, M2-2, M2-3, atingiram resistência à flexão, conforme mostrado na tabela 5.14.

Tabela 5.14 - Resultados dos modelos da série M2

\begin{tabular}{c|c|c}
\hline Modelo & $\begin{array}{c}\text { Força máxima } \\
(\mathbf{k N})\end{array}$ & $\begin{array}{c}\text { Resistência à flexão } \\
(\mathbf{M P a})\end{array}$ \\
\hline $\mathbf{M} 2-1$ & 6,022 & 14,45 \\
\hline $\mathbf{M} 2-2$ & 5,204 & 12,49 \\
\hline $\mathbf{M} 2-3$ & 5,924 & 14,22 \\
\hline \multicolumn{2}{c}{ Média } & $\mathbf{1 3 , 8 2}$ \\
\hline
\end{tabular}

A partir dos resultados dos ensaios pôde-se montar os gráficos força $x$ deslocamento, que são mostrados na figura 5.17. Analisando esses gráficos, nota-se 
que os modelos apresentaram comportamento muito rígido até a ruptura, onde a partir deste ponto ocorreu perda brusca na rigidez, e os deslocamentos verticais começaram a aparecer de forma significativa. Após a perda de rigidez, o qual caracterizou a ruptura, os modelos apresentaram recuperação parcial da capacidade resistente, o que pode ser atribuído a fibras contidas no material, que evitaram o rompimento da seção e distribuíram as tensões de tração na borda inferior através das fissuras.

Com taxa de $1 \%$ de fibras, os modelos da série M3, denominados M3-1, M3-2, M3-3, apresentaram comportamento menos rígido, que os das séries M1 e M2, e mais dúctil. Os três modelos atingiram resistência à flexão conforme mostrado na tabela 5.15 .

Tabela 5.15 - Resultados dos modelos da série M3

\begin{tabular}{c|c|c}
\hline Modelo & $\begin{array}{c}\text { Força máxima } \\
\text { (kN) }\end{array}$ & $\begin{array}{c}\text { Resistência à flexão } \\
\text { (MPa) }\end{array}$ \\
\hline M3-1 & 9,294 & 22,31 \\
\hline M3-2 & 9,291 & 22,30 \\
\hline M3-3 & 7,441 & 17,86 \\
\hline \multicolumn{2}{|c}{ Média } & $\mathbf{2 0 , 8 2}$ \\
\hline
\end{tabular}

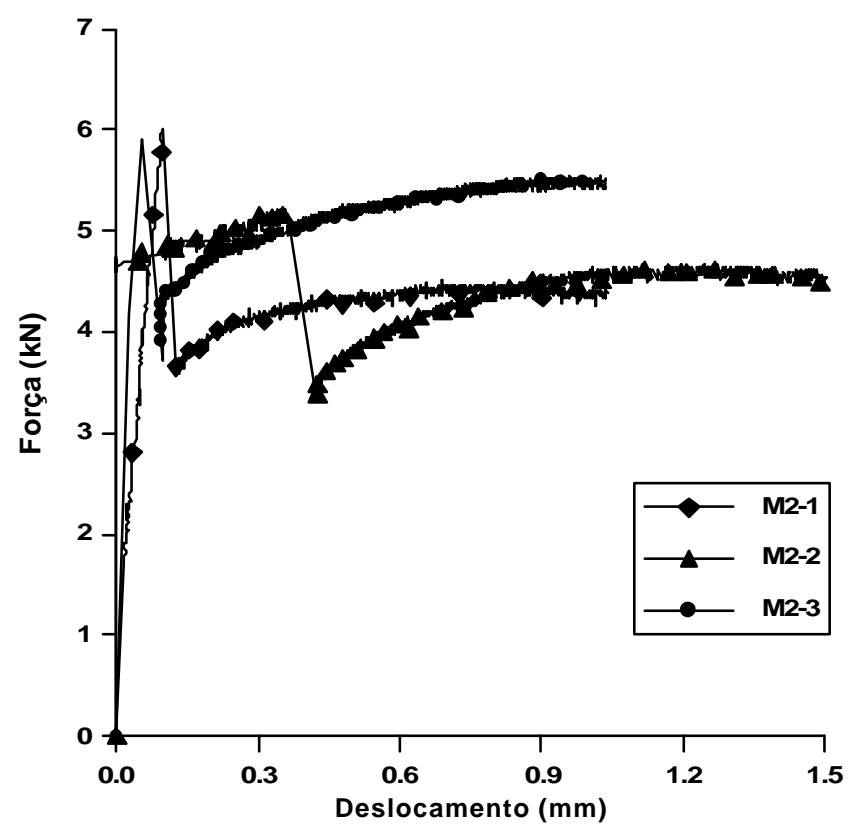

Figura 5.17 - Relação força $x$ deslocamento para os modelos da série M2

Os gráficos força $x$ deslocamento para os modelos da série M3 são mostrados na figura 5.18, onde se notou que os modelos apresentaram comportamento menos rígido, que os das séries anteriores, até o aparecimento das primeiras fissuras, com registros de deslocamentos próximos de $0,2 \mathrm{~mm}$. A partir deste ponto ocorreu perda brusca na rigidez, seguida de crescimento dos deslocamentos verticais. Entretanto, os modelos apresentaram aumento na capacidade resistente, que ocorreu de forma 
dúctil. Este fato pode ser atribuído a fibras contidas no material, que distribuíram as tensões de tração na borda inferior através das fissuras.

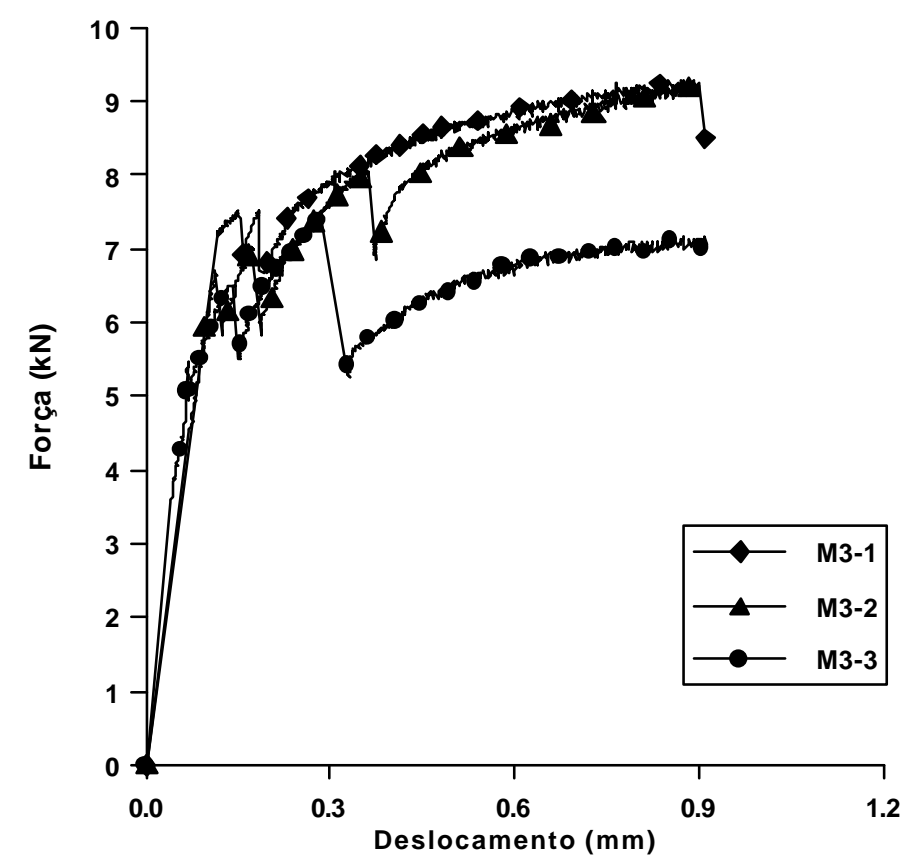

Figura 5.18 - Relação força x deslocamento para os modelos da série M3

Os modelos da série M4, com taxa de $2 \%$ de fibras, apresentaram comportamento mais dúctil que os modelos das séries anteriores. Os três modelos, denominados M4-1, M4-2 e M4-3, atingiram resistência àflexão conforme mostrado na tabela 5.16 .

Tabela 5.16 - Resultados dos modelos da série M4

\begin{tabular}{c|c|c}
\hline Modelo & $\begin{array}{c}\text { Força máxima } \\
(\mathbf{k N})\end{array}$ & $\begin{array}{c}\text { Resistência à flexão } \\
(\mathbf{M P a})\end{array}$ \\
\hline M4-1 & 12,962 & 31,11 \\
\hline M4-2 & 10,777 & 25,86 \\
\hline M4-3 & 11,406 & 27,37 \\
\hline \multicolumn{2}{|c|}{ Média } & $\mathbf{2 8 , 0 7}$ \\
\hline
\end{tabular}

A figura 5,19 apresenta os gráficos força $x$ deslocamento para os modelos da série $M 4$, onde se percebeu que estes não demonstraram perda brusca de resistência quando surgiram as primeiras fissuras, apresentando assim, comportamento dúctil.

Esse comportamento é atribuído a grande quantidade de fibras contida no concreto, fazendo com que haja uma maior transferência de tensões entre as fissuras formadas, evitando a perda de resistência e aumentando a capacidade resistente à flexão do modelo. 


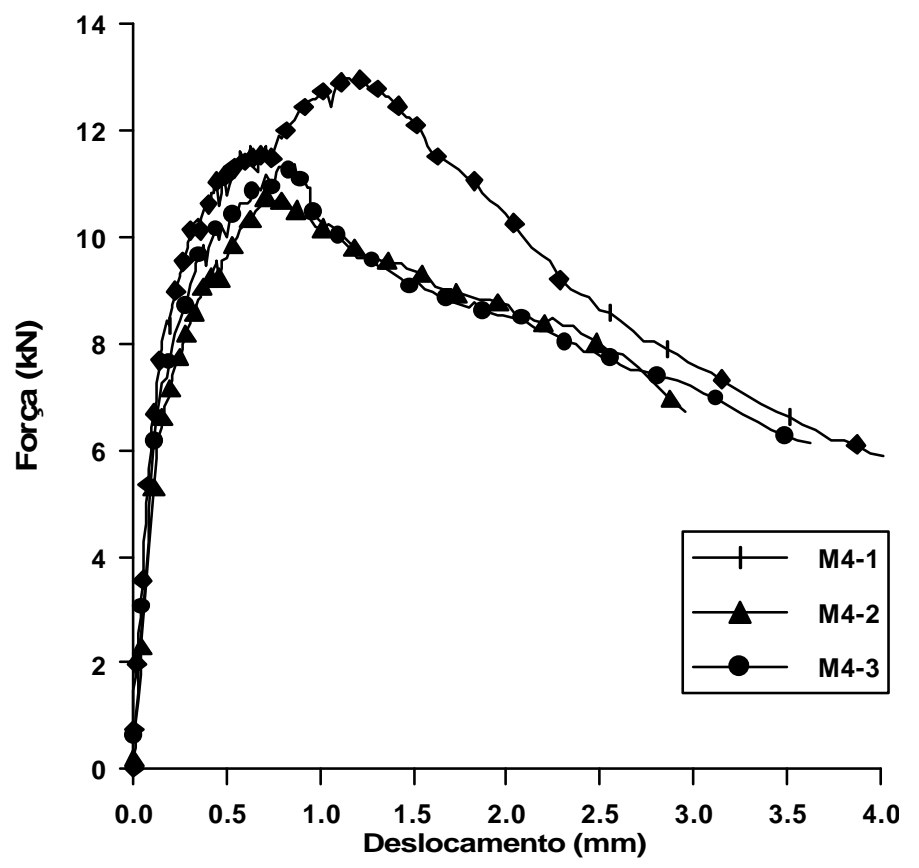

Figura 5.19 - Relação força $x$ deslocamento para os modelos da série M4

A série M5 continha em sua dosagem $3 \%$ do volume em fibras, e os modelos M5-1, M5-2 e M5-3, apresentaram comportamento dúctil, porém, com maior dispersão dos valores para a resistência àflexão, conforme mostra a tabela 5.17.

Os gráficos força $x$ deslocamento obtidos com os ensaios dos modelos da série M5, são mostrados na figura 5.20, onde se observa que os modelos desta série também não demonstraram perda brusca de resistência quando surgiram as primeiras fissuras, apresentando assim, comportamento dúctil, com ganho de capacidade resistente a flexão, semelhante ao comportamento da série M4.

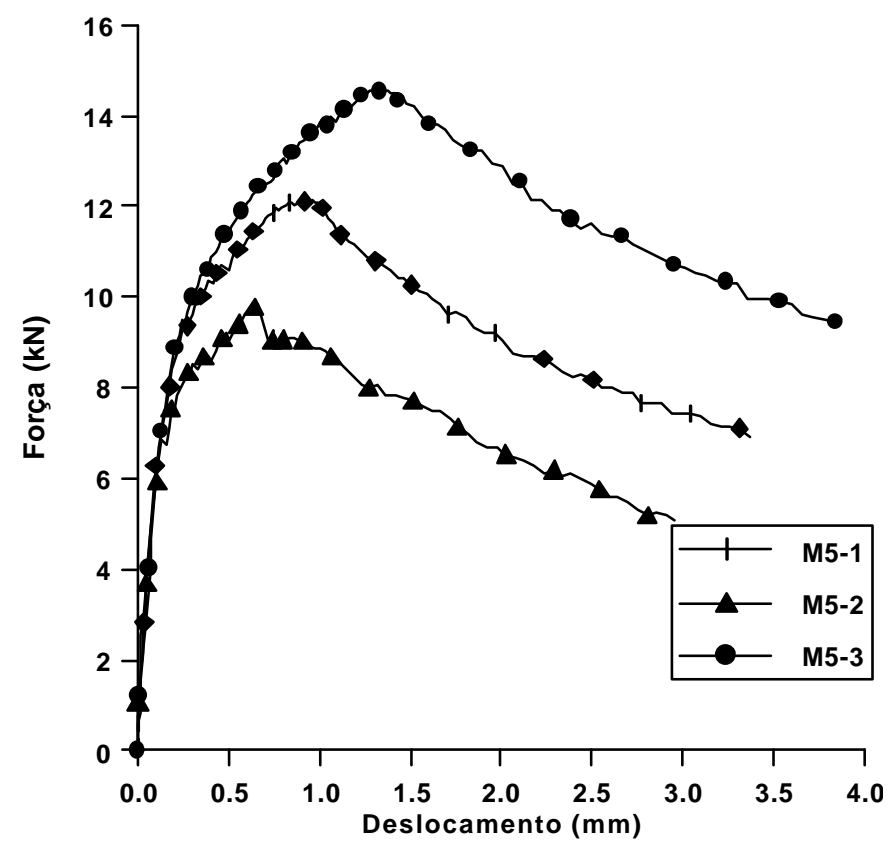

Figura 5.20 - Relação força $x$ deslocamento para os modelos da série M5 
Tabela 5.17 - Resultados dos modelos da série M5

\begin{tabular}{c|c|c}
\hline Modelo & $\begin{array}{c}\text { Força máxima } \\
(\mathbf{k N})\end{array}$ & $\begin{array}{c}\text { Resistência à flexão } \\
\text { (MPa) }\end{array}$ \\
\hline M5-1 & 12,175 & 29,22 \\
\hline M5-2 & 9,871 & 23,69 \\
\hline M5-3 & 14,592 & 35,02 \\
\hline \multicolumn{2}{|c|}{ Média } & $\mathbf{2 9 , 3 1}$ \\
\hline
\end{tabular}

A série M6 continha em sua dosagem 4\% do volume em fibras, e os modelos M6-1, M6-2 e M6-3, apresentaram comportamento dúctil, porém, com maior dispersão dos valores para a resistência àflexão, conforme mostra a tabela 5.18.

Tabela 5.18 - Resultados dos modelos da série M6

\begin{tabular}{c|c|c}
\hline Modelo & $\begin{array}{c}\text { Força máxima } \\
(\mathbf{k N})\end{array}$ & $\begin{array}{c}\text { Resistência à flexão } \\
(\mathbf{M P a})\end{array}$ \\
\hline M6-1 & 15,825 & 37,98 \\
\hline M6-2 & 13,594 & 32,98 \\
\hline M6-3 & 14,195 & 34,07 \\
\hline \multicolumn{2}{|c|}{ Média } & $\mathbf{3 4 , 8 1}$ \\
\hline
\end{tabular}

Os gráficos força $x$ deslocamento obtidos com os ensaios dos modelos da série M6, são mostrados na figura 5.21 , onde se observa que os modelos desta série também não demonstraram perda brusca de resistência quando surgiram as primeiras fissuras, apresentando assim comportamento dúctil, com ganho de capacidade resistente a flexão, semelhante ao comportamento das séries M4 e M5.

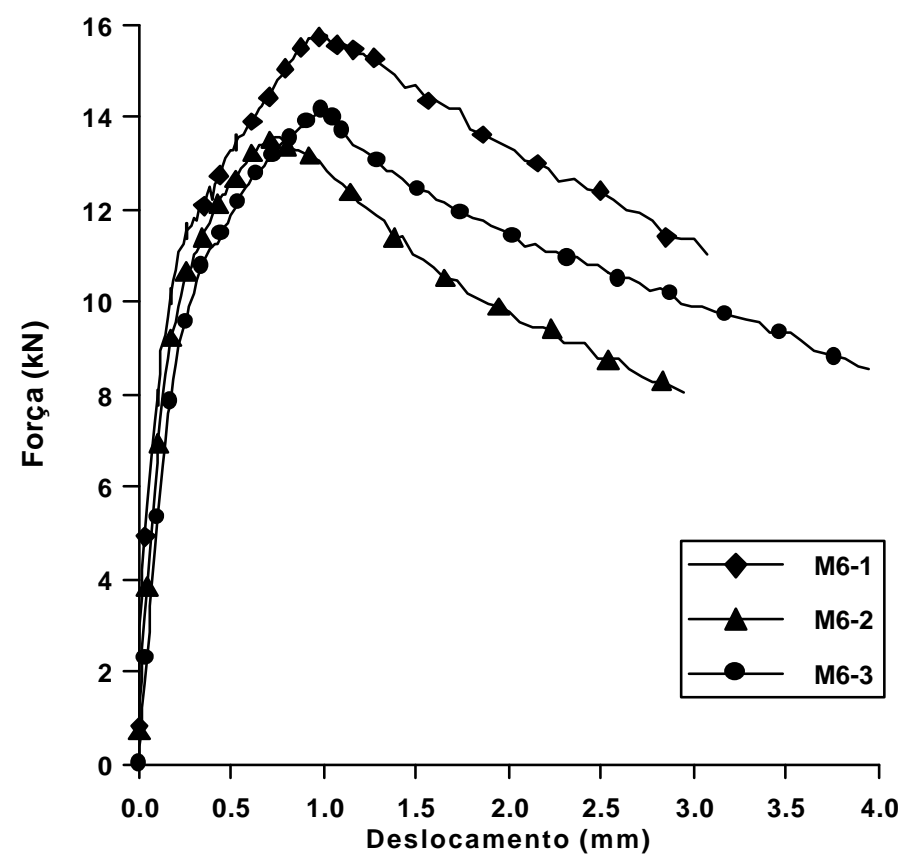

Figura 5.21 - Relação força $x$ deslocamento para os modelos da série M6 


\subsection{3- Análise das deformações nos ensaios de flexão em 4 pontos}

Nos ensaios de flexão, a região central dos modelos eram solicitadas a flexão pura, atuando apenas tensões normais de tração nas fibras inferiores, e de compressão nas superiores. Essas tensões provocavam deformações, que foram medidas por meio de extensômetros elétricos colados nas superfícies superior e inferior dos modelos.

Para analisar o comportamento dessas deformações durante o processo de solicitação àflexão pura, compararam-se as deformações de tração (fibra inferior) e de compressão (fibra superior). Procurou-se determinar a relação entre as duas deformações por meio de um gráfico, onde colocou-se as deformações de tração no eixos das abscissas, e as de compressão no eixos das ordenadas, e observou-se até que ponto as duas deformações apresentavam propriedades semelhantes.

Como exemplo, a figura 5.22 mostra o gráfico feito para o modelo M6-3, onde verifica-se que a deformação elástica linear do material deixa de existir a partir de um determinado ponto da curva, definido no gráfico como "ponto D". Logo, por esta análise, pode-se identificar a deformação máxima na tração que o concreto pode atingir, sem ultrapassar o limite elástico.

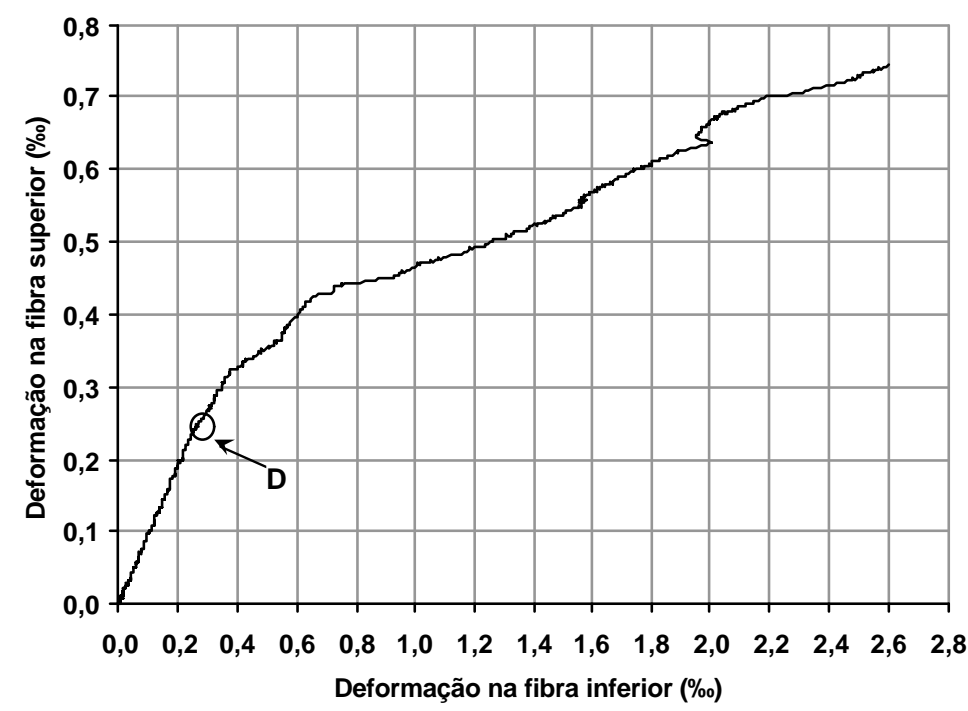

Figura 5.22 - Comparação das deformações na tração e na compressão em ensaios à flexão em 4 pontos. Modelo M6-3.

Assim, analisaram-se todos os modelos ensaiados, montando-se gráficos semelhantes ao apresentado na figura 5.22, e identificou-se as deformações máximas na tração correspondente aos limites elásticos para cada modelo. Os resultados são mostrados na tabela 5.19 . 
Tabela 5.19 - Deformações para o limite elástico na tração do concreto de pós reativos

\begin{tabular}{|c|c|c|c|}
\hline Modelos & $\begin{array}{c}\text { Deformação de } \\
\text { tração (\%o) }\end{array}$ & $\begin{array}{l}\text { Deformação de } \\
\text { compressão (\%) }\end{array}$ & $\begin{array}{c}\text { Média } \\
(\% \circ)\end{array}$ \\
\hline M1-1 & --- & --- & --- \\
\hline M1-3 & 0,226 & 0,217 & 0,222 \\
\hline \multicolumn{3}{|c|}{ Deformações máximas na tração para $0 \%$ de fibras } & 0,222 \\
\hline M2-1 & 0,284 & 0,281 & 0,283 \\
\hline M2-2 & 0,235 & 0,242 & 0,239 \\
\hline M2-3 & 0,290 & 0,273 & 0,282 \\
\hline \multicolumn{3}{|c|}{ Deformações máximas na tração para $0,5 \%$ de fibras } & 0,268 \\
\hline M3-1 & 0,283 & 0,293 & 0,288 \\
\hline M3-2 & 0,322 & 0,315 & 0,319 \\
\hline M3-3 & 0,266 & 0,258 & 0,262 \\
\hline \multicolumn{3}{|c|}{ Deformações máximas na tração para $1 \%$ de fibras } & 0,290 \\
\hline M4-1 & 0,262 & 0,248 & 0,255 \\
\hline M4-2 & 0,247 & 0,243 & 0,245 \\
\hline M4-3 & 0,272 & 0,261 & 0,267 \\
\hline \multicolumn{3}{|c|}{ Deformações máximas na tração para $2 \%$ de fibras } & 0,256 \\
\hline M5-1 & 0,282 & 0,282 & 0,282 \\
\hline M5-2 & 0,273 & 0,270 & 0,272 \\
\hline M5-3 & 0,291 & 0,290 & 0,291 \\
\hline \multicolumn{3}{|c|}{ Deformações máximas na tração para 3\% de fibras } & 0,282 \\
\hline M6-1 & 0,383 & 0,323 & 0,353 \\
\hline M6-2 & 0,310 & 0,310 & 0,310 \\
\hline M6-3 & 0,239 & 0,241 & 0,240 \\
\hline \multicolumn{3}{|c|}{ Deformações máximas na tração para $4 \%$ de fibras } & 0,301 \\
\hline
\end{tabular}

Observa-se que o aumento da quantidade de fibras no material provoca uma pequena variação no valor da deformação máxima para o limite elástico na tração, conforme mostra a figura 5.23. Assim, pode-se adotar como o limite elástico para deformações de tração do concreto de pós reativos estudado, o valor médio de $0,28 \%$.

Estudo semelhante feito por DUGAT et al. (1995), constatou que o limite elástico, para a deformação na tração de concretos de pós reativos com fibras, foi de $0,33 \%$, mostrando que o concreto desenvolvido neste trabalho se assemelha aos utilizados em pesquisas já desenvolvidas.

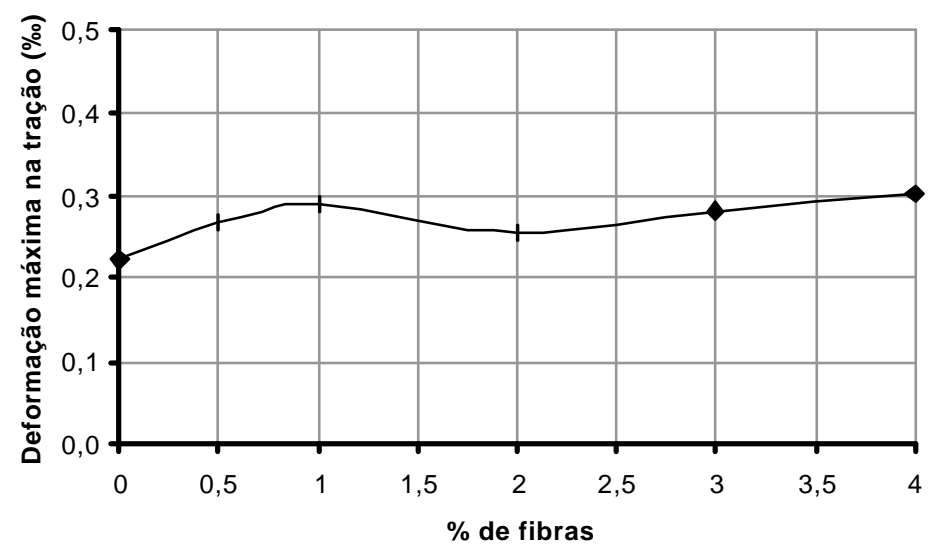

Figura 5.23 - Relação entre a deformação máxima na tração e o volume de fibras 


\section{Considerações Finais}

A partir dos resultados dos ensaios de compressão axial e flexão em 4 pontos, pôde-se analisar as propriedades mecânicas do concreto de pós reativo, observando o comportamento da resistência à compressão ao longo do tempo; a influência das fibras na resistência àcompressão; a relação tensão $x$ deformação para o concreto de pós reativos; o módulo de deformação longitudinal; as deformações específicas na compressão; as deformações máximas na tração; a influência das fibras na resistência àtração na flexão; e o comportamento força x deslocamento.

A resistência à compressão média foi de $200 \mathrm{MPa}$ e se estabilizou a partir dos 28 dias de idade para o concreto sem fibra, já os que continham fibras, a estabilidade na resistência ocorreu aos 7 dias. Onde se concluiu que a adição de fibras, juntamente com a cura térmica, promovem aceleração no crescimento da resistência à compressão nas primeiras idades.

As fibras provocaram pequeno crescimento da resistência àcompressão, até a taxa de $3 \%$, onde a partir deste ponto, houve decréscimo na resistência.

A relação tensão $x$ deformação para 0 concreto de pós reativos estudado, apresentou comportamento bilinear. O ponto de transição entre os dois trechos retilíneos, foi definido por um coeficiente de redução da resistência de ruptura, denominado " $\alpha$ ", e este coeficiente foi determinado de acordo com os dados experimentais.

O coeficiente de proporcionalidade entre a tensão e a deformação para cada trecho retilíneo, foi determinado de acordo com as análises realizadas a respeito do comportamento do módulo de elasticidade do material. A relação entre o módulo de

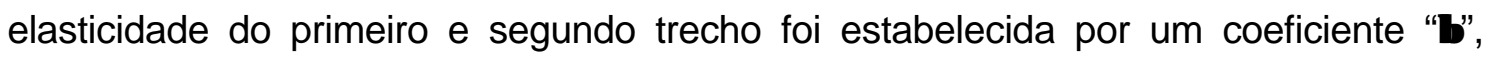
definido com base nos resultados experimentais.

A deformação específica máxima na compressão, para o concreto de pós reativos estudado, foi definida como o valor médio de 4,3\%。. Entretanto, o limite elástico para as deformações de tração, foi de 0,28\%.

A partir das análises, foi proposta uma relação constitutiva para compressão, que pode ser utilizada em concreto de pós reativos, com resistência à compressão próximo de $200 \mathrm{MPa}$ e taxa de fibras até $4 \%$ do volume. A relação tensão $x$ deformação proposta, foi representada pelas equações 5.6 e 5.7.

$\mathrm{Na}$ análise do comportamento àflexão do concreto de pós reativos, observouse que taxas de fibras a partir de $2 \%$ promovem maior ductilidade ao material, quando solicitados a flexão pura, sem perdas bruscas de resistência. O aumento da 
quantidade de fibras também provocou crescimento da resistência àtração na flexão do material, e esse efeito só foi constatado com taxas de fibras a partir de $1 \%$.

Essas análises forneceram parâmetros importantes para o conhecimento do concreto de pós reativos, quando este for submetido a solicitações normais e de flexão. E os parâmetros definidos neste estudo foram sobre um material desenvolvido com tecnologia própria, e materiais disponíveis na região, o que favorece a continuidade da pesquisa com novos estudos sobre aplicações em estruturas em escala real e submetidas a esforços solicitantes. 


\section{Capítulo}

\section{ANÁLISE MICROESTRUTURAL DO CONCRETO DE PÓS REATIVOS}

Este apêndice apresenta um estudo sobre a microestrutura do concreto de pós reativos, onde se analisou a porosidade da matriz, além da morfologia e textura dos produtos hidratados formados no CPR. Para este estudo, utilizou-se os procedimento de "Porosimetria por Intrusão de Mercúrio" (PIM), e "Microscopia Eletrônica de Varredura" (MEV) associada a "Espectrografia por Dispersão de Energias" (EDS). 


\section{1- Microestrutura do Concreto}

Segundo MEHTA (1994), a microestrutura da pasta de cimento apresenta uma agregação de produtos pouco cristalinos (principalmente silicato de cálcio hidratado: C-S-H), cristais de etringita semelhantes a agulhas, grandes cristais de hidróxido de cálcio com morfologia de lâminas hexagonais, algumas partículas de clinquer não hidratadas, bulbos ocasionados por ar aprisionado e vazios capilares de vários tamanhos e formas.

A estrutura da pasta de cimento Portland endurecida, segundo MEHTA (1994), é composta basicamente de sólidos, vazios e água. Em sua microestrutura identificamse várias fases que não estão uniformemente distribuídas em tamanho e morfologia, como as fases sólidas, os diferentes tipos de vazios e a água.

As principais fases sólidas são quatro: silicato de cálcio hidratado (C-S-H); hidróxido de cálcio $(\mathrm{CH})$; sulfatoaluminato de cálcio e grãos de clínquer não hidratados.

Os vazios tem grande influência na propriedade da pasta e são formados por espaços interlamelares no $\mathrm{C}-\mathrm{S}-\mathrm{H}$, vazios capilares e bolhas de ar, formando o sistema poroso da matriz.

A água pode estar presente na pasta de várias formas, como água capilar, água adsorvida, água interlamelar e água quimicamente combinada.

O estudo da microestrutura do concreto vem sendo realizados por meios de várias técnicas e equipamentos modernos, dentre os quais se destacam o microscópio eletrônico de varredura (MEV), a ressonância nuclear magnética, a termogravimetria, a difratometria de Raios - X (DRX), e porosimetria.

\section{2- Análise da Microestrutura do Concreto de Pós reativos}

O concreto de pós reativos é um material, cuja sua microestrutura difere dos demais concretos conferindo, assim, elevadas resistências e durabilidade.

As técnicas utilizadas neste trabalho, para o estudo da microestrutura do concreto de pós reativos foram, a Porosimetria por Intrusão de Mercúrio (PIM) e Microscopia Eletrônica de Varredura (MEV) associada à Espectrografia por Dispersão de Energia (EDS).

\section{3- Porosimetria por Intrusão de Mercúrio}

A Porosimetria por Intrusão de Mercúrio (PIM) é uma das técnicas mais utilizadas para a análise das propriedades físicas de materiais porosos (concreto, cerâmica, etc.), fornecendo informações sobre a distribuição volumétrica de poros com 
dimensões entre $150 \mu \mathrm{m}$ e $0,003 \mu \mathrm{m}$. No entanto, segundo WHITTMORE \& HALSEY $(1983)^{3}$ apud SILVA (2000), o modelo empregado nos cálculos considera todos os poros de geometria cilíndrica, o que compromete a confiabilidade dos resultados quando as dimensões envolvidas são inferiores a $0,01 \mu \mathrm{m}$. Nesta faixa de poros, encontram-se os pequenos capilares, poros entre partículas de gel e poros de gel.

SILVA (2000) descreve que esse método é baseado no fato de que um líquido que não "molha" um sólido poroso só penetrará em seus poros sob a ação de pressão externa, sem a ação da capilaridade. O líquido, neste caso, é o mercúrio.

O tamanho equivalente dos poros preenchidos pelo mercúrio, admitindo os poros cilíndricos, pode ser associado àpressão aplicada pela equação 6.1 .

$$
d=-\frac{4 \cdot \gamma \cdot \cos (\boldsymbol{\theta})}{p}
$$

onde: $\mathrm{d}=$ diâmetro do poro;

$\gamma=$ energia superficial do líquido;

$\theta=$ ângulo de contato entre o mercúrio e a parede do poro;

p = pressão aplicada.

\subsection{1- Estudo do sistema de poros para o concreto de pós reativos}

A análise de porosimetria por intrusão de mercúrio foi realizada no Grupo de Crescimento de Cristais e Materiais Cerâmicos, do Departamento de Física e Ciências dos Materiais, Instituto de Física de São Carlos - USP, onde se utilizou o equipamento "Pore Sizer 9320 / Micromeritcs".

A pressão aplicada variou entre $4,4 \mathrm{kPa}$ e $200 \mathrm{MPa}$, o que possibilitou a análise dos poros com diâmetro entre $0,006 \mu \mathrm{m}$ e $100 \mu \mathrm{m}$, aproximadamente. A energia superficial do líquido $(\gamma)$ foi de $0,485 \mathrm{~N} / \mathrm{m}$, e o ângulo de contato entre o mercúrio e a parede do poro $(\theta)$ igual a $130^{\circ}$.

A amostra analisada foi retirada de corpo-de-prova de concreto de pós reativos, com idade de hidratação de 148 dias. O corte da amostra nas dimensões de $15 \mathrm{~mm} \times 15 \mathrm{~mm} \times 15 \mathrm{~mm}$, ocorreu com auxílio de serra diamantada, àbaixa velocidade. Em seguida, foi secada à vácuo com pressão de $60 \mathrm{~cm} . \mathrm{Hg}$ por 5 minutos, e levada à estufa, onde secou a $60^{\circ} \mathrm{C}$ por 24 horas.

Após a secagem, a amostra foi introduzida em um porta-amostra (penetrômetro), compatível com as dimensões das amostras, e submetida a um vácuo

\footnotetext{
${ }^{3}$ WHITTMORE, C. J.; HALSEY, G. D. (1983). Pore structure characterization by mercury porosimetry. In: Advances in Materials Characterization. Ed. David, R.; Rossington, R.; Condrate, C. A.; Snyder, R. L., p. 147-157, Plenum Publishing Corporation, New York.
} 
da ordem de $1,4 \mathrm{cmHg}$ a 2,0 cmHg. O preenchimento do penetrômetro com mercúrio foi realizado a baixa pressão da ordem de $0,17 \mathrm{MPa}$. A pressão do sistema foi gradativamente elevada por incrementos, e registrados os valores de pressão absoluta e de volume do mercúrio introduzido, até atingir a máxima pressão em torno de 200MPa. A pressão absoluta foi convertida, pelo uso da equação 6.1 apresentada, para diâmetro de poro aparente introduzido, sendo necessário adotar-se a energia superficial do líquido $(\gamma)$ e o ângulo de contato entre o mercúrio e a parede do poro $(\theta)$, conforme definido anteriormente.

\subsection{2- Análise dos resultados do PIM}

A figura 6.1 demostra as relações entre o diâmetro do poro e o volume acumulado com a distribuição dos poros.

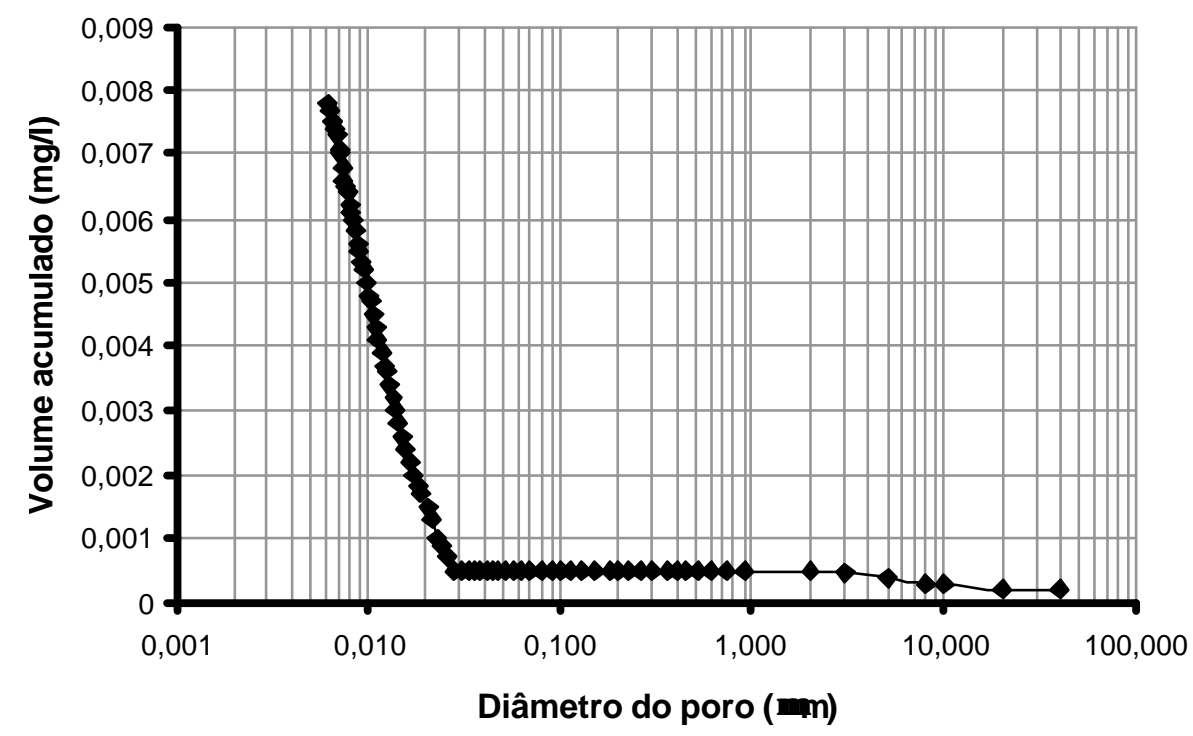

Figura 6.1 - Relação entre o volume acumulado e o diâmetro dos poros obtido por PIM, para amostra de concreto de pós reativos.

O ensaio mostrou que o concreto de pós reativos apresentou porosidade de $1,8 \%$, para poros entre $6 \eta \mathrm{m}$ e $100 \mu \mathrm{m}$, o que pode ser considerado um material com baixíssima porosidade, quando comparado com os concretos de resistência usual e de alta resistência, que possuem porosidade acima de 10\%, dependendo de vários fatores como: relação água/cimento, quantidade de sílica ativa, tipo de cura, etc.

ROUX et al. (1995) compararam resultados de PIM entre concretos com resistências de $30 \mathrm{MPa}, 80 \mathrm{MPa}$, e concretos de pós reativos com resistências de $170 \mathrm{MPa}$ e $230 \mathrm{MPa}$. Suas análises demostraram que o concreto de pós reativos apresentaram porosidade de $1 \%$ para poros entre $6 \eta \mathrm{m}$ e $100 \mu \mathrm{m}$, o que pode ser considerado compatível com os resultados desta pesquisa. 
CHEYREZY et al. (1995) também realizou ensaios de PIM em concreto de pós reativos submetidos a diferentes condições de cura. Para todas as situações analisadas, as amostram apresentaram porosidade sempre abaixo de $9 \%$ para poros entre $3,75 \eta \mathrm{m}$ e $100 \mu \mathrm{m}$.

\section{4- Microscopia Eletrônica de Varredura}

\subsection{1- Introdução}

A análise da estrutura interna do concreto implica em verificar atentamente as condições da estrutura micro, meso e macro. SILVA (2000, p.192) descreve que "[...] No nível micro, as estruturas são descontínuas e não homogênea, tais como moléculas e estruturas de cristais, géis e poros; no nível meso, as estruturas são contínuas e não homogêneas, tais como agregados, partículas de cimento hidratados, partículas de cimento anidra, poros e interfaces; no nível macro, finalmente, o concreto é contínuo e homogêneo."

As observações pela Microscopia Eletrônica de Varredura (MEV) devem considera o caráter heterogêneo das pasta de cimento Portland. MELO (2000) comenta que, ao observar a superfície de uma amostra de pasta de cimento com cerca de $1 \mathrm{~cm}^{2}$, obtendo-se 10 imagens (campos diferentes) com ampliações da ordem de 10.000 vezes, tem-se uma amostragem de 0,001\% da superfície. Se a microestrutura varia de uma região para outra, é difícil assegurar que essa amostra seja adequada para representar a estrutura global da pasta. Torna-se mais difícil ainda dizer se essa amostra é adequada para representar aquela pasta presente no concreto. Por outro lado, é importante a observação da microestrutura para que os conhecimentos evoluam nessa área.

O princípio de funcionamento do MEV consiste basicamente em realizar o varrimento da superfície de uma amostra com um feixe eletrônico finamente focado, em sincronismo com o varrimento de um monitor de visualização, modulando o brilho em cada ponto, pela intensidade de um sinal emitido pela amostra. Obtém-se, deste modo, uma correspondência, ponto a ponto, entre a imagem e a região observada da amostra, que depende da natureza da informação, do tipo de sinal registrado e do detector utilizado.

No processo de varrimento da amostra pelo feixe de elétrons, ocorrem interações que geram, entre outros tipos de sinais, elétrons retroespalhados (BSE), elétrons secundários (SE) e Raios-X. Estes sinais podem ser captados por detectores específicos e gerar imagens da superfície da amostra. 
Os elétrons retroespalhados (BSE) apresentam alta energia e geram imagens com informações sobre uma certa profundidade da superfície da amostra, normalmente polida. A emissão dos elétrons retroespalhados aumenta com o aumento do número atômico do material analisado, permitindo a individualização de fases por meio de contraste de tons de cinza em função do número atômico médio (Z). Para a pasta hidratada, as fases variam de um branco brilhante ao preto, na seguinte seqüência: cimento anidro, hidróxido de cálcio, silicato de cálcio hidratado e outros hidratado, e poros (neste caso, cheios de resina utilizada na impregnação).

Os elétrons secundários (SE) apresentam baixa energia e geram imagens com visualização da topografia da amostra, e são menos sensíveis ao número atômico comparado aos BSE. Para esse tipo de imagem, utiliza-se, usualmente, amostras fraturadas. O detector da SE capta os elétrons em todas as direções da superfície da amostra, possibilitando, assim, obter imagens com aspectos tridimensionais.

Acoplados ao MEV, detectores e sistemas de análises dos Raios-X emitidos da interação do feixe com a amostra, possibilitam a análise qualitativa, semiquantitativa e quantitativa dos elementos presentes na superfície da amostra.

A análise química elementar em um ponto ou em uma área da amostra em termos qualitativos, semiquantitativos e quantitativos, pode ser realizada pela espectrografia de Raios-X por dispersão de energias (EDS), associada a sistemas de análises de Raios-X.

Os métodos de análise qualitativa e semiquantitativa se encontram, habitualmente, disponíveis nos sistemas de EDS e são usualmente utilizados, pois permitem, de forma rápida, a identificação e a determinação da composição dos elementos presentes na amostra. Nesses sistemas de análise, a identificação e a determinação da composição de um elemento são feitas pela comparação da intensidade das riscas espectrais características da amostra com espectros de referência. $A$ análise dos espectros de Raios-X é feita, atualmente, utilizando-se 0 recurso de sistemas informatizados de bibliotecas de espectros, o que torna o processo bastante simples e rápido. (MELO, 2000).

A análise pontual por EDS atua num volume de alguns micrômetros cúbicos, enquanto que as dimensões das partículas dos produtos das reações de hidratação do cimento variam entre alguns nanômetros e um micrômetro, assim, os resultados de uma análise pontual representam a mistura de vários produtos de hidratação com diferentes tipos de composição. Logo, a determinação da composição de uma fase específica torna-se pouco precisa.

No entanto, pode-se obter uma estimativa da composição dos principais produtos da hidratação de cimento, como o $\mathrm{CH}$ (hidróxido de cálcio), C-S-H (silicato de 
cálcio hidratado), AFt (trissulfoaluminato de cálcio - etringita) e AFm (monossulfoaluminato de cálcio), em uma análise pontual considerando as relações entre as massas atômicas de alguns óxidos presentes nesta análise, como $\mathrm{SiO}_{2}, \mathrm{CaO}$, $\mathrm{Fe}_{2} \mathrm{O}_{3}, \mathrm{Al}_{2} \mathrm{O}_{3}$ e $\mathrm{SO}_{3}$. Para a referenciação dos respectivos óxidos, ao longo do trabalho foram utilizadas as seguintes abreviações: $\mathrm{Si}, \mathrm{Ca}, \mathrm{Fe}, \mathrm{Al}$ e S.

Um dado relevante da técnica de microanálise por EDS, é o cálculo das relações $\mathrm{Ca} / \mathrm{Si}, \mathrm{Al} / \mathrm{Ca}, \mathrm{Ca} /(\mathrm{Si}+\mathrm{Al}),(\mathrm{Al}+\mathrm{Fe}) / \mathrm{Ca}, \mathrm{S} / \mathrm{Ca}$, que são muito exploradas na literatura para identificação das fases: anidra, $\mathrm{CH}, \mathrm{C}-\mathrm{S}-\mathrm{H}$, matriz, escória, Aft, Afm, etc.

Pesquisas realizadas por TAYLOR \& NEWBURY (1984), SARKAR et al. (1992) e WASSERMAN \& BENTUR (1996) estabeleceram valores numéricos para associar a presença de alguns produtos do cimento hidratado, em função das relações entre os óxidos mencionados anteriormente. Normalmente, a avaliação da presença dos produtos hidratados do cimento é feita em função da análise conjunta de vários quocientes das massas atômicas dos óxidos, como apresentado abaixo:

$$
\begin{array}{lrll}
C-S-H: & 0,8 \leq \frac{\mathrm{Ca}}{\mathrm{Si}} \leq 2,5 & \frac{(\mathrm{Al}+\mathrm{Fe})}{\mathrm{Ca}} \leq 0,2 & \\
C H: & \frac{\mathrm{Ca}}{\mathrm{Si}} \geq 10 & \frac{(\mathrm{Al}+\mathrm{Fe})}{\mathrm{Ca}} \leq 0,04 & \frac{\mathrm{S}}{\mathrm{Ca}} \leq 0,04 \\
\text { AFm : } & \frac{\mathrm{Ca}}{\mathrm{Si}} \geq 4,0 & \frac{(\mathrm{Al}+\mathrm{Fe})}{\mathrm{Ca}} \leq 0,4 & \frac{\mathrm{S}}{\mathrm{Ca}} \leq 0,15
\end{array}
$$

\subsection{2- Estudo da microestrutura do concreto de pós reativos}

A técnica do MEV foi empregada para a análise de 4 amostras de concreto de pós reativos, com propriedades conforme descritas na tabela 6.1 .

Tabela 6.1- Amostras para o MEV

\begin{tabular}{c|c|c|c|c}
\hline Amostra & Tipo & Fibras & $\begin{array}{c}\text { Resistência } \\
\mathbf{f}_{\mathbf{c}}(\mathbf{M P a})\end{array}$ & $\begin{array}{c}\text { Idade } \\
\text { (dias) }\end{array}$ \\
\hline 1 & Polida & Não & 200 & 148 \\
\hline 2 & Polida & Sim & 200 & 148 \\
\hline 3 & Fraturada & Não & 200 & 148 \\
\hline 4 & Fraturada & Sim & 200 & 148 \\
\hline
\end{tabular}

Os ensaios foram realizados no Laboratório de Microscopia Eletrônica da Central de Análise Química Instrumental do Instituto de Química de São Carlos, onde utilizou-se o seguinte equipamento:

- Microscópio Eletrônico de Varredura (MEV)

- $\quad$ marca: LEICA;

- modelo: LEO 440;

- $\quad$ EDS - marca Oxford/Lynk - modelo eXL II; 
As amostras foram retiradas da parte mais central do corpo-de-prova de concreto de pós reativos hidratado a 148 dias, e que tiveram resistência àcompressão de $213 \mathrm{MPa}$.

As características das amostras e os procedimentos para sua preparação são relacionados abaixo, conforme recomendações de MELO (2000):

- Tamanho: $15 \mathrm{~mm}$ x $15 \mathrm{~mm} \times 5 \mathrm{~mm}$, adequada ao tamanho do porta amostra;

- Cortou-se as amostras utilizando serra com disco diamantado em baixa rotação, lubrificada com água. Desse modo, evitou-se produzir defeitos que não representassem a realidade da amostra;

- Imersão das amostras em álcool isopropílico, durante 24 horas, para induzir a remoção da água livre dos capilares, com objetivo de parar o processo de hidratação.

- As amostras foram submetidas ao processo de secagem à vácuo de $60 \mathrm{~cm} . \mathrm{Hg}$ por 5 minutos, seguida de agitação magnética por 30 minutos, depois, levou-se à vácuo novamente por 5 minutos (operação repetida 4 vezes);

- Em seguida, as amostras foram colocadas em estufa a $60^{\circ} \mathrm{C}$ por 24 horas; e na sequência, colocadas em dissecador onde aplicou-se vácuo, deixando nessa condição durante cerca de 15 horas, àtemperatura de 23 $\pm 2^{\circ} \mathrm{C}$. Este procedimento adotado para secagem das amostras é o mais recomendado por não produzir defeitos na microestrutura;

- Para o preenchimento dos poros, as amostras foram submetidas ao processo de impregnação à vácuo, com embutimento a frio com resina, para preencher a estrutura dos poros e preservá-los durante o polimento. Foi utilizado resina Epofix de dois componentes, cujas propriedades eram: baixo índice de refração, baixa pressão de vapor, boa adesão, baixa viscosidade e falta de retração;

- Após 24 horas, as amostras foram submetidas ao processo de polimento, segundo a seqüência: - desbaste inicial da superfície, com a lixa $N$ ․․ 60 , para remover a resina e expor a superfície da amostra; - lixamento numa seqüência típica, com lixas de carbeto de silício 360, 400, 500, 600, 800, 1000, 1200, 1500, e 2000, em politrizes de disco rotativo por via úmida (óleo mineral). As amostras eram limpas com ultra-som resfriado em álcool isopropílico, antes de passar para o próximo componente mais fino; - O polimento final foi feito utilizando pasta diamantada (suspensão de diamante em óleo mineral) com três diferentes tamanhos de grãos: 6, 1 e 
$0,25 \mu \mathrm{m}$. Em seguida, novamente submetidas ao processo de limpeza em Ultra-som, com resfriamento em álcool isopropílico.

- $\quad$ Após o polimento, as amostras receberam uma fina camada condutora de ouro, espessura da ordem de $200 \AA$, e foram mantidas em dessecador à vácuo e temperatura ambiente, até o instante da análise;

- Às amostras fraturadas dispensaram os trabalhos de impregnação e polimento.

O estudo realizado resumiu-se em identificar algumas fases que fazem parte da microestrutura do concreto de pós reativos. Para isso, analisaram-se 4 amostras, tabela 6.1, por meio do MEV e EDS, onde se registrou micrografias de várias regiões da amostra, em busca de produtos hidratados. Os resultados são relacionados a seguir.

\section{a) Amostra polida, sem fibras}

As amostras polidas foram analisadas com detector de elétrons retroespalhados, permitindo a individualização de fases por meio de contraste de tons de cinza em função do número atômico médio (Z). Para a pasta hidratada, as fases variaram de um branco brilhante ao preto, na seguinte seqüência: cimento anidro, hidróxido de cálcio, silicato de cálcio hidratado e outros hidratado, e poros (neste caso cheios de resina utilizada na impregnação).

A figura 6.2 apresenta a micrografia de uma região da amostra com ampliação de 500 vezes. Pode-se observar que existem poucos pontos na tonalidade preto, onde praticamente todas as fases apresentam tons de branco a cinza escuro, o que demostra a baixíssima quantidade de poros na estrutura interna do CPR.

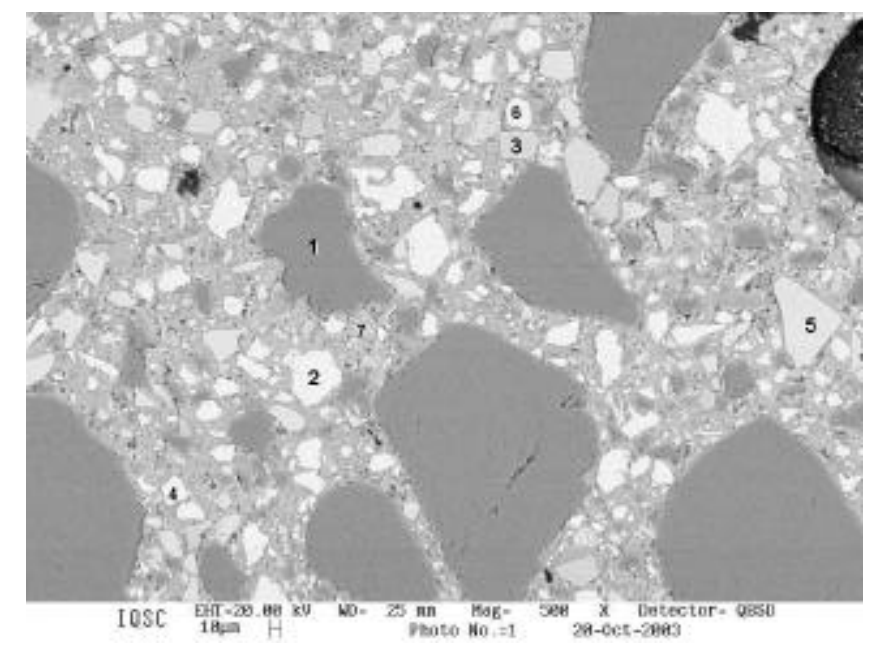

Figura 6.2- Imagem da microestrutura do concreto de pós reativos, ampliada 500 vezes. 
Para identificar as fases existentes, realizou-se EDS em alguns pontos com tonalidades de cinza diferentes, e as relações $[\mathrm{Ca} / \mathrm{Si}, \mathrm{Al} / \mathrm{Ca}, \mathrm{Ca} /(\mathrm{Si}+\mathrm{Al}),(\mathrm{Al}+\mathrm{Fe}) / \mathrm{Ca}$, S/Ca] são apresentadas na tabela 6.2 .

Tabela 6.2- Mapeamento dos tons de cinza da estrutura interna do CPR

\begin{tabular}{c|c|c|c|c|c|c}
\hline \multirow{2}{*}{ Ponto } & \multirow{2}{*}{ Fase } & \multicolumn{5}{|c}{ Relação em \% } \\
\cline { 3 - 7 } & & $\mathbf{C a} / \mathbf{S i}$ & $\mathbf{A l} / \mathbf{C a}$ & $\mathbf{C a} / \mathbf{S i}+\mathbf{A l})$ & $(\mathbf{A l + F e}) / \mathbf{C a}$ & $\mathbf{S} / \mathbf{C a}$ \\
\hline $\mathbf{1}$ & Areia & --- & --- & --- & --- & --- \\
\hline $\mathbf{2}$ & Anidro & 3,170 & 0,021 & 2,970 & --- & --- \\
\hline $\mathbf{3}$ & Escória & 0,682 & 0,440 & 0,530 & --- & --- \\
\hline $\mathbf{4}$ & Afm & 6,000 & 0,349 & 1,940 & 0,535 & --- \\
\hline $\mathbf{5}$ & Escória & 1,287 & 0,270 & 0,955 & 0,282 & 0,033 \\
\hline $\mathbf{6}$ & Anidro & 3,083 & 0,020 & 2,908 & 0,025 & 0,001 \\
\hline $\mathbf{7}$ & Matriz & 1,311 & 0,026 & 1,268 & 0,034 & 0,062 \\
\hline
\end{tabular}

Para se ter idéia da quantidade de poros no concreto de pós reativos, a figura 6.3 mostra uma visão geral da amostra, que foi ampliada apenas 70 vezes. Nesta imagem pode-se observar algumas regiões escuras, que representam os poros preenchidos com resina. Essas regiões escuras apresentam tamanhos iguais ou maiores que os grãos de areia, com formas circulares, podendo-se afirmar que são macro poros provenientes do ar aprisionado no concreto, onde não apresentam conexões entre si. A quantidade de macro poros é considerável, quando comparada com o tamanho da amostra, evidenciando a incorporação de ar no processo de mistura e moldagem.

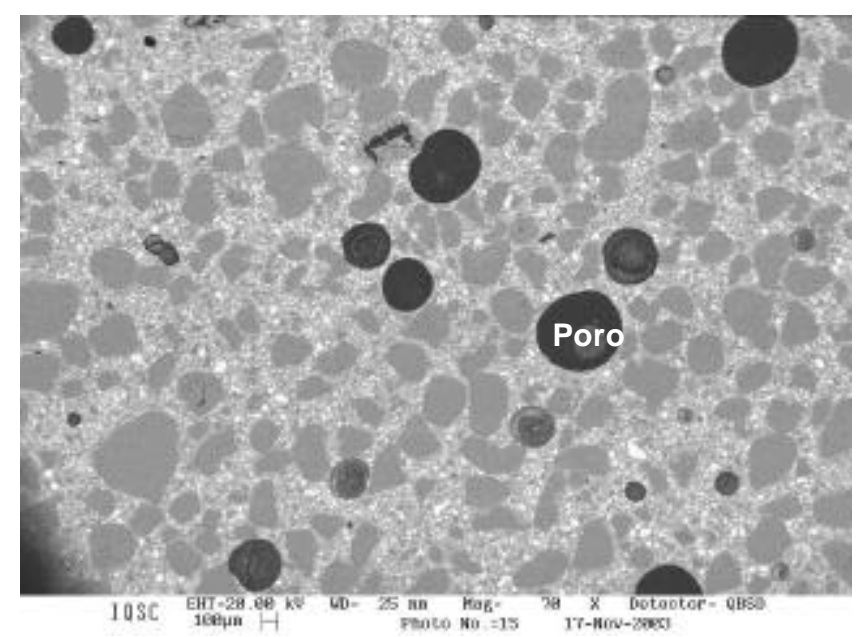

Figura 6.3- Imagem geral da amostra ampliada 70 vezes.

A figura 6.4 mostra três regiões da estrutura interna do CPR, ampliada 4000 vezes. Nestas áreas foram realizados EDS onde as relações são mostradas na tabela 6.3. 


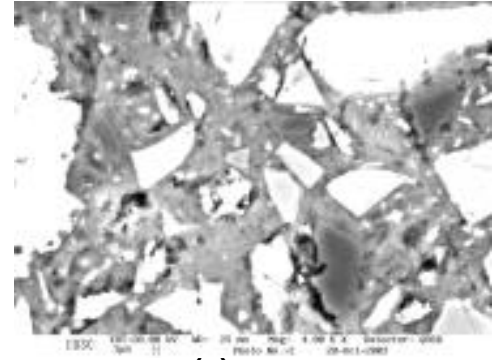

(a)

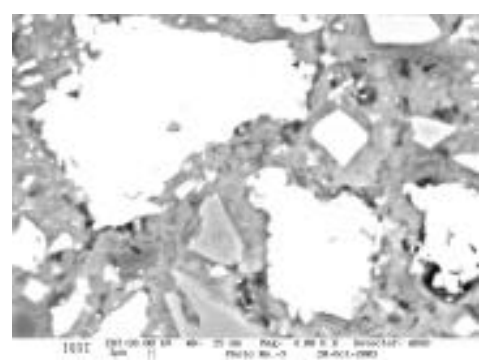

(b)

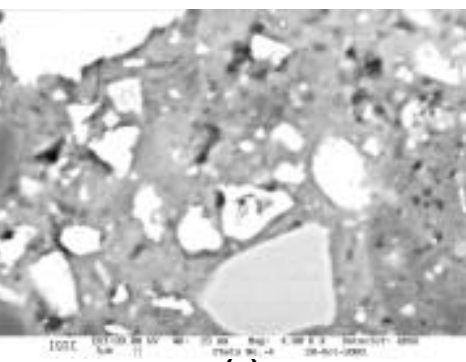

(c)

Figura 6.4- Micrografia de regiões da microestrutura do CPR, ampliação de 4000 vezes.

Tabela 6.3- EDS de áreas da estrutura interna do CPR, com magnitude de 4000 vezes

\begin{tabular}{c|c|c|c|c|c|c}
\hline \multirow{2}{*}{ Região } & \multirow{2}{*}{ Fase } & \multicolumn{5}{|c}{ Relação em \% } \\
\cline { 3 - 7 } & & $\mathbf{C a} / \mathbf{S i}$ & $\mathbf{A l} / \mathbf{C a}$ & $\mathbf{C a} / \mathbf{( S i}+\mathbf{A l})$ & $(\mathbf{A l + F e} / \mathbf{C a}$ & $\mathbf{S} / \mathbf{C a}$ \\
\hline a & C-S-H & 1,004 & 0,102 & 0,911 & 0,139 & 0,036 \\
\hline b & C-S-H & 0,920 & 0,065 & 0,868 & 0,092 & 0,035 \\
\hline c & C-S-H & 1,011 & 0,107 & 0,912 & 0,141 & 0,052 \\
\hline
\end{tabular}

A figura 6.5 mostra a interface entre a pasta e o grão de areia, com magnitude de 929 vezes. Nota-se que a região de interface é bem definida, com ausência de poros, podendo se definida como homogênea e coesiva.

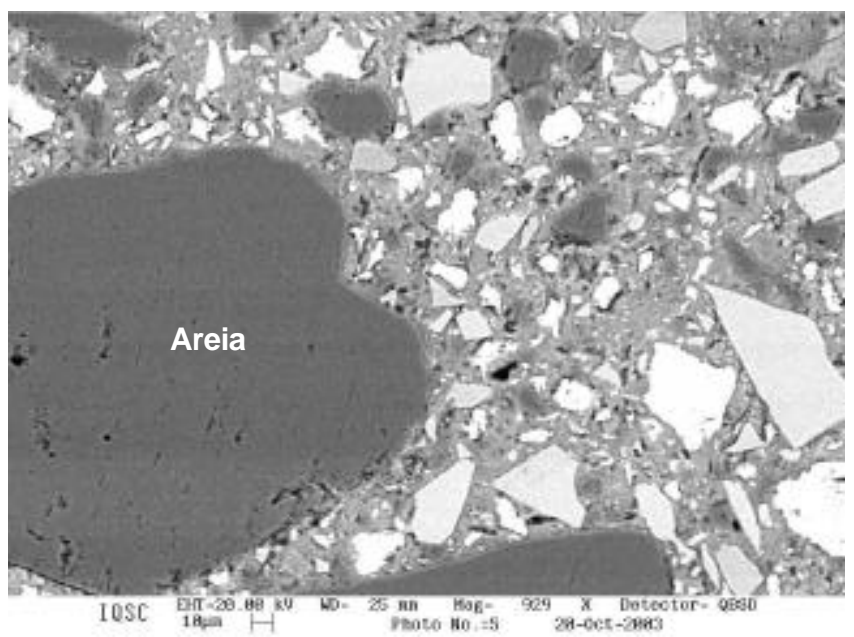

Figura 6.5- Interface entre o grão de areia e a pasta, ampliação de 928 vezes.

A figura 6.6 apresenta quatro regiões diferentes da amostra, onde se percebe as mesmas características em todas as regiões.

\section{b) Amostra polida, contendo fibras (2)}

A amostra polida que continham fibras, foi analisada com detector de elétrons retroespalhados, da mesma maneira que a amostra 1.

A figura 6.7 apresenta uma região da amostra com ampliação de 500 vezes, onde se pôde observar a fibra metálica representada por uma grande região na tonalidade branca, e, ao seu redor, os agregados e fases do cimento hidratado em 
tonalidades de cinza claro ao cinza escuro, além de pequenos pontos pretos, que são os micro poros.

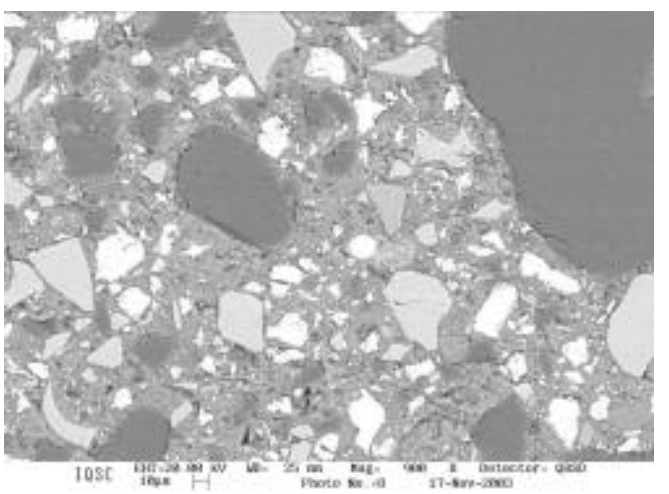

(a)

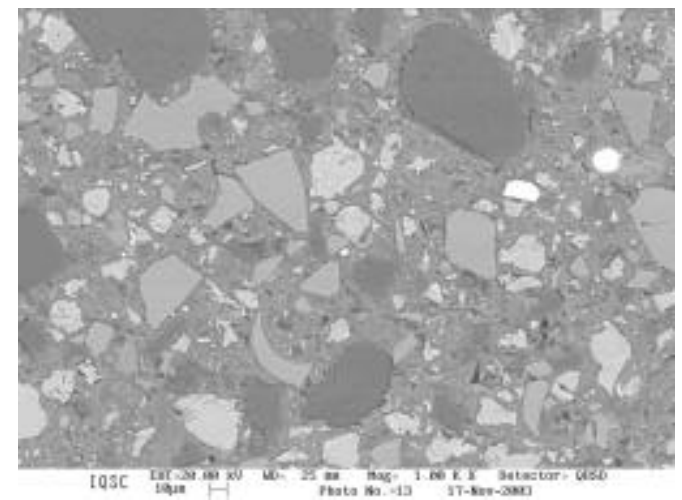

(c)

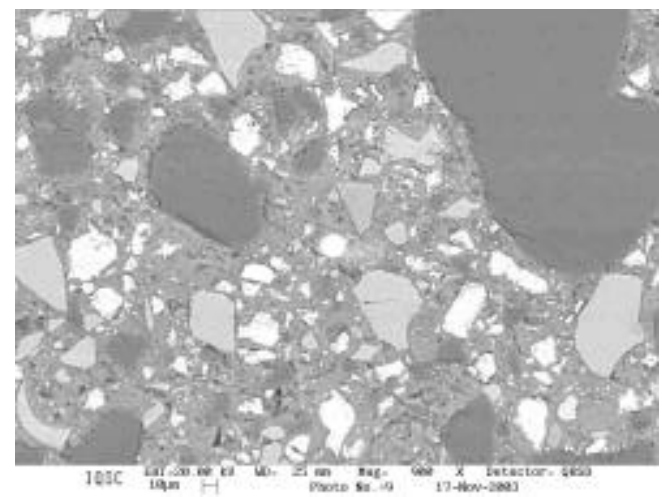

(b)

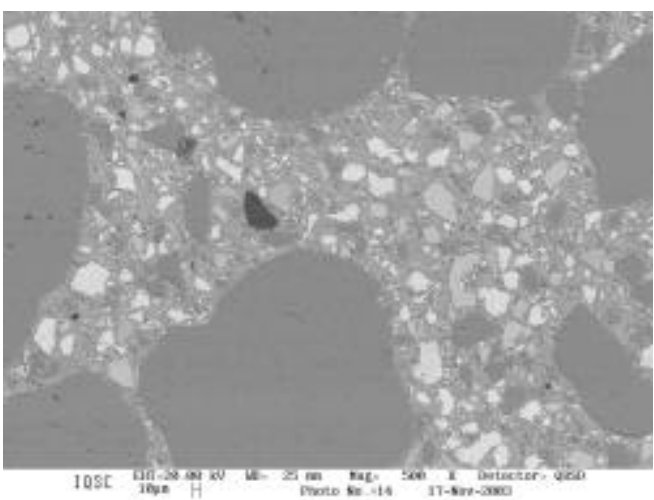

(d)

Figura 6.6- Imagens de 4 regiões diferentes da amostra: a) magnificação de 900x; b) magnificação de 900x; c) magnificação de 1000x; d) magnificação de 500x.

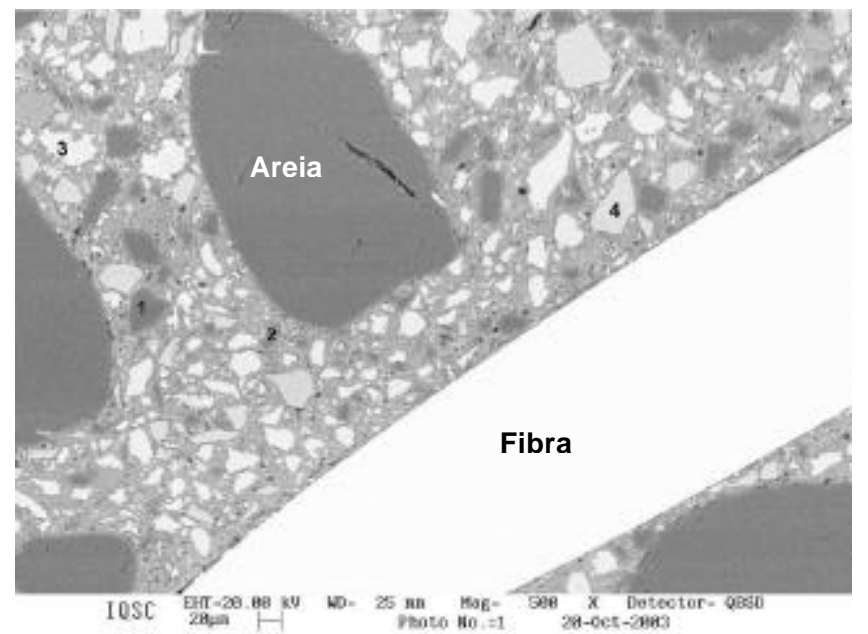

Figura 6.7- Imagem da microestrutura do CPR com fibras metálicas, ampliada 500 vezes.

As fases foram identificadas por EDS em alguns pontos com tonalidades de cinza diferentes, e as relações $[\mathrm{Ca} / \mathrm{Si}, \mathrm{Al} / \mathrm{Ca}, \mathrm{Ca} /(\mathrm{Si}+\mathrm{Al}),(\mathrm{Al}+\mathrm{Fe}) / \mathrm{Ca}, \mathrm{S} / \mathrm{Ca}]$ são apresentadas na tabela 6.4 . 
Tabela 6.4- Mapeamento dos tons de cinza da estrutura interna do CPR com fibras

\begin{tabular}{c|c|c|c|c|c|c}
\hline \multirow{2}{*}{ Ponto } & \multirow{2}{*}{ Fase } & \multicolumn{5}{|c}{ Relação em \% } \\
\cline { 3 - 7 } & & $\mathbf{C a} / \mathbf{S i}$ & $\mathbf{A l} / \mathbf{C a}$ & $\mathbf{C a} /(\mathbf{S i}+\mathbf{A l})$ & $(\mathbf{A l + F e}) / \mathbf{C a}$ & $\mathbf{S} / \mathbf{C a}$ \\
\hline $\mathbf{1}$ & Areia & --- & --- & --- & --- & --- \\
\hline $\mathbf{2}$ & $\mathrm{SiO}_{2}$ & 0,011 & --- & --- & --- & --- \\
\hline $\mathbf{3}$ & Anidro & 3,344 & 0,013 & 3,202 & --- & --- \\
\hline $\mathbf{4}$ & Escória & 1,390 & 0,246 & 1,036 & --- & --- \\
\hline
\end{tabular}

A figura 6.8 mostra uma visão geral da amostra do CPR com fibras, que foi ampliada apenas 70 vezes. Nesta imagem pode-se observar algumas regiões escuras, que representam os macro poros e fissuras localizadas próximas a algumas fibras. As fissuras podem ser provenientes do mal adensamento do concreto, ou provocadas no processo de polimento.

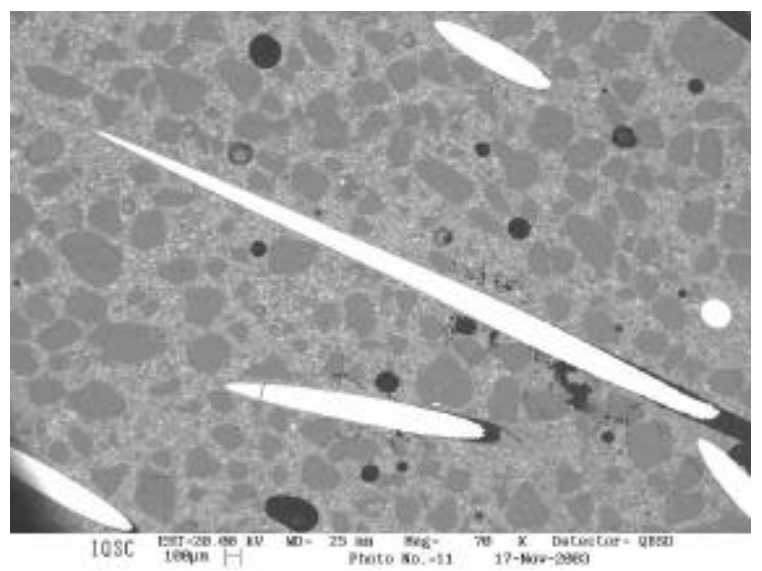

Figura 6.8- Imagem geral da amostra ampliada 70 vezes.

A figura 6.9 apresenta duas regiões da amostra ampliada 4000 vezes. Nestas áreas foram realizados EDS, onde as relações são mostradas na tabela 6.5.

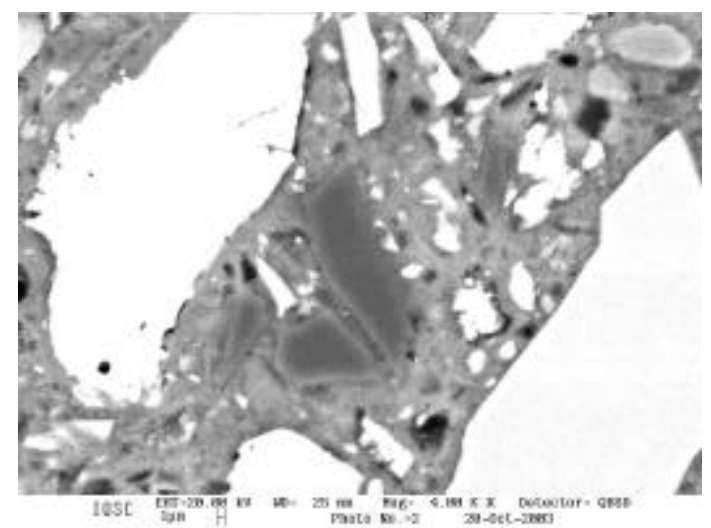

(a)

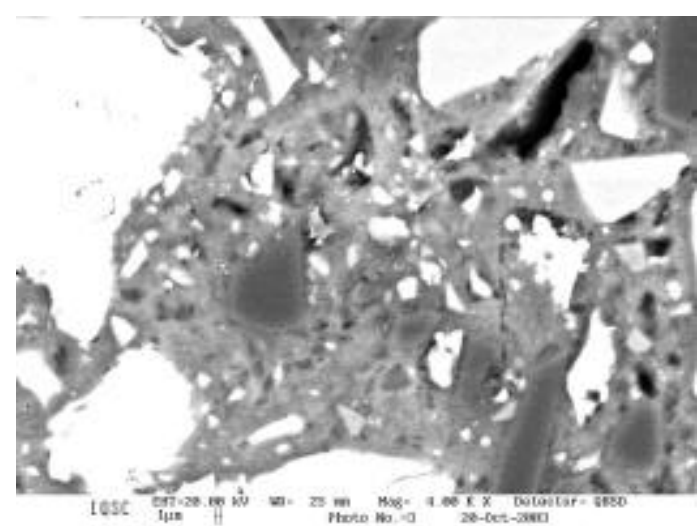

(b)

Figura 6.9- Micrografia de regiões da microestrutura do CPR, ampliação de 4000 vezes. 
Tabela 6.5- EDS de áreas da estrutura interna do CPR, com magnitude de 4000vezes

\begin{tabular}{c|c|c|c|c|c|c}
\hline \multirow{2}{*}{ Ponto } & \multirow{2}{*}{ Fase } & \multicolumn{5}{|c}{ Relação em \% } \\
\cline { 3 - 7 } & & $\mathbf{C a} / \mathbf{S i}$ & $\mathbf{A l} / \mathbf{C a}$ & $\mathbf{C a} /(\mathbf{S i}+\mathbf{A l})$ & $(\mathbf{A l}+\mathbf{F e}) / \mathbf{C a}$ & $\mathbf{S} / \mathbf{C a}$ \\
\hline $\mathbf{a}$ & C-S-H & 1,093 & 0,101 & 0,984 & -- & -- \\
\hline b & Matriz & 1,407 & 0,050 & 1,314 & --- & -- \\
\hline
\end{tabular}

A figura 6.10 apresenta três regiões de interface entre fibra na direção longitudinal, e a matriz que a envolve. A imagem (a) apresenta alguns traços mais escuros, que podem ser fissuras decorrentes do polimento da amostra, ainda observase pontos pretos que representam micro poros espalhados pela matriz. As imagens (b) e (c) apresentam diferentes regiões de interfaces, no entanto, com as mesmas propriedades.

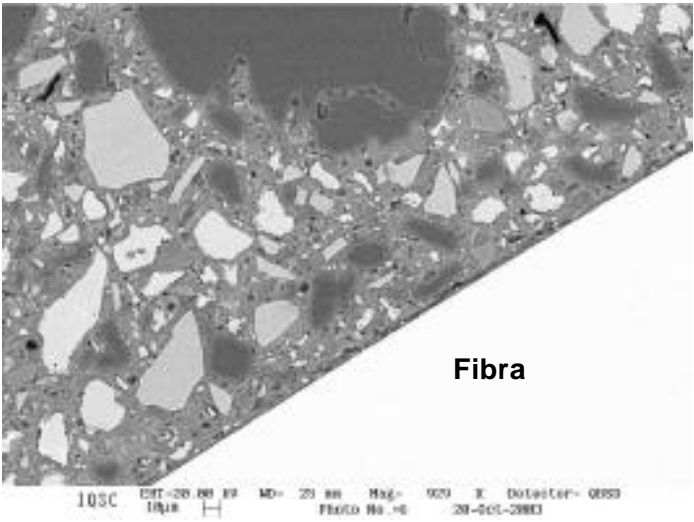

(a)

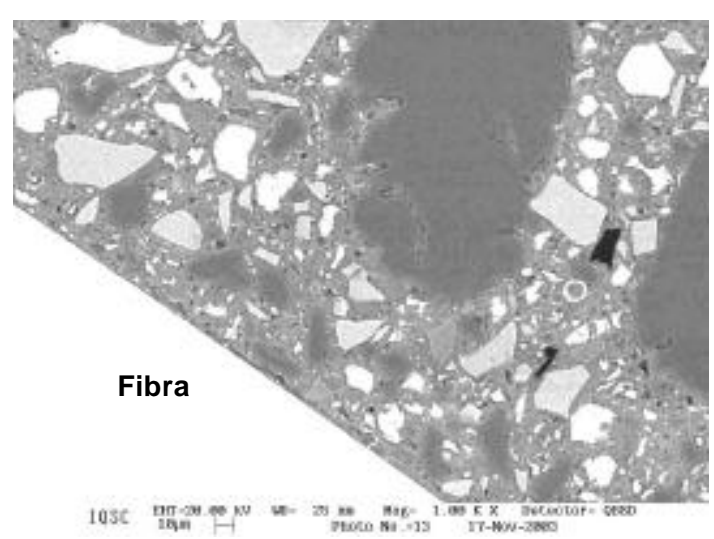

(b)

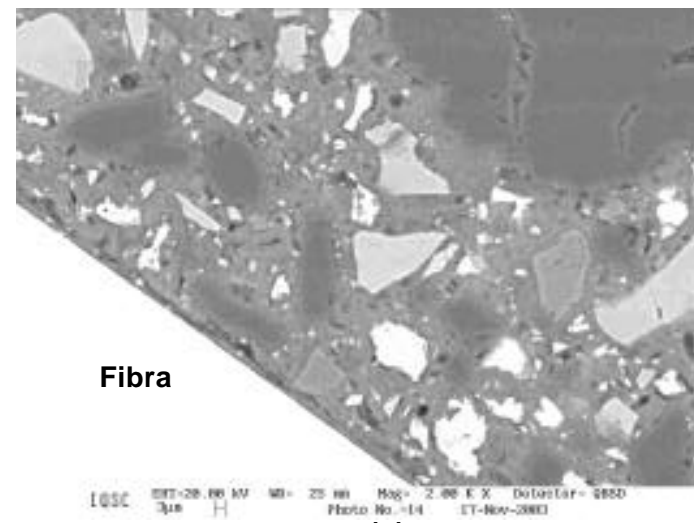

(c)

Uma visão da interface matriz - fibra na posição transversal, é apresentada na figura 6.11. A imagem (a) mostra a fibra vista de topo com ampliação de 1000 vezes, e a imagem (b) apresenta a mesma fibra com ampliação de 2000 vezes. As imagens apresentam interface bem definida, com ausência de traços escuros, o que leva a crer que os traços escuros vistos na figura 6.10, com as fibras na posição longitudinal, podem ser decorrentes do preparo da amostra nas fases de corte e/ou polimento. 


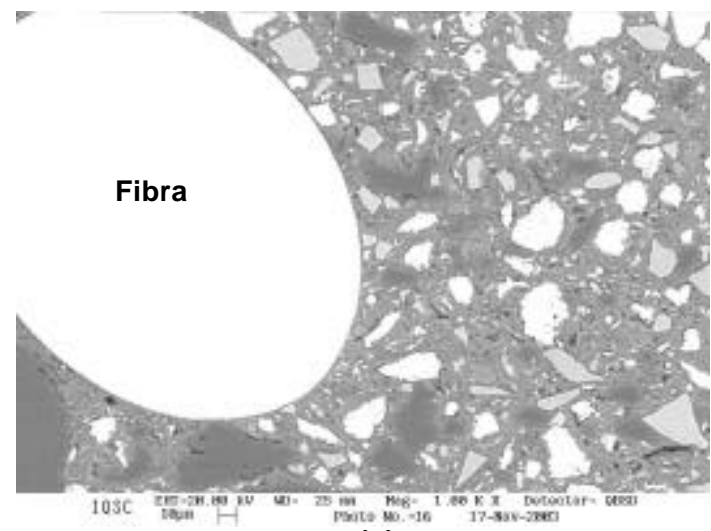

(a)

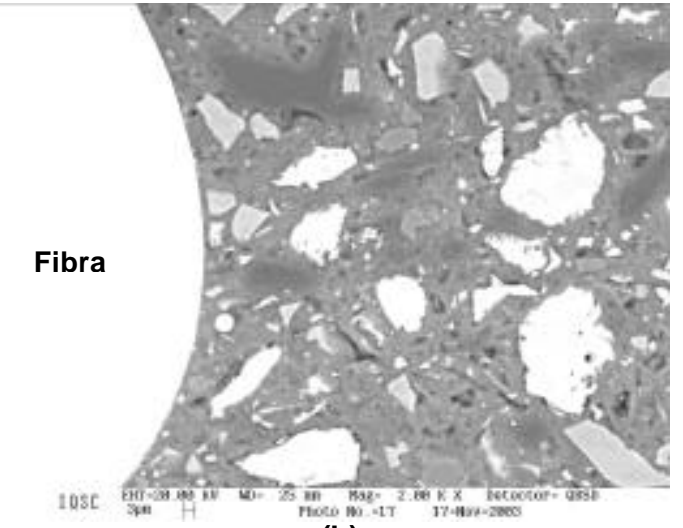

(b)

Figura 6.11- Imagens da interface entre a fibra na direção longitudinal e a matriz: a) magnificação de 1000x; b) magnificação de 2000x.

\section{c) Amostra fraturada, sem fibras (3)}

As amostras fraturadas foram analisadas com detector de elétrons secundários (SE), permitindo visualização da topografia da amostra. Para a pasta hidratada, as fases foram identificadas de acordo com sua textura e morfologia, além da utilização do EDS em algumas regiões.

Algumas micrografias das amostras fraturadas foram feitas no Centro de Caracterização e Desenvolvimento de Materiais (CCDM) da Universidade Federal de São Carlos - UFSCar, onde o equipamento tinha as mesmas propriedades que o do citado anteriormente, no entanto, o operador do equipamento mostrou-se mais experiente em análise de amostras de concreto, obtendo assim, imagens com melhores resoluções.

A figura 6.12 apresenta a micrografia de uma região da amostra com ampliação de 200 vezes. Pode-se observar a morfologia e textura da superfície fraturada do CPR, onde se destacam os grãos de areia, em tonalidade escura, e poros circulares provenientes de ar incorporado.

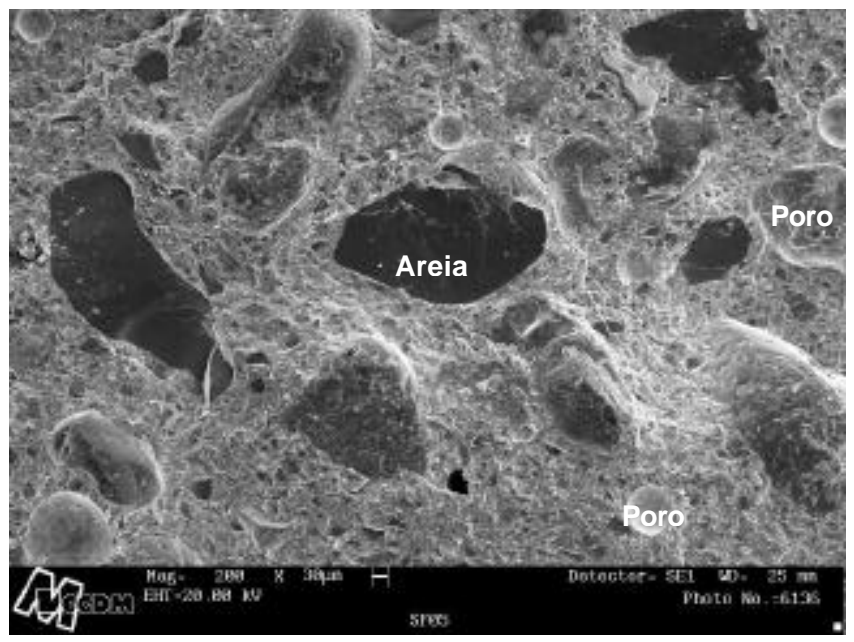

Figura 6.12- Imagem da amostra fraturada ampliada 200 vezes. 
A figura 6.13 mostra a textura densa da superfície fraturada, onde a imagem (a) foi ampliada 1000 vezes, e a imagem (b) é a mesma região ampliada 5000 vezes.

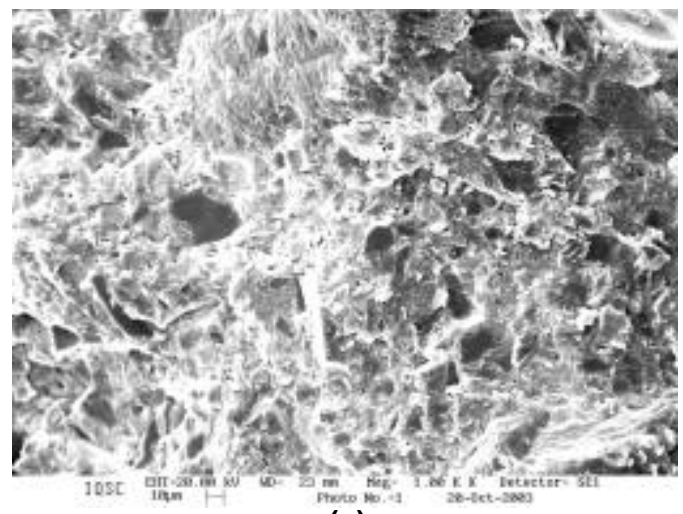

(a)

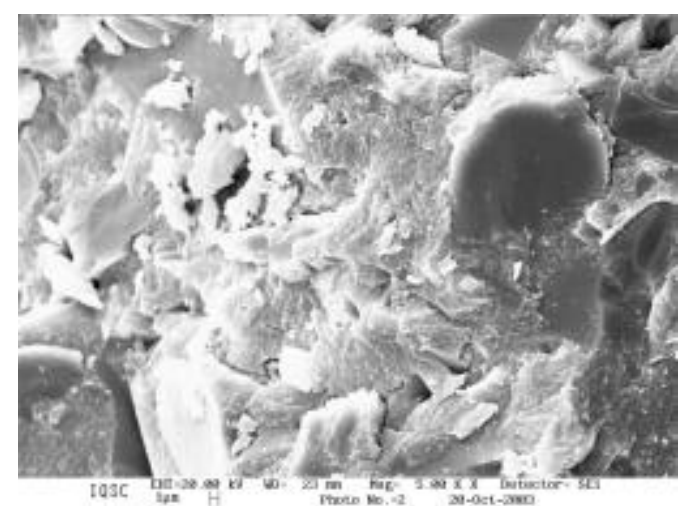

(b)

Figura 6.13- Textura e morfologia da superfície fraturada:

a) magnificação $1000 x$; b) magnificação de 5000x.

A figura 6.14 mostra o produto hidratado C-S-H na parede de uma fissura, causada, provavelmente, pelo álcool isopropílico durante a preparação da amostra. A imagem (a) dá uma visão geral da fissura ampliada 500 vezes, enquanto a imagem (b) faz uma ampliação de 45.000 vezes, mostrando detalhes da superposição de placas de C-S-H.

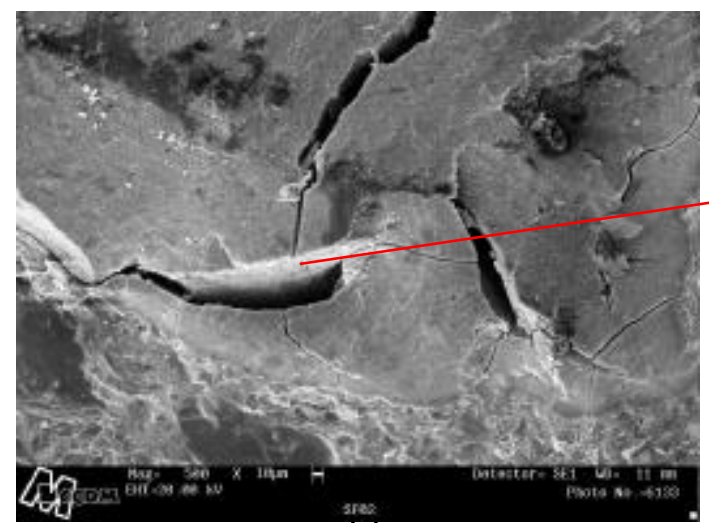

(a)

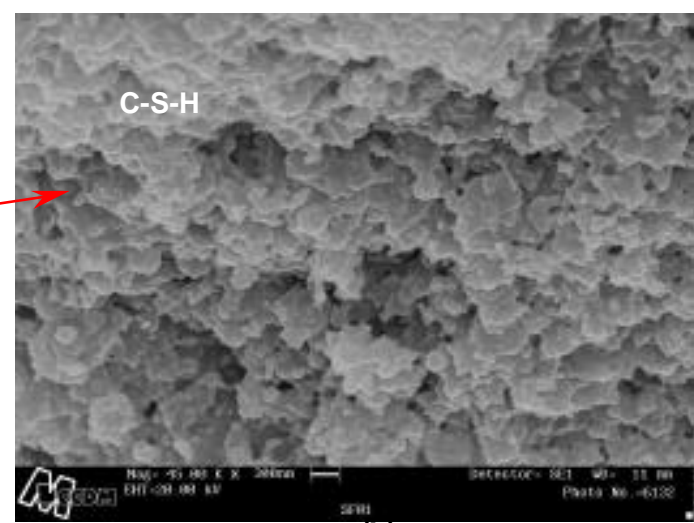

(b)

Figura 6.14- Textura e morfologia da superfície de uma fissura:

a) magnificação 500x; b) magnificação de 45000x.

A figura 6.15 mostra o detalhe da textura e morfologia do produto hidratado na superfície fraturada, C-S-H. A imagem (a) foi ampliada 15000 vezes, enquanto a imagem (b) é uma ampliação de 25.000 vezes da mesma região. 


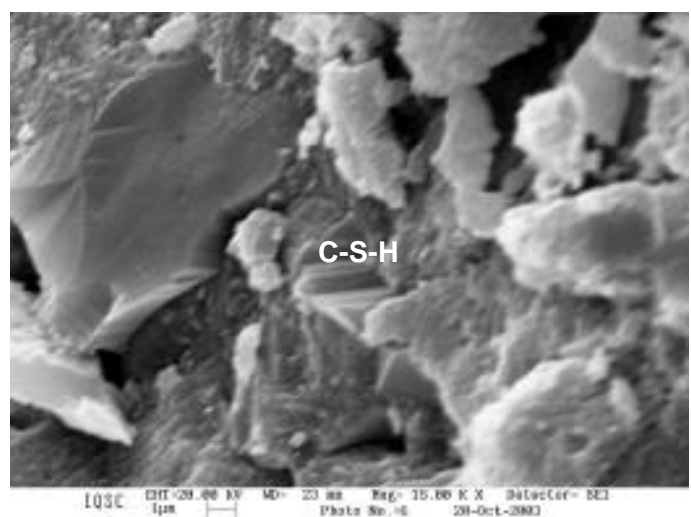

(a)

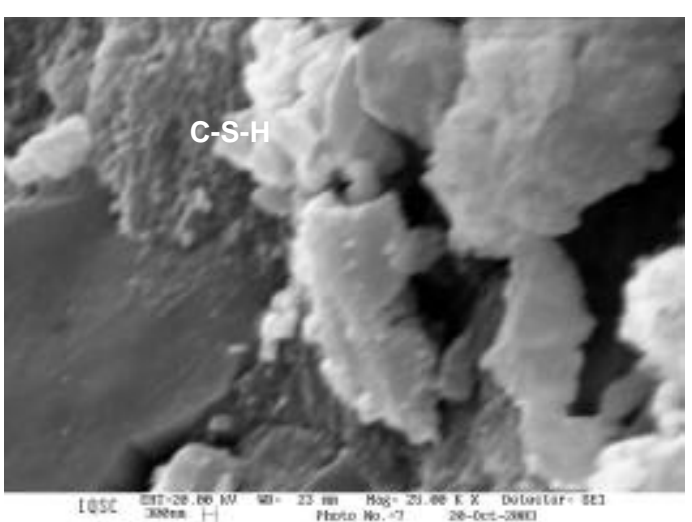

(b)

Figura 6.15- Detalhe da textura e morfologia da superfície fraturada: a) magnificação $15000 x$; b) magnificação de 25000x.

A figura 6.16 mostra mais um detalhe da textura e morfologia do produto hidratado na superfície fraturada, localizado em outra parte da amostra. A imagem (a) foi ampliada 10000 vezes, enquanto a imagem (b) é uma ampliação de 30.000 vezes da mesma região.

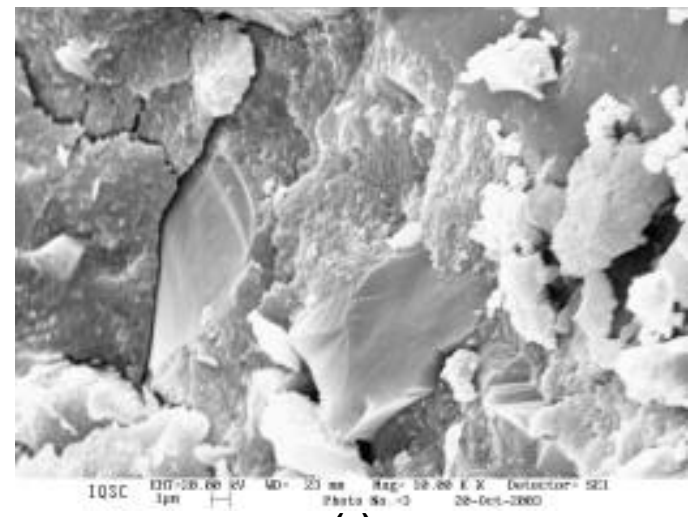

(a)

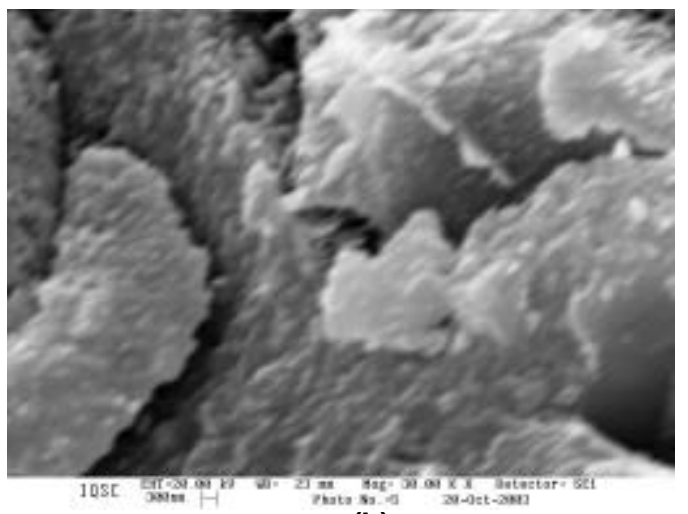

(b)

Figura 6.16- Detalhe da textura e morfologia da superfície fraturada:

a) magnificação $10000 x$; b) magnificação de 30000x.

Mais um tipo de morfologia de produto hidratado na superfície fraturada é mostrado na figura 6.17, onde a imagem (a) apresenta uma região ampliada 2000 vezes, com tipo diferente de textura, e a imagem (b) faz uma ampliação de 10.000 vezes dessa região. A identificação do produto hidratado foi feita por EDS, cuja relações são mostradas na tabela 6.6.

Tabela 6.6- EDS do produto hidratado no ponto 2.

\begin{tabular}{c|c|c|c|c|c|c}
\hline \multirow{2}{*}{ Ponto } & \multirow{2}{*}{ Fase } & \multicolumn{5}{|c}{ Relação em \% } \\
\cline { 3 - 7 } & & $\mathbf{C a} / \mathbf{S i}$ & $\mathbf{A l} / \mathbf{C a}$ & $\mathbf{C a} /(\mathbf{S i}+\mathbf{A l})$ & $(\mathbf{A l}+\mathbf{F e}) / \mathbf{C a}$ & $\mathbf{S} / \mathbf{C a}$ \\
\hline $\mathbf{2}$ & $\mathrm{C}-\mathrm{S}-\mathrm{H}$ & 0,496 & 0,180 & 0,455 & 0,204 & -- \\
\hline
\end{tabular}




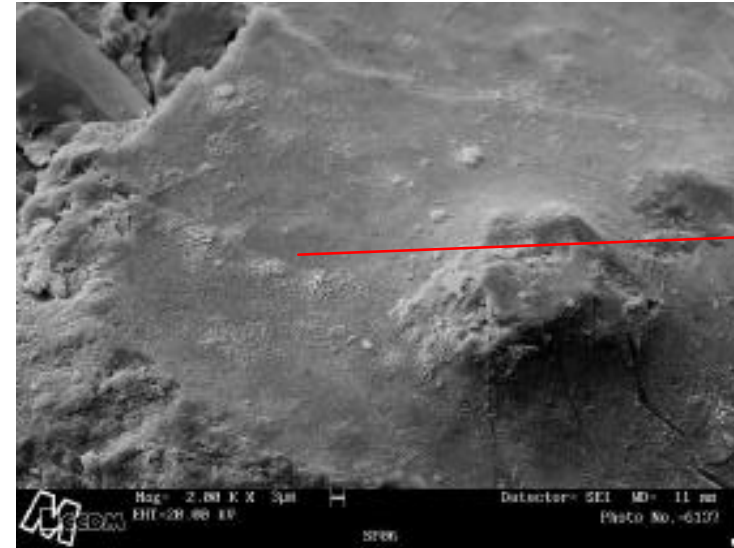

(a)

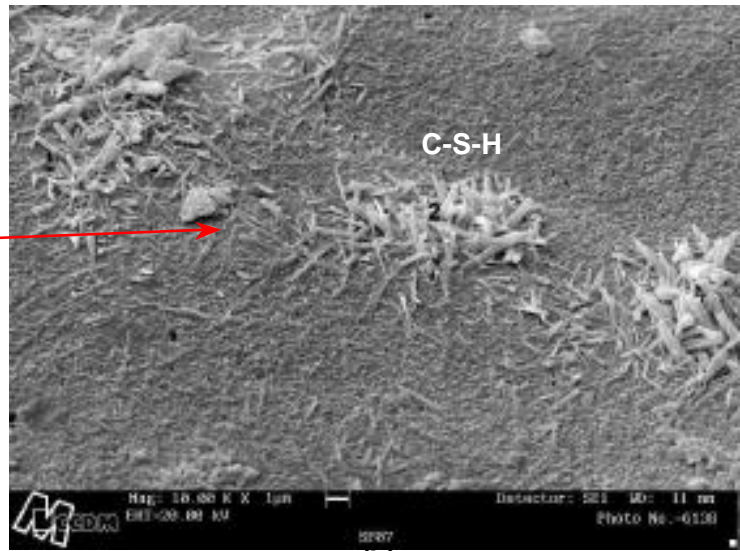

(b)

Figura 6.17- Detalhe da textura e morfologia da superfície fraturada: a) magnificação 2000x; b) magnificação de 10000x.

Outros tipos de formação de produtos hidratados são mostrados nas figuras 6.18 e 6.19. Na imagem da figura 6.19 foi feito EDS que identificou a fase $\mathrm{C}-\mathrm{S}-\mathrm{H}$.

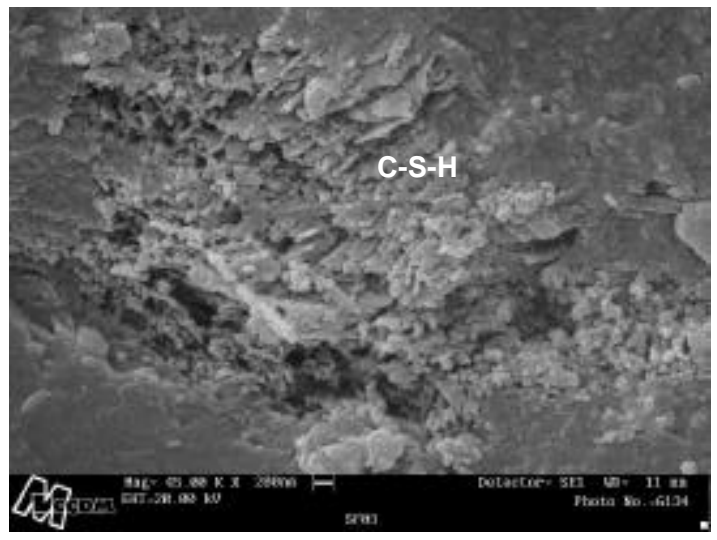

Figura 6.18- Detalhe do C-S-H formado na superfície fraturada, magnificação de 45000x.

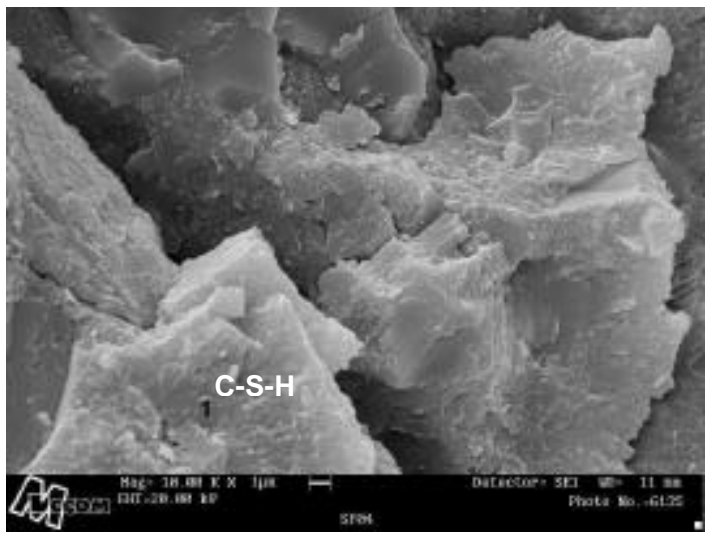

Figura 6.19- Detalhe do C-S-H formado na superfície fraturada, magnificação de $10000 x$.

\section{d) Amostra fraturada, contendo fibras (4)}

A amostra fraturada contento fibras foi analisada com detector de elétrons secundários (SE), da mesma maneira que a amostra 3.

A figura 6.20 apresenta duas imagens ampliadas 100 vezes, onde se mostra a distribuição descontínua das fibras na matriz, assim como, a morfologia e textura da superfície fraturada do CPR. 


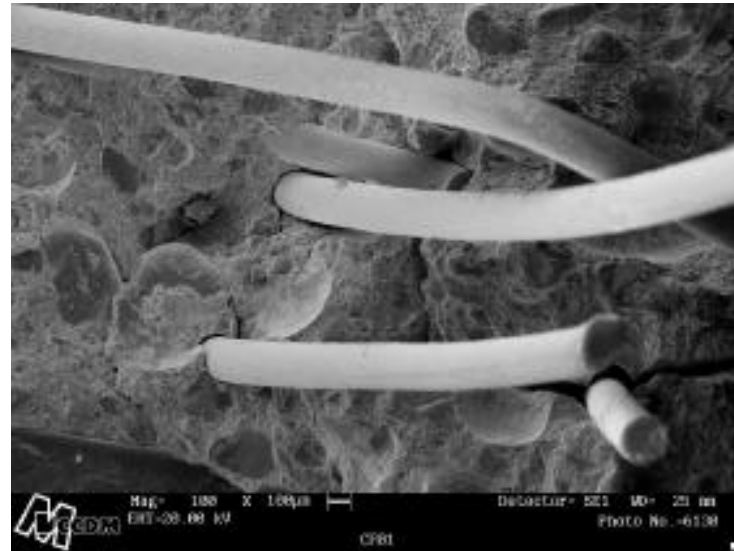

(a)

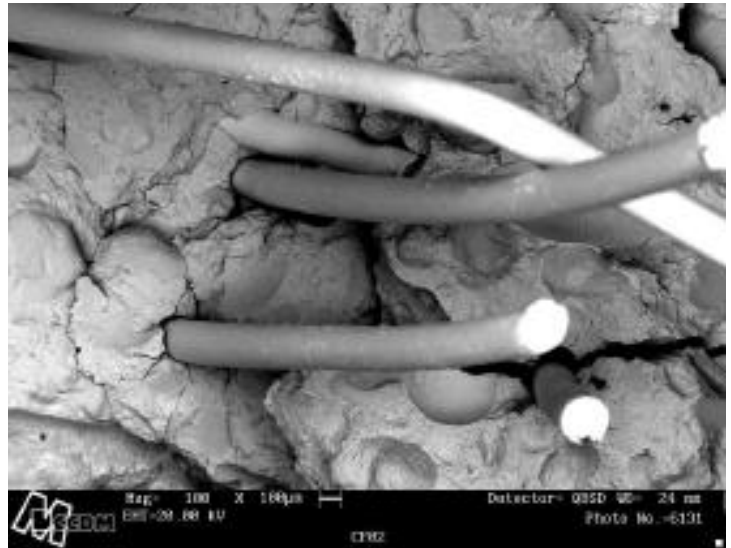

(b)

Figura 6.20- Imagem da amostra fraturada contendo fibras, ampliada 100 vezes.

A figura 6.21 mostra um furo na matriz, ampliado 450 vezes, proveniente do arrancamento de uma fibra quando ocorreu a fratura da amostra. Para conhecer os produtos hidratados que são formados na interface entre a fibras e a matriz, fez-se um EDS de um ponto da parede do furo, cujas relações são apresentadas na tabela 6.7.

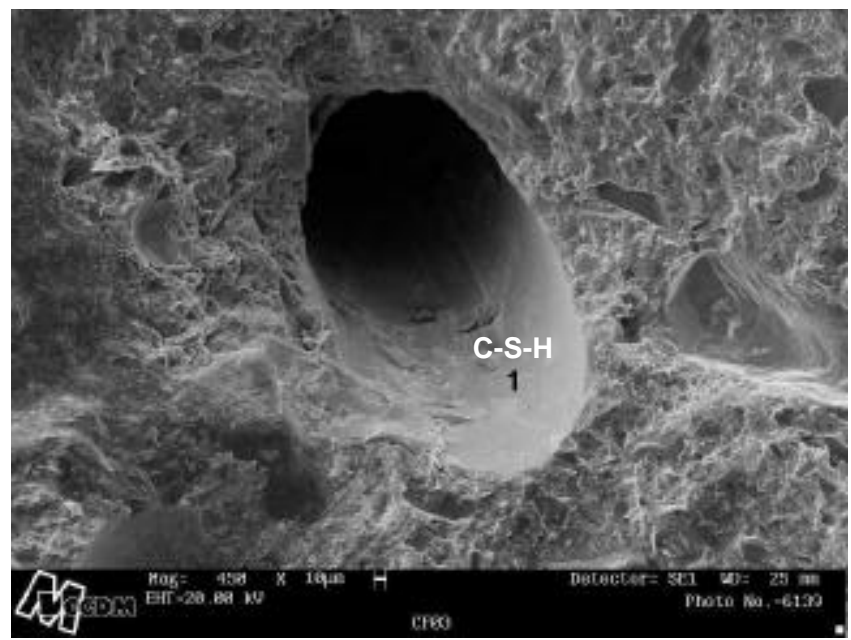

Figura 6.21- Imagem da amostra fraturada contendo fibras, ampliada 100 vezes.

Tabela 6.7- EDS do produto hidratado nos pontos 1 e 2.

\begin{tabular}{c|c|c|c|c|c|c}
\hline \multirow{2}{*}{ Ponto } & \multirow{2}{*}{ Fase } & \multicolumn{5}{|c}{ Relação em \% } \\
\cline { 3 - 7 } & & $\mathbf{C a} / \mathbf{S i}$ & $\mathbf{A l} / \mathbf{C a}$ & $\mathbf{C a} /(\mathbf{S i}+\mathbf{A l})$ & $(\mathbf{A l}+\mathbf{F e}) / \mathbf{C a}$ & $\mathbf{S} / \mathbf{C a}$ \\
\hline $\mathbf{1}$ & C-S-H & 0,574 & 0,102 & 0,542 & 0,150 & --- \\
\hline $\mathbf{2}$ & C-S-H & 0,733 & 0,051 & 0,707 & 0,065 & --- \\
\hline
\end{tabular}

A figura 6.22 também mostra um furo na matriz, proveniente do arrancamento de uma fibra. A imagem (a) apresenta uma visão com ampliação de 250 vezes, enquanto que a imagem (b) faz uma ampliação da parede do furo no ponto 2 de 30000 vezes, onde se realizou um EDS, cujas relações são apresentadas na tabela 6.7. 


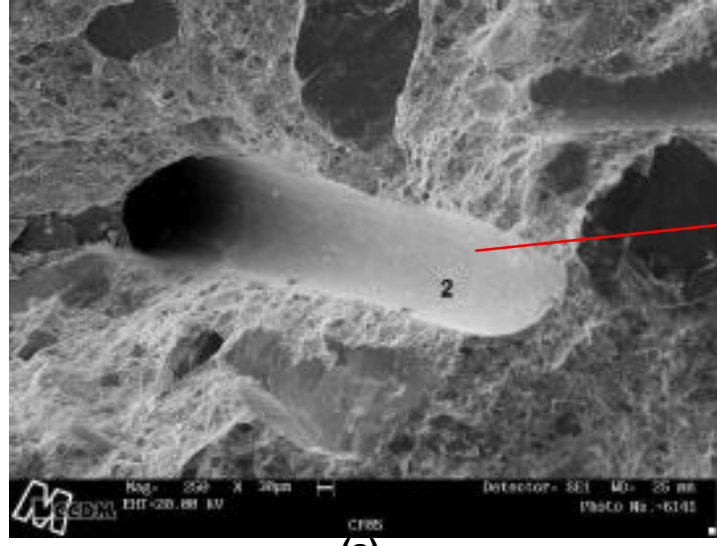

(a)

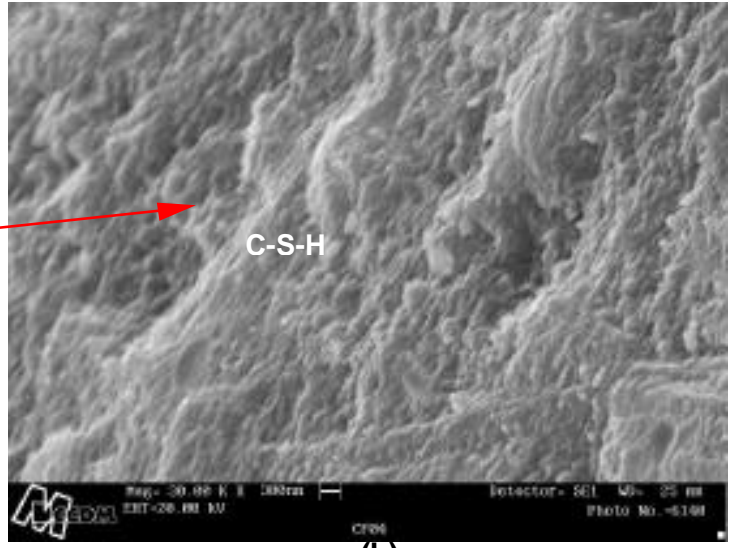

(b)

Figura 6.22- Imagem da amostra fraturada contendo fibras: a) magnificação $250 x$; b) magnificação de $30000 x$.

\section{Considerações Finais}

Segundo o resultado da análise da porosimetria por intrusão de mercúrio (PIM) e as micrografias (MEV) com EDS realizados nas amostras de concreto de pós reativos, pode-se deduzir que:

- O CPR é um material com baixíssima porosidade, o que pode conferir alta resistência e durabilidade;

- Não foi encontrado nos EDS realizados a fase $\mathrm{CH}$ (hidróxido de cálcio), o que pode ser proveniente da alta quantidade de sílica ativa contida na mistura, que reagiu com o $\mathrm{CH}$ e provocou uma maior quantidade de silicato de cálcio hidratado (C-S-H) na matriz;

- A microestrutura mostrou-se bem densa, com aparecimento de macro poros decorrentes do ar aprisionado durante a mistura e moldagem dos modelos;

- A interface entre a pasta e os grãos de areia mostrou-se bem densa, homogênea e coesa, tornando a zona de transição praticamente nula;

- A ligação pasta - fibra também mostrou-se bem definida, com grande concentração de C-S-H;

- A microestrutura do concreto de pós reativos mostrou-se diferente dos concretos usuais e de alto desempenho, ou seja, muito mais densa e com baixíssima porosidade, o que confere a este tipo de material altíssimas resistências e durabilidade. 


\section{Capítulo}

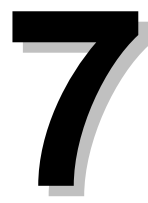

CONCLUSÃO

Neste capítulo são apresentadas as conclusões desta pesquisa, e são feitas sugestões para a continuidade do trabalho. 
Durante os estudos experimentais desta pesquisa, percebeu-se que o grande obstáculo a ser superado, seria desenvolver uma dosagem para o concreto de pós reativos, utilizando os materiais disponíveis na região e procedimentos adequados, a fim de alcançar um concreto com boa trabalhabilidade, além de altíssima resistência à compressão, durabilidade e com ductilidade razoável.

De acordo com a bibliografia consultada, pôde-se chegar as seguintes definições:

$\checkmark$ O concreto de pós reativo é composto de areia de quartzo, cimento, pó de quartzo, sílica ativa, fibras de aço de pequenas dimensões, superplastificante e água, onde os sólidos possuem tamanhos variando entre $2 \mathrm{~mm}$ e $0,5 \mu \mathrm{m}$. Sua fabricação pode ocorrer em condições semelhantes àdos concretos convencionais, porém com baixa relação água/cimento;

$\checkmark$ O estudo de dosagem para obtenção do CPR deve seguir os seguintes princípios: aumento da homogeneidade pela eliminação do agregados graúdos; aumento da densidade pela otimização da distribuição granulométrica dos grãos e/ou aplicação de pressão no preparo; melhor microestrutura utilizando tratamento térmico durante a cura; aumento da ductilidade pela incorporação de fibras de aço; realizar a mistura e a moldagem de tal modo a gastar o menor tempo possível entre as operações;

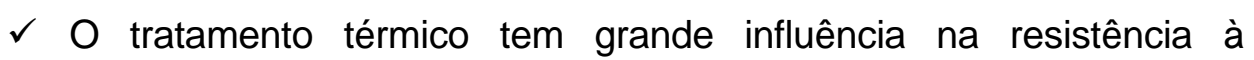
compressão, provocando uma microestrutura mais densa, melhorando a resistência àcompressão e a durabilidade;

$\checkmark$ Apenas a pesquisa publicada por BEHLOUL (1995), definiu com clareza uma relação constitutiva para o CPR.

Os estudos experimentais realizados, proporcionaram o desenvolvimento do concreto de pós reativos no Brasil, utilizando os materiais disponíveis na região.

Com as análises feitas sobre o método de dosagem e procedimentos de moldagem, adensamento e cura, concluiu-se que:

$\checkmark$ método do empacotamento proposto por "Andreassen e Andersen", mostrou-se eficiente na definição das proporções de cada material, a fim de atingir uma mistura com o mínimo de vazios, e ,consequentemente, maior densidade;

$\checkmark$ A relação água/cimento deve ser mínima, e adotada com muito rigor, baseada em estudos experimentais onde a lei de Abrams não 
é mais aplicável, procurando-se sempre o equilíbrio entre trabalhabilidade e resistência;

$\checkmark$ A idade do concreto influencia as propriedades mecânicas, típico de qualquer material a base de cimento Portland hidratado. O CPR tem comportamento especial, pois apresenta elevada resistência nas primeiras idades, mesmo sem cura térmica;

$\checkmark$ A temperatura de cura é um fator importante para definir as propriedades do concreto de pós reativos, onde temperaturas elevadas de cura proporcionam concretos mais resistentes, principalmente nas primeiras idades;

$\checkmark$ O tempo pré cura térmica também influencia as propriedades do CPR, onde para aumentar a resistência à compressão, recomendase que os modelos sejam colocados em cura térmica após 2 dias de moldados, proporcionando uma maior quantidade de partículas de cimento hidratado, que atuarão durante o tratamento térmico;

$\checkmark \quad O$ tempo de permanência em cura térmica também deve ser estudado para melhorar as propriedades mecânicas do CPR. A maior permanência neste regime de cura proporciona uma aceleração das propriedades mecânicas, o que influencia principalmente os concretos nas primeiras idades. No entanto, esta influência é mais evidente para tempos de cura térmicas até 24 horas;

$\checkmark$ As fibras metálicas mostraram-se um ingrediente muito importante para o CPR, elas atuam no instante do aparecimento das primeiras fissuras, provocando uma redistribuição das tensões internas, promovendo aumento da resistência à compressão e à tração, e, além disso, tornando o material mais dúctil. As fibras apresentam excelente desempenho nas primeiras idades do concreto e, quanto maior a quantidade de fibras, ocorre melhora nas propriedades mecânicas, exceto para a resistência à compressão, onde recomenda-se o limite de $3 \%$ do volume, pois a partir deste, 0 concreto tende a diminuir sua resistência, em virtude da incorporação de vazios por dificuldade de trabalhabilidade e adensamento.

$\checkmark$ O procedimento de mistura dos materiais é um fator que influencia na homogeneidade da mistura, trabalhabilidade do concreto e consequentemente suas propriedades. Recomenda-se que, na falta 
de um agitador eficiente, faça-se a pré misturas dos pós, aplicando uma energia de agitação suficiente para homogeneizar a mistura. $\mathrm{Na}$ sequência, deve-se colocar a água juntamente com 0 superplastificante, e continuar a homogeneizar até que se alcance a trabalhabilidade esperada, só então deve-se adicionar as fibras, e prosseguir com a homogeneização. A moldagem pode ser feita com adensamento mecânico, principalmente quando utilizam-se taxas elevadas de fibras.

$\checkmark$ A cura dos modelos deve se iniciar logo após o término da moldagem, primeiramente com cura úmida e, posteriormente, a cura térmica.

A partir dos resultados dos ensaios de compressão axial e flexão em 4 pontos, pôde-se analisar as propriedades mecânicas do concreto de pós reativo, observando o comportamento da resistência à compressão ao longo do tempo; a influência das fibras na resistência àcompressão; a relação tensão $x$ deformação para o concreto de pós reativos; o módulo de deformação longitudinal; as deformações específicas na compressão; as deformações máximas na tração; a influência das fibras na resistência àtração na flexão; e o comportamento força x deslocamento. Assim, concluiu-se que:

$\checkmark$ O objetivo de desenvolver concreto de pós reativos com resistência àcompressão próxima de 200MPa foi alcançado com êxito;

$\checkmark$ A resistência à compressão se estabilizou a partir dos 28 dias de idade para o concreto sem fibra, já os que continham fibras, a estabilidade na resistência ocorreu aos 7 dias. Onde se comprovou que a adição de fibras, juntamente com a cura térmica, promovem aumento da resistência àcompressão nas primeiras idades;

$\checkmark$ Os ensaios àcompressão axial apresentaram ruptura frágil, mesmo com taxas de fibras de $4 \%$. Já para os ensaios à flexão, as fibras promoveram ductilidade, e o aumento da quantidade de fibras torna o concreto cada vez mais dúctil;

$\checkmark$ As fibras provocaram pequeno crescimento da resistência à compressão, até a taxa de $3 \%$, onde a partir deste ponto, houve decréscimo na resistência;

$\checkmark$ A resistência àtração na flexão variou com a taxa de fibras utilizada, onde os modelos sem fibras tiveram resistência média de $11,83 \mathrm{MPa}$, e os com $4 \%$ de fibras atingiram tensão média de 34,81MPa; 
$\checkmark$ Taxas de fibras a partir de $2 \%$ promoveram maior ductilidade ao material, quando solicitados a flexão pura, sem perdas bruscas de resistência. $O$ aumento da quantidade de fibras também provocou crescimento da resistência à tração na flexão do material, e esse efeito só foi constatado com taxas de fibras a partir de 1\%;

$\checkmark$ As fibras não provocaram interferências significativas nos valores para o módulo de elasticidade que ficaram entre 46,3GPa e 54,6GPa.

$\checkmark$ A deformação específica última que na compressão, foi definida com o valor médio de 4,37\%。. Entretanto, o limite elástico para as deformações de tração, foi de 0,277\%. Essas deformações não sofreram influência significativas com relação a quantidade de fibras;

$\checkmark$ A relação tensão $x$ deformação na compressão apresentou comportamento bilinear. $O$ ponto de transição entre os dois trechos retilíneos, foi definido por um coeficiente de redução da tensão de ruptura, denominado " $\boldsymbol{\alpha}$ ", e este coeficiente foi determinado de acordo com os dados experimentais. A relação entre o módulo de elasticidade do primeiro e segundo trecho foi estabelecida por um coeficiente " $\boldsymbol{\beta}$ ", definido com base nos resultados experimentais;

$\checkmark$ Foi proposta uma relação constitutiva para tensões de compressão, que pode ser utilizada em concreto de pós reativos, com resistência à compressão próximo de $200 \mathrm{MPa}$ e taxa de fibras até $4 \%$ do volume. A relação tensão $x$ deformação proposta, foi representada pelas equações 5.6 e 5.7, e representaram fielmente os resultados experimentais desta pesquisa;

$\boldsymbol{\sigma}=\boldsymbol{\beta} \cdot E \cdot \boldsymbol{\varepsilon}+f_{\mathrm{i}} \cdot(1-\boldsymbol{\beta})$ onde $\begin{cases}\boldsymbol{\beta}=1 & \text { se } \boldsymbol{\sigma} \leq f_{\mathrm{i}} \\ \boldsymbol{\beta}=0,03 \cdot V_{f}+0,8 & \text { se } \boldsymbol{\sigma}>f_{\mathrm{i}}\end{cases}$

$f_{i}=\alpha \cdot f_{c}$

$\alpha=-0,0086 \cdot V_{f}^{4}+0,0988 \cdot V_{f}^{3}-0,3561 \cdot V_{f}^{2}+0,3609 \cdot V_{f}+0,6764$

onde: $\quad f_{i}=$ tensão no ponto de transição;

$f_{c}=$ resistência de ruptura;

$\alpha=$ coeficiente de redução da tensão de ruptura;

$V_{f}=$ taxa de fibras em volume, multiplicada por 100 . 
De acordo com os resultado da análise da porosimetria por intrusão de mercúrio (PIM) e as micrografias (MEV) com EDS realizados nas amostras de concreto de pós reativos, pode-se deduzir que:

$\checkmark$ O CPR é um material com baixíssima porosidade, o que pode conferir alta resistência e durabilidade;

$\checkmark$ Não foi encontrado nos EDS realizados a fase $\mathrm{CH}$ (hidróxido de cálcio), o que pode ser proveniente da alta quantidade de sílica ativa contida na mistura, que reagiu com o $\mathrm{CH}$ e provocou uma maior quantidade de hidróxido de cálcio (C-S-H) na matriz;

$\checkmark$ A microestrutura mostrou-se bem densa, com aparecimento de macro poros decorrentes do ar aprisionado durante a mistura e moldagem dos modelos;

$\checkmark$ A interface entre a pasta e os grãos de areia mostrou-se bem densa, homogênea e coesa;

$\checkmark$ A ligação pasta - fibra também mostrou-se bem definida, com grande concentração de C-S-H;

$\checkmark$ A microestrutura do concreto de pós reativos mostrou-se diferente dos concretos usuais e de alto desempenho, ou seja, muito mais densa e com baixa porosidade, o que confere a este tipo de material altíssimas resistências e durabilidade.

Essas análises fornecem parâmetros importantes para o conhecimento do concreto de pós reativos, quando este for submetido a solicitações normais e de flexão. $E$ os parâmetros definidos neste estudo foram obtidos pela análise de um concreto desenvolvido com tecnologia própria, e materiais disponíveis na região, o que favorece a continuidade da pesquisa com novos estudos sobre aplicações em estruturas em escala real. 


\section{Sugestões para Continuidade da Pesquisa}

Como continuidade desta pesquisa, sugere-se ampliar os estudos já iniciados, a fim de fundamentar os conceitos que regem o concreto de pós reativos, para isso seria necessário:

$\checkmark$ Ampliar os limites de resistência à compressão, realizando estudos com concretos de $150 \mathrm{MPa}$ até $300 \mathrm{MPa}$, e verificar o comportamento desses materiais com a influência de mais esse parâmetro;

$\checkmark$ Estudar a influência da temperatura de cura térmica, nas propriedades mecânicas do concreto de pós reativos, a fim de descobrir quais os fatores modificam suas propriedades, com relação a microestrutura. Além de variar o tipo de cura térmica, com vapor de água e ar seco quente, elevando assim, as temperaturas de cura até os $200^{\circ} \mathrm{C}$;

$\checkmark$ Realizar estudos específicos de durabilidade do material;

$\checkmark$ Estudar a microestrutura do CPR, mais especificamente a influência da temperatura de cura térmica, quantidade sílica ativa e pó de quartzo;

$\checkmark$ Estudar os efeitos da ação de longa duração (fluência) no concreto de pós reativos, pois existem vários fatores do concreto de pós reativos que podem contribuir para o efeito de fluência, como: a ausência de agregado graúdo diminui a contenção da pasta, e pode aumentar a fluência; os grãos de areia fina usados em CPR, tem módulo de elasticidade próximo do módulo da pasta de cimento, o que não deve contribuir na diminuição do efeito da fluência; a grande quantidade de pasta de cimento também pode influenciar no aumento da fluência; a baixa relação água/cimento e a diminuta porosidade, podem ajudar a minimizar o efeito da deformação lenta;

$\checkmark$ Estudar estruturas em escala real, de pequenas espessuras, utilizando o concreto de pós reativos, e analisar o seu comportamento sob ações de esforços normais, de flexão e de cisalhamento. 



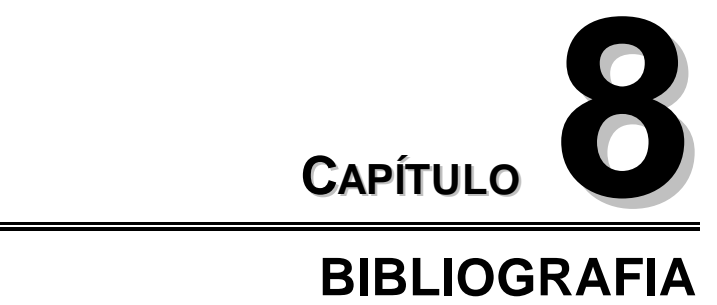




\section{1- Referências Bibliográficas}

AÏ TCIN, P. C. (2000). Concreto de Alto Desempenho. São Paulo: Pini

AITCIN, P. C.; RICHARD, P. (1996). The Pedestrian/Bikeway Bridge of Sherbrooke. In: INTERNATIONAL SYMPOSIUM OF HIGH STRENGTH/HIGH PERFORMANCE CONCRETE, 4., 1996, Paris, France. Anais... Paris. p. 1399-1406.

ADELINE, R.; BEHLOUL, M. (1996). High Ductility Beams Without Passive Reinforcement. In: INTERNATIONAL SYMPOSIUM OF HIGH STRENGTH/HIGH PERFORMANCE CONCRETE, 4., 1996, Paris, France. Anais... Paris. p. 1383-1390.

ANDEREGG, F. O. (1931). Grading Aggregates: II. Ind. Eng. Chem . v. 23, 1931, p. 1058-1064.

ANDREASSEN, A. H. M.; ANDERSEN, J. (1930). Kolloid Z. Ind. Eng. Chem . v. 50, 1930, p. 217-228.

ASSOCIAÇÃO BRASILEIRA DE NORMAS TÉCNICAS. (1983) NBR 7211: Agregados para concreto. Rio de Janeiro.

(1996) NBR 7215: Cimento Portland: Determinação da resistência à compressão. Rio de Janeiro.

(1982) NBR 7251: Agregados em estado solto: determinação da massa unitária. Rio de Janeiro.

. (1987) NBR 9776: Agregados: determinação da massa específica de agregados miúdos por meio do Frasco de Chapman. Rio de Janeiro.

. (1991) NBR 11579: Cimento Portland: Determinação da finura por meio da peneira 75 micrometro (número 200). Rio de Janeiro.

. (1998) NBR NM 76: Cimento Portland: Determinação da finura pelo método de permeabilidade ao ar (Método de Blaine). Rio de Janeiro.

(2002) NBR NM 65: Cimento Portland: Determinação do tempo de pega.

Rio de Janeiro.

BEHLOUL, M.; BERNIER, G.; CHEYREZY, M. (1996). Tensile Behavior of Reactive Powder Concrete (RPC). In: INTERNATIONAL SYMPOSIUM OF HIGH STRENGTH/HIGH PERFORMANCE CONCRETE, 4., 1996, Paris, France. Anais... Paris. p. 1375-1381.

BEHLOUL, M.; ADELINE, R.; BERNIER, G. (1996). Non-linear computation of fiber reinforced micro-concrete structures. In: WORLDWIDE ADVANCES IN STRUCTURAL CONCRETE AND MASONRY STRUCTURES CONGRESS, 1996, New York, USA. Anais... New York: ASCE. p. 518-529. 
BEHLOUL, M. (1995). Définition d'une Loi de Comportement du BPR. In: ANNALES DE L'INSTITUT TECHNIQUE DU BATIMENT ET DES TRAVAUX PUBLICS - ITBTP, 1995. Anais... .n. 532, pp. 122-127.

BONNEAU, O.; POULIN, C.; DUGAT, J.; RICHARD, P.; AITCIN, P. C. (1996). Reactive powder concretes: from theory to practice. Concrete International. v. 18, n. 4, p. 47-49, Apr.

BONNEAU, O.; LACHEMI, M.; DALLAIRE, E.; DUGAT, J.; AITCIN, P. C. (1997). Mechanical properties and durability of two industrial reactive powder concretes. $\mathrm{ACI}$ Materials Journal. v. 94, n. 4, p. 286-290, jul.-aug.

CHEYREZY, M.; MARET, V.; FROUIN, L. (1995). Microstructural Analysis of RPC (Reactive Powder Concrete). Cement and Concrete Research. v. 25, n. 7, p. 14911500 , Oct.

DALLAIRE, E.; AITCIN, P. C.; LACHEMI, M (1998). High-performance powder. Civil Engineering, New York, v. 68, n. 1, p. 48-51, Jan.

DALLAIRE, E.; BONNEAU, O.; LACHEMI, M.; AITCIN, P. C. (1996). Mechanical behavior of confined reactive powder concretes. Materials for the new millennium. In: MATERIALS ENGINEERING CONFERENCE, 1996, New York, USA. Anais... New York: ASCE. v. 1, p. 555-563.

DINGER, D. R.; FUNK, J. E. (1992). Particle packing Part I - Fundamentals of particle packing monodisperse spheres. Interceram, v. 41, n. 1, p. 10-14.

DINGER, D. R.; FUNK, J. E. (1993). Particle packing IV - Computer Modelling of particle packing phenomena. Interceram, v. 42, n. 3, p. 150-152.

DOWD, W. M.; O'NEIL, E. F. (1996). Development of reactive powder concrete (RPC) precast products for the USA market. In: INTERNATIONAL SYMPOSIUM OF HIGH STRENGTH/HIGH PERFORMANCE CONCRETE, 4, 1996, Paris, France. Anais... Paris. p. 1391-1398.

DUGAT, J.; ROUX, N.; BERNIER, G. (1995). Étude Expérimentale de la Déformation sous Contrainte et du Comportement àla Rupture du Béton de Poudres Réactives. In: ANNALES DE L'INSTITUT TECHNIQUE DU BATIMENT ET DES TRAVAUX PUBLICS - ITBTP, 1995. Anais... .n. 532, p. 112-121.

FURNAS, C. C. (1931). Grading Aggregates: I. Ind. Eng. Chem , v. 23, p. 1052-1058.

LI, V. C. (1992). Postcrack scaling relations for fiber reinforced cementitious composites. Journal of Materials in Civil Engineering, v. 4, n 1, p. 41-57.

MEHTA, P. K.; MONTEIRO, P. J. M (1994). Concreto: estrutura, propriedades e materiais. São Paulo: Pini. 
MELO, A. B. (2000). Influência da cura térmica (vapor) sob pressão atmosférica no desenvolvimento da microestrutura dos concretos de cimento Portland. São Carlos: Interunidade EESC, IFSC, IQSC. Tese (Doutorado). USP. São Carlos. 1999.

MYHRE, B.; HUNDERE, A. M. (1996) The use of particle size distribution in development of refractory castables. In: XXV ALAFAR CONGRESS, 1996, San Carlos de Bariloche, Argentina. Anais... San Carlos de Bariloche.

NAAMAN, A. E.; REINHADT, H. W.; FRITZ, C.; ALAWAN, J. (1993). Non-linear analysis of RC beams using a SIFCON matrix. Materials and structures. v. 26, n. 7, p. $522-531$.

NEVILLE, A. M. (1997). Propriedades do Concreto. $2^{a}$. ed. São Paulo: Pini.

PHILIPPOT, S.; MASSE, S.; ZANNI, H.; NIETO, P.; MARET, V.; CHEYREZY, M. (1996). ${ }^{29} \mathrm{Si}$ NMR Study of hydration and pozzolanic reaction in reactive powder concrete (RPC). Magnetic Resonance Imaging. v. 14, n. 7/8, p. 891-893.

RICHARD, P. (1996). Reactive powder concrete: A new ultra-high-strength cementitious material. In: INTERNATIONAL SYMPOSIUM OF HIGH STRENGTH/HIGH PERFORMANCE CONCRETE, 4, 1996, Paris, France. Anais... Paris. p. 1343-1349.

RICHARD, P.; CHEYREZY, M. (1994). Reactive Powder Concretes with High Ductility and 200-800MPa Compressive Strength. Concrete Technology Past, Present, and Future. In: V. MOHAN MALHOTRA SYMPOSIUM, ACI SPRING CONVENTION, SP 144-24, 1994. Anais... p. 507-518.

RICHARD, P.; CHEYREZY, M. (1995). Composition of reactive powder concretes. Cement and Concrete Research. v. 25, n. 7, p. 1501-1511, Oct.

RICHARD, P.; CHEYREZY, M. (1995b). Les Béntons de Poudres Réactives. In: ANNALES DE L'INSTITUT TECHNIQUE DU BATIMENT ET DES TRAVAUX PUBLICS - ITBTP, 1995. Anais... .n. 532, p. 85-102.

ROUX, N.; ANDRADE, C.; SANJUAN, M. A. (1995). Éstude Expérimentale sur la Durabilité de $s$ Bétons de Poudres Réactives. In: ANNALES DE L'INSTITUT TECHNIQUE DU BATIMENT ET DES TRAVAUX PUBLICS - ITBTP, 1995. Anais... n. 532, p. 133-141.

SILVA, I. J. (2000). Contribuição ao estudo dos concretos de elevado desempenho: propriedades mecânicas, durabilidade e microestrutura. São Carlos: Interunidade EESC, IFSC, IQSC. Tese (Doutorado). USP. São Carlos, 2000.

TAYLOR, H.F.W.; NEWBURY, D.E. (1984). An electron microprobe study of a mature cement paste. Cement and Concrete Research, v.14, p.565-73. 
TORRENTI, J. M.; MATTE, V.; MARET, V.; RICHET, C. (1996). High integrity containers for interim storage of nuclear wastes using reactive powder concrete. In: INTERNATIONAL SYMPOSIUM OF HIGH STRENGTH/HIGH PERFORMANCE CONCRETE, 4, 1996, Paris, France. Anais... Paris. p. 1407-1413.

VESTERGAARD, C. N. (1991). Tensile post-crack behavior of steel fiber reinforced ultra high-strength concrete. Bangkok proceedings, 21 Nov.

ZANNI, H.; CHEYREZY, M.; MARET, V.; PHILIPPOT, S.; NIETO, P. (1996). Investigation of Hydration and Pozzolanic Reaction in Reactive Powder Concrete (RPC) Using ${ }^{29}$ Si NMR. Cement and Concrete Research, v. 26, n. 1, p. 93-100.

WASSERMAN, R.; BENTUR, A. (1996) Interfacial interactions in lightweight aggregate concretes and their influence on the concrete strength. Cement and Concrete Composites, v.18, p. 67-76.

WHITTMORE, C. J.; HALSEY, G. D. (1983). Pore structure characterization by mercury porosimetry. In: Advances in Materials Characterization. New York: Ed. David, R.; Rossington, R.; Condrate, C. A.; Snyder, R. L., Plenum Publishing Corporation, p. 147-157. 


\section{2- Bibliografia Complementar}

ASSOCIAÇÃO BRASILEIRA DE NORMAS TÉCNICAS. (2002) NBR 6023: Informação e documentação referências: elaboração. Rio de Janeiro.

. (1989) NBR 6027: Sumário. Rio de Janeiro.

(1990) NBR 6024: Numeração progressiva das seções de um documento.

Rio de Janeiro.

. (1990) NBR 6028: Resumos. Rio de Janeiro.

(1992) NBR 10520: Informação e documentação: trabalhos acadêmicos: apresentação. Rio de Janeiro.

. (1989) NBR 6027: Sumário. Rio de Janeiro.

BINA, P. (1999) Concretos de pós reativos: uma revolução no conceito do concreto. Téchne, São Paulo: PINI, n.38, p. 50-51, jan. - fev.

BIRELLI, G.; DUGAT, J.; BEKAERT, A. (1998). The use of rpc in cross-flow cooling towers. In: INTERNATIONAL SYMPOSIUM ON HIGH-PERFORMANCE AND REACTIVE POWDER CONCRETE, 1998, Sherbrooke, Québec, Canada. Anais... Sherbrooke, v. 3, p. 59-73, Aug.

CHAUVEL, D.; ADELINE, R.; JACQUEMMOZ, C.; BIRELLI, G. (1998). First design rules for rpc beams. In: INTERNATIONAL SYMPOSIUM ON HIGH-PERFORMANCE AND REACTIVE POWDER CONCRETE, 1998, Sherbrooke, Québec, Canada. Anais... Sherbrooke, v. 3, p. 1-15, Aug.

CHEYREZY, M. (1999). Structural applications of RPC. Concrete, London, v. 33, n. 1, p. 20-23, Jan.

CHEYREZY, M.; MARET, V.; FROUIN, L. (1995). Analyse de la microsructure du béton de poudres réactives (BPR). In: ANNALES DE L'INSTITUT TECHNIQUE DU BATIMENT ET DES TRAVAUX PUBLICS - ITBTP, 1995. Anais... .n. 532, p. 103-111. DUGAT, J.; FROUIN, L.; CLAVAUD, B. (1996). RPC: Microstructure analysis. In: INTERNATIONAL SYMPOSIUM OF HIGH STRENGTH/HIGH PERFORMANCE CONCRETE, 4, 1996, Paris, France. Anais... Paris. p. 1351-1357.

FEYLESSOUFI, A; CRESPIN, M; DION, P; BERGAYA, F; VANDAMME, H; RICHARD, P. (1997). Controlled rate thermal treatment of reactive powder concretes. Advanced Cement Based Materials, v. 6, p. 21-27, Jun.

FEYLESSOUFI, A.; VILLIERAS, F.; MICHOT, L. J.; DE DONATO, P.; CASES, J. M.; RICHARD, P. (1996). Water environmental and nanostructural network in a reactive powder concrete. Cement and Concrete Composites, v. 18, n. 1, p. 23-29. 
FUSCO, P. B. (1989). O Cálculo de Concreto Armado em Regime de Ruptura. In: SIMPÓSIO EPUSP SOBRE ESTRUTURAS DE CONCRETO, 1989, São Paulo. Anais... São Paulo, USP. v. 1, p. 241-289.

FUNK, J. E.; DINGER, D. R. (1992). Particle packing II - Review of packing of polydisperse particle systems. Interceram. v. 41, n. 2, p. 95-97.

(1992). Particle packing III - Discrete versus continuous particle sizes. Interceram. v. 41, n. 5, p. 332-334.

(1994). Particle packing $\mathrm{V}-$ Computational methods applied to experimental distributions. Interceram. v. 43, n. 2, p. 87-89.

(1994). Particle packing V - Computational methods applied to experimental distributions (continued). Interceram. v. 43, n. 3, p. 150-154.

(1994). Particle packing VI - Applications of particle size distribution concepts. Interceram. v. 43, n. 5, p. 350-353.

GILLILAND, S. K. (1996). Reactive powder concrete (RPC), a new material for prestressed concrete bridge girders. In: BUILDING AN INTERNATIONAL COMMUNITY OF STRUCTURAL ENGINEERS STRUCTURES CONGRESS, 1996, New York, USA. Anais... New York: ASCE. v. 1, p. 125-132.

LARRARD, F. (1989). Ultrafine particles for the making of very high strength concretes. Cement and Concrete Research. v. 19, p. 161-172.

LARRARD, F. (1990). A method for proportioning high-strength concrete mixtures. Cement, Concrete, and Aggregates, CCAGDP - ASTM. v. 12, n. 2, p. 47-52.

LARRARD, F.; TONDAT, P. (1993). Sur la contribution de la topologie du squelette granulaire àla résistance en compression du béton. Materials and Structures, v. 26, p. 505-516.

LARRARD, F.; SEDRAN, T. (1994). Optimization of ultra-high-performance concrete by the use of a packing model. Cement and Concrete Research, v. 24, n. 6, p. 997-1009.

MATTE, V.; MORANVILLE, M. (1999). Durability of reactive powder composites: influence of silica fume on the leaching properties of very low water/binder pastes. Cement and Concrete Composites, v. 21, p. 1-9.

ROSSIGNOLO, J. A. (2003). Concreto leve de alto desempenho modificado com SB para pré-fabricados esbeltos - dosagem, produção, propriedades e microestrutura. São Carlos: Interunidade EESC, IFSC, IQSC. Tese (Doutorado). USP. São Carlos, 2003.

ROUX, N.; BARRANCO, M. (1995). Mise en oeuvre des bétons de poudres réactives (BPR) dans le BTP. In: ANNALES DE L'INSTITUT TECHNIQUE DU BATIMENT ET DES TRAVAUX PUBLICS - ITBTP, 1995. Anais... .n. 532, p. 128-132. 
ROUX, N.; ANDRADE, C.; SANJUAN, M. A. (1996). Experimental study of durability of reactive powder concretes. Journal of Materials in Civil Engineering, v. 8, n. 1, p. 1-6, Feb.

$\mathrm{RÜSCH}$, H. (1960). Researches toward a general flexural theory for structural concrete. Journal of the American Concrete Institute. jul.

SALVADOR FILHO, J. A. A.; BARBOSA, M. P. (2000). Análise das propriedades mecânicas do concreto de alto desempenho submetido à cura térmica. In: CONGRESSO BRASILEIRO DO CONCRETO, 42, 2000, Fortaleza, Ceará, Brasil. Anais... Fortaleza: IBRACON. 1 CD-ROM.

SARKAR, S. L.; AITCIN, P.C.; DJELLOULI, H. (1990). Synergistic roles of slag and silica fume in very high-strength concrete. Cement, Concrete and Aggregates, v.12, n.1, p.800-808.

SAUZEAT, E.; FEYLESSOUFI, A.; VILLIÉRAS, F.; YVON, J.; CASES, J. M.; RICHARD, P. (1996). Textural analysis of reactive powder concretes. In: INTERNATIONAL SYMPOSIUM OF HIGH STRENGTH/HIGH PERFORMANCE CONCRETE, 4, 1996, Paris, France. Anais... Paris. p. 1359-1365.

VANDERLEI, R. D.; GIONGO, J. S. (2000). Concreto composto de pós reativos: características e aplicações. In: CONGRESSO BRASILEIRO DO CONCRETO, 42, 2000, Fortaleza, Ceará, Brasil. Anais... Fortaleza: IBRACON, 1 CD-ROM.

UZAWA, M.; MASUDA, T.; SHIRAI, K.; SHIMOYAMA, Y.; TANAKA, Y. (2002). Fresh mortar properties and strength of reactive powder composite material (Ductal ${ }^{\circledR}$ ). In: FIB CONGRESS, 1, 2002, Osaka, Japan. Anais... Osaka: FIB. P. 127-132.

VANDERLEI, R. D. (1999). Análise experimental de pilares de concreto armado de alta resistência sob flexo compressão reta. Dissertação (Mestrado) - Escola de Engenharia de São Carlos - Universidade de São Paulo, São Carlos. 1999.

WALRAVEN, J. C. (2002). Concrete for a new century. In: FIB CONGRESS, 1, 2002, Osaka, Japan. Anais... Osaka: FIB. P. 11-22. 